Universidad Nacional de La Plata

Facultad de Humanidades y

Ciencias de la Educación

Secretaría de Posgrado

\title{
La educación como patrón de diseño para estudios histórico-sociales. \\ Estudios comparativos e identidades urbanas del Sudoeste Bonaerense (1779-1875)
}

Lic. Marta Susana Ramírez

Tesis para optar por el grado de Doctor en Historia

Director: Doctor Fernando Enrique Barba - UNLP 


\section{Agradecimientos}

Esta tesis es la conclusión de más de treinta años que comencé a e studiar las diferentes políticas educativas de la Argentina y de América Latina, cuando guiada por el profesor Félix Weinberg, en la Universidad Nacional del Sur, me llevó a la comprensión que la educación de un país es la columna vertebral que sostiene como en el ser humano, el cuerpo de una república. Por eso, este trabajo está dirigido a honrar su memoria.

Igualmente al doctor Fernando Barba, de la Universidad Nacional de La Plata quien me orientó desde un primer momento con bonhomía y paciencia frente a mis dudas y necesarias correcciones. Fue la certera respuesta académica frente a mis dudas y la meticulosa mirada de quienes sin decirlo son sabios en sus apreciaciones, pero humildes en sus presentaciones. Y a la doctora Rosario Guenaga quien me orientó durante los primeros años como codirectora de tesis en la Universidad Nacional del Sur hasta su traslado a centros académicos de Buenos Aires.

Mi agradecimiento especial al doctor Hernán Asdrúbal Silva con quien compartí horas de trabajo en el gabinete de Historia Argentina y Americana facilitándome material bibliográfico y a mis alumnos de la Universidad Nacional del Sur.

A la Doctora Nidia Burgos, amiga y colega, quien me alentó para concluir este trabajo y a Alejandro Banegas de Ediuns (Editorial de la Universidad Nacional del Sur) por hacer posible que lo concretara.

Esta tesis no podría haberse concretado la invalorable ayuda de la doctora Ana Luisa Dozo, directora del Museo Histórico de Bahía Blanca y del Archivo Histórico Municipal; al personal y directivos del Archivo Histórico de Carmen de Patagones y a la calidez del personal del Archivo Histórico de la provincia de Buenos Aires «Doctor Ricardo Levene» de La Plata y del Archivo General de la Nación.

Mi homenaje a mis padres Raúl y Amalia que me alentaron en mis estudios. También agradezco a mis hermanas Cristina y María Luisa y a mis amadas hijas Romina, Agustina y Josefina quienes me acompañaron en mi tarea, restando horas a ellos. Y a mis nietos, para que este sea el legado que pueda dejarle de horas de investigación y estudio. 


\section{Índice}

$\begin{array}{ll}\text { Resumen } & 7\end{array}$

Introducción 99

1. Concepto de la educación desde fines del siglo XVIII hasta 1875

2. Fundamentación y metodología 12

2.1. Objetivos 12

2.2. Hipótesis 12

3. Metodología 13

4. Algunos enfoques historiográficos sobre la educación argentina 15

5. Estado general de la cuestión 17

Primera Parte: Rupturas y continuidades culturales y educativas en el sudoeste bonaerense: del fin del Régimen a la consolidación del modelo rivadaviano

Capítulo 1: Representaciones culturales y educativas. Diversidades entre Patagones y la Fortaleza Protectora Argentina

1. Parámetros históricos fundacionales y dimensiones culturales de la ciudad del Carmen y de la Fortaleza Protectora Argentina (1779-128)

2. Carmen de Patagones. La palabra de los fundadores y primeros colonizadores 25

3. La estadística como criterio de análisis metodológico 28

4. Patagones como espacio de aislamiento 37

5. La Fortaleza Protectora Argentina (1828) 43

5.1. La frontera como expansión como espacios de comunicación interétnica 43

5.2. Las expediciones previas a la fundación de la Fortaleza 47 
5.3. Los indios amigos

5.4. La Fortaleza Protectora Argentina según el discurso de sus fundadores

5.5. El puerto: su creación y la educación de los artilleros

5.6. Estomba y la educación de los fundadores

5.7. La comisaría como antecedente de la justicia de paz en la Fortaleza Protectora Argentina

5.8. La vecindad y la fundación

6. Quiebres y continuidades de las mentalidades educativas de la etapa colonial al gobierno independiente (1779-1821)

6.1. Análisis y relación de esquemas teóricos sobre el Iluminismo en el Río de la Plata

6.3. Alternativas educacionales en el período de transición: de la propuesta rivadaviana a la rosista (1821-1852)

6.4. Análisis discursivo del Reglamento de Escuelas de Primeras Letras de Carmen de Patagones

6.5. El rosismo y su compromiso educativo en la visión de testigos e historiadores

6.6. Nuevos códigos de la política educativa rosista

Capítulo 2: La educación como determinante socio-cultural en la ocupación de la frontera del sudoeste bonaerense

1. Militarización y educación en la Ciudad del Carmen

1.1. Los blandengues y dragones

Conclusiones parciales

2. Militarización y educación en Bahía Blanca

3. Darwin: la mirada del naturalista sobre la milicia de Bahía Blanca

Conclusiones parciales

4. Los comandantes de frontera y su incidencia en la educación. Vínculos con maestros y vecinos

4.1. Coronel José Gabriel de la Oyuela

4.2. Comandante Martín Paulino Lacarra y Toledo

4.3. Comandante Francisco Crespo

4.4. Los comandantes de la transición (1829-1855)

4.5. Comandante Julián Murga

5. La mujer como «intermediaria cultural» de dos mundos: masculinidad o femineidad

5.1. Dimensiones culturales del saber femenino

5.2. Grupos de pertenencia de las mujeres de frontera

5.3. La mujer educada y las cautivas en la Fortaleza Protectora Argentina 
6. Premios y lecturas de las escuelas de mujeres de la frontera

7. El educador masculino. Estrategias de adaptación a nuevos espacios. Reacción frente a la incertidumbre

7.1. Redes familiares

7.2. Prácticas pedagógicas y política educacional en las escuelas de varones

8. Justicia de Paz: prácticas jurídicas y educativas

8.1. El sumario como fuente de indagación educativa

8.2. El saber como instrumento de construcción de orden y poder

9. Los curas vicarios castrenses

Conclusión parcial

Apéndice $n .^{\circ} 1$

Apéndice $n .{ }^{\circ} 2$

Apéndice $n .^{\circ} 3$

Apéndice $n .^{\circ} 4$

Apéndice $n .^{\circ} 5$

Apéndice $n .^{\circ} 6$

\section{Segunda Parte: Articulación entre el modelo educativo conservador y el constitucionalismo liberal del estado bonaerense}

Capítulo 3: Reformulación del sistema educativo bonaerense (1852-1871)

1.a. La búsqueda de un plan de homogeneidad educativa

1.b. La Constitución del estado de Buenos Aires

1.c. Cambios estructurales de la educación bonaerense (1853-1871)

1.d. Concreción de las ideas de la Generación del 37

2. El Plan Combinado de Educación Común de Sarmiento y su aplicabilidad a la realidad socio-económica del Estado de Buenos Aires

3. La frontera sudoeste: progreso y educación en la mirada de Sarmiento

4. El texto escolar como primera aproximación a la lectura en escuelas de frontera

5. Identidad y convenciones teatrales de las fiestas mayas y julias

6. Edificios escolares, suscripciones y vecindad 
2. Censos de 1869: parámetros de comparación de dimensiones educativas en el sudoeste bonaerense

Conclusión

Bibliografía

Fuentes documentales

Fuentes éditas

Bibliografía específica

Bibliografía general 


\section{Resumen}

El análisis de los diferentes fundamentos político ideológicos son traducidos a su vez en modificaciones en los modelos educativos y prácticas pedagógicas que tuvieron su aplicación en Buenos Aires y la región noroeste y noreste región circundante a la frontera indígena. Ello permite suponer similares procesos en el sur del territorio bonaerense.

Esta tesis doctoral, se ubica en un espacio geográfico diferente como fueron los dos centros urbanos más lejanos de la frontera Sur, la Ciudad del Carmen de Patagones y la Frontera Protectora Argentina, entre 1779 y 1875 , con la promulgación de la Ley de Educación Común de la provincia de Buenos Aires.

El objetivo es indagar y contrastar — desde la fundación de ambos espacios de frontera- la construcción de una cultura con conocimientos pragmáticos compartidos, en cuanto a la relación con la autoridad central según el grado de alfabetización o escolarización; la relación de los educadores con la sociedad y de peculiaridades diferenciales y vínculos entre ambas comarcas.

Podemos encontrar como el acceso a la educación sistematizada en sociedades rurales generó que diferentes actores como los comandantes de frontera, los miembros de las guardias nacionales o del ejército de campaña, los jueces de paz, los curas vicarios castrenses, los educadores masculinos y las mujeres, relacionado con el dominio de saberes que favorecieron la construcción de estamentos sociales ligados al poder político y al acceso a la propiedad.

El acceso a la educación sistematizada a partir de 1852, el surgimiento del estado de Buenos Aires y la creación de la Jefatura de Escuelas del estado de Buenos Aires a cargo de Domingo Faustino Sarmiento, genera un proceso de paulatina urbanización con apoyo a la inmigración — fundamentalmente italianaen la región del Sudoeste como respuesta a un modelo educativo ideado por los hombres de la Generación del 37. Existe, a partir de este momento, una reorientación seria hacia la educación primaria y popular con nuevos instrumentos legales y estadísticos. 
Nuevas formulaciones y prácticas educativas que se instruyen a partir de la década del 50 del siglo XIX, nos permite distinguir como la educación es una forma de estudio de una sociedad enclavada en un micro-espacio y de diferenciación sub-regional entre Bahía Blanca y Carmen de Patagones.

Palabras claves: Historia de la Educación. Variable de análisis social. Frontera del Sudoeste de la Provincia de Buenos Aires. 


\section{Introducción}

\section{Concepto de la educación desde fines del siglo XVIII hasta $\mathbf{1 8 7 5}$}

Desde la conquista del Rio de la Plata, la educación no constituía para España un problema atinente a la Corona. Por el contrario, la misma estaba delegada casi en su totalidad a las Órdenes Religiosas que acompañaron el proceso de colonización territorial o instituciones para niños desvalidos o expósitos, cuya última finalidad no estaba en la alfabetización. En el contexto histórico a analizar se caracteriza por tres quiebres - ante la permanencia y continuidades - en las mentalidades educativas con propuestas disimiles a las prácticas de instrucción, como principal objetivo la emancipación del hombre ${ }^{1}$. Somos cautelosos de no utilizar épocas o etapas, por cuanto en una explicación teleológica, podemos observar y relacionar la supervivencia de valores y fenómenos que se desarrollan que están relacionadas con la preeminencia de ideas, que no caen abruptamente al abismo, sino que mantienen muchas veces su continuidad.

La primera de ellas, la que se inicia a partir del siglo XVIII con la Borbones en España y que estuvo acompañada, en especial durante el reinado de Carlos III de una evidente sacralización de los órganos educativos. La influencia del padre Feijoó y los ministros de la Corte como Cabarrús, el Conde de Floridablanca y Campomanes, fueron decisivas en el diseño de una educación, no solo para los estratos sociales altos, sino para pequeños labradores, artesanos o el cura párroco de aplicación directa a su

${ }^{1}$ Utilizamos la palabra «instrucción»en una pretensión cronológica a fin de de limitar su alcance a los principios ideológicos de una época sostenidos por la ilustración. «Ya es más fácil que el público se ilustre por sí mismo y hasta, si se le deja en libertad, casi inevitable». Kant, E. ¿Qué es la ilustración?, [s/l]: FCE, 1941. Jorge Gelman (diciembre 2005) sostendrá que tanto discursos como prácticas tendrán un impacto considerable en el Río de la Plata en la aplicación del conocimiento técnico de la mano de funcionarios de experiencia metropolitana, Historia Agraria. 37, págs. 467-488. 
realidad cotidiana ${ }^{2}$. En el Río de la Plata, Manuel Belgrano recoge e impulsa estos principios desde la secretaría del Consulado, diseñando un plan integral de educación y difunde su ideario a través del Correo de Comercio. Mariano Moreno, fundamentalmente a través de La Gaceta, también revalidará el valor de la educación como derecho, sabiendo que para consolidar el régimen revolucionario era necesario formar conciencia en el pueblo e ilustrarlo ${ }^{3}$. La propuesta kantiana de 1784, y los pensadores que continuaron este modelo, queda resumida en la frase: «la ilustración es la liberación del hombre de su culpable incapacidad». Esta incapacidad era la que impedía al hombre moverse sin la ayuda de otro. Instruir era el motor e impulso de los hijos de españoles, que pertenecientes a la alta burguesía porteña o a grandes comerciantes, lograran la prosecución de sus estudios en las universidades europeas o en Charchas y Córdoba en el Río de la Plata. Al igual, quienes integrarían los cuerpos militares superiores, oficiales o plana mayor, ingresaban como cadetes con la condición de ser descendientes de nobles o hijos de oficial no menor al grado de capitán, recibiendo conocimientos de aritmética, geometría y fortificación ${ }^{4}$. Historiadores como Juan Carlos Garavaglia, Fradkin, Canedo y Salvatore, han construido últimamente nuevos enfoques interpretativos en cuanto a la formación de estructuras del poder de las milicias. Aspecto éste último que será tratado oportunamente ${ }^{5}$ Esta situación se tradujo en instituciones de beneficencia y cultura, acentuando el desequilibrio de modelo educativo borbónico. Por todo ello, en la primera parte resulta necesario realizar establecer bajo el método nomológico deductivo, explicación teleológica, que nos permitan comprender cuáles fueron las causas que determinaron la fundación de la ciudad del Carmen de Patagones, en cuanto a las peculiaridades que guarda como espacio de abandono de sus colonos, y destierro en la etapa revolucionaria de la revolución de Mayo. Posteriormente, comprender los parámetros socio-culturales de esta población y su aparente abandono por el gobierno central después de 1810 y los efectos que estos produjeron. En cuanto a Bahía Blanca, cuáles fueron los condicionantes de la creación de esta fortaleza y las vinculaciones y conexiones educativas y socio-culturales que sostiene con Patagones. Paralelamente realizaremos una aproximación al marco teórico- filosófico en lo educacional pretendido por el nuevo gobierno de Buenos Aires y la praxis en la frontera.

${ }^{2}$ Los grupos españoles más ilustrados comenzaron a alentar la necesidad de la educación como derecho natural del hombre. Tribuna de estos reclamos fue la prensa española donde se debatieron diferentes proyectos dispares en sus métodos.

${ }^{3}$ Ramírez, M. S. Aspectos económicos vinculantes entre el Iluminismo Hispánico y el Ideario criollo. Arquetipo: Manuel Belgrano, Comunicación presentada en el Segundo Congreso Nacional Belgraniano, junio de 1994, Buenos Aires, Instituto Nacional Belgraniano, inédito.

${ }^{4}$ Nellar Fued, G.; Pfister, A. y otros Reseña histórica geográfica del Ejército Argentino, Círculo militar, 1972, pág. 78.

${ }^{5}$ Garavaglia, J. C. Construir el estado, inventor la nación. El Río de la Plata, siglos XVIII-XIX, Buenos Aires: Prometeo, 2007; Fradkin, R. y Gelman, J. «Recorridos y desafíos de una historiografía. Escalas de observación y fuentes en la historia rural rioplatense», en: Bragoni, B. (ed.). Micronoanális, Ensayos de historiografía argentina. Buenos Aires: Prometeo, 2004; Salvatore, R. «El mercado del trabajo en la campaña bonaerense (1820-1860). Ocho inferencias a partir de narrativas federales», en: Bonaudo M. y Pucciarelli, A. La problemática agraria. Nuevas aproximaciones. I. Buenos Aires: CEAL, 1993, págs. 59-92. 
El segundo de estos quiebres en las mentalidades, se inicia con la Bernardino Rivadavia (1821-1827) y Juan Manuel de Rosas (1829-1852), con planteos educacionales antagónicos, pero que en determinados momentos - desde el punto de vista institucional - conviven en sí mismos. En esta etapa, en el territorio bonaerense, y dada la política de avance fronterizo, toman relevancia como educadores los jueces de paz, los comandantes de frontera, los oficiales o cargos de mayor rango en las milicias, los curas vicarios del ejército y las mujeres de los primeros.

El tercer quiebre, en esta investigación científica, comprende los fenómenos que ocurren con la aparición de la figura de Domingo Faustino Sarmiento y las motivaciones que impulsan sus reformas en la construcción de una ciudadanía, la fuerte incidencia de la inmigración europea, el diseño de un cuerpo legal educativo que contenga en este nuevo orden de país.

La culminación de esta tesis, está en la comprobación estadística y la aplicabilidad de la ley en un espacio determinado, la frontera del Sudoeste Bonaerense. Pretendemos, de acuerdo al título del trabajo, usar la educación como variable de estudio socio-cultural, en uno de los ámbitos menos explorados por los historiadores, en su marco hermenéutico. Como gran parte de estos estudios, han estado centrados fundamentalmente, en la ciudad de Buenos Aires, comprobamos - como teóricamente lo demuestra en México colonial Van Young ${ }^{6}$ - las variables socio-económicas que determinan la diversidad y la relación entre lo geográfico y sus factores sociales.

En la primera parte, resulta necesario realizar brevemente la introducción sobre los parámetros fundacionales de la Ciudad del Carmen, en cuanto a las peculiaridades que guarda como espacio de abandono de sus colonos, y destierro en la etapa revolucionaria de la revolución de Mayo. Paralelamente realizaremos una aproximación al marco teórico- filosófico en lo educacional pretendido por el nuevo gobierno de Buenos Aires y la praxis en la frontera. La etapa que la precede, parece silenciar la actividad cultural de este espacio, hasta llegar al gobierno de Bernardino Rivadavia y con posterioridad la acción concreta del Juan Manuel de Rosas en este territorio, donde parecen confundirse dos paradigmas educativos que hasta ahora parecían opuestos. Pretenderemos dar un nuevo criterio para determinar cuando comienzan o terminan las alternativas educacionales y su concordancia con la política educativa oficial, y aquellos conceptos ordenadores que integran el contexto de una zona expuesta permanentemente al avance del indígena: el cura vicario castrense, la militarización de los núcleos urbanos, la justicia de paz, se convierten junto a los educadores en sujetos pedagógicos ${ }^{7}$.

\footnotetext{
${ }^{6}$ Van Young, E. «Mexican Rural History since Chevalier: the historiography of the colonial hacienda», Latin American Research Review, 18:3, 1983, págs. 5-61.

${ }^{7}$ Puiggrós, A. «Sujetos, disciplina y curriculum en los orígenes del sistema educativo argentino (1885-1916)», en: Historia de la Educación Argentina, Buenos Aires: Galerna, [s/f], pág. 29.
} 


\section{Fundamentación y metodología}

\subsection{Objetivos}

1. Identificar los parámetros histórico-fundacionales (causas de su fundación, vínculos iniciales culturales y políticas con fracciones dominantes nacionales) y las dimensiones culturales asociadas a factores geográfico-espaciales (distancia del poder central, grado de comunicación interurbano) que le dieron identidad a cada centro urbano.

2. Correlacionar el acceso al conocimiento y a los saberes de determinados actores (Comandantes de frontera, jueces de paz, curas, e indígenas), y conformación de una clase dirigente, en la etapa previa a la sistematización de la educación bonaerense.

3. Establecer las modificaciones en la estructura socio-cultural de acuerdo a la tasa de alfabetización y población escolarizada vinculado a diferentes procesos ideológicos que surgen en el país.

4. Analizar cuáles fueron esos resultados propios que arrojó la política educativa del gobierno central desde su oferta teórica y la praxis posible en estos dos centros urbanos fronterizos En la primera parte, resulta necesario realizar brevemente la introducción sobre los parámetros fundacionales de la Ciudad del Carmen, en cuanto a las peculiaridades que guarda como espacio de abandono de sus colonos, y destierro en la etapa revolucionaria de la Revolución de Mayo. Paralelamente realizaremos una aproximación al marco teórico-filosófico en lo educacional pretendido por el nuevo gobierno de Buenos Aires y la praxis en la frontera. La etapa que la precede, parece silenciar la actividad cultural de este espacio, hasta llegar al gobierno de Bernardino Rivadavia y con posterioridad la acción concreta del Juan Manuel de Rosas en este territorio, donde parecen confundirse dos paradigmas educativos que hasta ahora parecían opuestos. Pretenderemos dar un nuevo criterio para determinar cuando comienzan o terminan las alternativas educacionales y su concordancia con la política educativa oficial, y aquellos conceptos ordenadores que integran el contexto de una zona expuesta permanentemente al avance del indígena: el cura vicario castrense, la militarización de los núcleos urbanos, la justicia de paz, se convierten junto a los educadores en sujetos pedagógicos ${ }^{8}$.

\subsection{Hipótesis}

Como hipótesis fundamental del trabajo, planteamos que los cambios en la región sudoeste del territorio se cristalizaron en resultados absolutamente peculiares y diferentes al resto del estado bonaerense. Tomamos cómo parámetros de análisis las localidades de Carmen de Patagones y Bahía

\footnotetext{
${ }^{8}$ Puiggrós, A. «Sujetos, disciplina y currículum en los orígenes del sistema educativo argentino (1885-1916)», en: Historia de la Educación Argentina, Buenos Aires: Galerna, pág. 29.
} 
Blanca, tratando de verificar si los resultados de aplicación de las políticas educativas diferían, y si esto se producía, qué factores actuaron sobre ellos. Profundizamos en la vinculación entre educador formal o no y pequeña burguesía de intelectuales locales, con los diferentes estamentos sociales propios de esta región, utilizando un concepto gramsciano9 .

La suposición de la existencia de prácticas educativas diferentes, descansa en el hecho que, al ser zona de frontera durante el período indicado, el proceso educativo fue mediado por la justicia de paz y la oficialidad del ejército de frontera, que formó aquí organismos educacionales o culturales, que les confirieron prestigio.

La culminación de esta tesis, está en la comprobación estadística y la aplicabilidad de la ley en un espacio determinado, la frontera del sudoeste bonaerense. Pretendemos, de acuerdo al título del trabajo, usar la educación como variable de estudio socio-cultural, en uno de los ámbitos menos explorados por los historiadores, en su marco hermenéutico, en razón que gran parte de estos estudios, han estado centrados fundamentalmente en la ciudad de Buenos Aires o localidades que constituían el primer eje fronterizo.

Iniciando con los estudios socio- culturales, la variable básica en su elaboración está dada, a nuestro entender, en los diferentes niveles educativos, de comprensión lingüística o de comunicación verbal y escrita de los actores de una sociedad. No obstante existen una conjunción de factores que demuestran las diferencias entre el norte, centro y sur del territorio bonaerense. Este último, en un contexto económico y social de tierras escasas para la agricultura, grandes extensiones de tierra inhabitadas, autoridades fronterizas con mayor independencia del poder central que aumentaba su autonomía y graduaba su status.

\section{Metodología}

Hacia la década del setenta del siglo pasado, nuevos aportes teóricos-metodológicos surgidos de planteos epistemológicos históricos que exigen la articulación de la teoría con la práctica. Y es en este caso que distinguimos desde una mirada hacia las formulaciones y prácticas educativas como una forma de estudio de una sociedad, enclavada en un micro-espacio. De igual modo, los historiadores

${ }^{9}$ Pretendemos dibujar «un mapa intelectual» de una región, optando romper con la tradición de la circunscripción de los centros de educación nacionales, cambiando de estrategia para acercarnos a la vida social y económica de la misma. Aceptamos este desafío bajo la aplicación de otras perspectivas de análisis históricos, que nos permitan vincular el proceso educativo, con el socio-cultural y de organización institucional. Cfr. Gramsci, A. Los intelectuales y la organización de la cultura, Buenos Aires: Nueva Visión, 1997; Bordieu, P. Cosas dichas, Barcelona: Gedisa, 1993; Duby, G. La Historia continúa, Madrid: Debate, 1993; Bordieu, P. «Los intelectuales y los poderes» y «Las condiciones sociales de la circulación de las ideas», en: Bordieu P. Intelectuales, política y poder. Buenos Aires: Eudeba, 2003. Más específicamente, pero como marco conceptual, Harvey Kaye, en The education of desire, Londres: Routledge, explora la vinculación y diferentes clases de interpretaciones de ideas educativas con su articulación y prácticas, fundamentalmente en el Viejo Mundo. 
— influidos por los planteos teóricos filosóficos de la Nueva Izquierda alemana - direccionaron el estudio del análisis discursivo de los diferentes actores que de una u otra manera intervenían en estas prácticas. Adorno, Horkheimer, Benjamín, Fromm inician un análisis social y favorecen nuevos métodos de formación universitaria Todos ellos tienen incidencia crucial sobre la historia que hace decir a Michel de Certeau la aparición de historiadores confundidos en filósofos y viceversa. No siempre como los expertos o educadores formales, sino como intelectuales.

Para Gramsci las relaciones entre intelectuales y el pueblo-nación deben ser estudiadas teniendo en cuenta la lengua escrita y usada en esta vinculación de diferentes estratos ${ }^{10}$, distinguiendo claramente entre la cultura de emisores de «lengua vulgar» o del pueblo y los doctos o intelectuales, que integran una minoría. Siguiendo su pensamiento, no es un estrato de la población que al llegar al poder crea sus intelectuales sino un organismo seleccionado que asimila individuos particulares en sus cuadros. Los ejemplos típicos son la organización eclesiástica, pero en nuestro caso, es fundamentalmente el militar de la frontera y el inmigrante español e italiano. Es decir, focalizar sobre los mecanismos que permitirían las vinculaciones entre unos y otros.

Nos planteamos el interrogante de ¿cómo analizar una sociedad carente de educadores formales? El marco teórico brindado por Jurgen Habermas nos permite en primer lugar separar a los sujetos que habiendo aprendido determinadas herramientas de conocimiento, como las primarias de leer o escribir, o ambas a la vez, por su competencia obtienen un rango diferencial al ser capaces de generar emisiones simbólicas con una intención comunicativa de entenderlas. Estos significados simbólicos fundan una identidad en una sociedad y les permiten establecer las reglas de la misma.

$\mathrm{Si}$ aceptamos la tesis de Cassirer que «el espacio y el tiempo son la urdimbre en que se halla trabada toda la realidad» podemos sostener que el espacio puede ser considerado como una de las grandes fuerzas que gobiernan las cosas ${ }^{11}$. Siguiendo su línea conceptual, para analizar la cultura de una sociedad, o en este caso de dos centros urbanos, no podemos obviar el efecto de lo espacial, la adaptación esencial del hombre al «espacio, experiencia de las sensaciones que contribuyen a la construcción de un hombre».

\begin{abstract}
Hacia la década del 70 Michel Foucault y Serge Moscovici entre otros, atestiguan un despertar epistemológico que estable la relación entre un lugar - el medio ambiente- y los procedimientos de análisis. Admiten que la historia es parte de la realidad en cuanto "práctica", propuesta desarrollada por Althusser.
\end{abstract}

Concretamente en este estudio desde el punto metodológico nos remite a un desarrollo teórico centrado, por una parte, desde una propuesta que se identifica con la teoría crítica freudo-materialista desarrollada por Theodor Adorno, Herbert Marcuse y Max Horkheimer, que considera al pensamiento dialéctico como una herramienta para un análisis crítico de la sociedad y los fenómenos psicológicos

${ }^{10}$ Gramsci, A. Los intelectuales y la organización de la cultura, 5ta edición, Buenos Aires; Nueva Visión, 1997, págs. 30-31.

${ }^{11}$ Cassirer, E. Antropología filosófica, México: 17a reimpresión, Fondo de Cultura Económica, 1997, pág. 71. 
que actúan en la producción de sus discursos, como en el análisis a través de su producción intelectual, efecto de transformación del poder.

Por otra parte, la fuerza documental y testimonial de vecinos, viajeros y publicaciones periódicas, discursos de gobernadores o autoridades escolares, nos permitirá correlacionar los informes a las autoridades de Buenos Aires y la correspondencia entre estos actores situados en ambas localidades que son nudo de análisis.

A pesar de la complejidad que supone diferenciar la cultura de la estructura social, intentaremos probar los efectos del clima y economías rudimentarias sobre la experiencia emocional colectiva por datos recogidos en especial por los viajeros.

\section{Algunos enfoques historiográficos sobre la educación argentina}

Los primeros estudios históricos de esta temática fueron realizados en las primeras décadas del siglo $\mathrm{XX}$, donde se observó la preeminencia de agentes o funcionarios involucrados en las instituciones de organismos dependientes del ministerio de Educación de la Nación o de la Dirección General de Escuelas de la provincia de Buenos Aires. Este hecho, convirtió a muchos de ellos, en relatos cronológicos con datos estadísticos donde abundan creaciones de establecimientos educativos, planes o leyes, sin toma de posición crítica o analítica sobre los conectores entre educación, cultura y sociedad, en un contexto histórico sobre los cuales estaba diseñada la primera.

No obstante, algunos de estos trabajos de investigación, constituyen verdaderas fuentes históricas en lo que respecta a la invalorable seriedad con que fueron recabados los datos que aportan. Ello permitió que fueran utilizados como herramientas de estudio por los profesores de magisterio, y a su vez, desarrollaran textos para aspirantes a la docencia, en asignaturas como Política Educacional e Historia de la Educación y la Pedagogía de las tradicionales escuelas normales ${ }^{12}$. La lectura de estos textos

${ }^{12}$ Achaval, N. Memoria del estado de la educación común durante el año 1882 en la Provincia de Buenos Aires, Consejo General de Educación, Buenos Aires, 1883; Almandoz, A. R. Bahía Blanca y sus escuelas, Escuela de Artes y Oficios San Vicente de Paul, La Plata, 1928; Bianco, J. La Instrucción Primaria en la Provincia de Buenos Aires, La Plata, 1904; Cárcano, R. 800 analfabetos. Aldeas Escolares, Buenos Aires: Roldán, 1933; Codignola, E. Historia de la Educación y la Pedagogía, Juan Mantovani, Buenos Aires: Ateneo, 1969; De María, M. E. La instrucción primaria en la Argentina (1884-1936), Buenos Aires: El Ateneo, 1936; Díaz, U. La Instrucción primaria bajo el régimen de la Ley 1420, Consejo Nacional de Educación, Buenos Aires, 1940; Manganiello, E. Historia de la educación argentina, Buenos Aires: Librería del Colegio, 1953. Pizzurno, P. La educación en Buenos Aires, Oficina Meteorológica, Buenos Aires, 1910; Portnoy, A. La instrucción primaria desde 1810 hasta la sanción de la ley 1420, Consejo Nacional de Educación, Buenos Aires, 1937; Ramos, J. P. Historia de la Instrucción Primaria desde 1810 hasta la sanción de la Ley 1420, Consejo Nacional de Educación, Buenos Aires, 1937; Salvadores, A. Historia de la Instrucción Pública en Entre Ríos, Museo Histórico de Entre Ríos, Paraná, 1966; Solari, M. H. Política Educacional Argentina, Buenos Aires: El Ateneo, 1967; Zubiaur, J. B. La enseñanza práctica e industrial en la República Argentina; Buenos Aires: Lafanane, 1900. 
propició cierta homogeneidad en el ideario de sus actores, cabe decir, los futuros maestros ante la «historia incorporada» ${ }^{13}$. Por tanto, la historia de la educación argentina y bonaerense, parecía ser el producto del voluntarismo de un grupo de intelectuales instalados en Buenos Aires, en pos de un estado moderno, con acciones iniciadas en la década del veinte del siglo XIX, y que se construyen definitivamente en el ochenta. Esta centralización del quehacer educativo y en algunas localidades de la provincia al norte del Salado, generó en el inconsciente colectivo la inexistencia de modelos culturales propios de comunidades con determinado aislacionismo geográfico.

A partir de los últimos treinta años, se produce una renovación en la historiografía educativa, al existir un replanteamiento del objeto de estudio, con aportes provenientes de la sociología y la filosofía antropológica, separados de una historia a la manera de la Nueva Escuela pretendida por los iniciadores. Se comienza a perfilar una renovación en el campo histórico en sus debates y abordajes, con notoria influencia de la École Prátique Hautes Etudes, conocida como de los Annales (1947), que plantean nuevos matices tanto en la historia social, económica y cultural. Adriana Puiggrós ${ }^{14}$, Gregorio Weinberg, Carlos Newland, Fernando Barba, Pablo Pineau, Silvina Gvirtz, entre otros, constituyen una nueva generación de investigadores que a partir de la década del ochenta, atestiguan un nuevo despertar epistemológico de la historia de la educación. Nuevas publicaciones han generado espacios de intercambio y difusión en este campo, tanto de nuestro país como otras naciones latinoamericanas ${ }^{15}$. Su contribución enriqueció el espectro temático, abriendo un interesante abanico en el análisis donde la educación no adquiere un carácter solo descriptivo y explicativo sino se convierte en un fenómeno antropológico y sociológico que explica la acción o predominio de intelectuales que le dan identidad a un determinado cuerpo urbano ${ }^{16}$.

${ }^{13}$ Alliaud, A. Los maestros y su historia: los orígenes del magisterio argentino/1, Biblioteca Política Argentina, CEAL, 1993, págs. 31.

${ }^{14}$ Puiggrós, A. Historia de la educación en la Argentina. Sujetos, disciplina y currículum en los orígenes del sistema educativo argentino (1885-1916), 3ra. edición, T. I, Buenos Aires: Galerna, 1996. Galerna Editorial. Este libro, tal como lo manifiesta la autora, es producto del programa «Alternativas pedagógicas y prospectiva educativa de América Latina» (APPEAL), que desarrolla en la Universidad Autónoma de México desde 1980, y del Consejo Nacional de Investigaciones Científicas y Tecnológicas, y las investigaciones siguientes, definen modelos educativos dominantes de América latina, desde 1880 a 1980. El encuadre metodológico indica una marcada renovación de análisis en la teoría crítico freudo-materialista de Adorno, Althusser y Laclau.

${ }^{15}$ Estos trabajos fundamentalmente, han sido desarrollados en las publicaciones de las facultades de Filosofía y Letras de la Universidad Nacional de Buenos Aires y por la de Ciencias de la Educación de la Universidad Nacional de La Plata, sumado al Anuario de Historia de la Educación de la Sociedad Argentina de Historia de la Educación.

${ }^{16}$ Teniendo en cuenta que el concepto «intelectual» es impreciso y multívoco, tomamos como marco teórico las definiciones forjadas por Antonio Gramsci en primer lugar, Carlos Altamirano, Louis Bodin, Pierre Bordieu, Goody Jack, Gouldner Alvin, Heyck Thomas, Jackes Le Goff, Roger Chartier y Max Weber, entre otros. 


\section{Estado general de la cuestión}

Tal como lo afirmamos anteriormente, el desarrollo histórico educativo del período que se pretende analizar, ha sido abordado, en su generalidad por pocos historiadores. Esto se ha debido particularmente, por un preconcepto que ha considerado que las prácticas educativas y su evolución histórica, son fundamentalmente materia de análisis para los especialistas en Ciencias de la Educación.

No obstante, como dijimos, se han realizado estudios históricos fundamentalmente de la ciudad de Buenos Aires o de localidades cercanas que hoy integran el gran Buenos Aires, son importantes fuentes documentales, cuyas ediciones datan de las primeras décadas del siglo XX. Para ello, bien podemos nombrar los estudios tradicionales de Juan P. Ramos, Antonio Portnoy, José Campobassi, Urbano Díaz, Hernán Gómez, Juan Mantovani, Juan María Gutiérrez, Evaristo Iglesias, Víctor Mercante, Antonino Salvadores y Gregorio Uriarte.

Evaristo Iglesias con su obra La escuela pública bonaerense hasta la caída de Rosas, editada en 1946, fue uno de los que se introduce en la problemática de las escuelas de campaña, pero sin llegar a profundizarlo en lo referente al espacio geográfico que nos ocupa. Este, puede representar un eje espacial cuya construcción fuera altamente significativa y diferente por su aislacionismo, con el resto del territorio bonaerense, tomando como parámetros varias décadas en las que la comunicación con Buenos Aires y otros centros urbanos cercanos era exclusivamente vía marítima.

Han iniciado una Nueva Historia de la Educación apelando a mayor cantidad de referentes de relación, sin alejarse del marco historiográfico: Juan Carlos Tedesco, Gregorio Weinberg, Carlos Newland, Daniel Suárez, Ethel Manganiello y su método generacional, Adriana Puiggrós y un grupo importantísimo de colaboradores, Esteban Fontana, Isabel M. Blas, S. Carli y Elena Rebok, constituyen una nueva generación de investigadores. Adriana Puiggrós, si bien lo manifestado anteriormente en cuanto a la renovación metodológica, reconstruye históricamente la educación de las provincias, utilizando idéntico marco cronológico ${ }^{17}$.

Fernando Barba anticipa, en su investigación sobre la legislación de la educación de la provincia de Buenos Aires, las transformaciones operadas en el sistema educativo y en la administración escolar, después de Caseros. Con posterioridad, nos introduce en el conocimiento de la legislación educativa en la etapa posterior a la independencia ${ }^{18}$ Carlos Newland estudia con profundidad la educación elemental

${ }^{17}$ Puiggrós A. La educación en las Provincias y territorios nacionales, Historia de la Educación en la Argentina. 3a. edición, Buenos Aires: Galerna, 1996. Jorge Myers considera que muchos de estos historiadores, a partir de 1953 con la aparición de Imago mundi, generan una ruptura del hasta entonces triunfal proyecto de historia cultural de José Luis Romero, introduciendo nuevos matices. Myers, J. «Pasados en pugna: La difícil renovación del campo histórico argentino entre 1930 y 1955», en: Neiburg, F. y Plotkin, M. (comps.) Intelectuales y expertos. La constitución del conocimiento social en la Argentina, Buenos Aires: Paidós, 2004.

${ }^{18}$ Barba, F. «La Ley de Educación Común de Buenos Aires de 1875», Trabajos y Comunicaciones, Universidad Nacional de la Plata, Facultad de Humanidades y Ciencias de la Educación, 1968, págs. 53-65; Barba, F. «En torno a los Reglamentos de Educación Primaria de Buenos Aires. 1816-1818», Cuarto Congreso de Historia de 
en Buenos Aires, en la etapa rivadaviana y rosista, reconstruyendo las transformaciones críticas de los autores clásicos y las doctrinas ideológicas vigentes en ese dominio ${ }^{19}$.

Pilar Gonzalez Aispuru junto a Dorothy Tanck de Estrada ha planteado interesantes trabajos que incursionan en los valores educativos de sociedades regionales como nuevos parámetros de estudios de las familias latinoamericanas 20

Los estudios de género han aportado por el carácter de la mujer como uno de los agentes educadores más prácticos ${ }^{21}$. Estas autoras han direccionado e influido en diferentes aspectos en estudios locales como los de Graciela Morgade, Mabel Belluci, Dora Barrancos, Inés Dussel y Silvia Gvirtz, entre otras. Existe, en ellas, una mirada hacia formulaciones de prácticas educativas femeninas, con nuevos aportes teórico-metodológicos de la Escuela de los Annales y sus continuadoras europeas y otras.

No obstante, no se ha avanzado en estudios de carácter regional, específicamente de la región del sudoeste bonaerense.

Alberto Reyna Almandos en 1928 como contador de la Dirección General de Escuelas de la provincia de Buenos Aires, presenta uno de los estudios más completos sobre la educación en Bahía Blanca. Si bien encuadrado en la escuela de la historia educacional, su libro contiene un aporte tanto documental como estadístico recabado en los acervos documentales oficiales y archivos provinciales ${ }^{22}$. Ricardo Levene, en 1939, realiza igualmente un completo estudio sobre la fundación de las Escuelas Públicas en la provincia durante la gestión de Sarmiento ${ }^{23}$. Dentro del mismo carácter de publicaciones dirigidas por el mismo autor se encuentra Historia de la Provincia de Buenos Aires, donde se resumen brevemente bajo el título «aspecto religioso y cultural» la evolución educacional de Bahía Blanca y Carmen de Patagones ${ }^{24}$. En 1978, en adhesión al sesquicentenario de Bahía Blanca, publico junto a María Angélica García un estudio de la educación argentina, focalizada exclusivamente en el contexto

Los Pueblos de la Provincia de Buenos Aires, Archivo Histórico de la provincia de Buenos Aires, Mar del Plata: Theoría, 1997, págs. 49-55.

${ }^{19}$ Newland, C. Buenos Aires no es pampa. La educación elemental porteña (1820-1860), Buenos Aires: Grupo Editor Latinoamericano, 1982.

${ }^{20}$ Ambas investigadoras coordinaron y presentaron interesantes trabajos de investigación sobre esta temática en el $49^{\circ}$ Congreso Internacional de Americanistas, realizado entre el 7 al 11 de julio de 1997.

${ }^{21}$ Las norteamericanas Donna Guy y Sarah Roberth y las argentinas Graciela Morgade y Cecilia Román llegan a plantear desde las problemáticas de la Sociedad de Beneficencia hasta la relación entre género y educación. Muchos de estos trabajos fueron presentados en las VI Jornadas de Historia de las Mujeres y I Congreso Iberoamericano de Estudios de las Mujeres y de Género, realizado en la Facultad de Filosofía y Letras de Buenos Aires, en agosto del año 2000.

${ }^{22}$ Reyna Almandos Bahía Blanca y sus Escuelas. Reseña Histórica, La Plata: Escuelas de Artes y Oficios, 1928.

${ }^{23}$ Levene, R. Fundación de las escuelas públicas en la Provincia de Buenos Aires durante el gobierno escolar de Sarmiento. 1856-1861m 1875-1881, Archivo Histórico de la Provincia de Buenos Aires. La Plata: Taller de impresiones oficiales, 1939.

${ }^{24}$ de Lázaro, J. F. «Bahía Blanca» y «Patagones», en: Levene, R. Historia de la Provincia de Buenos Aires y formación de sus pueblos, Vol. II, La Plata: Taller impresiones oficiales, 1941. 
bahiense, abarcando la etapa de 1880-1930. Difícil realizar un juicio de valor a los desaciertos propios de la visión actual hacia una primera publicación, no obstante, considero pretendimos abrir un espacio de estudio en el área.

Edith Carmen De Benedetti y Emma Nozzi, historiaron la evolución de las escuelas públicas específicamente en Carmen de Patagones, con los parámetros metodológicos de las antiguas historias de la educación: relatos detenidos en los primeros educadores y construcciones escolares. No obstante la primera realiza un aporte documental preciso que marca una perspectiva muy amplia y rigurosa.

Consideramos que no obstante el valor documental, fundamentalmente estos autores, no alcanzan las expectativas que nos proponemos, al plantearnos una combinación de un espacio social definido y de prácticas educativo-culturales concretas. Instalamos a la educación como objeto desde el cual miramos un centro urbano, su desarrollo, el establecimiento de categorías socio-culturales, antecedentes, pioneros o fundadores. Estos «nuevos problemas» ponen en tela de juicio las historias regionales tradicionales, buscando enriquecerlas, proponiendo «nuevos temas». 
Primera parte

Rupturas y continuidades culturales y educativas en el sudoeste bonaerense: del fin del Régimen a la consolidación del modelo rivadaviano 


\section{Capítulo 1}

\section{Representaciones culturales y educativas. Diversidades entre Patagones y la Fortaleza Protectora Argentina}

\section{Parámetros históricos fundacionales y dimensiones culturales de la ciudad del Carmen y de la}

Fortaleza Protectora Argentina (1779-1828)

En virtud a los interrogantes planteados en los objetivos de esta tesis, corresponde dar respuesta a razones vinculantes que intervinieron en la construcción de una sociedad cuyo elemento distintivo fue el aislamiento y la incomunicación con las autoridades del poder central.

Zorroaquín Becú, advierte desde el inicio de su obra, El federalismo argentino, que «la ubicación de las ciudades en el territorio argentino no quedó librada al azar de las circunstancias, ni fue obra del capricho español» ${ }^{1}$. El desconocimiento geográfico de los conquistadores españoles, no fue para este autor, impedimento para establecer lo que llama «puestos» urbanos que consolidaran las comunicaciones. Las ciudades, que crecieron sobre el litoral atlántico, estuvieron favorecidas por una mejor relación económica y vínculos socio-culturales con países europeos. Mientras que las del interior, comenzaron a atomizarse en razón de la falta de contacto entre ciudades entre sí. Pero, tanto en unas como otras, la distancia y el constante peligro de ataques indígenas, fueron factores comunes que afectaron su crecimiento y sociabilidad mutua. Además favorecieron — para este autor - la conformación de núcleos urbanos autónomos, ya sea como ciudad-fortaleza o como ciudad-cuartel. La alta valoración que le confiere Zorroaquín a cuestiones geográficas, como las dificultades de comunicación entre las ciudades entre sí, se sumaron a los obstáculos políticos de la Corona, para mantener la cohesión suficiente de tan vasto territorio. Otro factor a considerar fue la supresión de las Intendencias

${ }^{1}$ Zorroaquín Becú, R. El Federalismo Argentino. Buenos Aires: Torre de Babel-Perrot, 1958, pág. 19. 
como consecuencia de cierto espíritu localista nacido del aislamiento de las ciudades. Si bien este localismo no fue el germen del federalismo, condicionó a los legítimos anhelos regionales, llegando a propiciar una tendencia separatista, como los de Paraguay, Bolivia o Uruguay. Pero retomando el centro de nuestro interés, el territorio bonaerense, podemos afirmar que la prevalencia del puerto de Buenos Aires desde el punto de vista político y económico a partir de 1776 y su elevación al rango de capital del Virreinato, favoreció la aparición de una élite porteña que logra alcanzar prestigio y respetabilidad. Estos últimos ligados no solo a su poder económico sino a nuevas prácticas educativas que los ponen en contacto con las últimas vertientes ideológicas de Europa. Zorroaquín Becú destaca cómo, a partir de este momento, se produce un cambio en el eje cultural virreinal: la educación escolástica de las ciudades del centro y noroeste del virreinato, fue modificada por la renovación educativa e ideológica nacida de los cambios revolucionarios europeos y americanos, nutridos por el pensamiento liberal de Carlos III y que trasciende a los principios de los hombres de Mayo.

Chiaramonte, retoma estos conceptos, y al igual que Zorroaquín, indica que la disolución del estado español en las Indias pudo originarse en el papel clave que tuvieron el aislamiento y las distancias que dificultaban el nivel de comunicación de determinados núcleos urbanos. La creciente debilidad de los vínculos administrativos del estado español, sumada a la inexistencia una clase dirigente de amplitud nacional y a la maduración de un espíritu de rechazo por parte de esta burguesía, hacia el período colonial tardío, fueron factores que coadyuvaron a la inexistencia de una nación en la primera mitad del siglo XIX ${ }^{2}$. El derrumbe de los imperios ibéricos no estuvo ajena para este autor por la presión ejercida de una nueva potencia en la arena mundial, Inglaterra, y de los factores de resentimiento y disconformidad existentes en todas las capas sociales americanas hacia el dominio colonial ${ }^{3}$. Chiaramonte apunta que para estudiar la cuestión regional en la Argentina como cuestión nacional, centro del problema, el análisis debe focalizarse en la estructura social, en razón de la movilidad que ésta misma conlleva. Pero, por otra parte, para constituir una nación fue necesario tomar a la cuestión regional como base de estudio, para llegar a lo nacional. Tras ofrecer un panorama de la conformación regional, nos detuvimos en el punto principal de nuestro interés: el territorio bonaerense: la provincia, es para este autor, una dimensión sólida, de lo que se puede llamar región. Carmen de Patagones quedaría enmarcada, siguiendo este pensamiento, como un núcleo urbano surgido durante el proceso de ocupación del litoral atlántico, afectada por el aislamiento dentro del nivel comunicacional del período español, cuestión que habría favorecido la cohesión social de sus habitantes, un marcado concepto localista, ante la inexistencia de auxilios exteriores, una alta valoración individual que provocaban su propia suficiencia ante un medio hostil, el hábito a la soledad y a la pobreza que paradójicamente se enfrentaba a

${ }^{2}$ Chiaramonte, J. C. «La cuestión regional en el proceso de gestación del Estado Nacional argentino. Algunos problemas de interpretación», en: Ansaldi, W. y Moreno, J. L. Estado y sociedad en el pensamiento nacional. Buenos Aires: Cantaro, 1989, pág.164.

${ }^{3}$ Chiaramonte, J. C. «La cuestión regional en el proceso de gestación del Estado Nacional argentino», en: Palacio M. La unidad nacional en América Latina. Del regionalismo a la nacionalidad, México: El Colegio, 1983, págs. 53. 
la necesidad por mantener su ascendencia hidalga ${ }^{4}$. Este localismo en el territorio bonaerense, no logró, a nuestro entender, consolidar, en las puertas del Río Negro, una región en razón de la escasa importancia económico-social para los centros de poder y la escasez de medios para constituirse en un centro cultural, al primar la consideración como fortaleza de aislamiento por encima de sus peculiaridades como ciudad.

Fernando Barba, por su parte, consideró que el interés demostrado por «las autoridades españolas durante el último cuarto del siglo XVIII, en establecerse y poblar puntos estratégicos en la Patagonia», se debió a la necesidad de evitar una posible ocupación de la misma por parte de ingleses, franceses, holandeses e incluso estadounidenses ${ }^{5}$. La obra de Tomás Falkner y el aumento de la presencia de naves extranjeras aceleran el interés de España por ocupar esta región, que fue paralelo al de la poblamiento del norte del territorio bonaerense llevado a cabo por el virrey Vértiz. Barba pone el acento en la Real Orden de 1778, que mandaba al intendente de Galicia colectar en aquel reino doscientas familias españolas, a quienes se les ofrecería vivienda, tierra en propiedad, animales y herramientas. Según las fuentes documentales ofrecidas por el autor, las condiciones de vida de estos pobladores, habían variado sustancialmente en 1786, detallando las penurias de quienes habían poblado las márgenes del río Negro. Este autor, en este trabajo, ha identificado empíricamente en el análisis de las representaciones sociales de la cultura maragata, un conjunto de conocimientos denotativos (actitudes, normas y valores) y pragmáticos (roles), compartidos por un grupo de campesinos españoles, criollos, esclavos y presidiarios. En lo que respecta a los primeros, destaca la capacidad para enfrentar la falta de seguridad y a su vez el terror ante un posible ataque para sembrar en zonas más alejadas de las orillas del río. La casi permanente exposición de sus vidas para las tareas cotidianas «alejándose aún un corto trecho de la población» ${ }^{6}$. En referencia a los conocimientos pragmáticos, el incumplimiento en el reparto de la carne y de alimentos con lo convenido con la Corona, destinado «a enfermos y ministros empleados» aparece como un indicador de conductas que aceptaban que el poder estuviera desigualmente distribuido, respetando la diferencia ante personas con alto status aunque por otra parte, se muestran permeables a la cooperación y cuidado de los débiles (mujeres, niños, enfermos) ${ }^{7}$.

${ }^{4}$ Chiaramonte, J. C. Op. cit, pág. 57: El escribano Francisco Pita, en su obra Remembranzas. Contribución a la Historia de Mercedes y Carmen de Patagones. (s/e). en sus páginas iniciales transcribe un artículo del periódico Nueva Era, fechado el 25 de julio de 1925, según el cual «a los fundadores de Patagones, sus hijos y descendientes legítimos, les correspondieron los título de Hidalgos y Caballeros», privilegio que Carlos III otorgo a los pobladores que allí se asentaran. Esta obra fue consultada en su totalidad en el A.H. de Carmen de Patagones.

${ }^{5}$ Barba, F. «Algunos aspectos relativos al poblamiento de Carmen de Patagones», Trabajos y Comunicaciones, n. ${ }^{\circ}$ 24, $2^{\circ}$ época, Facultad de Humanidades y Ciencias de la Educación, U.N.L.P, La Plata, 1996, págs. 133-145.

${ }^{6}$ Barba, F. Op. cit., pág. 135.

${ }^{7}$ Barba, F. Op. cit., pág. 136. 
Pero, en cuanto a la producción y difusión de conocimientos, Fernando Barba no duda en afirmar que «no fue la educación una de las preocupaciones de la Corona en sus colonias americanas» ${ }^{8}$. Para el autor fueron los cabildos y conventos los agentes educadores que favoreció con competencias intelectuales a un sector minúsculo de la población. Evidencia clara de una hegemonía ideológica que establece una dominación de clases, que tendrá su clara ruptura con la incursión de Mariano Moreno en 1810, ya sea desde el prólogo del Contrato Social de Rousseau como posteriormente lo difundirá fray Francisco de Castañeda desde su periódico Los Amigos de la Patria y la Juventud.

Hernán A. Silva, pone el acento en los objetivos económicos y estratégicos que condujeron a la Corona Española a partir de la Real Orden del 7 de marzo de 1778 para ocupar los territorios australes. Paradójicamente, existía, según este autor, una «posición negativa, con respecto a la utilidad de los establecimientos sureños, aún antes de su formal instalación»? ${ }^{9}$.

Cabe ahondar sobre dos planteos que den validez a estos presupuestos. Una sociedad cuyo elemento distintivo es el aislamiento y la incomunicación ¿construye un concepto diferencial en sus prácticas cotidianas? Esta autonomía ¿favorece comportamientos políticos, morales, religiosos o institucionales que le dan una especificidad en sus prácticas sociales? Y por último, esa sociedad legitima al fundamentalmente en su posición de comunicador?

Resulta por tanto necesario la identificación de los parámetros histórico-fundacionales, que se han tomado como caso en dos centros urbanos nacidos uno como «fuerte» ${ }^{10}$ y el otro como «fortaleza» ${ }^{11}$. El fuerte de la ciudad del Carmen buscó, como la palabra indica signos de «resistencia, robustez y reguardo como espacio de defensa». La Fortaleza Protectora Argentina, del bajo latín fortalitia, es «la virtud que consiste en vencer el temor» ${ }^{12}$. Etimológicamente ambas palabras nos pueden conducir a una reflexión que en la traza de quienes decidieron su fundación, constituyeron la exclusiva significatividad de sus destinos. Si para Jurgen Habermas «los ciudadanos son personas que han desarrollado sus identidades personales en el contexto de ciertas tradiciones, en entornos culturales específicos y que necesitan tales contextos para mantener sus identidades» ${ }^{13}$, puede tener validez reconocer las causales por las cuales estos dos centros urbanos fueron fundados. El acceso a una tradición en comunidades aisladas es patrimonio de quien tiene la capacidad de describirla, comprenderla y justificarla en forma argumentativa.

Hofstede ${ }^{14}$ ha postulado la existencia de dimensiones que diferencian a las culturas: nos adscribimos a la distancia del poder y el control y regulación de las emociones de un individuo frente a la incertidumbre.

${ }^{8}$ Barba, F. «En torno a los reglamentos de educación primaria de Buenos Aires. 1816-1818», Cuarto Congreso de Historia de los Pueblos de la Provincia de Buenos Aires. A.H.P.B.A, «Ricardo Levene», Tomo I, Mar del Plata: Theoría, 1993, págs. 49-55.

${ }^{9}$ Silva, H. A. La economía pesquera en el Virreinato del Río de la Plata, CONICET, 1980, págs. 61-62.

${ }^{10}$ Del latín fortis, forte.

${ }^{11}$ Del latín arxs, arcis, castellum (castillo).

${ }^{12}$ Adjetivo que proviene del latin fortis.

${ }^{13}$ Habermas, J. La ética del discurso y la cuestión de la verdad, Buenos Aires: Paidós, 2006, pág. 54.

${ }^{14}$ Hofstede, G. Culture `s consequences, California: Thounsands Ocks, 2001. 
Como primer punto, identificamos determinados indicadores que fueron traducidos por quienes participaron en la empresa de fundación de la ciudad del Carmen. Coordenadas efectivas que significan reconocer en el discurso de los fundadores, viajeros, o testigos de la iniciativa, ideas, nociones o categorizaciones, que nos demuestran conceptos existentes y mecanismos ideológicos, de una instrucción o educación determinada. Necesaria articulación entre quien los educó, cómo fue esta acción y que modificaciones educativas pudo producir en su entorno.

La lectura de estos testimonios, no sólo transmiten una enumeración cronológica de los hechos, sino que nos remite a sus emociones y a la descripción de significados muchas veces ocultos. En ellos aflora la realidad de quien realiza el acto interpretativo: como protagonista y crítico. Quienes fueron capaces de la producción de un texto y a su vez hacedores de una empresa colonizadora, mantienen una condición que los diferencia de los otros protagonistas. Pudieron escribir, informar a las autoridades, requerir por sus necesidades, es decir, fueron competentes de la producción de saberes en una sociedad. En la concepción de Neiburg y Plotkin, son, por un lado, productores de conocimiento de acuerdo a las lógicas del momento histórico que viven y a un contexto histórico específico. La validación de los saberes de estos hombres de fines del siglo XVIII, no respondía - en la mayoría de los casos - «a intelectuales que reclaman como fundamento de legitimidad para sus intervenciones una forma de pensamiento crítico e independiente de los poderes...», sino a los «expertos» de este período histórico, cuyos conocimientos son técnicos o especialistas que actúan en nombre de la técnica y la ciencia ${ }^{15}$.

Si seguimos este pensamiento, podemos inferir que la producción de saberes en una sociedad — desde el plano profesional o doméstico - genera en principio cierta jerarquización por el conocimiento de una estrategia. En una sociedad de aislamiento, la estrategia de comunicación verbal o escrita, o la transferencia del conocimiento científico o práctico, da mayor legitimidad a algunos individuos que otros y generaría a su vez nuevos actores sociales con estrategias cognitivas y/o productivas, en los diferentes oficios.

\section{Carmen de Patagones. La palabra de los fundadores y primeros colonizadores}

La validez de los escritos de José Juan Biedma, Manuel Álvarez ${ }^{16}$, Antonio de Viedma ${ }^{17}$, Francisco de Viedma y Ambrosio $\mathrm{Cramer}^{18}$ son incuestionables en cuanto a su valor documental. En ellos no escapa

15 Neiburg, F. y Plotkin, M. «Intelectuales y expertos. Hacia una sociología histórica de la producción del conocimiento sobre la sociedad en la Argentina», en: Neiburg F. y Plotkin M. Intelectuales y expertos (comp.), Buenos Aires: Paidós, 2004, pág. 15.

${ }^{16}$ Prefacio de la edición de Biedma, J. J. Crónica histórica del Río Negro de Patagones (1774-1834), Buenos Aires: Juan Cramer Editor, 1905.

17 Viedma, A. «Diario de una viaje a la costa patagónica para reconocer los puntos en donde establecer poblaciones», en: De Ángelis, P. Colección de Obras y Documentos relativos a la Historia Antigua y Moderna de las Provincias del Río de la Plata, 2a edición, Tomo IV, Buenos Aires: [s/e], 1910. 
ni la subjetividad del paradigma kantiano aún en el giro lingüístico o en sus intuiciones ni la objetividad en el análisis del contexto histórico que representa. Actúan no sólo como cronistas históricos sino como intérpretes de la cultura de una época con la singularidad en la distinción de simbolismos individuales o colectivos.

La Crónica histórica del Río Negro escrita por José Juan Biedma de 1905 en memoria de su hermano Alberto M. Biedma ${ }^{19}$, fue una culminación acabada de los Apuntes que edita en $1887^{20}$. Esta edición contiene una memoria descriptiva de Patagones escrita por el vecino Manuel Álvarez en marzo de 1852, dirigida a Valentín Alsina.

Abundan enunciados sobre vivencias y representaciones de los sujetos partícipes. Emociones que nos permite construir un sistema de relaciones y socialización que distinguió a una población.

Como instrumentos de conocimiento y de comunicación, establecimos certidumbres que surgen sobre observaciones concretas de los primeros pobladores y de quienes tenían la posibilidad de mantener correspondencia escrita entre Buenos Aires y los puertos de frontera. Ello nos ha permitido establecer algunas relaciones,

a) El núcleo de valores: La voz de los primeros pobladores son constancias expresas del protagonismo que adquieren en una fase histórica que caracterizó al mundo hispánico de «las grandes revoluciones». El descrédito de las autoridades en los estratos sociales bajos, trascienden no solo a lo político, institucional sino también a lo religioso. En este contexto, intervienen los cambios políticos que se expanden a todos los órdenes de la vida cotidiana, entre ellos a la construcción de un nuevo hombre. Como sostiene Mónica Quijada, la potesta populi es la preposición que permite explicar los cambios que con celeridad se dan en el mundo hispánico y que contribuye a modificar un nuevo imaginario en base al potencial que adquieren a partir de estos momentos hombres ajenos a la Iglesia: son los nuevos lectores y quienes tienen estudios universitarios ${ }^{21}$. En esta etapa, el iluminismo, en el sentido más amplio del pensamiento, los libera del pensamiento mágico y del miedo a quienes les ordenan. La superioridad del hombre reside en el saber, y en él se encuentran tesoros que los reyes no pueden comprar $^{22}$. Este hombre de fin de siglo XVIII, adquiere mayor seguridad en sí mismo, desplegando ante sus autoridades peticiones por sus derechos. Estas nuevas ideas, tienen el impacto lógico sobre las mentalidades y comportamientos, que en el caso específico de quienes irían a poblar Patagones, favorece al atrevimiento de la queja

${ }^{18}$ Cramer, A. «Reconocimiento del Fuerte del Carmen del Río Negro, de los puntos adyacentes de la Costa Patagónica», en: De Ángelis, P. Op. cit.

${ }^{19}$ Biedma, J. J. Crónica Histórica del Río Negro de Patagones (1774-1834), Buenos Aires: Juan Canter Editor, 1905. Escrito en homenaje a su amor al pueblo de Patagones, tal como lo declara en el prefacio. Se ha consultado además la edición de 1903 que se encuentra en el AGN.

${ }^{20}$ Biedma J. J. Apuntes históricos del Río Negro seguidos de una brevísima reseña de sus más importantes pueblos, Viedma: [s/e], 1887.

${ }^{21}$ Quijada, M. «La potestas populi: una revisión del pensamiento político hispánico y la modernidad», en: Bragoni, B. y Mata, S. E. (comps.) Entre la colonia y la República, Buenos Aires: Prometeo, 2008, pág. 32.

${ }^{22}$ Horkheimer, M. y Adorno, T. W. Dialéctica del iluminismo, Buenos Aires: Sudamericana, 1994, pág. 16. 
por el sufrimiento a que los ha sometido la Corona española y sus autoridades virreinales, en un espacio de escasa comunicación exclusivamente marítima. En determinados momentos, la incomunicación fue absoluta y provocaba el padecimiento de «todo género de privaciones». Transmitir la sensación de engaño que sufrieron las familias colonizadoras al creer lo que se les había prometido, siendo tratados peor que presidiarios, sufriendo un penoso destierro ${ }^{23}$. Como variables dependientes, empleamos los documentos que testimonian emociones de los primeros colonos, traducidas en las palabras de Biedma: el abandono de «la patria, la familia, posición distinguida, fortuna, para afrontar sufrimiento y penurias físicas y morales ${ }^{24}$. La incertidumbre tendía a generar en estos habitantes altos niveles de ansiedad por una parte, y por otra, el refuerzo de una mayor sociabilidad ante la distancia del poder central.

b) Equilibrio relativo en la relación de fuerza con los naturales: Francisco de Viedma se distinguió por la actitud inicial de amigabilidad de su tripulación para con el indígena como una forma de justificar la comunicación con ellos puede cobrar validez por el significado en el contexto en que lo realiza. Cabría en estas palabras - con la ruptura temporal necesaria- la concepción de nación de Benedict Anderson, en cuanto a comunidad política «imaginada». Dado que sus miembros no se conocen entre sí, pero, tienen lazos en común. Y como también «limitada», en cuanto a la finitud de sus fronteras. Existe por tanto en Viedma una idea o imagen que le permite identificar las líneas que ligan a una comunidad diferente, de intereses compartidos, de un pasado colectivo y de una lengua desconocida para los españoles. Por lo tanto, interpreta que esta nación patagónica, originaria, es algo dinámico y será de construcción diaria, debiendo proceder a la ruptura de la principal limitación o «frontera»: conocer su idioma. Hay por parte de quienes realizan los reconocimientos del Río Negro la decisión de interpretación que busca abordar el carácter de nación a partir de los rasgos de su corteza territorial de esta población, a la que reconoce su autonomía y distinción ${ }^{25}$. «Hasta el 25 continuaron las visitas de los indios: ese día condujeron a bordo una pampa que hablaba regularmente el español. Ella les comunicó las primeras noticias relativas a los naturales de esas comarca» ${ }^{26}$, práctica primaria que facilitará la ruptura del aislamiento lingüístico de los colonizadores con las culturas aborígenes.

c) En esta primera etapa fundacional ¿es posible identificar en esta sociedad como plantea Angenot ${ }^{27}$, que existieron hombres con marcada dominación discursiva, que daban significado o autoridad sobre lo conocido y las formas de conocer? ¿Esta dominación discursiva se traducía en

${ }^{23}$ Las «relaciones» de un sargento Michan son testimoniales de esta situación al decir que se encuentra en «el más miserable estado que un presidiario», en: Biedma, 1905, pág. 110.

${ }^{24}$ Biedma (1905), pág. 106.

${ }^{25}$ Gorelik, A. Miradas sobre Buenos Aires. Historia cultural y crítica urbana, [s/1]: Siglo XXI, 2004, pág. 22. Este autor, utiliza el término fisiognomía, en el sentido de Alexander Cosenz, quien a fines del siglo XVIII, establecía un tabla de comparaciones entre rasgos humanos y paisajes.

${ }^{26}$ Biedma, Op.cit., pág. 52.

${ }^{27}$ Angenot, M. El discurso social. Los límites históricos de lo pensable y lo decible. Trad. Hilda García, Buenos Aires: Siglo XXI, 2010, pág. 28. 
una forma de estratificación social? En la sociedad de la Ciudad del Carmen podemos distinguir en esta primera etapa de aislamiento, la existencia de un grupo de intelectuales españoles, que sin pertenecer a una élite económica, mantenían la reputación o prestigio que le otorgaban sus estudios o diplomas universitarios. En respuesta a lo puntualizado previamente por el Doctor Fernando E. Barba, este sector constituía un pequeño grupo dentro de la nómina de pobladores que acompañaba las empresas y poblaron el establecimiento, como inmigrantes o empleados de la Corona.

\section{La estadística como criterio de análisis metodológico}

Con respecto al último punto, que a su vez es contenedor de los otros dos, hemos recurrido metodológicamente a establecer una relación con los datos que aportan las fuentes sobre los primeros habitantes de la Ciudad del Carmen, en lo que respecta a su profesión u oficio, y si el documento lo permite, nivel educativo, formación profesional e ingresos. Este análisis estadístico contribuiría a hacer a tener una mirada sobre la sociedad y la construcción de estratos en relación al conocimiento como facilitador de poder económico y político al igual que de estrategias de comunicación. Buscamos construir un sistema de relaciones que englobara además regularidades mensurables en el lenguaje.

En La Relación de los primeros pobladores que acompaña en la Crónica de Biedma, existe una categorización de los mismos llamados «Fundadores civilizadores» ${ }^{28}$. Brevemente, realizamos una digresión y nos detenemos en el término «civilizar». Enunciador legítimo que responde a lo perceptible en una coyuntura o contexto histórico determinado a la fecha de la primera edición de esta obra: 1905. «Civilizar», significado y a su vez significante, impuesto por Sarmiento a partir de 1849, es la expresión legítima de quien se arroga el derecho de hablar sobre «alteridades», lo culto, lo urbanizado, lo socializado: «La palabra civilización viene visiblemente de ciudad, civitas. Ciudad es sociedad. Civilizar a los hombres es hacerlos propios para la ciudad, la sociedad ${ }^{29}$, discurso que se legitima a través del derecho de fiscalización sobre los que no tienen derecho a la palabra: los «bárbaros», los salvajes, los analfabetos, los niños.

En esta Crónica de Biedma, adjunta además, una relación o matrícula de los pobladores, que corresponde a su ingreso a partir de octubre de 1779 y hasta diciembre de 1783. Si hacemos uso de esta matrícula podemos separar a aquellos que — por inferencia y por su función - y en relación a lo que Gramsci llama, «cuestión de la lengua» ${ }^{30}$, formaban una minoría que hacían uso corriente del latín

${ }^{28}$ Barba, F. E. «Pobladores y Empleados de Carmen de Patagones 1779-1810», en: Separata del Sexto Congreso Nacional y regional de Historia Argentina, Academia Nacional de la Historia, Buenos Aires, 1997, pág. 149. El autor valida con documentos originales del AHPBA «Ricardo Levene» la nómina publicada por Biedma.

${ }^{29}$ Sarmiento, D. F. Educación Común en el Estado de Buenos Aires, 2a edición, Buenos Aires: El Censor. Página X. (Plan Combinado de Educación común aplicable al Estado de Buenos Aires).

${ }^{30}$ Gramsci, A. Los intelectuales y la organización de la cultura, 5a edición, Buenos Aires: Nueva Visión, 1997, pág. 29. 
literario y del vulgar, o de las nuevas lenguas modernas como el español, italiano o inglés. Aspecto vedado a la población del acceso al libro, a la comunicación y por ende, a la ciencia. En esta categorización, estarían a nuestro entender, los cirujanos, los sangradores, escribientes, capellanes, o lenguaraces.

La inclusión de los lenguaraces, la tomamos como actores capaces de facilitar la ruptura de una comprensión etnocéntrica del mundo por parte de los europeos y facilitar el contacto con la lengua de otras culturas.

Para cumplir el objetivo propuesto, consideramos necesario recurrir a las fuentes documentales inéditas del $\mathrm{AGN}^{31}$, A.H.P.B.A. y éditas, y en este último caso los aportes documentales de José Cignoli, y de Fernando Barba. Según los datos aportados por Fernando Barba, entre 1778 y 1810 habían ingresado a Patagones 409 empleados, siendo el promedio por año de $122^{32}$. Siguiendo a este autor el año 1784 fue el que contó con mayor cantidad de personal empleado por la Corona en este Fuerte: 149 personas. Decidimos tomar como referencia el ingreso de población que se supone alfabetizada ${ }^{33}$ a partir de 1778 hasta este año a efectos de establecer una variable que nos exprese cierto nivel de educación o grado de formación que podrían haber recibido en España y los calificaba para su función. En razón que carecemos de datos documentales que determinen en forma expresa - en esta primera etapa - si un individuo era analfabeto o no de alfabeto, seleccionamos a los individuos que fueron capaces de expresarse en forma escrita o de leer, producir o interpretar conocimiento.

El aporte documental de las obras de José Cignoli ha facilitado establecer el número y nombre de los cirujanos, practicantes, sangradores y sus fechas de ingreso al fuerte del río Negro o de Patagones ${ }^{34}$. Tanto el virrey Avilés ${ }^{35}$, como Hipólito Vértiz, este último a través del Semanario de Agricultura $^{36}$, no

${ }^{31}$ AGN, Sala IX, 18 de julio de 1788. Sala IX: Extracto de los oficios que remite Juan de la Piedra al Excmo. Virrey. En ellos informa sobre diversas cuestiones: idoneidad de las personas a su cargo, «solicitud de mujeres solteras qe. Puedan casarse con muchos que lo desean...», informe de la pronta salida de la expedición a la Sierra de la Ventana (31-12-1784).

${ }^{32}$ Barba, F. E. Op.cit., ANH. Buenos Aires, 1997, págs. 149-175.

${ }^{33}$ Bordieu, P.; Chamboredon, J.-P. y Passeron, J. C. El oficio de sociólogo. Presupuestos Epistemológicos, [s/1]: Siglo XXI, 2008, pág. 61. En este punto debemos recurrir a lo que llaman «las abdicaciones del empirismo», por cuanto la comprobación experimental de estos datos, no se pueden comprobar adecuadamente, por la inexistencia de interrogantes para y por los cuales no han sido construídos.

${ }^{34}$ Cignoli, F. «Cirujanos y Sangradores en la costa patagónica, durante el período hispano», Segundo Congreso de Historia Argentina y Regional, Academia Nacional de la Historia,Tomo I, Buenos Aires, 1974, págs. 95-107.

${ }^{35}$ Mariluz Urquijo, J. M. El virreinato del Río de la Plata en la época del Marqués de Avilés. (1799-1801), ANH, Buenos Aires, 1964, págs. 167-68. Durante el virreinato del marqués de Avilés, existió una clara política de avance sobre la costa patagónica ante las ambiciones británicas, tratando de establecer no solamente Patagones, sino San José Puerto Deseado y Malvinas.

${ }^{36}$ Vieytes, J. H. Antecedentes económicos de la Revolución de Mayo. Escritos publicados en el Semanario de agricultura, industria y comercio (1802-1806), Estudio preliminar Felix Weinberg, Buenos Aires: Raigal., 1956. En el Semanario escribe diversos artículos con los nuevos esfuerzos y descubrimientos científicos entre ellos sobre la vacuna de la viruela. n. ${ }^{\circ}$ 149, Tomo III, 24-7-1805; n. ${ }^{\circ}$ 150, Tomo III, 31-7-1805, Tomo III, 14-8-1805, n. ${ }^{\circ} 168$, Tomo IV, 4-12-1805. 
solo propiciaron la fundación de una fortaleza, sino el envío de empleados que tuvieran formación idónea para el establecimiento de un hospital ante los embates que sufrían los pobladores de diferentes enfermedades como el escorbuto y la difteria.

En las cuatro divisiones que se distribuyeron para la demarcación de los límites, del 26 de noviembre de 1783, cada una contaba con un cirujano, capellán y sangrador ${ }^{37}$. En la transcripción documental que realiza este autor sobre cirujanos y sangradores, queda determinado dos aspectos: primero, la categorización mayor que tenía el cirujano sobre el sangrador, quienes debían cumplir las órdenes de los primeros. Esta categorización estaba dada en la validación de títulos o exámenes a los que cada individuo se sometía. Tomamos como casos emblemáticos los de don Juan de Molina, integrante del cuerpo sanitario con dependencia del Real Tribunal del Protomedicato de Buenos Aires, Josef (José) Ungidos, designado el 11 de febrero de 1791 como sangrador del establecimiento por su «eficiencia, como igualmente del examen en teórica y práctica ${ }^{38}$. Las cuestiones medicinales, requerían, por cierto, de «conocimiento», «capacidad», «idoneidad», «destreza», «exámenes teóricos»y título habilitante, aspectos que están presentes en la nominación de estos cargos. La medicina virreinal alcanzó su más alto nivel durante el reinado de Carlos III y por ende, la incidencia que tuvieron los profesionales «en el arte de curar» en las nuevas empresas de la Corona ${ }^{39}$.

$\mathrm{Al}$ aporte documental ofrecido por los autores mencionados, consultamos la Lista de de los Asientos de los Empleados ${ }^{40}$, a efectos de cotejar y comparar las retribuciones recibidas entre estos profesionales del arte de curar dentro de la estructura organizativa de empleados establecidos en Patagones, con otros cargos que implicaban por sus labor, el conocimiento de la lecto-escritura. En primer lugar observamos que la lista aludida, diferenciaba por «clases» a los empleados de la Corona, según la tarea que cumplían. Buscamos establecer si esa diferencia se jerarquizaba en el salario que percibían por su idoneidad o por su capacitación basada en la cuestión de la lengua: por ejemplo, poder decodificar una Real Orden, una Real Cédula o realizar un informe a autoridad competente.

Dentro de estas categorías podríamos inducir que encontrarían en la categoría intelectuales: comisarios superintendentes, contadores, escribientes, capellanes, cirujanos, practicantes y sangradores, en cuanto a lo significativo de su función. No dejando olvidado que el salario no significaba — según Barba— una

${ }^{38}$ Anexo documental I, en Cignoli, F. Idem, pág. 104.

${ }^{39}$ Requejo, J. A. «La Organización hospitalaria en los tiempos del Protomedicato», Buenos Aires, Publicaciones del Departamento de Historia del Instituto Superior Dr. Arturo Jauretche. www.institutojauretche.edu.ar/ publicaciones/nota3html.

Avala esta afirmación lo sostenido por Parada, A. E. en «Libros de medicina en bibliotecas particulares argentinas durantes el período hispánico», Saber y tiempo. Revista de historia de la ciencia, . $^{\circ}$ 4, Biblioteca José Babini, Buenos Aires, julio-diciembre, 1997, págs. 463-468. Este autor que el relevamiento un notable incremento de autores y obras médicas a partir del siglo XVIII.

40 AHPBA Lista que comprende los Asientos de los empleados en el establecim.to del Río Negro. Costa Patagónica. Año 1778. 
realidad por la precariedad de medios en que desenvolvían su vida los habitantes de Patagones y la mora en que incurría la Real Hacienda para el pago efectivo de los salarios ${ }^{41}$.

\footnotetext{
${ }^{41}$ Barba, F. Op.cit. pág. 150.
} 


\begin{tabular}{|c|c|c|c|c|c|}
\hline Cargo & Nombre & $\begin{array}{c}\text { Fecha de } \\
\text { designación }\end{array}$ & Sueldo & Nivel de formación educativa & \\
\hline $\begin{array}{l}\text { Comisario } \\
\text { Superintendente }\end{array}$ & Juan de la Piedra & $1814 / 5 / 1778$ & $\$ 3500$ & $\begin{array}{l}\text { Biedma en sus obras realiza una } \\
\text { extensa biografía de su persona: en } \\
\text { ella se desprenden una tipología } \\
\text { independiente y autónoma en la toma } \\
\text { de resoluciones personales: «...sin } \\
\text { más consulta ni dictamen que el suyo } \\
\text { propio» }{ }^{42} \text {. Planea una población y } \\
\text { escribe una crónica }{ }^{43} \text {. Las } \\
\text { desavenencias con Francisco de } \\
\text { Viedma y las peticiones personales al } \\
\text { virrey, marcan una primacía de } \\
\text { objetivos individuales y valores que } \\
\text { refuerzan su independencia, el } \\
\text { conocimiento de la lecto-escritura }{ }^{44}, \mathrm{o} \\
\text { los oficios e informes remitidos }{ }^{45} \text {. }\end{array}$ & 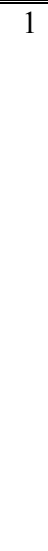 \\
\hline $\begin{array}{l}\text { Comisario } \\
\text { Superintendente }\end{array}$ & $\begin{array}{r}\text { Francisco de } \\
\text { Viedma }\end{array}$ & $\begin{array}{c}28 / 11 / 1778 \text { hasta } \\
\text { el } 26 / 1 / 1784\end{array}$ & $\begin{array}{r}\$ 3500 \\
\text { anuales }\end{array}$ & $\begin{array}{l}\text { Cabildo. Publicó un notable trabajo } \\
\text { estadístico de la provincia. En la } \\
\text { Descripción de la Costa Patagónica, } \\
\text { se observa el conocimiento explícito } \\
\text { de Crónicas de Viajes anteriores } \\
\text { (mediados del S.XVIII), de cartas } \\
\text { geográficas }{ }^{46} \text {, fauna y flora }{ }^{47} \text {. } \\
\text { Demuestra en su correspondencia con } \\
\text { el virrey identidad étnica con el grupo } \\
\text { que dirige, arraigo y pertenencia al } \\
\text { espacio. Proviene de familia notable } \\
\text { de Jaén, pero se adapta a la pérdida de } \\
\text { status original, facilitar relaciones } \\
\text { multiculturales }{ }^{48} \text {. }\end{array}$ & 2 \\
\hline
\end{tabular}

${ }^{42}$ Biedma, J. J. Apuntes..., 1887, pág. 11 y Biedma, J. Crónica ..., op.cit., pág. 253.

${ }^{43}$ Irarrázaval Larrain, J. La Patagonia. Errores Geográficos y Diplomáticos, Chile: Ed. Andrés Bello, 1966. Son claves las palabras de este autor, definiendo a de la Piedra: «Enemistado de la Piedra con los hermanos Viedma, recurre a la corte en solicitud de justicia...Francisco de Viedma, miembro de una de las principales familias de Andalucía y regidor de Jaén, donde disfrutaba de merecida consideración...» (Galvez) le preguntó en qué condición se hallaban sus tierras de Jaén, a lo que Viedma satisfizo expresándole que «a fuerza de cuidados y trabajos había logrado llevarlas a un estado de prosperidad extraordinarias». «Esto es precisamente lo que quiere el Rey que Ud. Haga en la Patagonia», pág. 36. Silva, H. (1978) lo define como «optimista» pese a los problemas con los Viedma y otros oficiales, a las dificultades que motivaron su queja ante el Rey sobre la falta de colaboración encontrada en el Río de la Plata, pág. 63.

${ }^{44}$ Entraigas, Op.cit., pág. 141.

${ }^{45}$ AGN, Sala IX, noviembre de 1784, «Solicitud de mujeres solteras qe puedan casarse...», «Solicitud del religioso Tadeo Gutierrez...».

${ }^{46}$ Furlong, G. «La Patagonia en la Cartografía Antigua y Moderna», Segundo Congreso de Historia Argentina y Regional, Tomo I, ANH Buenos Aires, 1974, pág. 171.

${ }^{47}$ Viedma, A. Diario de una viaje a la Costa de Patagonia, pág. 418.

${ }^{48}$ Entraigas, R. O. «La obra de Antonio de Viedma en la Patagonia», Segundo Congreso de Historia argentina y regional, ANH Buenos Aires, 1974, págs. 139-160. 


\begin{tabular}{|c|c|c|c|c|c|}
\hline \multirow[t]{3}{*}{$\begin{array}{l}\text { Escribientes o } \\
\text { Escrivientes } \\
\text { (libro de } \\
\text { empleados) }\end{array}$} & Pexicena Miguel & $\begin{array}{l}26 / 11 / 1778 \\
\text { hasta } 1810\end{array}$ & $\$ 20$ & $\begin{array}{l}\text { Intermediarios culturales e intérpretes } \\
\text { alfabetizados de la etapa colonial. } \\
\text { Funcionarios de menor rango. Su } \\
\text { oficio era copiar escritos ajenos o los } \\
\text { que se les dictara. Integran una } \\
\text { posición dentro de los «intelectuales } \\
\text { de tipo urbano o rural» por poner en } \\
\text { contacto a la administración local, } \\
\text { funcionarios políticos o militares con } \\
\text { artesanos o campesinos. Su distinción } \\
\text { está en ser especialistas en la } \\
\text { escritura }^{49} \text {. }\end{array}$ & 3 \\
\hline & Morgado Manuel & $\begin{array}{l}1 / 12 / 1778 \\
\text { hasta } 1810\end{array}$ & $\$ 20$ & & 4 \\
\hline & $\begin{array}{r}\text { Núñez José } \\
\text { Manuel }\end{array}$ & $\begin{array}{l}30 / 6 / 1784 \\
\text { hasta } 1810\end{array}$ & $\$ 20$ & & 5 \\
\hline \multirow[t]{3}{*}{ Capellanes $^{50^{-1}}$} & Giménez Pedro & $\begin{array}{c}4 / 8 / 1782 \\
\text { hasta } 6 / 12 / 84\end{array}$ & $\$ 30$ & $\begin{array}{l}\text { Religioso Orden Santo Domingo. Se } \\
\text { establecen en América a partir del } \\
\text { siglo XVI. }\end{array}$ & 6 \\
\hline & $\begin{array}{l}\text { Montañez } \\
\text { Francisco }\end{array}$ & $\begin{array}{c}24 / 4 / 1783 \\
\text { hasta } 30 / 4 / 1785\end{array}$ & $\$ 30$ & $\begin{array}{l}\text { Religioso Orden de la Merced. } \\
\text { Participa con Juan de la Piedra en la } \\
\text { excursión a Sierra Ventana donde es } \\
\text { tomado prisionero de guerra por los } \\
\text { indígenas, luego de la muerte de de la } \\
\text { Piedra }{ }^{51} \text {. Llega en el Bergantín La } \\
\text { Piedad y es nombrado en la fecha } \\
\text { citada. En el documento se lee que } \\
\text { por Decreto Superior del intendente } \\
\text { del } 6 \text { de junio de } 1789 \text {, todos los } \\
\text { capellanes de Costa Patagónica deben } \\
\text { disponer de } 4 \text { pesos diarios de } \\
\text { gratificación de ración sobre su } \\
\text { sueldo }{ }^{52} \text {. }\end{array}$ & 7 \\
\hline & Famago José & $\begin{array}{c}13 / 4 / 83 \\
\text { hasta } 6 / 12 / 84\end{array}$ & $\$ 30$ & $\begin{array}{l}\text { Religioso Orden de la Merced. La } \\
\text { orden de los mercedarios tuvo su } \\
\text { origen en Barcelona, siglo XIII. No } \\
\text { era una orden mendicante sino por } \\
\text { privilegio de la Corona, acompañaba } \\
\text { a ejércitos cristianos como capellanes } \\
\text { o vicarios castrenses }^{53} \text {. }\end{array}$ & 8 \\
\hline
\end{tabular}

${ }^{49}$ Gramsci, Op.cit., pág. 19. Esta especialización técnico-cultural del empleado estatal, logra para esta autor, una actitud contradictoria para el campesino, a quien lo admira, pero a su vez lo desprecia.

50 Zuretti J. C. Historia Eclesiástica Argentina, Buenos Aires: Huarpes, 1945. Este autor sostiene que los franciscanos Ramón del Castillo, Domingo Velazco y Tomás Nicolao, que acompañaron a Viedma y de la Piedra en la fundación de la ciudad de Patagones, tuvieron un papel dominante en la cuestión eclesiástica en la población, pág. 165 .

${ }^{51}$ Biedma, J. J. Cronica..., pág. 247.

52 AHPBA Lista que comprende los asientos de los Empleados de los establecimientos del Río Negro. Costa patagónica, año 1778.

${ }^{53}$ Morales Padrón «Historia General de América», Manual de Historia Universal, Tomo VI, [s/1]: Espasa Calpe, 1975, pág. 454. 


\begin{tabular}{|c|c|c|c|c|c|}
\hline & Giménez Tadeo & $\begin{array}{c}2 / 10 / 83 \\
\text { hasta } 2 / 2 / 1786\end{array}$ & $\$ 30$ & Religioso Orden de la Merced ${ }^{54}$. & 9 \\
\hline & $\begin{array}{r}\text { Bosques } \\
\text { Francisco }\end{array}$ & $\begin{array}{c}15 / 8 / 1784 \\
\text { hasta } 2 / 2 / 1786\end{array}$ & $\$ 30$ & Religioso Orden de la Merced & 10 \\
\hline & $\begin{array}{r}\text { Salvadores } \\
\text { Joaquín }\end{array}$ & $\begin{array}{l}15 / 8 / 1784 \\
\text { hasta } \\
2 / 2 / 1786\end{array}$ & $\$ 30$ & $\begin{array}{l}\text { Religioso de la Orden de los } \\
\text { Predicadores }\end{array}$ & 11 \\
\hline & Conio Pablo & $\begin{array}{c}26 / 12 / 1784 \\
\text { hasta } 29 / 10 / 1786\end{array}$ & $\$ 30$ & Religioso de la Orden de la Merced & 12 \\
\hline \multirow[t]{9}{*}{$\begin{array}{l}\text { Cirujanos, } \\
\text { Practicantes y } \\
\text { Sangradores }\end{array}$} & $\begin{array}{r}\text { Aguilera José } \\
\text { María } \\
\text { (Sangrador) }\end{array}$ & $\begin{array}{c}25 / 8 / 1781 \\
\text { hasta } 6 / 12 / 1784\end{array}$ & $\$ 20$ & & 13 \\
\hline & Lamela Francisco & $\begin{array}{c}11 / 6 / 1783 \\
\text { hasta } 29 / 10 / 1786\end{array}$ & $\$ 50$ & $\begin{array}{l}\text { Natural de Galicia, hijo de Francisco } \\
\text { y María Piñeiro. Estudió medicina en } \\
\text { Cádiz donde se recibió de cirujano } \\
\text { romancista, vale decir, hizo sus } \\
\text { estudios en lengua romance } \\
\text { (castellano) y no en latín. Apenas } \\
\text { graduado fue destinado a las } \\
\text { expediciones mandadas para poblar la } \\
\text { costa patagónica. Fue cirujano de Río } \\
\text { Negro y se ocupó de clasificar plantas } \\
\text { medicinales de la región para } \\
\text { mandarlas a España }\end{array}$ & 14 \\
\hline & Cormis, Juan & $\begin{array}{l}10 / 10 / 1783 \\
\text { hasta } 1810\end{array}$ & $\$ 60$ & Ayudante de cirujano mayor & 15 \\
\hline & $\begin{array}{r}\text { González Santa } \\
\text { Ana José }\end{array}$ & $\begin{array}{c}25 / / 5 / 1786 \\
\text { hasta } 5 / 11 / 1786 \\
(*)\end{array}$ & $\$ 50$ & $\begin{array}{l}\text { Cirujano-Sangrador (fecha }\left({ }^{*}\right) \text { de } \\
\text { fallecimiento) }\end{array}$ & 16 \\
\hline & Parri Ramón & $\begin{array}{c}26 / 10 / 1784 \\
\text { hasta } 17 / 11 / 1785\end{array}$ & $\begin{array}{r}\$ 6 \\
\text { gratificación }\end{array}$ & $\begin{array}{l}\text { Sangrador Soldado del Regim.de inf. } \\
\text { De Bs.As. }\end{array}$ & 17 \\
\hline & Pavón Martín & $\begin{array}{l}27 / 2 / 1782 \\
\text { hasta } 1786\end{array}$ & & $\begin{array}{l}\text { Cirujano del establecimiento de Río } \\
\text { Negro. }\end{array}$ & \\
\hline & Méndez Pedro & $\begin{array}{c}1 / 8 / 1783 \\
\text { hasta } 2773 / 1799\end{array}$ & $\$ 20$ & Poblador (practicante) 56 & 18 \\
\hline & Auca Ignacio & $1 / 12 / 1778$ & $\$ 15$ & $\begin{array}{l}\text { (se toman los nombres que figuran a } \\
\text { fs. 152) }\end{array}$ & 19 \\
\hline & Silva Juan & $6 / 9 / 1798$ & $\begin{array}{l}\text { \$10 más } \\
\text { ración diaria }\end{array}$ & & 20 \\
\hline
\end{tabular}

Fuente: Archivo Histórico de la Provincia de Buenos Aires. Lista que comprende los asientos de los empleados en el establecimiento del Río Negro. Costa Patagónica. y Barba, F. E. «Pobladores y empleados de Carmen de Patagones 17791810», Separata Sexto Congreso Nacional y Regional de Historia Argentina, ANH, Buenos Aires, 1997, págs. 147-176.

Tal como sostiene Peter Burke ${ }^{57}$ una de las mayores innovaciones, y a su vez controvertidos, métodos historiográficos es alcanzar la mayor seguridad y precisión con métodos cuantitativos. Siendo cons-

${ }^{54}$ AGN, Extracto de los oficios de Juan de la Piedra: «solicitud del religioso para ser relevado de este destino», noviembre de 1784. Los relevos de destino se debían comúnmente a problemas de salud provocados por el clima y las condiciones de vida.

${ }^{55}$ Udaondo, E. Diccionario Biográfico Argentino, Institución Mitre, Buenos Aires: Coni, 1938, pág. 556.

${ }^{56}$ AGN, Legajo M.19, Expte. n. ${ }^{\circ}$ 3, Catálogo de nombres, División Colonia.

${ }^{57}$ Burke, P. New perspectives on historical writing, Estados Unidos: Pennsylvania University, 1994, pág. 15. 
cientes, en este caso, del relativismo estadístico, nos atrevemos a sostener que tomando el año 1784, como el de mayor cantidad de empleados cuantificables y haciendo uso de las estadísticas aludidas, sobre un total de 149 personas, un 14,09 \% constituían la población instruida. No obstante, no se observa que hubiera existido una relación entre el salario-nivel de alfabetización salvo en los cirujanos con los comisarios superintendentes. Curiosamente los practicantes y sangradores, que requerían de estudios científicos previos o los capellanes, que habían sido educados en las órdenes respectivas, tenían un salario mucho menor que calafates, albañiles, herreros y aserradores. Indudablemente, la valoración de los salarios de estos últimos, tendieron a reconocer valores distintos a su capacidad en la lectoescritura sino al tecnicismo de su labor, la complejidad de su empleo y las aptitudes necesarias en una plaza vacía de oficios y plena de necesidades. Aunque no podemos ignorar que estos empleados requerían de conocimientos o habilidades que le permitían elaborar tejas, trabajar el hierro, vidrio, carpintería, etc. Estos oficios presuponen el conocimiento (no formal) de operaciones matemáticas, geométricas, físicas y hasta geográficas, en tanto la determinación de las mejoras tierras para cultivar.

En cuanto a estos últimos, si nos atenemos conceptualmente a Carlos Altamirano — traduciendo a Shils-, las tareas y el lugar de los intelectuales en una estructura social se define por las aptitudes de una minoría frente a las necesidades colectivas ${ }^{58}$. La llegada del Ingeniero José Pérez Brito ${ }^{59}$, el marino Basilio Villarino y Bermúdez reconocido «por su competencia» e «instruído», la presencia del Piloto José de la Peña, encargado de la construcción de 33 casas $^{60}$, permiten demostrar que toda práctica científica, así fuera de un empirismo radical, son la formulación del reconocimiento «al conocimiento». Las competencias culturales adquiridas por personalidades como estas, favorecieron la formación en la población de carpinteros, herreros, maestros tejeros, albañiles, conocimientos del cálculo, geografía y el dibujo.

d) El maestro: Solo podemos certificar hasta 1821, la presencia exclusiva de una sola persona que se atribuyó la función de «maestro»:

Juan Gómez de la Pinta, poblador de Río Negro, con la debida veneración dice: que habiéndose ejercitado, desde el año pasado de 1782 en la educación de la juventud de este destino, enseñándoles doctrina cristiana y primeros rudimentos y hallándose en términos de no poder subsistir en este ejercicio, sin alguna congrega, como se practica en Europa, suplica a V.S.

${ }^{58}$ Altamirano, C. Intelectuales. Notas de investigación, Buenos Aires: Norma, 2006, págs. 75-76.

${ }^{59}$ Pérez Brito, era ingeniero habiendo llegado al Río de La Plata con el virrey Ceballos se había desempeñado en diferentes obras de construcción de fortalezas en Montevideo, Buenos Aires y diseñó el plano del fuerte de Patagones. El testimonio de Biedma destaca que «fue tratado afablemente...considerada la necesidad que de sus inteligentes servicios sentía como un enviado providencial», pág. 103.

${ }^{60}$ Este marino es el encargado de confeccionar la Carta del Litoral Bonaerense. En: Ratto, H. R. Carta del litoral bonaerense comprendido entre el rio Colorado y Negro, Publicaciones del Instituto de Investigaciones Geográficas de la Facultad de Filosofía y Letras, Serie B, Documentos Cartográficos, Planimétricos e Iconográficos, Buenos Aires: Peuser, 1930. 
rendidamente, se sirva señalarle algún pre para su manutención, exponiendo del mismo tpo. Que de no ser asi, se ve obligado a renunciar a este cargo para buscar otro modo de vida... ${ }^{61}$.

Al carecer de mayor información sobre este poblador laico podemos inferir: primero, que sus intentos de educación formal han fracasado por no contar con el apoyo de una congregación religiosa que lo sostenga. Segundo, Que este individuo que figura como viudo en la relación que ofrece Biedma, no ha contado con sueldo ni es empleado de la Corona. Por ende, podemos afirmar que no consideraba el estado español obligación de sostener la educación de la población si no se era a través de órdenes religiosas. Posteriormente, la afirmación Manuel Álvarez en el prólogo de la Crónica de Biedma, es la denuncia concreta de la exigencia de formación educativa sistemática por parte de la población: «La educación de aquella juventud inteligente y bien dispuesta abandonada a la dirección de un preceptor aislado y sin modelos de enseñanza... ${ }^{62}$. La mujer condenada según sus palabras $-\mathrm{y}$ con algunas excepciones-, «a una perpetua ignorancia». Álvarez entiende que esta sociedad sin interés puede recuperar los valores correspondientes de una «raza» privilegiada aumentando su «cultura». El lenguaje de quien fuera juez de paz y educador a-sistemático de la población encierra en su vocabulario toda una filosofía de lo social que contiene palabras comunes como cultura-barbarie-civilización. Identifican el desarrollo de un cuerpo social, con la relación entre civilizado-educado.

e) D’Orbigny dirá años más tarde sobre Patagones: «Parece asombroso encontrar tantas personas distinguidas en un establecimiento, por así decirlo, y tan alejados de todos los recursos...». Esta población surgida por agricultores, colonos y deportados por crímenes o causas políticas, según este viajero, presentaba la dualidad de contar con un grupo de comerciantes españoles, como Álvarez y Alfaro, que sostenían una velada adhesión a la Corona y paralelamente mantenían vínculos permanentes con los grandes comerciantes de Buenos Aires. En este punto, podemos decir que existió una precisa separación entre el trabajo y la ciencia que se extiende al lenguaje. Estos comerciantes españoles conviven con agricultores, colonos y deportados por crímenes o causas políticas. Si seguimos la descripción del naturalista, la población del Carmen estaba conformada a principios del siglo XIX por un abanico de pequeños comerciantes secundarios de todas las naciones (franceses, ingleses, portugueses y sobre todo americanos) que convivían con algunos capitanes de corsarios de diversas naciones. «Estaban finalmente, los propietarios, primeros fundadores del establecimiento y las autoridades que allí residían a causa del comercio y

\footnotetext{
${ }^{61}$ AHN, IX-16-4-4, citado por Bellini de Curzio, M.; Bovcon, R.; Entraigas, J. R. y Suárez, G. Historia del Río Negro en documentos, Integrantes del Departamento Archivo Histórico Provincial, Centro de Investigaciones Científicas, Río Negro, 1977.

${ }^{62}$ Biedma, J. J. Op.cit. pág. 19. Juan Gómez de la Pinta, viudo, con tres hijos, figura con fecha de llegada a Ciudad del Carmen venido en la fragata «La Santísima Trinidad», el 5 de enero de 1782. Sala IX. Buenos Aires.
} 
de la importancia de la región» ${ }^{63}$. Como una isla del Virreinato, Patagones, pareció quedar según este último testimonio, ajena al anti-españolismo con que se procede después de la revolución de Mayo, en todo su territorio ${ }^{64}$. También Emir Reitano ${ }^{65}$, confirma que la influencia política y el poder económico de los españoles decae hacia finales del siglo XVIII. No obstante, a nuestro criterio no implicó que la transformación del mapa político del resto del virreinato, hubiera afectado a un asentamiento fronterizo, en lo que respecta a los instrumentos de dominio: el poder, las armas y el lenguaje.

\section{Patagones como espacio de aislamiento}

Esta nueva urbanización patagónica nació con un objetivo primario: proteger las líneas australes del territorio, a fin de evitar el emplazamiento de otras potencias europeas, en un sentido político estratégico. Según Hernán A. Silva, la ocupación del territorio, surge por «disposiciones comunicadas al Virrey del Río de la Plata en forma taxativa», por lo tanto, la misma fue limitada, circunscripta y reducida a una circunstancia, el peligro que anticipaba el libro del Padre Tomás Falkner ${ }^{66}$. Siguiendo a este autor, los primeros pobladores, habían respondido a una convocatoria de la Real Orden del 8 de julio de 1778. La fundación es contradictoria en sí misma, si nos atenemos a las palabras de Silva, ya que «los preparativos no eran coherentes con las fundamentaciones económicas de la empresa» ${ }^{67}$. Las instrucciones dadas al intendente de La Coruña, establecían que se reunirían familias «instruidas en las labores de campo» ${ }^{68}$, quienes, paradójicamente, deberían venir a sostenerse con la pesca y la fábrica de aceite de ballenas ${ }^{69}$. Si, por otra parte, tenemos en cuenta que estos inmigrantes castellanos provenían de una zona de llanuras, campiñas o páramos de grandes diferencias paisajísticas opuestas al espacio a colonizar y eran fundamentalmente agricultores y artesanos, permite reflexionar acerca del significado que Silva le otorga a esta inmigración. Si la misma fue «taxativa», — según se desprende del objetivo de

63 Dorbigny, A. Viaje a la América Meridional realizado de 1826 a 1833, Brasil, República del Uruguay, Republica Argentina, la Patagonia, República de Chile, República de Bolivia, República de Perú, [s/1]: Futuro. 1945, pág. 32.

64 León Matamoros, M. G. «El conflicto de los españoles ante el proceso de emancipación. Los casos del Río de la Plata y México en los albores del siglo XIX», Anuario del Instituto de Historia Argentina, n. ${ }^{\circ}$ 10, Facultad de Humanidades y Ciencias de la Educación. Universidad Nacional de La Plata, 2010, págs. 15-36.

65 Reitano, E. citado en León Matamoros, pág. 17.

66 Silva, H. A. La economía pesquera en el Virreinato del Río de la Plata, Buenos Aires: FECIC, 1978, pág. 60.

67 Ibídem, pág.61.

68 Ibidem, pág.61.

69 Nota: Si tenemos en cuenta las palabras de Goyret, tanto las personas reclutadas en huestes y milicias por parte de España, como sus primeros pobladores, «tenían muy mala fama», respondiendo muchos de ellos al hambre y la miseria que sufrían en la Península. Este autor, sostiene que «los capitanes ni legales ni éticos para lograr el reclutamiento». Goyret, J. T. «Huestes, milicias y ejército regular», Nueva Historia de la Nación Argentina. Período español. (1600-1810), ANH, Tomo 2, Buenos Aires, 1999, pág. 357. 
la empresa - no respondería a una acción estrictamente voluntaria, sino fueron, según esta reflexión, objetos de un programa de control económico y fronterizo ${ }^{70}$. En este caso, estos inmigrantes ejercerían - según las estructuras de poder que ocuparán posteriormente - mecanismos de control de la población, con sistemas propios, surgido en Europa hacia la segunda mitad del siglo XVIII y luego adoptados por España.

La vigilancia de las costas sería recompensada con una mejoría en su sistema de vida, y como en una contradicción del destino, de aquellos individuos que hasta allí llegaran como los presidiarios y esclavos. Algunos y sus descendientes se convertirán sin distinción de sexos, en los garantes de la seguridad de una nueva urbe al participar como milicianos, jueces de paz, educadores y hasta policías, con activa participación en los sucesos de marzo de $1827^{71}$. Este sistema irá modelando una nueva sociedad, donde paradigmáticamente, van desapareciendo estructuras de poder y la verticalidad unilateral del poder soberano, aparece como difusa, al no ser visible un eje rector.

En alusión a las cuevas donde vivieron algunos de estos españoles al principio, Mariluz Urquijo, considera que ha existido cierta exageración sobre «...las penalidades sufridas por estos trogloditas del siglo XVIII» ${ }^{72}$, aunque destaca la existencia de un contrato con la Corona cuyo primer objetivo era demostrar «voluntad de dominio»y frenar las ambiciones británicas. Para este autor, las cuevas resultan, contrariamente a lo estimado, lo suficientemente acogedoras para aquel que por su condición social es destinado al desván del virreinato.

Fernando Barba ha estudiado este sistema de vivienda al que tuvieron que recurrir los maragatos en los inicios de la fundación de Patagones. A través de documentos del Archivo General de la Nación, reconoce el papel que le cupo a José de la Peña en la construcción de las casas prometidas por las autoridades virreinales: «...de la Peña, solicitaba al virrey (1798) que se ordenara al Comandante de Río Negro que no se cortara más sauce hasta que él no llegara a aquel destino, y que no se continuara construyendo ningún edificio» ${ }^{73}$. La propuesta virreinal a este piloto de la Real Armada, pretendía sacar a los vecinos de estas cuevas a la vera del río, aunque primó la reparación de edificios como el almacén de víveres, del puerto de San José, la capilla, edificio del fuerte y tahonas de Patagones, cuyos techos estaban hasta ese momento cubiertos con cueros. Reconoce Barba que las falta de colaboración, tanto en mano de obra como de materiales por parte de Fermín Indart a cargo de la Junta Superior de la Real

${ }^{70}$ Biedma (1905) no se puede negar la existencia de «maragatos» entre los primitivos pobladores de Patagones. Desde el punto de vista religioso le atribuye cierta independencia del catolicismo, dado su origen berberisco. Tal vez responda a la visión de una iglesia caracterizada por prácticas irregulares y causal de división entre las familias, pág. 91.

${ }^{71}$ Ramírez, M. S. «Vinculación entre el Ejército de Campaña y la extensión de la educación elemental (18231869)», en: Cernadas de Bulnes, M. (comp.) Historia, Política y Sociedad en el Sudoeste Bonaerense, Bahía Blanca: Ediuns, 2001, págs. 399-412.

${ }^{72}$ Mariluz Urquijo, J. El Virreinato del Río de la Plata en la época del Marqués de Aviles. 1799-1801, ANH, Buenos Aires, 1964, págs. 167-68.

${ }^{73}$ Barba, F. E. Op. cit., 1996, pág. 137. 
Hacienda $^{74}$ y del cirujano Juan Maestre, habrían agravado la situación y resentida la construcción de la casas por no contar con personal idóneo.

El patrimonio edificado — en tanto patrimonio cultural — no es un bien neutro sino con valores y sentido fijo en su interpretación. Es un producto cultural que se transforma, se renueva, se resinifica, y son indicadores de pequeños logros de la vida cotidiana. Podemos afirmar que en este punto, Patagones aparece en el momento de su fundación como espacio común recortado e inmóvil constituyendo una vigilancia organizada, necesaria por una preocupación política y económica de la Corona. Si bien, estos españoles no son víctimas de punición ni de falta de libertad como bien absoluto, la confinación y el aislamiento surge como una contradicción interna de la Corona sobre la correlación entre el poder y el status económico ${ }^{75}$.

Carlos María Gorla sostiene que Patagones, como centro urbano de avanzada en la Patagonia, genera en su población maragata, por la constante amenaza del indígena, «...la responsabilidad de asumir la defensa del establecimiento, lo que fue forjando en ella un sentimiento de solidaridad colectiva,...» ${ }^{76}$.

Silvia Ratto, coincide con Gorla que esta fundación es una avanzada «...del territorio blanco en una zona totalmente aislada del resto de la provincia» ${ }^{77}$. Tomando en cuenta las dimensiones culturales con que se definen los procesos emigratorios Hofstede y Páez, presuponemos que sostienen ambos autores existieron factores como «emigración forzada»y «distancia de poder» ${ }^{78}$. Ellos surgen como determinantes que conformaron una sociedad particular y permitieron el asentamiento de actores de una «posición social relativamente precaria en su país de origen», pero, en cuyo traslado existió la esperanza propia de todo emigrante: mejorar su nivel de vida. Situación que refuerza las relaciones intergrupales y la «generación de mayores espacios de socialización», obviando el status social originario ${ }^{79}$. Estos parámetros socio-culturales provocaron que para sostener su supervivencia, debían generar un sistema lógico en lo político y económico: «La necesidad de una relación pacífica con las tribus circundantes, sumado al hecho de la lejanía de Patagones del centro político provincial, permitió que los funcionarios del fuerte en ocasiones, ignoraran o pasaran por alto disposiciones políticas de Buenos Aires...» ${ }^{80}$.

${ }^{74}$ Se desempeñaba como Contador desde el 12-9-1792. En Barba, F. Op. cit., 1997, pág. 160.

${ }^{75}$ Murgo, A. A. y Casanueva, M. L. Arqueología Histórica de Carmen de Patagones, página web Patagones. Facultad de Filosofia y Letras, UBA, 2007. En cuanto a la funcionalidad de las cuevas de los maragatos, las autoras plantean la hipótesis que no solo fueron utilizadas como habitaciones sino también como escondijos para animales.

${ }^{76}$ Gorla, C. M. «La Frontera de Patagones en el período 1820-1840», Investigaciones y Ensayos, n. ${ }^{\circ} 47$, ANH, $^{4}$ Buenos Aires, 1997, pág. 409.

77 Ratto, S., en: Mandrini, R. J. Relaciones interétnicas en el Sur bonaerense 1810-1830, UNS-UCPBA, Bahía Blanca, 1998, pág. 38.

${ }^{78}$ Paez, D. y González, J. L. «Culture and social psychology», Psicothema, Volumen 12, University of the Basque Country, University of Burgos, 2000, págs. 6-15.

${ }^{79}$ Hofstede, G. Cultures and organization, Londres: Mc.Graw, 1991, pág. 63. Páez, D. «Cultura y conocimiento de sí en España e Iberoamérica», en: Nieto, C. Saber, sentir y pensar, Madrid: Debate, 1997, pág. 216.

${ }^{80}$ Ratto, S. Op.cit., págs. 38-39. 
Claudia Iribarren, también puntualiza los problemas de distancia, comunicación, escasez de alimentos, y los determinantes como clima y la falta de agua potable, indicativos en la fundación del Fuerte del Carmen ${ }^{81}$.

Adriana Araque, centraliza su investigación en el contacto de los afro-hispanos en este centro urbano, y la construcción de una sociedad con claras divisiones en la organización de estos grupos en la vecindad y su posición en jerarquías administrativas, de defensa o vinculados exclusivamente a las actividades económicas primarias (panaderos, confiteros, servidumbre). Sin embargo, y siguiendo esta autora, aquellos grupos de inmigrantes de bajo status y fenotípicamente diferentes - como la población negra - refuerzan relaciones ligeramente favorables con los españoles tomando como ejemplo el caso de un negro rescatado de los indios y convertido en lenguaraz de Francisco de Biedma ${ }^{82}$. Esta última tendencia en determinada población negra, desarrolla una identidad cultural positiva, como intermediarios culturales que en este contexto social adquieren un patrimonio personal e intelectual como procesadores en la traducción de otros idiomas. Esta habilidad acabará con formas de alienación de su propia clase y los emancipará, al mismo tiempo, por la necesidad que sus opresores tienen de él.

Para Fradkin, «la coerción estatal... acrecienta no solo su fuerza armada sino su capacidad de controlar, vigilar, castigar» ${ }^{83}$. Esta coerción, para el autor, no solo juzga sino cambia los hábitos de su población.

Como segundo paso, conviene detenerse en el análisis de las expresiones o usos de frases determinadas de quienes participaron en la empresa colonizadora o como testigos. Presentaron a la iniciativa real, más que un acto voluntario de marinos aventureros, el sumiso cumplimiento de una orden real precisa $^{84}$.

El discurso que produce José J. Biedma, está constituido por afirmaciones categóricas sobre el origen de la misión de su antecesor, en cuanto sostiene que el fundador Francisco de Viedma, había respondido a las órdenes emanadas del ministro de Indias de Carlos III, y que esta fundación de orden político estratégico respondía «precisamente (a) lo que quiere el rey» ${ }^{85}$, a pesar que Juan de la Piedra, vaticinaba el fracaso de la empresa ante la escasa colaboración de las autoridades virreinales ${ }^{86}$.

${ }^{81}$ Iribarren, C. «Consideraciones Generales acerca de los indios y negros en el Fuerte del Carmen», Estudios Socio económicos del Sur Argentino, n. ${ }^{\circ}$ 1, UNS, Dpto. Humanidades, pág. 3.

82 Araque, A. «Contacto afro-hispanico en la comarca Viedma-Carmen de Patagones: relaciones Sociales y fórmulas de tratamiento», en: Hipperdinger, Y. (comp.) Contacto de Lenguas en el Sur Argentino, Departamento de Humanidades, UNS, Bahía Blanca, pág. 173.

${ }^{83}$ Fradkin, R. O. El poder y la vara. Estudios sobre la justicia y la construcción del Estado en el Buenos Aires Rural, Buenos Aires: Prometeo, 2007, pág. 26.

${ }^{84}$ En este punto es importante recordar el análisis que realiza Francisco Morales Padrón, sobre la Esencia del Conquistador, en Manual de Historia Universal, «Historia General de América», Tomo VI, 2a. edición, Madrid: Espasa Calpe, 1975, págs. 271-273, teniendo en cuenta la diferencia de estas expediciones, ahora muchas de ellas científicas y en este caso estratégicas.

${ }^{85}$ Biedma, J. J. Crónica histórica del Río Negro de Patagones, Buenos Aires: Contes, 1905, pág. 107.

${ }^{86}$ Cignetti, A. M. La Inmigración española en la Patagonia, Volumen IV, OEA, IP Geografía e Historia, 1989, pág. 14. 
En una obra previa, José J. Biedma, manifiesta que «el itinerario estaba trazado y poco, muy poco, tardaron aquellos leales vasallos en lanzarse a la empresa que les designaba su rey y señor» ${ }^{87}$. En páginas posteriores, sostendrá que entre 1781 a 1782 existió un real abandono de la Corona por los establecimientos de la Costa Patagónica.

Antonio de Viedma, en 1780, critica la política llevada a cabo por la Corona con respecto a la colonización patagónica, poniendo el acento sobre el aislamiento al cual estarían condenados sus habitantes: «Se lisonjeó la Corte de España de alejar de estos mares a las demás naciones; le parecía posible monopolizar su comercio, y afianzar de este modo el estado de aislamiento á que condenaba sus colonias» ${ }^{88}$. Pero, en referencia a estos «ensayos de colonización» como el mismo Viedma llama, no dubita en calificar que

...conspiró contra la existencia de estas colonias la veleidad de sus administradores: poco después de haber sido reconocida su oportunidad, el virrey Vértiz y el intendente Sanz opinaron que debían ser abandonados, y este consejo, adoptado por la Junta de Estado de Madrid no dejó en pie más que el presidio aun existente en la margen interior del Río Negro ${ }^{89}$.

Francisco Pita, descendiente de Bernabé Pita, poblador y fundador del fuerte del Carmen, transcribe la Real Cédula de Carlos III concedida a los primeros pobladores «por honrar a las personas, hijos y descendientes lexitimos de los que se obligasen a hacer... y cumplido su asiento les haremos hijos Dalgos y personas nobles de linaje...» ${ }^{90}$. El hablante pretende desarrollar argumentativamente juicios valorativos que fortalezcan el prestigio social de sus antepasados y que servirían de soporte a su actual status. Podemos interpretar esta afirmación como una pretensión de dar validez al prestigio que tenía en el momento de la presentación de su obra. En esta sociedad cuyos fundadores y colonizadores provienen de fuertes bases agrarias y sus esfuerzos de adaptación a las condiciones naturales, intentan protegerse teniendo su apoyo en la jerarquía social de sus primeros habitantes, a tal punto, que las vicisitudes iniciales se ven, paradójicamente, como positivas:

...que hermoso resulta a sus hijos recordar aquellas estrecheces, aquel aislamiento, aquel peligro, que contribuyó a que se formara allí una raza especial y fuerte, que creció y permaneció asi ${ }^{91}$, por espacio de un siglo, formando una sociedad aparte y haciendo vida de verdadero comunismo bien entendido.

${ }^{87}$ Biedma, J. J. Apuntes históricos del Rio Negro seguidos de una brevisima reseña de su más importantes pueblos, Viedma, 1887, pág. 10.

${ }^{88}$ de Viedma, A. «Diario de un viaje a la Costa de la Patagonia para reconocer en donde establecer poblaciones», en: De Angelis, P. Colección de Obras y Documentos relativos á la Historia Antigua y Moderna de las Provincias del Río de la Plata, Tomo V, Buenos Aires: Lajouane, 1910, pág. 415.

${ }^{89}$ Ibídem, pág. 418.

${ }^{90}$ Archivo Histórico de Carmen de Patagones, en apéndice de Pita, F. (escribano). «Remembranzas», Patagones, 1925.

${ }^{91}$ Ibídem. 
En este abanico historiográfico y documental, hemos debido obviar a otros autores que han analizado el tema fundacional de Patagones, por razones de extensión del trabajo, y para abocarnos al nudo central del mismo. En síntesis, tanto en los argumentos de la primera y de la segunda parte, existe un discurso que deja en claro elementos que permiten establecer paráfrasis interpretativas que nos acercan a la lógica foulcouniana de una sociedad de encierro y aislamiento que a su entender presentan las sociedades en ese momento histórico ${ }^{92}$.

La emigración de las familias castellanas fundadoras aparece - más que por atracción a una vida mejor-, como respuesta a una orden real que sugeriría una emigración semiforzada.

La población, de sectores sociales afectos por mecanismos de poder, será instrumento de una velada reclusión: formas de vida precarias y escasez de posesiones materiales. La vivienda es un componente contradictorio entre la visión historiográfica y como objeto simbólico constituye una unidad en la diversidad de las materializaciones culturales rioplatenses. La arquitectura no es un dato menor: en una sociedad panóptica existe una preeminencia del espacio en relación a la ubicación de la persona: los espacios exteriores para la demostración de la fuerza (a veces militar), de contacto social y multicultural y los interiores (las cuevas) que escapan al disciplinamiento externo, y permiten el desarrollo de las relaciones familiares vinculares.

El fin en sí mismo de esta empresa convirtió al emigrante, en «controlador» del poder real ante un posible conflicto. Y contra su primaria voluntad, el vínculo con otras culturas (indígenas y afroamericanas), su identidad étnica fue minoritaria, provocando aislamiento e incertidumbre sobre la seguridad de su persona y familia. Las convicciones son individuales alejadas de las convenciones del poder central.

La respuesta de este nuevo habitante es propio de un multiculturalismo interactivo, con amplia fusión grupos étnicos y de diferentes estratos sociales, generando mayores espacios de socialización. Pero sus herramientas educativas y socio-económicas, les permitirán posicionarse en el futuro en una redes familiares con dependencias y clientelas en lo político, económico y cultural de la población.

Consideramos por tanto como conclusión parcial, que estos «maragatos», o castellanos, para generalizar, formarán un espacio de distribución diferencial de población, en el cual se cumplen dentro de la lógica foucaulniana una sociedad de rasgos panópticos en el territorio bonaerense ${ }^{93}$.

¿Por qué nos atrevemos a esta última aseveración? Sin excluir el debate propio de nuestra reflexión, hemos observado que quienes participaron de la empresa de la fundación de Carmen de Patagones,

${ }^{92}$ Foucault, M. Dicho y escrito, Tomo II, [s/1]: Gallimard, 1994, pág. 319. Según este autor, sobre fines del siglo XVIII, surgen tres o cuatro tipo de sociedades según el modo de eliminar a sus «vivos» no a sus muertos: las que exilan, las que reparan, las que torturan o matan y finalmente las que encierran. Este encierro tiene la función tanto de arraigar geográficamente a los errabundos como a quienes debe sancionar por sus actos.

${ }^{93}$ Foucault, M. La verdad y las formas jurídicas, BuenosAires-Barcelona: Gedisa, 2005. El concepto de panóptico, constituyó una forma ideal de penalidad que este filósofo francés rescata, en una lectura personal, original y genealógica del pensador inglés Jeremy Bentham, del Panopticom, como proyecto de cárcel del siglo XIX, en su pasión por el estudio de la reclusión y de los sistemas punitivos. 
conformaba una tripulación de 232 personas de las cuales 50 eran presidiarios y 16 negros-esclavos ${ }^{94}$, por lo tanto, un 39,75\% de su población carecía de libertad desde su condición jurídica. Por otra parte, el espacio al que son destinados (tanto libres como presidiarios o esclavos) estaba localizado en un punto geográfico considerado de antemano como de «aislamiento». Este recibirá por parte de sus primeros pobladores un acondicionamiento urbano propio, si tenemos en cuenta las condiciones primarias de los espacios interiores.

A pesar que estos gallegos y castellanos, no pertenecían a estamentos sociales altos en su país de origen, ocuparán rangos militares, educacionales y jerárquicos de poder definido como gobernadores, alcaldes maestros, comandantes ${ }^{95}$, favorecidos por su conocimiento en estrategias como leer y escribir. Las mismas son los dos polos imprescindibles de la comunicación y a su vez la llave de la libertad: «El acto de escribir es un acto de libertad que llama a la libertad del lector» ${ }^{96}$.

En tanto los contadores, cirujanos, herreros, administrativos y lenguaraces, que integraban el resto de los futuros pobladores, funcionaron por la producción de sus saberes técnicos en este núcleo urbano, siendo constructores de una sociedad jerarquizada por sus aprendizajes, pero a su vez conservadora de sus imágenes y tradiciones, obteniendo con ello, legitimidad de dominio en un futuro próximo.

\section{La Fortaleza Protectora Argentina (1828)}

\subsection{La frontera como expansión como espacios de comunicación interétnica}

La fundación de la Fortaleza Protectora Argentina realizada en 1828, fue el efecto de nuevas formas de ocupación del espacio bonaerense constituyendo la tercera oleada de colonización fronteriza iniciada a fines del siglo XVIII ${ }^{97}$. En este avance fronterizo iniciado desde los partidos del norte bonaerense, existen diferentes y valiosos trabajos de investigación que han observado como la migración paulatina de familias hacia el sudoeste no estuvo exenta de las particularidades culturales que se generaban en el encuentro de una nueva cultura. En este marco los actores con estrategias o saberes más desarrollados, planteaban situaciones de jerarquía entre la cultura dominante y la dominada original.

Desde el punto de vista antropológico, existe una pregunta que ha sido formulada una y otra vez. Y se refiere al encuentro de distintos grupos humanos, algunos de ellos transitando una cultura paleolítica, cazadores-recolectores que obtenían lo necesario para la sobrevivencia y otras, en un estadio superior, seminómadas. Pero, que por otra parte, sostenían lazos de unión lingüística y de apropiación simbólica que los mantenía en contacto y permanente comunicación. Pero que ocurría en el encuentro de estas

94 Silva, H. A. Proceso colonizador en la región patagónica en la etapa virreinal, Universidad Nacional de Tucumán, 1982, pág. 11.

${ }^{95}$ Silva, H. A. Ibidem; Entraigas, R. El fuerte de Río Negro, Buenos Aires: Lib. Don Bosco, 1960, pág. 201.

${ }^{96}$ Altamirano, C. Intelectuales. Notas de Investigación, Buenos Aires:Norma, 2006, pág. 38.

${ }^{97}$ Banzato, G. y Lanteri, S. «Forjando la frontera. Políticas públicas y estrategias privadas en el Río de la Plata, 1780-1860», Historia Agraria, n. ${ }^{\circ} 43$, Murcia, diciembre, 2007, págs. 435-458. 
culturas con otros grupos humanos en un punto histórico crucial como era el viaje de culturas de mayor poder de traslación? En primer lugar, existió — como sostiene Krotz - un «problema cognitivo», según el testimonio dejado por viajeros: guerreros, comerciantes, exploradores, misioneros, marineros. El paso decisivo según esta reflexión era ver a otros seres humanos como «otros». Estos indígenas aparecen distantes, a pesar de su cercanía, por las imprecisiones de las culturas de donde provenían. Estos viajeros dejaron impresiones de alto valor documental sobre estas culturas: no solo sus giros lingüísticos que aumentaba sus dificultades de comunicación sino por su vestimenta, armamentos, costumbres y ritos religiosos ${ }^{98}$. Nació - por ende - una profundización en el contacto y encuentro de dos grupos culturales diferentes: grupos sociales seminómadas, con capacidad de habla y pensamiento orientado al modo utilitario y otro como parte de una sociedad organizada. Entiendo a este último punto, la existencia de una forma de dominio simbólico — en un contexto histórico — donde el iniciador del avance de frontera es poseedor del traslado, el caballo y del arma, de un corpus legal e instituciones que norman y el poder político virtualmente organizado. Por cierto, sostiene Habermas que nos vemos en la necesidad de remitirnos al lenguaje y la comunicación como forma peculiar de explicar el status por el que los pensamientos se distinguen de las representaciones: los miembros de una comunidad de lenguaje han de partir que hablantes y oyentes se van a entender de forma idéntica. Suponen que las mismas expresiones mantienen el mismo significado para ambas culturas ${ }^{99}$. La tradición neokantiana (Humboldt-Cassirer) estudió previamente los diferentes universos simbólicos, mito, lengua, arte, ciencia como instrumentos de conocimiento reconociendo el aspecto «activo» del que este cumple en una sociedad ${ }^{100}$. Bordieu ratificando este pensamiento formula que el instrumento metodológico que permite entender una cultura es la lengua como forma de inteligibilidad del habla y las funciones políticas que la misma cumple: la cultura dominante asegura a través de ella una comunicación inmediata entre todos sus miembros, pero a su vez, esta integración ficticia, legitima distinciones ${ }^{101}$. Por todo ello, entendemos que en el análisis de la frontera se generan no solo vínculos socio-económicos de expansión estatal, sino prácticas comunicativas interculturales que tendrán trascendencia como procesos de aprendizaje, que legitimará a las culturas dominantes por la tenencia del habla.

El tema de la frontera y su avance, ha sido estudiado por distintos historiadores quienes han dado diferentes interpretaciones en lo referente a la ocupación del suelo, poblamiento y frontera. Siendo uno de los iniciadores Frederick Jackson Turner ${ }^{102}$. Alvaro Jara hace alusión al problema en la interpretación de la ocupación del suelo, el poblamiento y frontera son conceptos sugerentes. Todos pueden ser utilizados como formas interpretativas de fenómenos históricos. No obstante cada una de las partes constituye sólo un sector de la verdad sino se la integra a las otras. En América Española la ocupación de la tierra y el poblamiento estuvieron condicionados a las características señoriales de la conquista,

98 www.uam. antropología.info/alteridades/alt8-1-Kratz, 1994, pág. 8.

99 Habermas, J. Facticidad y validez, Madrid: Trotta, 1998, pág. 73.

100 Cassirer, E. Antropología filosófica, 17 edición, México: Fondo de Cultura Económica, 1997, págs. 101-123.

101 Bordieu, P. «Sobre el poder simbólico», Intelectuales, política y poder, 2da reimpresión, Buenos Aires:

Eudeba, 2003, págs. 68-69.

102 Turner, F. J. The frontier in American History, Nueva York: [s/e], 1958. 
sujeta al financiamiento privado. Este sistema señorial buscó sus cauces al sistema de premios al conquistador: la merced de tierras fue complementado por el trabajo forzado de indígenas ${ }^{103}$.

Eric Von Young, en su estudio sobre la Historia rural mejicana desde Chevalier, analizó las múltiples relaciones económicas y sociales que surgen de un campesinado alejado de los centros urbanos, cuya principal producción está en la tierra. Establece además, las limitaciones que existe en realizar una división cronológica surgida de periodizaciones convencionales, que pretendieron marcar la historia rural de Méjico y de Latinoamérica en dos: la etapa colonial y la posterior a 1810. Una de las razones que esgrime es la supervivencia de estructuras económicas y culturales que corresponden a un tardío pero fluorescente imperio colonial. En este trabajo Von Young nos aporta métodos y fuentes para una historia social, vinculadas con teorías antropológicas y las influencias de culturas europeas en espacios de frontera, las ideas y fuerzas de conflicto y cohesión. Lo que este autor denomina Sectoral history (Historia regional) nos permite acercamientos analíticos cuando uno es completado por ejemplo con otras, a pesar de las dificultades que presenta ante la manipulación de grandes y heterogéneos cuerpos de datos. Pero las ventajas que presenta son varias. Primero, nos facilita una mirada de segmentos y sistemas en sociedades rurales, lo cual puede significar que determinadas regiones presenten cualidades sui generis. Segundo, la historia regional permite examinar las complejas relaciones entre ciudades y sus hinterlands. Con lo que podemos inferir, que nos facilitará conocer el porqué y la naturaleza del crecimiento o no de grandes centros urbanos ${ }^{104}$.

François Chevalier hace más de cuarenta años atrás pretendió establecer la idea de la hacienda mejicana como hábitat de hombre rico y poderoso, concretando una imagen del latifundio que se extendió rápidamente a diferentes historiadores. No obstante surgieron cuestiones y polémicas sobre la estructura institucional y el sistema de trabajo de la hacienda Mexicana. Apuntó al descuido de estudio por parte de los historiadores a la administración de ciudades y pueblos, su existencia cotidiana, su quehacer diario y sus vínculos con la autoridad y en su estudio en las luchas entre liberales y conservadores, consideró necesario tener en cuenta el protagonismo que tuvieron artesanos, mestizos, pequeños comerciantes y empleados en estos conflictos políticos nos proveyó un tableau vivant que nos sugiere una etiología para el estudio de las sociedades de diferentes poblaciones en distintos puntos de la frontera en México colonial. Con posterioridad Woodrow Borah, con algunas diferencias conceptuales en cuanto al estudio de las sociedades agrarias, se sumó con su tesis a los argumentos de Chevalier. Si bien ambas teorías no fueron compatibles, fueron complementarias, en cuanto al escenario de la historia de la sociedad agraria de México en el siglo XVII. Ambos proveyeron explicaciones sobre la historia rural de México desde la conquista de España: el dominio de un amplio e improductivo territorio de tierras del estado con una estructura social patriarcal o feudal, y fuerzas de trabajo serviles. La hacienda y el peonaje fueron el resultado de la depresión y el retroceso económico de Méjico.

103 Jara, A. «Ocupación, poblamiento y frontera», en: Jara, Á. (ed.).Tierras Nuevas. Expansión territorial y ocupación del suelo. (siglos XVI-XIX), México: El Colegio de Méjico, 1969, págs. 1-10.

104 Von Young, E. «Mexican rural history since Chevalier. The historiography of colonial hacienda», Latin American Research Review, 18:3, 1983, págs. 5-61. 
Gibson tomando el empirismo histórico ecléctico analizó la historia rural mejicana y las diversidades regionales que se observaban en las estructuras actuales del valle de Méjico. Las grandes diversidades sobre el modelo de Chevalier es que se detiene no sobre extensas e inutilizables estados sino sobre el rango en el tipo de variaciones de las haciendas según el tipo y el valor de su capital. Gibson encuentra puntos económicos no autárquicos que mantienen cercanos vínculos y pequeñas conexiones con mercados regionales y a su vez, vínculos de comercialización de estados con lo grandes comerciantes de la ciudad de Méjico. Al igual este autor analiza los sistemas de los peones rurales en relación con los hacendados, el estado y seguridad de la mano de obra indígena ${ }^{105}$. Tanto Gibson como Chevalier instalaron algunas imágenes divergentes sobre el análisis de la hacienda colonial, pero metodológicamente impulsaron el debate sobre la naturaleza y el desarrollo de sociedades agrarias como piezas partidas de un todo.

Raúl Mandrini es uno de los historiadores de nuestro país que ha realizado múltiples estudios sobre la frontera indígena en el área pampeana. De indudable consulta, nuestro propósito busca definir con mayor precisión a la misma. Considera a la frontera como «espacio social que se conforma históricamente y en el cual se articulan relaciones económicas, sociales y políticas particulares,...» ${ }^{106}$. Es posible hablar de frontera como «espacio de contacto» entre dos sociedades. Frontera como límite o separación existe - para Mandrini - en cuanto separa, en cuanto cumple la función de dividir dos sectores. Implica necesariamente la existencia de dos actores distintos. La frontera es un espacio partido pero también lo es compartido. Los intentos de avance fronterizo planteados a partir de 1810 desde principios del siglo XIX hasta la sexta década de del siglo XIX estuvieron signados por su carácter fundamentalmente ofensivo. Modelos de una expansión territorial vinculada a los intereses de la élite provincial en las actividades pecuarias.

Para Barsky y Djersteredjin la frontera indígena fue para los criollos una realidad tangible en la mayor parte del siglo XIX, ante relaciones de extrema tensión que buscaban por un lado el control indígena y

${ }^{105}$ Gibson, C. Los aztecas bajo el dominio español. 1519-1810, Buenos Aires: Siglo XXI, 1991.

106 Mandrini, R. «Frontera y relaciones fronterizas en la historiografía argentino-chilena», a propósito de un reciente libro de Villalobos, S. en Boletín del Instituto de Historia Argentina y Americana Dr. Emilio Raviganani, n. ${ }^{\circ}$ 3, 3a serie, Buenos Aires, 1991, págs. 139-145. «Las fronteras y la sociedad indígena en el ámbito pampeano», Anuario del IEHS «Prof. Juan C. Grosso», n. ${ }^{\circ}$ 12, Tandil, UNCPBA, 1997, págs. 22-34. Ratto, S. en «Los Indios y la Revolución en el Río de la Plata. El proceso independentista entre los indígenas soberanos de Pampa y Chaco», en: Bragoni, B. y Mata, S. (comps.) Entre la Colonia y la República, Buenos Aires: Prometeo, 2008, pone énfasis en el uso del indígena en los enfrentamientos hispano-criollos, en un reciente estudio, tomando como objetivo el impacto que produjo la revolución en las poblaciones nativas del Chaco y la Pampa. No obstante, Infesta, M. E. atribuye el cambio en las políticas públicas para la incorporación de tierras a transformaciones económicas a partir de 1816. Al sur del Salado, específicamente en Bahía Blanca, recién adquieren valor hacia 1834. Infesta, M. E. «Avance territorial y oferta de tierras públicas. Buenos Aires. 1810-1850», Anuario del IEHS «Prof. Juan C. Grosso», 12, Tandil, UNCPBA, 1997, págs. 63-68. También Barba, F. E. analiza el tema de la frontera a partir de la ocupación del ganado, en Frontera ganadera y guerra con el indio. La frontera y la ocupación ganadera en Buenos Aires entre los siglos XVIII y XIX, La Plata: Editorial de la UNLP, 1995. 
por el otro una estrategia criolla en un avance que fluctuaba entre compensaciones materiales y tecnológicas para los indígenas hasta llegar a hostilidades cargadas de crueldad en ambas partes ${ }^{107}$.

María Mercedes González Coll, en su tesis doctoral, adopta la tesis de Frederick Jackson Turner, como incubadora del destino manifiesto en la experiencia fundacional norteamericana. La autora retoma las coincidencias con esta tesis en nuestro país en autores como Hebe Clementi, Carlos Mayo y Amalia Latrubesse $^{108}$. Según sostiene, existió un paralelo entre las estrategias y tácticas que aplicaron los castellanos de Canarias y en la América colonial con las llevadas a cabo por Cornelio Saavedra (1810) y Julio Argentino Roca (1879). Tomando las tipologías de Berkhofer, distingue tres tipos de frontera: la internacional, la étnica y la cognitiva. Considera que como proceso temporal la última se inicia en el momento en que los protagonistas se ponen en contacto y concluyen en una unidad política ${ }^{109}$.

A fin de no perder el primer objetivo de esta tesis, intentaremos explicitar en base a los testimonios de quienes dirigieron los diferentes avances fronterizos hasta la definitiva fundación de la fortaleza, sus experiencias, el contacto con otras lenguas, costumbres y grados de comunicación.

\subsection{Las expediciones previas a la fundación de la Fortaleza}

El fracaso de la expedición de Juan de la Piedra, quién partió desde Patagones a la Sierra de la Ventana en 1785, plantea la necesidad de interpretar a la misma, por una parte, como un intento de avance de la frontera por parte de la Corona, del sur hacia el norte, al igual que la de de exploración en la búsqueda de una vía de comunicación terrestre con Buenos Aires. Por otra, como una estrategia de mayor protección al fuerte del Carmen de los avances indígenas al igual que de ganancia de tierras para la agricultura. Esta última, obraba como asignatura pendiente a los pobladores maragatos. Biedma sostuvo que el fracaso de la expedición de de la Piedra, se debió a no contar en ese momento con «influencia moderadora» sobre quien podría haberlo realizado Francisco de Igarzábal ${ }^{110}$. Antes de partir a esta campaña, dejó en el gobierno de Patagones — en forma interina- a Isidro Bermúdez ${ }^{111}$. Luego del

107 Barsky, O. y Djenderedjian, J. Historia del capitalismo agrario y pampeano. La expansión ganadera hasta 1895, Tomo I, Universidad de Belgrano, Buenos Aires: Siglo XXI, 2003, págs. 75-127.

${ }^{108}$ González Coll, M. M. La vida en la frontera sur. Relaciones interétnicas y diversidad cultural, Bahía Blanca: Ediuns, 2000, pág. 110.

${ }^{109}$ González Coll, M. M. «Frontera Sur...¿Qué frontera?», en: González Coll, M. M. (comp.) Viejos y nuevos estudios etnohistóricos, Bahía Blanca: Ediuns, 1999, págs. 27-34.

${ }^{110}$ Ministro de la Reales Cajas en el Río Negro desde 1780-1792. Su mal estado de salud lo había obligado temporariamente a abandonar Río Negro, quedando en su cargo interinamente Francisco Javier de Piedra. Biedma alegará que el fracaso de la expedición no solo fue la pasión con que emprendió de la Piedra la misma sino el fracaso de su carrera pública y la indiferencia de sus contemporáneos. Biedma, J. J. Op.cit., 1905, pág. 240.

111 AHPBA. Lista que comprende los Asientos de los Empleados en el establecimiento de Río Negro. Costa Patagónica, año 1778, anaquel n. ${ }^{\circ}$ 13. «En decreto por el Sup. Intendente General el 5 de febrero de 1787 se le 
enfrentamiento y muerte en manos de los indígenas, de la Piedra fue reemplazado en su puesto por el alférez Lázaro Gómez y Rospillosi ${ }^{112}$. En la abortada expedición participó entre otros León Ortiz de Rozas, padre de Juan Manuel, quien quedará junto a otros dragones, como prisioneros de los indígenas. Esto significó el fin de los intentos por llegar de sur a norte a la Sierra de la Ventana y a Bahía Blanca, en el siglo XVIII.

Al enumerar a los empleados de la corona arriba citados, hemos pretendido demostrar cómo sus títulos, status social, eruditos con o sin diploma universitario, les otorgaba legitimidad y la confianza de las autoridades en la dirección u organización de determinadas empresas.

En 1804, Sebastián Undiano y Gastelu, Capitán del Regimiento de voluntarios de milicias de Mendoza, presentará un vasto proyecto ante la autoridad virreinal para «la conquista pacífica de diez y siete mil leguas cuadradas de tierra» ${ }^{113}$. En él elaboró un trapecio geográfico, cuyos dos ángulos agudos caían en la boca uno del río de la Plata y de Mendoza y «á los obtusos corresponde la confluencia del Río Diamante con el Negro, y la desembocadura de éste en el Atlántico, en Patagones». El proyecto de Undiano, daba valor a la recuperación de la costa atlántica desde el río de la Plata hasta la desembocadura del río Negro. Buscaba destinar fondos para poblar estos territorios y generar una vía de comunicación terrestre y desarrollo económico con las sierras de la Ventana, la del Volcán y establecer cabecera del río Colorado. Undiano propone que «en la confluencia del Diamante con el Negro sería bien poner, la mayor fuerza ya por ser este punto más remoto de nuestras fronteras actuales...» ${ }^{114}$, reconociendo la indefensión y la necesidad de auxilio en la que se encontraba la ciudad del Carmen. La concreción de su plan, auguraba un futuro mejor para las poblaciones, fortaleciendo en estos fuertes el mercado de cuero, sebo y carne salada para Europa, y de mulas para Perú y Chile. Este militar español sin duda demuestra rigor científico en cuanto a sus conocimientos geográficos y sociológicos, en la descripción de los pobladores de la frontera. Establece dos tipologías de hombres en la campaña: soldados llamados blandengues y «paisanos que vive bajo el cañón de los fuertes». Planifica una distribución de tierras, viviendas y sueldos como una forma de seguridad en el asentamiento, que evitaría el nomadismo de estos pobladores, en virtud de reconocer a ellos como «verdaderos agrónomos». Estas últimas palabras del documento revelan como los instrumentos de posesión del conocimiento práctico sobre la explotación de la tierra, podían generar canales de avances científicos y a su vez, facilitarían el alcance a la propiedad privada.

mandan a abonar cien pesos mensuales... sirvió en empleo desde 1785 que falleció don Juan de la Piedra». Dos años después habría recibido el pago de sus servicios a la Corona.

${ }^{112}$ Casado con Francisca Obligado, pertenecía a una distinguida familia del Buenos Aires colonial. Será Pastor Obligado quien haga conocer el Diario de su abuelo sobre esta expedición, que consta de 34 páginas. Claro indicio de conocimiento y saberes de la lengua escrita, Biedma, J. J. Op.cit., 1905, pág. 247.

${ }^{113}$ Undiano Gastellu, S. «Proyecto de traslación de las fronteras de Buenos Aires», en: Angelis Pedro de Colección de Obras y Documentos relativos a la Historia Antigua y Moderna de las Provincias del Río de la Plata, ${ }^{\mathrm{a}}$ edición, Tomo I, Buenos Aires: Lajouane, 1910; págs. 429-433.

${ }^{114}$ Undiano Gastellu Ídem, pág. 431. 
La Junta Superior Gubernativa por oficio del 15 de junio de 1810, continuará con su proyecto de avance de la frontera. Cornelio Saavedra y Mariano Moreno encomendarán a Don Pedro Andrés García a averiguar el estado de los fuertes de frontera y proponer medios de mejora ${ }^{115}$. El inicio de su memoria describe en la utilización de un lenguaje pretencioso, el homenaje a la autoridad de la Junta y su identidad por lo que él llama «la patria» y el «encargo más honroso que ha podido hacerse jamás a un ciudadano». En una primera lectura, estas frases son indicativas de la celebración e identidad con los principios de Mayo, que lo excluye de la antinomia de «enemigo» en que los españoles se habían situado a partir de 1810, como puede observarse en la literatura criolla de la época. ${ }^{116}$. Como contrapartida, situándonos en el nivel del campo intelectual, el análisis discursivo de García, sintetiza una admiración hacia el proyecto juntista por parte de un exfuncionario español, que ahora se considera «ciudadano» de esta nueva patria, antes colonia de su país de origen. Existe en sus palabras una variación de su antigua fidelidad al rey como base de del orden social, por el de ciudadano que introduce la Revolución de Mayo a los hombres que alistó en sus ejércitos ${ }^{117}$. Su crítica se centraliza en la codicia e ignorancia de los monopolistas de Buenos Aires, que habrían llevado a la misma a una economía de consumo, de «miserable» exportación y contrabando. La escasez de espacios de socialización durante la Colonia, había conducido — según su criterio - a que los habitantes se reunieran solo por cuestiones de religión o defensa, «desconociendo las necesidades del hombre civilizado, se resintiesen de la indolencia é ignorancia de sus bárbaros vecinos» ${ }^{118}$.

El Diario de este español debe ser comprendido como un invalorable documento, que nos permite observar en su descripción que presentan las estancias y chacras en la campaña bonaerense como también sobre las condiciones de vida y la situación de los labradores y sus familias, en la campaña bonaerense. Conforme a un pensamiento fisiócrata, García, pretendía la «transformación de los hombres de la campaña en ciudadanos virtuosos, aplicados e industriosos» y presentaba un plan de gobierno en la mensura, división, repartición y formación de pequeñas poblaciones que dieran seguridad a la frontera y además promovieran la agricultura. Delinear o proyectar un pueblo significaba establecer una plaza central, un lugar para la iglesia, el hospital y la cárcel. En este punto, y en razón de lo analizado previamente sobre «Patagones como espacio de aislamiento», el autor de esta memoria reflexiona acerca

115 Oriundo de Santander, España, se desempeñó como alférez del Real Cuerpo de Ingenieros del virrey Ceballos. Participó en las invasiones inglesas de 1806, y luego desempeñó cargos civiles en la Real Audiencia y Escribano de la Real Renta. Con los sucesos del 1 de enero de 1809, estuvo alineado a la causa de los criollos, junto con Saavedra. Datos obtenidos en Udaondo, E. Diccionario Biográfico Argentino, Buenos Aires: Coni, 1938, págs. 440-441.

116 Pérez, M. A. «La construcción del enemigo: el antiespañolismo en la literatura revolucionaria porteña (18101820)», en: Barba, F. E (dir.). Anuario del Instituto de Historia Argentina, n. ${ }^{\circ}$ 10, La Plata, Facultad de Humanidades y Ciencias de la Educación, 2010, págs. 37-55.

117 Cansanello, O. C. «Ciudadano/vecino», en: Goldman, N. (dir.). Lenguaje y revolución, Buenos Aires: Prometeo, 2008, pág. 23.

${ }^{118}$ García, P. A. «Diario de un viaje a las Salinas Grandes en los campos del Sud de Buenos Aires», en: Angelis, P. de. Colección de Obras y Documentos relativos a la Historia Antigua y Moderna de las Provincias del Río de la Plata, 2a edición, Tomo III, Buenos Aires: Lajouane, 1910; pág. II. 
de los efectos que el aislamiento produce en el hombre, que se hace «feroz y salvaje», haciéndolo rehuir del trabajo. Para Gelman es típico de esta etapa los intentos de criminalización de la población rural pobre acusada de vagancia y excesiva independencia, que atentaban contra el modelo de orden y control de la propiedad propuesto por las nuevas autoridades ${ }^{119}$. No obstante, en el caso específico del discurso de García está presente la existencia de lo que Pilar González Bernaldo llama «nación identitaria» que precede a la construcción del estado nacional, en las invocaciones que realiza para formar una patria y en las condiciones necesarias que tendrían los hombres para ser ciudadano de ella. Esto obligaba a las comunidades a imaginar una sociedad sin monarca y por ende con un sujeto activo en esta relación ${ }^{120}$. Pero el plan de García fortalece la formación de sociedades patrióticas, «que llevan al seno de los campos las luces y los socorros á los desvalidos labradores: que los instruyen no por medio de vanas teorías, sino con ejemplos prácticos...». Este español realiza formulaciones educativas fisiócratas que responderían al conocimiento de pensadores como el Padre Feijóo, Campomanes y Jovellanos. Entre ellas están las que acentuaban la enseñanza en el uso de instrumentos de labranza, de los secretos de la agricultura que les permita conocer plantas hasta ahora desconocidas. Propiciando una educación civil y cristiana, que mejoren las poblaciones y establezcan industrias. La educación de «los sabios y literatos patriotas» es la que conduce a la felicidad de los hombres.

El plan propuesto parte, en primer lugar, de un punto central en la laguna de las Salinas y apoyando su izquierda en las nacientes del río Negro de Patagones. La expedición que se extendió desde el 21 de octubre hasta el 22 de diciembre de 1810, llega en el mes de noviembre a la sierra de la Ventana. Mantiene su primer contacto con los indígenas de esta región el día 7, con el chasqui cacique Quilapí quien pide permiso para hablar, aunque según su testimonio se presentara con su gente armada formados en batalla ${ }^{121}$. Concluida esta expedición hacia la zona del sudoeste bonaerense, tenemos un amplio espacio de abandono por parte de las autoridades criollas en la continuidad de estos proyectos, hasta mediados de la década del $20^{122}$. Así como la obra del padre Thomas Falkner impulsó el interés estratégico de la Corona por la Patagonia, la traducción de una carta que aparece publicada en Londres, en la que se describía al territorio bonaerense hasta la desembocadura del río Negro, enciende la alerta

${ }^{119}$ Gelman, J. «Derechos de propiedad, crecimiento económico y desigualdad en la región pampeana, siglos XVIII y XIX», Historia Agraria, n. ${ }^{\circ}$ 37, Murcia, SEHA, diciembre, 2005, págs. 467-488.

${ }^{120}$ González Bernaldo, P. «La identidad nacional en el Río de la Plata post-colonial. Continuidades y rupturas con el Antiguo Régimen», Anuario del IEHS «Prof. Juan C. Grosso»,.n. ${ }^{\circ}$ 12, Tandil, UNCPBA, 1997, págs. 109122.

${ }^{121}$ García, P. A. Op.cit. págs. 231-232.

${ }^{122}$ Carta del litoral bonaerense comprendido entre los ríos Colorado y Negro levantada por el polito don José de la Peña. Publicaciones del Instituto de Investigaciones Geográficas de la provincia de Buenos Aires. Facultad de Filosofía y Letras. En la lámina XXII, y en su descripción, se hace alusión al plano topográfico de las Salinas, aunque se pone en duda que la elaboración fuera hecha por el mismo García a quien se lo califica como «profesional de señalada actuación, pero escasa competencia». José de la Peña tendrá posteriormente un rol protagónico como Alférez de Navío de la Real Armada, a cargo de la goleta «Araucana» en 1809.AGN, Sala IX, División colonia 28-5-6-1776-1810. 
de las autoridades bonaerenses en dar continuidad a la política fronteriza ${ }^{123}$. En ella aparece marcado el camino al fuerte de la Independencia (1823), estando indicado el camino que se dirigía a Patagones pasando por la bahía Blanca. La creación en 1825 de la Comisión Topográfica, destinada a la formación de una mapoteca oficial cuyos empleados estarían especializados en astronomía, geodesia, ingeniería y arquitectura, configura el quiebre estructural de un avance en la frontera, donde estuvieran determinados de antemano no solo el establecimiento de fuertes y población, sino el estudio del espacio, la fauna y flora que lo ocupaba. Esta nueva forma de ver el avance de frontera, implicaba por un lado, el uso de instrumentos de conocimiento científicos que facilitarían una mejor visión de la realidad espacial que ofrece el territorio bonaerense. Por el otro, el análisis en la construcción de producciones simbólicas - como el idioma, las ritualidades, las prácticas religiosas - que favorecieron posteriormente la comunicación e integridad de dos grupos etarios.

\subsection{Los indios amigos}

En cuanto al contacto con los indígenas, en todo el proceso de avance fronterizo, existieron aborígenes que facilitaron la comunicación entre ambos grupos cuya ruptura partía del desconocimiento de la lengua o dialectos de las diferentes culturas. La lengua constituye objeto de estudio en determinados momentos según los objetivos de esta tesis, por ser el primer escalón de comunicación verbal. La producción discursiva se producirá cuando exista una integración formal de estos «indios amigos»a la educación, que recién pudo ser concretada y constatada documentalmente en $1862^{124}$.

La calificación de indios amigos que reciben por los actores encargados del avance fronterizo, corresponde a una categorización de indígenas situados en las zonas cercanas a los fuertes, en los espacios más lejanos de la frontera y que actuaban como intermediarios económicos en las transacciones comerciales. Marta Bechis sostiene que bajo esta calificación estaban los indios reducidos o sometidos ${ }^{125}$. Esta situación se producía en un proceso que la autora denomina «aculturación antagónica» que consistía en incorporar elementos culturales materiales y no materiales del otro con el fin de hacer más eficaz su propia resistencia. Para Osvaldo Barsky bajo esta calificación estaban aquellos indígenas que durante el gobierno de Rosas mantienen una compleja red de intercambio de bienes y de información muy jerarquizada. Es el momento — a nuestro entender — de la construcción de lazos de relación personal que se habían visto trastocados por una política operaciones violenta y agresiva hacia ellos

${ }^{123}$ Martínez Sierra, R. El mapa de las pampas, Tomo II, Buenos Aires, 1975. El Archivo de Geodesia de la Provincia de Buenos Aires conserva esta «Carta de la Provincia de Buenos Aires» de 1824.

${ }^{124}$ Archivo Municipal de la Municipalidad de Bahía Blanca, 17 de mayo de 1862 (A.H.M.B.B). Elena Rebok hará breve referencia a la educación indígena en la frontera en una etapa posterior en «Los hacendados y la frontera (1866-1874)», Investigaciones y ensayos, Buenos Aires, Academia Nacional de la Historia, n. ${ }^{\circ}$ 27, págs. 389440.

${ }^{125}$ Bechis, M. «Fuerzas indígenas en la política criolla del siglo XIX», en: Goldman N. y Salvatore R. (comps.) Caudillismos rioplatenses. Nuevas miradas a un viejo problema, Buenos Aires: Eudeba, 1997, págs. $293-317$. 
entre 1821 a 1827 . El gobernador Manuel Dorrego en su mensaje de fecha 4 de octubre de 1827 en el que diseña la nueva estrategia de avance fronterizo, «propone una conducta equitativa y amistosa» que evitara enfrentamientos con «los salvages», a quienes reconoce la capacidad de movilidad en el espacio a ocupar, atento «a los conocimientos prácticos del terreno sobre que se ha de determinar la línea de frontera ${ }^{126}$. Con posterioridad, Rosas advierte como Comandante de Milicias de Frontera al Coronel Estomba sobre los riesgos que tendrán en la instalación de los fuertes de Laguna Blanca y Bahía Blanca y la peligrosidad de los «indios enemigos», confiando en la experiencia de quienes han sido comisionados para la expedición ${ }^{127}$.

Esta confianza que dice tener sobre el fundador está, como contrapartida en relación a los saberes adquiridos en las prácticas militares en diferentes espacios geográficos, que lo hacían capaz de sobrellevar la fuerte incertidumbre que provocaría un posible ataque del enemigo. En este caso, hacía referencia al indígena sin relación de subordinación o de acuerdos previos con comandantes o jefes de milicias. Podremos individualizar en cada uno de los hombres que acompañan a Estomba, el dominio de una ciencia, que trasciende en su discurso y en su lingüística. Esto nos permite inferir la existencia de un discurso netamente castrense, donde la cuestión de la sintaxis está ligada a su expresión escrita.

\subsection{La Fortaleza Protectora Argentina según el discurso de sus fundadores}

Siguiendo los postulados metodológicos de Hofstede, sobre la existencia de diferentes dimensiones que diferencian a las culturas, y a los que adscribimos cuando hicimos el análisis fundacional de Patagones, seleccionamos los componentes: a) la relación de los fundadores con las autoridades del poder central y las variables que la dificultaban como la comunicación terrestre y marítima, escasez de víveres y de espacios de sociabilidad y la incertidumbre sobre posibles ataques indígenas. b) La incertidumbre fue un factor que generaba estados de cólera, violencia o tristeza que amenazaban su armonía emocional como había sucedido en la Ciudad del Carmen ${ }^{128}$. Existían, además, indicadores de macro-culturales estructurales, como la educación o instrucción formal recibida en su pasado por estos individuos y políticoeconómicas que los impulsaba al acceso a la tierra, a través de estos viajes. Estos indicadores se tratarán de buscar en el sentido oculto que atravesaba — como sostiene Goldman — la superficie del lenguaje, puesta de manifiesto en el documento histórico, en su lengua, su estilo y escritura ${ }^{129}$.

${ }^{126}$ Documento para la Historia de Bahía Blanca, Ministerio de Educación de la Nación, Bahía Blanca, Instituto Tecnológico del Sur, 1951.Tomo 1, págs. 12-13.

${ }^{127}$ AGN, Sala X. 14-10-6

${ }^{128}$ Crespi Valls transcribe una página del periódico unitario El Pampero del 21 de marzo de 1829 sobre el estado de salud «pérdida de la razón» en la que ha llegado el coronel Estomba a Buenos Aires. Este mismo autor, hace referencia a «una razón que se nublaba» siendo todavía Comandante en Bahía Blanca. Este último dato no ha podido ser cotejado por ninguna fuente documental certera. Op. cit., págs. 122-126. Situación similar habían sufrido los expedicionarios de la Piedra y Antonio de Viedma, en Biedma J. J. Crónica, op.cit., 1905.

${ }^{129}$ Goldman, N. El discurso como objeto de la historia, 1a ed., Buenos Aires: Hachette, 1989. 
Tal como lo hemos sostenido, la fundación de Bahía Blanca, fue impulsada primero el conflicto con el Imperio Lusitano, que había demostrado su intervención directa en la pretensión de apropiación de la boca del río Negro abortado en 1827 por la población maragata ${ }^{130}$; segundo la necesidad del gobierno rivadaviano de poblar la campaña formando centros urbanos protegidos más allá de los fuertes de Dolores (1817) y Tandil (1823), según los acuerdos que se sostenían con los indígenas ${ }^{131}$. Otro aspecto que considero imprescindible destacar es que los actores que llevarían a cabo el emprendimiento constituían un grupo destacado o llamado «distinguidos» de la oficialidad. Esta categorización se las otorgaba su participación en las expediciones libertadoras de Chile y Perú, bajo las órdenes José de San Martín, de Manuel Belgrano o del general Juan Gregorio de Las Heras, entre 1813-1824. El carácter de «distinguidos», como son calificados documentalmente, puede ser atribuido al poder simbólico y heroico que habían adquirido estos oficiales formados en las prácticas militares junto a destacados oficiales. Las interacciones simbólicas que se instauran en el campo militar se debían al grado de formación donde se debe tener en cuenta el aporte de técnicas y conocimientos militares recibidos en sus prácticas cotidianas como en academias ${ }^{132}$, estas variaban desde las de ingeniería, astronomía, matemática y ciencias naturales. La burguesía porteña (comerciantes y miembros de la vieja burocracia colonial) contaba entre sus miembros antiguos militares que habían pertenecido a cuadros realistas, y ahora, en razón de la participación de las guerras civiles y de la independencia, eran sus hijos quienes sostenían el legado. Desde el punto de vista social, destacamos en especial, estos oficiales de cuadros superiores, como Andrés Morel, Narciso del Valle, Juan Elías, Martiniano Rodríguez podemos afirmar que muchos de ellos provenían de viejas familias de comerciantes porteños, montevideanos y del Alto Perú.

Los hechos que precedieron a la fundación de la Fortaleza Protectora Argentina, tal como lo manifestamos, fueron la expedición de José Valentín García en 1823, enviado para establecer un lugar o puerto estratégico sobre el Atlántico, y cercano a Patagones. Este proyecto será avalado por el Registro Estadístico de la provincia de Buenos Aires el 16 de febrero de 1824, siendo gobernador Martín Rodríguez. El ataque lusitano al fuerte del Carmen, acelera el proyecto que Bernardino Rivadavia había presentado en la legislatura bonaerense en 1827. Tras su renuncia como presidente de la Nación reanuda

${ }^{130}$ Entre el 7 de febrero y el 7 de marzo de 1827, se produce el ataque de una flota compuesta de 5 navíos y numerosos efectivos pertenecientes al Imperio de Brasil cuyo objetivo era inutilizar el puerto de Patagones. La agresión brasilera había tenido su inicio en 1825 con la llegada del corsario «Río de la Plata», AGN, Sala X- 445-34. Caillet Bois, T. «Los corsarios durante la guerra con el Brasil», Boletín del Instituto de Investigaciones Históricas, Tomo X IX, Facultad de Filosofía y Letras, Buenos Aires, 1935, pág. 11.

${ }^{131}$ Banzato, G. y Lanteri, S. Op.cit, pág. 439.

132 José de San Martín, en oficio al coronel mayor Juan Álvarez de Arenales, donde destaca el «primer ensayo de los valientes libertadores» haciendo referencia a los hombres que estaban bajo sus órdenes. Al igual el reconocimiento como miembros de un «ejército victorioso» y hasta la conversión por parte de los oficiales mayores en figuras propias de la heroicidad griega: «cada soldado muerto es para estas gentes un Hércules». «Memoria Histórica sobre las operaciones y movimientos de la división libertadores a las ordenas del general Don Juan Antonio Álvarez de Arenales», Biblioteca de Mayo, Guerra de la Independencia, Buenos Aires, Tomo XVII, Parte 1, Senado de la Nación, 1963, págs.15168-15275. 
el mismo el gobernador general Manuel Dorrego (16 de agosto de 1827), quien decide extender la frontera sur. En el mensaje de este gobernador del mes de octubre, precisa, entre los fundamentos del proyecto de ley que envía a la legislatura, destacamos los siguientes puntos: la conveniencia de establecer una nueva línea de frontera que desde las puntas del Salado correría hasta terminar en la bahía Blanca, cumplir con los deseos de «los muchos y respetables hacendados», el fundar un punto de unión con la ciudad del Carmen y facilitar el aumento de población, el acrecentamiento de capitales y el desarrollo de su puerto. Cabe decir, que existieron factores político-estratégico-defensivos, económicos y comunicacionales. El análisis de su léxico permite establecer la existencia de una articulación discursiva que lo vinculan con los espacios del poder económico bonaerense: los hacendados.

Dentro de las Instrucciones dadas al coronel Estomba en marzo de 1828, Balcarce propugna un trato generoso, comedido y humano con los indios «salvages», atraerlos a la amistad a través de obsequios. Existía una dualidad discursiva que prevenía - a posteriori- la mala fe y alevosía, con que a veces estos solían actuar, los pueblos originarios. Estos valores propios de los cuadros militares superiores, explícita o implícitamente caracterizan un grupo social: ellos en sus escritos se refieren a lo que eran deseable y a lo que podía o debía hacerse.

Las prácticas militares de estos actores en esta zona de frontera, estarían encuadradas en la definición propuesta por Ricardo Salvatore sobre la existencia de una conexión en las formas de disciplinamiento entre ejército, prisión, hospital y también la escuela. La reproducción de los valores en este caso del ejército, sobre la disciplina del cuerpo y la mente ${ }^{133}$. Estas formas de control se extendieron particularmente a la población campesina y primeros vecinos que se establecen y posibilitaron la continuidad del avance de frontera ${ }^{134}$. La escuela fue posteriormente moldeada en este proceso de instituciones disciplinarias, materializados por prácticas y símbolos de poder.

\subsection{El puerto: su creación y la educación de los artilleros}

Woodbine Parish fue uno de los viajeros que fortalece como causas de la fundación, la necesidad de hacer un reconocimiento exacto de la costa, que permitiera establecer un puerto como punto intermedio que favorecería el comercio marítimo, que actuara como defensa de la costa ante la guerra con el Brasil. La región del sudoeste se había visto convulsionada por este conflicto externo, según lo demostraran los acontecimientos que rodearon a la gesta de los pobladores de la ciudad del Carmen. Ante los desaciertos de Rondeau el gobierno, creyó necesario hacer un reconocimiento exacto de la costa, estableciendo Bahía Blanca en un punto intermedio que combinase el puerto para el comercio marítimo como una buena posición defendible. Para este inglés en la referida línea de frontera de 1828, Bahía Blanca, no

\footnotetext{
${ }^{133}$ Salvatore, R. D. «Reclutamiento militar, disciplinamiento y proletarización en la era de Rosas», en: Boletín del Instituto de Historia Argentina y Americana «Dr. E. Ravignani», Tercera Serie, n. ${ }^{\circ} 5$, Buenos Aires, $1^{\circ}$ semestre de 1992; págs. 25-47.

${ }^{134}$ Garavaglia, J. C. Construir el estado. Inventar la nación, Buenos Aires: Prometeo, 2007, pág. 273.
} 
solo ofrecía un buen puerto sino una comunicación directa entre la provincia de Buenos Aires y la de Concepción de Chile, sobre las costas del Pacífico ${ }^{135}$.

No obstante hasta ese momento se había considerado de escasa atracción económica que presentaba la «bahía Blanca» y su zona circundante. El puerto era fondeado solo por barcos balleneros aspecto que ha sido demostrado en los testimonios de quienes encabezaban o participaban de expediciones terrestres previas. Aquellas que llegaban hasta las sierras de la Ventana, consideraban esta zona como con buenos pastizales y agua suficiente. Félix Weinberg dirá que en esta primera etapa, de fundación y consolidación «Bahía Blanca es un simple enclave militar en la frontera con el indio, y su existencia estaba signada por la pobreza y el peligro» ${ }^{136}$. Los primeros aprestos para establecer el puerto surgen el 14 de enero de 1828, cuando el coronel Estomba «comisionado pa.el establecimien.to de la bahía Blanca pide se le den cinco marineros hijos del país que se hallan al servic.o de la Esquadra cuyos nombres ofrece dar los que le son necesarios p.a el servicio de la ballenera y canoa que han de quedar en el Puerto de bahía Blanca» ${ }^{137}$. El concepto hijos del país estaba asociado al rasgo distintivo que debía guardar un soldado, fundado en los derechos de ciudadanía de los hispanoamericanos, y que debía contar con su ejército y/o armada. La artillería se caracterizaba por el uso de otro armamento como cañones y armas de fuego portátiles, creado por ley del ejército nacional (1 de febrero de 1826) la maestranza de este cuerpo militar que funcionaría en el establecimiento del parque.

Se caracterizaba por la peculiaridad de formación de sus oficiales. Su organización denota la importancia dada a los maestros mayores, operarios de taller, recibiendo dos jóvenes entre sus hijos la formación de artesanos del cuerpo, estimulando su aprendizaje. El cuerpo de artillería cuya creación puede encontrarse en los primeros años del proceso revolucionario de Mayo, respondía a razones geográficas (extensión de costas) y necesidad de contar con puntos de desembarco.

En el artículo 6 de las Instrucciones que debían regir al coronel Estomba dadas por Juan Ramón Balcarce el 7 de marzo de 1828, especifica claramente que luego de «situar el Fuerte» recibirá las noticias dadas por el capitán de la Zumaca «Luisa» de Diego Harrison que llevaba a Enrique Jones, encargados de determinar el puerto de entrada y una batería. Ambos serían cubiertos por artilleros y tropa de infantería que llevaban. Todo ello se haría dice textual Balcarce «conforme a los conocimientos que le asisten» al coronel Estomba ${ }^{138}$. Este último había puesto de manifiesto desde su designación a cargo de la empresa fundadora, en contar con «un cuerpo de artillería capacitado», petición que es aceptada por Juan Manuel de Rosas en enero de 1828.

${ }^{135}$ Parish, W. Buenos Aires y las provincias del Río de la Plata desde su descubrimiento, Traducción Justo Maeso, Estudio preliminar J. L. Busaniche, Buenos Aires: Hachette, 1958, págs. 274-276.

${ }^{136}$ Weinberg, F. «Contribución al estudio de la evolución social de la ciudad de Bahía Blanca. 1828-1880», en: Cernada de Bulnes, M. (comp.) Bahía Blanca de ayer a hoy, UNS, Bahía Blanca, 1991, págs. 19-28. Desde el punto de vista cronológico ubica esta etapa entre la fundación hasta 1880.

${ }^{137}$ AGN, Sala X- 14-10-6. Notas del 19 de enero firmada por Juan Manuel de Rosas. Carta de José Rondeau de fecha 30 de enero de 1828.

${ }^{138}$ Documentos para la Historia de Bahía Blanca, op.cit., pág. 16. 
El 30 de enero de 1828, José Rondeau hace lugar a la petición que realiza el coronel Estomba de un oficial capacitado y una dotación de artilleros. El petitorio se realizaba nominando a un teniente en particular, atenta las dificultades que podía presentar la instalación de un puerto al no contar con personal idóneo para tareas específicas. Al referirse a «oficial capacitado» Estomba demuestra conocer la existencia de instituciones pedagógicas militares creadas a tal fin: por decreto del 5 de agosto de 1828 , Dorrego había creado la Academia para oficiales de artillería, existiendo en este decreto en su parte dispositiva una formación teórico práctica de sus alumnos. El fusilamiento de Dorrego dejará trunco este proyecto.

El 4 de febrero, el Inspector General del Gobierno establece que

el Teniente D. Juan J. Mentivien (¿) pase desde el primero del que corre agregado al Regimiento $\mathrm{N}^{\mathrm{o}} 7$ de Caballeria cuyo Coron.el pasará el destino que crea conveniente desde esta fecha de baja en la plana mayor a que pertenece ahora... Que respecto de los artilleros se cree salvada la dificultad para afrontarlos en la resolución adoptada habiéndose dispuesto que para la Comandancia de Marina se hagan desembarcar los Artilleros que existen en la Escuadra con que pueda pasar la dotación que solicita el referido jefe ${ }^{139}$.

No es este un dato menor. La formación requerida es un aspecto dentro de los valores culturales que guiaban al fundador, donde se legitima en sus frases y retóricas el prestigio de quienes lo acompañaran. El discurso de Estomba mantiene — por una parte - procesos de habla propios de una formación militar de marcado verticalismo, en cuanto a las respectivas solicitudes de autorización a las autoridades superiores pertinentes. Por otra, la toma de resoluciones propias a su criterio -independientes de autoridades superiores - hace valer ante sus subalternos la autoridad máxima que detenta. Caben aquí las palabras de Salvatore de considerar a las milicias como «escuelas de disciplina», que contenía un conflicto cultural en el plano del reclutamiento forzoso y la resistencia de algunos milicianos.

En diferentes momentos, Estomba sometía sus peticiones a las personas designadas por el superior gobierno por la especificidad de sus conocimientos, como se desprende del documento del 26 de marzo de 1828, cuando Juan Manuel de Rosas le indica que debe comunicarse a partir de ese momento con Felipe Senillosa. Este catalán, formado en la Universidad de Alcalá de Henares, catedrático de la Universidad de Buenos Aires, estaba desde 1828 a cargo del Departamento Topográfico y fue quien dio las orientaciones técnico-científicas necesarias a Estomba sobre el espacio a ocupar ${ }^{140}$. Al igual el arquitecto Antonio Manuel Molina, profesor de arquitectura, quien se encontraba en Ranchos, debió ponerse a las órdenes del fundador de Bahía Blanca, según lo estableció Juan Manuel de Rosas ${ }^{141}$. Estas dos órdenes superiores ilustran, a nuestro entender, la preexistencia de un plan estratégico militar, en el

${ }^{139}$ AGN, Sala X, 14-10-6. No es clara la caligrafía, impidiendo conocer el exacto apellido del marino seleccionado por Estomba.

${ }^{140}$ AGN, 6 de marzo de 1828, Sala X, 14-10-6. Los datos biográficos de Senillosa corresponden a Zinny, Antonio. Estudios biográficos, Buenos Aires: Hachette, 1958.

${ }^{141}$ AHMMBB, Expediente n. ${ }^{\circ}$ 178/1834. 
cual ocupaba una alta valoración no solo el mero avance de tropas, sino el asesoramiento de profesionales con una educación específica para los cuerpos militares.

Según el análisis de la correspondencia, Rosas manifiesta su recurrente preocupación por dotar de marineros «que han de ser empleados en el reconocimiento y trabajo del puerto de bahía Blanca». Al igual que tener previsto de aquella gente de Patagones que tenga previsto trabajar en este nuevo punto.

Estaba convencido de la necesidad del gobierno de proveer de fondos en forma constante y sin interrupción para evitar la diáspora de la población. Atendiendo que el fuerte estaría emplazado en el «desierto»: «por mar y por tierra los obstáculos para la comunicación y el transporte no son desconocidos...» ${ }^{142}$. Este puerto posteriormente denominado «Esperanza», configuraba para el exponente la importancia de contar con un sistema ágil de trasmisión e intercambio no solo económico, sino de individuos o grupos sociales con intereses en poblar la región. A ello dispuso Rosas enviar un buque con útiles para formar una batería «que proteja la costa con noventa tiros por pieza».

Rosas hizo conocer al Inspector General haber recibido información del coronel Estomba que le ha enviado un buque que conduce los útiles para el establecimiento y con destino a formar una batería. Sostiene que como es probable que el fuerte se va a formar en un desierto: «por mar y por tierra los obstáculos para la comunicación y el transporte, no son desconocidos, yen tal estado las exigencias de

los trabajadores, la necesidad de atraer vivanderos y población...» ${ }^{143} \mathrm{Si}$ se examinan las diferentes notas referidas a la instalación de una batería para el puerto puede apreciarse, por una parte la necesidad de coordinar las actividades de un agrupamiento cultural (en este caso militar), que mantiene homogeneidad en su discurso: la premisa es la urgente comunicación de un espacio de aislamiento. Si bien, predominan variables estratégicas, económicas y políticas; subyace en las formas de vínculos explícitos o implícitos — entre los actores - el reconocimiento de la palabra y el poder a quien se ha confiado una tarea. Ello es producto del valor y legitimidad del saber y práctica, producto de una formación teóricopráctica previa de los hombres que conducen, que comprende mayor autonomía intelectual tanto para dirigir, persuadir o en búsqueda de sus propios intereses (económicos, tierras, investigaciones, curiosidad, etc.).

\subsection{Estomba y la educación de los fundadores}

Para abordar el estudio de la educación de los cuadros del ejército y armada que fundaron la ciudad, fue necesario analizar las regularidades discursivas en los enunciados que pertenecen a una lógica en los discursos castrenses — como existen los económicos, los científicos, médicos- y que guardan ciertas relaciones exteriores que los limitan: asuntos u objetos que se pueden hablar y descripciones y

\footnotetext{
${ }^{142}$ AGN, Sala X, 14-10-6

${ }^{143}$ AGN, 14-10-6, 24 de enero de 1828.
} 
enunciados que guardan cierta modalidad ${ }^{144}$. Estas nos permiten determinar aquellos puntos que revelan dominios de conocimientos teóricos o prácticos, o ambos a la vez. Para ello se procedió a un relevamiento de 216 documentos inéditos del Archivo General de la Nación para interpretar los meses previos y posteriores a la fundación durante el año 1828 y del Archivo Histórico Municipal de la Municipalidad de Bahía Blanca; de documentos éditos del Instituto Tecnológico del Sur, documentos del Congreso General Constituyente (1824-27), del Archivo Histórico de la provincia de Buenos Aires y la Colección de Obras y Documentos para la Historia Argentina de Biblioteca Mayo, entre otros. Pretendemos encontrar en las modalidades enunciativas de los actores involucrados en su producción discursiva, contenidos ideológicos que fueron producto de lecturas previas.

Para fundar la Fortaleza y puerto de Bahía Blanca fue designado el coronel Ramón Estomba, jefe del Regimiento $7^{\circ}$ de Caballería con asiento en Tandil, o Fuerte Independencia. Cada regimiento de caballería estaba dirigido por un coronel, que ejercía la jefatura del regimiento y de una de las compañías. Un teniente coronel, segundo jefe. La plana mayor se completaba con un sargento mayor, dos ayudantes y cuatro portaestandartes, un capellán, un cirujano y un trompeta ${ }^{145}$.

Dentro de los riesgos del análisis biográfico del coronel Ramón Estomba, que brevemente buscamos realizar, tenemos en cuenta las prevenciones de Bordieu sobre la posición que estos militaresintelectuales mantienen en la estructura de la legitimidad, en el campo del poder y en el campo intelectual. A él y los cuerpos mayores del ejército que lo acompañen corresponderá la construcción del habitus como sistema de disposición dominante. Este nuevo «intelectual» no solo se caracteriza por su acción externa sino como partícipe activo de la vida práctica. Surge como constructor y organizador a partir del trabajo y la técnica y el dominio de la ciencia. Pretendemos distinguir la autonomía y estatus social que adquieren esta oficialidad en cuanto productores del discurso escrito con las autoridades centrales. Para ello, analizamos las biografías más precisas que dan sobre su persona: Enrique Udaondo y Antonio Crespi Valls, este último basado claramente en la lectura del primero. También cotejamos la información dada por González Coll ${ }^{146}$. No obstante, rescato un manuscrito original de Estomba que

${ }^{144}$ Marc Angenot sostiene que el discurso de una clase dominante —en este caso en los cuadros superiores del ejército- se imponen por el costo de adquisición de skills (habilidad-destrezas), de competencia, en armonía con los modos de vida. Angenot, M. El discurso social. Los límites históricos de lo pensable y lo decible, Traducción de Hilda H. García, Buenos Aires: Siglo XXI, 2010, pág. 36.

145 Nota: Esos datos los expresamos con el único fin de de ubicar en el escalafón correspondiente a quienes integraban estas tropas, sobre los que pondremos nuestro acento para verificar su grado de alfabetización escrita a través del acervo documental con que contamos.

${ }^{146}$ Udaondo, E. Diccionario Biográfico argentino, Buenos Aires: Coni, 1938, págs. 382-383. El coronel Ramón Estomba, hijo de Pedro y de Tadea Mitre. Nació en Montevideo en 1790, donde cursó allí sus primeras letras. El 6 de julio de 1810 entró a servir en el ejército de Buenos Aires en calidad de distinguido. Tomó parte de las expediciones a las órdenes de Balcarce en Suipacha, Cotagaita y Huaqui. Luego sirvió al Ejército de Belgrano en Las Piedras, Tucumán, Salta, Vilcapugio y Ayohuma. Tomado prisionero permaneció siete años en las cárceles de Callao. Fue incorporado al ejército de San Martín con el grado de sargento mayor en 1820. Hizo la segunda campaña a las órdenes del general Juan Antonio de Arenales y luego con el general Domingo Tristán. En 1823 fue nombrado Jefe del Regimiento 11 de Infantería. En 1824, nuevamente es tomado prisionero en el Callao y 
según nuestro criterio permite desdoblar algunos aspectos de su personalidad. En carta que escribe al señor Inspector general donde dice haber recibido la orden del ministro de Guerra «en la que me nombra p.a. pasar a formar el establecimiento de bahía Blanca, de acuerdo con el Sor. Comandante de milicias de la Campaña» y conducir carruajes y familias a ese punto, dice estar «pronto obedecer de mi en servicio de mi Patria, estoy en aptitud de mandar con la última brevedad y mi ida no depende de otra cosa q.e.de los recursos indispensables q.e. es necesario llevar». Estar al servicio de la «patria», implica en este caso, la actitud de entrega y fidelidad a las autoridades bonaerenses constituidas.

El 9 de febrero de 1828 en un breve documento de puño y letra Estomba informa que conduce 25 reclutas del regimiento a su cargo y del sargento mayor Valle y del capitán Peña ${ }^{147}$. Recién el 11 de febrero, José Morán da instrucciones al Coronel Estomba a quien informa que «se impondrá de la marcha los veinte y cinco reclutas para el Fuerte de la Independencia, al mando del may. D. Narciso del Valle y el capitán Peña, como asimismo movimiento de carretas, caballada y ganado» ${ }^{148}$. En marzo de 1828, desde el fuerte Independencia, Del Valle realiza una precisa, pero a su vez emotiva descripción de la situación de quienes participaban en la expedición:

Estoy enteramente sin víveres de ninguna clase p.a. El alimento de caciques aliados y su gente pues de ciento cuarenta yeguas entre chicas y gdes. que me remitió D.Ig.no F. mazza (¿) de orden del Señor comandante General de Fronteras tube que prestar, á petición del señor Cnel. Estomba cincuenta yeguas para que llevase el Cacique Benancio, las que no se si ha podido reemplazar, $\mathrm{y}$ que me es forzozo echar manos de los viveres con que me auxilian los vecinos para el alimento de esta guarnición teniendo a mis cercanías de quatrocientos a quinientos indios amigos y me seria (sic)imposible decirles no tengo q. darles pues en la providencia no ha quedado mas(sic)

conducido a Matucana. En 1825 fue prefecto del ejército de Bolívar, pidiendo su retiro en julio de ese mismo año. Al año siguiente, fue desterrado de Lima por creérselo complicado en un movimiento contra Bolívar. Crespi Valls, A. El Coronel Ramón Estomba, fundador de Bahía Blanca, Municipalidad de Bahía Blanca, 1954. Foja de Servicios militares del coronel Ramón Bernabé Estomba, manuscrito existente en el Archivo Museo Mitre, en González Coll, M. M. Op.cit, Bahía Blanca,1999, págs. 314-315. Cfr. Cútolo, V. O. Nuevo Diccionario Biográfico Argentino, Tomo II, Buenos Aires: Elche, 1969, págs. 712-713.

${ }^{147}$ AGN, Sala X, 14-10-6, Narciso Valle fue un militar nacido en Santa Fe en 1794, donde se educó y luego se enroló en las milicias de Entre Ríos. Participó con Balcarce en el regimiento de Húsares. En 1830 fue promovido a teniente coronel, militó luego en la campaña de Rosas, pero fundamentalmente como jefe de regimiento de coraceros fue un destacado experto organizador e instructor en los fuertes de Bahía Blanca y Tandil. En 1834 fue nombrado edecán de Juan Manuel de Rosas. Con respecto a Peña, se carecen de datos documentales sobre su nombre en el AHMMBB, salvo esta alusión documental. No obstante cabe suponer que fuera este José María Peña, quien habría actuado a las órdenes del coronel Rauch.

${ }^{148}$ AGN, Sala X, 14-10-6, Narciso del Valle nacido en Santa Fe, fue un militar — según Enrique Udaondo- que «recibió alguna educación en Entre Ríos» donde se enroló en las milicias. Perteneció al cuerpo de Húsares al mando de Balcarce. En mayo de 1824 como sargento mayor combatió contra los pampas en la expedición del general Rodríguez. Este autor dice: «Como jefe de regimiento de Coraceros se hizo notar como un experto organizador e instructor y tuvo a su cargo la comandancia de Bahía Blanca y del Tandil», op.cit., pág. 1078. 
que 7 bolsas de porotos y 2 tercios de sal como lo demuestra la providencia firmada p.el señor Mayor Narciso del Valle por orden al efecto del Señor Coronel Estomba ${ }^{149}$.

La escasez de víveres tanto para su gente, como para ofrecer a los indígenas como intercambio, obligaba al jefe de la expedición a peticionar demandas económicas de los sectores más pobres de la campaña. La asistencia de víveres por otros vecinos consolidaba lazos de solidaridad frente a la incertidumbre que podían presentar quienes lo acompañaban ante los cuadros superiores.

Acompaña y antecede a Estomba en esta empresa, Narciso Parchappe, agrimensor francés, también figura como ingeniero militar, nacido en Epernay (Marne, Francia), donde había realizado estudios militares egresando como subteniente de artillería. En 1818 emigra al Río de la Plata, donde fue acusado del «Complot de los franceses». Liberado posteriormente pasó a Corrientes donde conoce y se vincula con otro francés: Alcides D’Orbigny. En 1822 se desempeñó como catedrático de la Universidad de Buenos Aires en la Academia de Matemática y luego en 1828 fue designado presidente del Departamento Topográfico de la provincia y luego contratado para emplazar las fortalezas Cruz de Guerra y Bahía Blanca, siendo acompañado por el teniente coronel Morel ${ }^{150}$.

El «Diario del Ingeniero Parchappe», es un rico testimonio que nos acerca a la historia de las mentalidades de estos científicos europeos, con muchos gestos de incomprensiones a la cultura hispánica y criolla, herencia de tradiciones diferentes. Este francés parte el día 12 de marzo. La descripción del baqueano, a quien distingue como el personaje «más importante de la caravana», explica el asombro del científico sobre la capacidad de este hombre en el arte de orientarse en territorios inhóspitos, en su sagacidad y en su capacidad de cálculo en la dirección a tomar ${ }^{151}$. El campo de concomitancia que pertenece a los enunciados propios de un científico y que pertenece a un discurso diferente del militar, puede observarse en la descripción y observación de fauna, flora, todas las especies vivas desconocidas y el reconocimiento geográfico. Al igual que el estudio que realiza del parlamento indígena ${ }^{152}$, en los registros de las voces y descripción de los actores participantes. Pone acento en el conocimiento del Cacique Venancio sobre los factores geográficos de la zona como de su destreza en el caballo y en la contradicción — que a su entender - presentaban las cautivas volviendo con sus amos «indios», ante una posible libertad con ellos. El 9 de abril se producirá el encuentro entre Parchappe y Estomba a quien «... le hice ver todas las ventajas de la ubicación que elegí, tanto a causa de la hermosa colina donde debía

${ }^{149}$ A.G.N. Sala X. 14-10-6.

${ }^{150}$ Zinny, A. Estudios biográficos, Estudio preliminar de Narciso Binayan, Buenos Aires: Hachette, 1958.

151 «Diario del Ingeniero Narciso Parchappe», Documento para la historia de Bahía Blanca, pág. 25. Parchappe conforma en los conceptos de Gautreau y Garavaglia uno de los actores que participa en los procesos de «construcción del conocimiento» en las prácticas de delimitación territorial que significa la regulación de un disciplina con técnicas, procedimientos que facilitaron la creación del primer mapa catastral de la provincia. Gautreau, P. y Garavaglia, J. C. «Inventando un nuevo saber estatal sobre el territorio: la definición de prácticas, comportamientos y agentes de las instituciones topográficas de Buenos Aires, 1824-64», en: Garavaglia, J. C. y Gautreau, P. Mensuarar la tierra, controlar el territorio. América Latina, siglos XVII-XIX, Rosario: Prohistoria, 2011, págs. 62-96.

${ }^{152}$ Nota: resaltado con negrita en el documento. 
construirse el fuerte, como de la proximidad de un buen puerto» ${ }^{153}$. La aprobación de Estomba permitió a este francés iniciar su función específica en el trazado del fuerte, realizó observaciones meteorológicas y la elaboración de un mapa.

María Cecilia Rossi y Guillermo Banzato, en un estudio reciente sobre las mensuras de las tierras, parten de la conceptualización de Garavaglia — que se basa en Weber y Bordieu - y consideran que la presencia del estado en estas delimitaciones es «un entramado de relaciones de dominación» sobre un territorio. En el mismo participan el capital de la fuerza física y sus instrumentos de coerción (ejército, policía $)^{154}$. Esto pudo constatarse en el antiguo ejido de Bahía Blanca en el período que va desde 1828 a 1834 cuando se realizó una distribución de tierras para los jefes del ejército y miembros de la plana mayor, y algunos soldados, oficiales y vecinos que se establecieran en forma permanente ${ }^{155}$. Desde 1835 las entregas de solares y tierras favorecieron en gran medida a las familias fundadoras según puede cotejarse en cantón de Bahía Blanca ${ }^{156}$.

Se suscribe el acta fundacional acompañando a estos dos hombres con sus firmas el coronel Andrés Morel, sargentos mayores del Valle y Juan Elías, capitán Martiniano Rodríguez y los vecinos Nicolás Peres, Pablo Acosta y Polidoro Coulin ${ }^{157}$. La presencia de estos tres vecinos ratifica el enfoque interpretativo de la construcción del poder institucional en la campaña sostenida por Raúl Fradkin. Según este autor existían tres tipos de estructura del poder institucional en el mundo rural: la militar miliciana,

${ }^{153}$ Ídem, págs. 40-41-42. Algunos autores consideran que el acta de fundación de la ciudad de Bahía Blanca fue realizada en esta fecha. En el AGN se conserva copia y original en el legajo analizado de Sala X, 14-10-6, en el que claramente figura la fecha 11 de abril.

${ }^{154}$ Rossi, M. C. y Banzato, G. «Explorar y medir en tierra de caudillos: Amadeo Jacques en Santiago del Estero», en: Garavaglia, J. C. y Gautreau, P. Op.cit.; págs. 215-257.

${ }^{155}$ Funes Derieul, C. «Los primeros pedidos de solares en el cantón de Bahía Blanca. El primer escribano y el primer agrimensor», Revista Notarial, Separata 828. Este autor sostiene que la primera comisión de solares fue integrada recién en 1834 por Martiniano Rodríguez y el juez de paz Francisco Xavier Casal. No obstante según el plano original de la Fortaleza de 1834, consultado en Biblioteca Rivadavia de Bahía Blanca, indica que han sido otorgados solares a vecinos como Peres (firmante acta fundacional), Araque y E. Videla.

${ }^{156}$ AGN, Sala X, C24. A9. 4- Cantón de Bahía Blanca.

157 Juan Elías, militar era hijo por parte de su madre de una de las familias más destacadas de Charcas, de donde era originario, recibiendo su formación como cadete de Húsares para luego pasar a la frontera a las órdenes de Rauch. Llegó a ser edecán del general Lavalle en Navarro. Martiniano Rodríguez, militar del cuerpo de Dragones participó de la guerra del Paraguay con Manuel Belgrano. Posteriormente fue un activo actor junto a José de Artigas y Francisco Ramírez, en las guerras civiles. Más tarde, a las órdenes del coronel Rauch, durante el gobierno de Rivadavia (1826) participó en el Regimiento de Coraceros con el teniente Morel en una guerra sin concesiones con el indígena. Luego de la partida de Estomba para alinearse a Lavalle en la Revolución de 1 de diciembre de 1828, y de la posterior muerte de Morel, fue nombrado Comandante de Bahía Blanca. Cutolo, V. Nuevo Diccionario Biográfico Argentino, Tomo II, op.cit., pág. 657. Martínez Sarasola, C. Nuestros paisanos los indios, Buenos Aires: Emecé, [s/a], págs. 202-208. 
la eclesiástica y la judicial. No obstante había un ejercicio de funciones burocráticas de vecinos integrados a las milicias ${ }^{158}$.

La categoría de «vecino» no solo vinculaba a la persona con un determinado domicilio, sino que a partir de la ley electoral o de sufragio universal ideada por Rivadavia y concretada durante gobierno de Martín Rodríguez, legitimó a los «vecinos propietarios» el acceso a las prácticas electorales. Para Marcela Ternavasio, el nuevo régimen representativo no solo reestructura el espacio político territorial, sino que renueva definitivamente las nuevas prácticas políticas de los actores al establecer el sufragio activo universal y directo ${ }^{159}$. La elección de «elegidos»y «electores» generó una calificación social que fue más allá de las restricciones de edad o las económicas. Las nuevas listas de candidatos y electores muestran la supremacía de una clase sobre el conjunto de la sociedad. El plano en el que se ejercita el poder, en términos gramscianos, es el de la hegemonía de quienes tienen el dominio del saber: militares, en nuestro caso, surgidos en las guerras de la independencia, doctores, clérigos, comandantes, jueces de $\operatorname{paz}^{160}$.

Con posterioridad a la fundación estos vecinos constituyeron redes familiares conformando simultáneamente una pequeña burguesía que ocuparía indistintamente cargos como en la justicia de paz, en la comandancia y en la educación. Tomamos como ejemplo el caso de Pablo Acosta (1838) quien se desempeñó como juez de paz siendo comandante Martiniano Rodríguez. Igualmente serán los principales beneficiados en las primeras concesiones de tierras, en razón de su cercanía con el poder y su capacidad de petición. Este vecino escribe:

\begin{abstract}
Pablo Acosta, becino y del comercio de éste Establecimiento con el debido acatamiento ante por justificación del Señor Comandante se presenta y dice...suplica se digne para que en todo tiempo poner a cubierto sus intereses acceder a la gracia que en justicia le espera recibir sirviéndose autorizarle con el título de propiedad para que de este modo poder poner en obra sus correspondientes fosos y edificios ${ }^{161}$.
\end{abstract}

En cada mensura de estos nuevos terrenos puede observarse por una parte cómo los pedidos favorecieron a los primeros vecinos, pero por otra, el conocimiento que estos demuestran de sus derechos, el marco geográfico y condiciones políticas. La formación de agentes técnicos para el Departamento Topográfico tenía una vinculación no solo entre quienes mensuraban las tierras, sino con

${ }^{158}$ Fradkin, R. (comp.) El poder y la vara. Estudios sobre la justicia y la construcción del Estado en el Buenos Aires Rural, Buenos Aires: Prometeo, 2007, pág. 27.

${ }^{159}$ Ternavasio, M. «Nuevo régimen representativo y expansión de la frontera política. Las elecciones en el estado de Buenos Aires: 1820-1840», en: Annino A. (coord.). Historia de las elecciones en Iberoamérica, siglo XIX. De la formación del espacio político nacional, México: Fondo de Cultura Económica, 1995, págs. 66-105.

${ }^{160}$ Gramsci, A. Antología, Selección, traducción y notas de Manuel Sacristán, Buenos Aires: Siglo XXI, 2004, págs. 272-273.

${ }^{161}$ AHMMBB, Expediente n. ${ }^{\circ}$ 162: «Pablo Acosta». Este documento también ha sido reproducido en una separata de la Revista Notarial n. ${ }^{\circ} 828$, cuyo autor es Funes Derieul, C. Los primeros pedidos de solares en el Cantón de Bahía Blanca. El primer escribano y el primer agrimensor, Colegio de Escribanos, provincia de Buenos Aires. 
los actores que participaban en los emprendimientos expedicionarios, siendo receptores naturales de las primeras parcelas.

\subsection{La comisaría como antecedente de la justicia de paz en la Fortaleza Protectora Argentina}

Nuestras instituciones judiciales tienen una base eminentemente hispana. Con la ruptura de los vínculos políticos con la península se produjo una paulatina adecuación de organismos como la Audiencia o el Cabildo a la nueva realidad bonaerense ${ }^{162}$. Durante la gobernación de Martín Rodríguez, Alejo Castex y Tomás Antonio Valle presentan un proyecto sobre la nueva organización judicial de la provincia (1821). En el mensaje del gobernador al Congreso del 1 de mayo de 1822 éste asegura la notable mejoría de la justicia «pr.el zelo de los encargados q.e correspondían a sus deberes...que la policia llenaba sus objetos en quanto permitia su institución reciente» ${ }^{163}$.

Estas instituciones que se extenderían hacia todo el interior de la campaña, se encontraban adecuadas al marco de la modernización del sistema jurídico rioplatense y de un nuevo Estado ${ }^{164}$. Abelardo Levaggi realiza un importante estudio sobre las comisarías de campaña según la ley del 24 de diciembre de 1821. Este estudio quedó limitado a las comisarías que se establecieron hasta 1828. No obstante la cuestión que plantea el autor es primordial para los fines de este estudio: ¿Qué esfera de facultades — se pregunta - quedaba para los comisarios? La primera era que hasta tanto no se designaran las autoridades correspondientes a los juzgados de paz, tendrían las atribuciones que antes les cabía a los alcaldes de la hermandad. Pero, en segundo lugar, apunta que la delimitación de las funciones de estos comisarios estaba supeditada «a la actividad y buen juicio de éste» ${ }^{165}$.

Desde un primer momento Juan Manuel de Rosas manifiesta su preocupación por proveer a Estomba de los fondos suficientes para el funcionamiento de una Comisaría en el fuerte. En nota dirigida a la superioridad el 18 de enero, Rondeau considera necesario proveer la suma de 76.100 pesos para su instalación ${ }^{166}$. El tema de la falta del envío de fondos para la comisaría es recurrente en diferentes notas que elevan Rosas, Rondeau y Estomba. Según documento anexo, la suma solicitada tenía como finalidad el pago de salarios para «trabajadores, jornaleros, etc., regulada de la siguiente manera: doscientos trabajadores de la tropa, 150 voluntarios, 100 indios, un ornero, cortador de adove, albañil, carpintero,

${ }^{162}$ Cfr. Tau Anzóategui, V. «La noción de la ley en América Hispana durante los siglos XVI al XVIII», en: La ley en América Hispana. Del descubrimiento a la emancipación, Buenos Aires, ANH, 1992.

${ }^{163}$ Archivo Histórico de la provincia de Buenos Aires, Acuerdos del Honorable Junta de Representantes 1822, La Plata, 1981, pág. 13.

${ }^{164}$ Díaz, B. Juzgados de paz de Campaña de la provincia de Buenos Aires (1821-54), Universidad Nacional de la Plata, 1959.

${ }^{165}$ Levaggi, A. «La seguridad en la campaña bonaerense entre los años 1821 y 1828», Investigaciones y Ensayos, n. ${ }^{\circ}$ 20, Academia Nacional de la Historia, Buenos Aires, 1977, págs. 377-410.

${ }^{166}$ AGN, Sala X, 14-10-6. 
herrero, proveedor, escribiente» ${ }^{167}$. En este mismo documento está previsto el traslado de doscientos prisioneros, entre los que se encuentran pescadores, sangradores y artesanos, «que llevan aplicado según su oficio y capacidad».

Para Fradkin existía una diferencia sustancial entre jueces de paz y comisarios. Para este autor los primeros debían ser parte de la comunidad y «eran legos», no recibían remuneración mientras que los segundos podían ser extraños y ser el embrión de una burocracia estatal al ser rentados ${ }^{168}$. El pago de salarios al que hace referencia el documento certifica que quienes participarían en la construcción de la comisaría se convertirían en empleados del gobierno bonaerense. La selección había estado hecha por sus técnicas y capacidades en los oficios o en el caso del escribiente, el saber indispensable de la escritura. Por ello, abordaremos más adelante cómo la elaboración y redacción de sumarios son una fuente de indagación del nivel educativo de sus actores. También se desprende del discurso de Rosas que establecía una distinción entre los prisioneros en oficios, como pescadores y artesanos o por sus saberes, como era el «sangrandor».

A través de la lectura de las Instrucciones para la instalación de la Comisaría enviada por Rosas al Comisionado al Inspector General seleccionamos rasgos fundamentales de prácticas y estrategias de ocupación del territorio en cuanto a los siguientes ítems:

- El cálculo del presupuesto que permita la disminución de mano de obra y la utilización de trabajadores voluntarios y prisioneros.

- El estudio de los cambios climáticos que influirían a su vez, si los trabajos se realizaban antes de la llegada del invierno, en el abaratamiento de costos.

Esta última cuestión, es esencial para comprender el problema de control político y jurídico necesario para la ocupación del territorio del sudoeste.

\subsection{La vecindad y la fundación}

En diferentes momentos de esta parte hemos tratado el tema del «vecino» y la diferencia que existía entre ellos con quienes no gozaban de la libertad: mulatos, indios, etc. Tomando el cantón de 1835 y el de 1836, podemos observar que en hojas separadas aparecen los diferentes «vecinos propietarios», que encabezan con nombre completo una lista. Luego surgen los «dependientes», «muchachos», «peones», «esclavos»y «chinas». Estos últimos con la consiguiente calificación por castas: blancos, pardos, negros, chinas. Las mujeres de los vecinos propietarios aparecen en lista aparte o como «mujeres propietarias» al igual que los «niños». Entiéndase estos últimos como los hijos legítimos o reconocidos del «vecino propietario». Entre los vecinos que aparecen en los cantones señalados se encuentran

\footnotetext{
${ }^{167}$ AGN, Sala X, 14-10-6.
}

${ }^{168}$ Barral, M. E. y Fradkin, R. O. «Los pueblos y la construcción de las estructuras de poder institucional en la campaña bonaerense (1785-1836)», en: Fradkin, R. O. El poder y la vara. op. cit, págs. 25-58. No obstante Gramsci ha distanciado entre lego y docto, aspecto que es de grado y especialización y no de dotes. 
algunos de los que participaron directamente en la empresa fundadora. De ellos solo algunos alcanzan — por su nivel de educación o de saberes adquiridos - lugares de reconocimiento dentro de las estructuras del poder institucional. En base a los documentos trabajados se seleccionaron algunos de ellos:

a) Don Juan Díaz y Ramón Fresno

En documento que lleva fecha 30 de enero de 1828 se incluye la nota del «profesor» Dn Juan Díaz, nombrado al punto de Bahía Blanca, quien había manifestado su deseo de no marchar. A pesar de ello no se hace lugar a su petitorio y se le informa que junto con Don Ramón Fresno han sido destinados a «la bahía Blanca». De la lectura del documento, se desprende que ambos «vecinos»—en contra de su voluntad - se someten al poder de mando del comandante Rosas quien no acepta las peticiones de los mismos ${ }^{169}$. Juan Francisco Díaz con su firma «manifiesta las familias que pertenecen de los individuos del expresado piquete de artillería a mi cargo». En total surge de este documento que son 12 las personas a su cargo, (1 sargento, un cabo y un artillero) entre las que se encuentran 4 mujeres y 8 hijos ${ }^{170}$.

Don Ramón del Fresno es reconocido por sus conocimientos en la medicina, siendo reconocido como «cirujano» en la lista que acredita «el pagamento a la oficialidad, tropa, empleados y familias en el mes de diciembre de 1834. Como punto comparativo podemos tomar algunos de los valores recibidos en sueldos por los miembros de la Plana mayor y este cirujano:

-Capitán Francisco Morel

-Capitán Francisco Iturra

-Alférez Faustino Benítez

-Cirujano D. Ramón del Fresno

-Maestro Armero Francisco Chacón

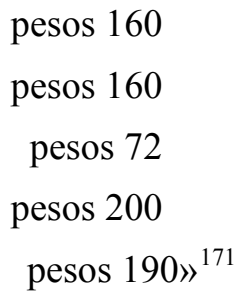

El salario de Fresno es levemente superior al de los oficiales y maestro armero. Esto permitiría inducir una mayor valoración a su profesión de cirujano.

b) Francisco Antonio Palao

El 9 de abril de 1828 José Rondeau eleva la propuesta para que el teniente segundo de la Compañía de Infantería «de nueva creación que manda á la bahía Blanca a favor del Alférez del Regimiento $\mathrm{n} .^{\circ} 7 \mathrm{de}$ Caballería de línea Dn. Francisco Antonio Palao. La insp.n instruida de las aptitudes del propuesto para el empleo, á qe. Es consulta lo considera acreedor, a qe.se lo confiera a dho.empleo».

Esta petición será aprobada con fecha 11 de abril. Francisco Palau conformará un grupo familiar del cual surgirán su hijo Eustaquio, luego juez de paz y Ciriaca Palau, reconocida como una de las primeras educadoras bahienses, en la segunda década del siglo XIX, como analizaremos más adelante.

c) Polidoro Coulin

Correspondió a este vecino no solo ser uno de los responsables de transportar treinta carretas con recursos y víveres para el establecimiento de la fortaleza, sino suscribir junto a la plana mayor el acta

${ }^{169}$ AGN, Sala X, 14-10-6.

${ }^{170}$ AHMMBB

${ }^{171}$ AGN, Sala X, C24. A9, n. ${ }^{\text {o }} 24$. 
fundacional de Bahía Blanca. En mayo de 1828, envía a la superioridad «La relación de los recursos que se elevaran a este establecimiento maderas, útiles, erramientas y utiles de subsistencia pa. Formar la expedición y establecimiento según le ordenó v.s...».

En esta especie de buscadores de huellas de una época pasada, pudimos encontrar que en la relación existe no solo una simple enumeración de artículos materiales sino ejemplos que nos traducen los elementos de construcción de sus futuras viviendas proyectadas y que las diferenciarían de las de Patagones. En cuanto a las futuras construcciones del fuerte observamos que se haría uso de palmas, «tixeras sauces» puertas, ventanas, hojas de portón, tirantes, marcos de portón, cañas, plomadas. Otros que se refieren a actividades económicas como la agricultura y pesca: hachas de mano, hachas de monte y para labrar tierra, azadas, pisones, anzuelos. No obstante, nos detenemos en el objetivo de esta tesis, encontramos en este documento muestras de útiles necesarios para la escritura: ellos son, tres atados de plumas, tres botellones de tinta y sesenta resmas de papel. Tal vez esto último responda a la función que tendría el escribiente como empleado del gobierno bonaerense. También figuran dos guitarras con encordado que vincularía no solo al conocimiento musical de la tropa o milicianos, sino generar espacios de recreación y sociabilidad.

Por otra parte, del documento se desprende el inicio de vinculaciones económicas para un abastecimiento más dinámico de la población. Este aspecto terminaría rompiendo el aislamiento que hasta ese año perduraba en la región sudoeste. En documento adjunto en febrero de 1828, Rondeau solicitará al Ministro de Guerra autorización para realizar esta operación ${ }^{172}$.

Con conclusión parcial hemos podido observar sustanciales diferencias entre la fundación de la Fortaleza Protectora Argentina con Carmen de Patagones, a consecuencia de dos políticas de ocupación de la tierra sustancialmente opuestas.

A diferencia de Carmen de Patagones, la Fortaleza Protectora Argentina, fue fundada como producto del reclutamiento forzoso de campesinos quienes debieron entregarse por mecanismos coactivos a lo estipulado por los sectores dominantes agrarios. La emigración de estos futuros vecinos, provenientes de los sectores más pobres, se caracterizó por su escasa calificación educativa o en los oficios.

Los vínculos con los indígenas demostraban ciertas políticas contradictorias entre lo ordenado y las prácticas. La necesidad de poner freno a los avances indígenas y ataques a las fortificaciones, dejaba traslucir un juego de manipulación de acuerdos y pactos que favorezcan los planes primarios. Pero por otra parte, surge actos de mayor violencia en los encuentros, que constituyen una red de rasgos que se refractan en los testimonios y documentos.

La fundación estuvo encuadrada en el plan de militarización de la campaña, pero que - en un marco interpretativo - caracterizó a la nueva Fortaleza por una oficialidad «distinguida» por profesión, nivel de educación, ingresos y un pasado que los representaba: su participación en las campañas libertadoras.

\footnotetext{
${ }^{172}$ Apéndice V.
} 
El análisis discursivo de estos actores y la vecindad favoreció encontrar en palabras, léxico o estructuras más complejas, re construir relaciones en diferentes estratos sociales como descubrir elementos simbólicos (instrumentos de conocimiento científico, relaciones con la naturaleza, lo que se dice, se piensa o los espacios de acción).

Por último una distribución de las primeras parcelas producto de intereses particulares de miembros de la clase dominante, en función del conocimiento que tenían de instrumentos de comunicación (legislación, vinculación con agrimensores o técnicos, espacios favorables de asentamiento).

\section{Quiebres y continuidades de las mentalidades educativas de la etapa colonial al gobierno independiente (1779-1821)}

El proceso revolucionario de 1810 tuvo como preludio una fase del Despotismo ilustrado que definieron los integrantes de la Corona Borbónica a partir del siglo XVIII. Esto marcó un proceso de acción y reacción por parte de los impulsores en la política, en la economía y en la cultura. La educación no estuvo exenta de este proceso en cambios de mentalidades, que estuvieron de la mano, por un lado - según sostiene Quijada - en la revalorización de procesos políticos hispánicos que ampliaban las bases de un electorado multiétnico ${ }^{173}$. Las condenas de pensadores y teólogos españoles a un nuevo modelo de soberanía, fortaleció conceptos como los del «poder del rey», poniendo en duda la transferencia divina que lo había sostenido anteriormente. La interpretación de Francisco de Suárez en tanto, que dio legitimidad política de la comunidad, preanunciaron una nueva indepencia «crítica» de la sociedad que se plasmó en los procesos revolucionarios de fines del siglo XVIII.

En este espacio nos detendremos a realizar un breve y conciso análisis de la contribución del pensamiento hispánico y su aplicabilidad en el Virreinato del Río de La Plata desde fines del siglo XVIII hasta el proceso independentista de las provincias unidas. Buscaremos sistematizar el ideario Ilustrado hispánico, sus antecedentes y concreta aplicabilidad en nuestro contexto geográfico. Realizamos un examen sobre la bibliografía específica que ha estudiado estas etapas, construyendo de esta forma un mapa historiográfico sobre la función y aplicación de los esquemas teóricos de los autores asociados a este tema. Al analizar a los mismos encontramos divergencias entre ellos sobre los efectos de la Ilustración europea en la cultura y educación de Hispanoamérica y las mayores o menores conexiones que existieron con el enciclopedismo francés, alemán o inglés o norteamericano. Por otra parte están quienes sostienen que la Ilustración tal como llegó a Hispanoamérica tuvo un carácter conservador y no revolucionario, atendiendo a la tradición católica del Iluminismo español del siglo XVIII.

Por último, identificamos los hitos históricos que permiten visualizar las conexiones entre los filósofos españoles y franceses con los intelectuales criollos que participaron en el proceso revolucionario y la

173 Quijada, M. «La potesta populi. Una revisión del pensamiento político hispánico y la modernidad», en: Bragoni, B. y Mata, S. E. (comps.) Entre la colonia y la República, Buenos Aires: Prometeo, 2008, págs. 29-49. 
gesta independentista. Tuvimos como marco referencial la selección de los componentes que se desprenden de su lectura y que actuaron en nuestra sociedad en la esfera comunicativa, en el sentido que le otorga Habermas ${ }^{174}$. Tomamos al lenguaje y las prácticas discursivas de estos hombres como una forma de institucionalizar nuevas modelos de educación para el Virreinato.

El siglo XVII había anticipado en España cambios profundos en la intervención del Estado en la educación: se abren las puertas para incorporar a nuevos actores a la movilidad vertical o ascendente, al conocimiento de técnicas para acrecentar la riqueza, al mejor manejo de instrumentos y perfecta experiencia en el uso de aparatos que requieren nuevas técnicas. El mercader necesita conocer principios de la contabilidad, el ingeniero y el militar, el cálculo, el arquitecto la proyección, al marino, los conocimientos de cartas geográficas, la brújula y la física ${ }^{175}$. El absolutismo de los Austrias aliado con los principios educativos de la Edad Media, había entregado la responsabilidad de enseñar a las órdenes religiosas, donde el reinado de la teología y la filosofía eran indiscutibles. Aunque la intransigencia de los monarcas con las nuevas ideas y adelantos científicos, que había invadido Europa hacia el siglo XVI y XVII, estaban motivadas por el temor que las nuevas doctrinas pudieren alterar los dogmas católicos y romper la unidad religiosa por ellos defendida, no pudieron impedir la lenta introducción de nuevos conocimientos en los hombres dedicados al comercio, fundamentalmente. La propia burguesía comienza a propiciar lo que Maravall denomina «mito de trabajar más». Este punto es de suma importancia en lo que respecta al reconocimiento social que poco a poco adquiere el trabajador agrario, procurando racional y metódicamente eliminar la pobreza. La acumulación de riqueza por parte de la burguesía y la concentración de bienes terrenales por parte de la Iglesia, con una estructura financiera altamente desarrollada, comenzará a quebrarse poco a poco ante una nueva concepción pública de la educación y una nueva atención del Estado a la enseñanza ${ }^{176}$.

La llegada de la dinastía borbónica determinó un cambio en los lineamientos pedagógicos de la península, fundalmentalmente dados por la introducción del ideario iluminista que estos monarcas trajeron de Francia. Estamos — según Maravall - en un proceso de conexión entre el individuo y la libertad, fenómenos que conducirán a la construcción del estado moderno. Puede advertirse el crecimiento de alumnos provenientes de la alta burguesía quienes van en procura de una formación humanista que facilitara un mayor prestigio social y la necesidad de adquirir mayores conocimientos contables para la aplicación de operaciones contables cada vez más complejas.

Un Estado moderno que supone cierta educación escolar y aprendizaje post-escolar para cualquiera que quisiese dedicarse con éxito en alguna actividad económica ${ }^{177}$. Existe, por ende, una interrelación entre los nuevos paradigmas de estado y educación que fortalecerán en el siglo siguiente los Borbones, con nuevos conceptos de autoridad que legitiman relaciones de comando y obediencia entre súbditos y

\footnotetext{
${ }^{174}$ Habermas, J. La ética del discurso y la cuestión de la verdad, Buenos Aires: Paidós, 2006, pág. 46.

${ }^{175}$ Cfr. Maravall, J. A. «Sobre la revolución educativa en Castilla (siglo XVII)». Estudios de historia del pensamiento español, Madrid: Ediciones Cultura Hispánica, 2001, págs. 168-178.

${ }^{176}$ Maravall, J. A. Estado Moderno y Mentalidad social (siglos S.XV a XVII), Tomo II, Madrid: Ediciones de la Revista de Occidente, 1972, pág. 249.

${ }^{177}$ Maravall, J. A. op. cit., pág. 161.
} 
gobernantes ${ }^{178}$. España a diferencia de otros países europeos colonizadores transmitió a sus dominios una concepción político-teológica, que puede observarse claramente en las interpretaciones y adecuaciones educativas del pensamiento ilustrado y su aplicación en este territorio.

En una primera fase examinamos los esquemas teóricos de algunos autores que seleccionamos dentro de la abundante literatura historiográfica que analizaron este tema. No obstante dado que excedía el objeto de esta tesis nos impusimos jerarquizar la relevancia que le atribuyeron al pensamiento europeo y norteamericano por sobre el español en relación a la minoría ilustrada que condujera las guerras de la emancipación. Pretendemos identificar las cuestiones metodológicas e ideológicas que aportaron al conocimiento de las prácticas de escolarización del período analizado.

\subsection{Análisis y relación de esquemas teóricos sobre el Iluminismo en el Río de la Plata}

Nos centramos en cómo se fueron concretando ideas controvertidas o enfoques respecto a la incidencia de la Ilustración sobre la historia social e intelectual de Hispanoamérica y en especial del Virreinato del Río de la Plata. Buscaremos diferenciar, en algunos casos, la historia cultural para poder examinar una vez más la cuestión spenceriana que determina la historia del currículo, es decir, qué conocimiento es el más valioso en un momento histórico determinado ${ }^{179}$. En los primeros autores que analizaremos, encontraremos que esta problemática queda atrapada — en parte - por la preeminencia o causalidad de factores políticos y económicos vinculados a los movimientos emancipadores.

En el siglo XIX la historia concebida como una construcción del sentimiento de identificación nacional estuvo condensada en las obras de Bartolomé Mitre y Vicente Fidel López. Para el primero, las teorías racionales de la emancipación norteamericana, como la declaración de los derechos del hombre, tuvieron su inmediata repercusión en Francia, que la acogió como nuevo decálogo político en el pensamiento de Montesquieu y Rousseau. Mitre sostuvo que «el acontecimiento extraordinario que más contribuyó a formar esta conciencia y abrir los ojos a los mismos gobernantes» fue la emancipación de América del norte y la alianza que Carlos III establece con Francia para combatir a su enemigo, Inglaterra. Según este autor «las nuevas ideas penetraban primero en las cabezas ilustradas y se infiltraban en la masa por el vehículo del instinto y la pasión...» ${ }^{180}$. Al interpretar algunas ideas de este autor, observamos cómo se inscriben en ellas la relación de aquellos que ostentan el «poder» leer e construir teorías e hipótesis para delinear procesos y cambios sociales. En las masas existía la influencia de las nuevas ideas. La expresión «cabezas ilustradas» era el indicador del consentimiento tácito de los

${ }^{178}$ Siebebzehner, B. B. La universidad americana y la Ilustración. Autoridad y conocimiento en Nueva España y el Río de la Plata, Madrid: Mapfre, 1994, pág. 18.

${ }^{179}$ Popkewitz, T. S.; Pereyra, M. A. y Franklin, B. M. «Historia, el problema del conocimiento y la nueva historia cultural de la escolarización: una introducción», en: Popkewitz, T. S.; Franklin, B. M. y Pereyra, M. A. (comps.) Historia Cultural y educación. Ensayos críticos sobre conocimiento y escolarización, Barcelona-México: Ediciones Pomares, 2003, págs. 15-58.

${ }^{180}$ Cfr. Mitre, B. Historia de San Martín y de la Emancipación Sudamericana, Buenos Aires: Anaconda, 1950. 
ilustrados al acceso a nuevas prácticas educativas y lecturas. O mejor dicho, si se abrían los canales de ingreso a las nuevas instituciones educacionales para todos los sectores sociales.

A partir de la década del veinte del siglo XX, Ricardo Levene adquiere un creciente peso dentro de la Universidad de La Plata en calidad de decano de la Facultad de Humanidades y Ciencias de la Educación. Siendo una de las figuras de mayor rigor metodológico en los estudios históricos estimuló la investigación y extensión con sus publicaciones. De esta escuela histórica platense, surgirán nombres como Rómulo Carbia y Carlos Heras y que transmitió a sus egresados más destacados como Enrique Barba y Roberto Marfany ${ }^{181}$.

En su obra Ensayo histórico sobre la Revolución de Mayo y Mariano Moreno ubica a este último como una de las figuras más representativas de la Revolución junto con la de San Martín y Rivadavia. Pone el acento en las ideologías hispánicas e indianas donde estos hombres forjaron su pensamiento. Bajo esta premisa desarrollada explícitamente, resta valor a la incidencia del pensamiento francés o inglés, entendiendo al movimiento revolucionario como popular, federal y republicano. En su Historia de la Nación Argentina señala como el genio jurídico y político de España, comparable al de Roma, fue el que promovió el desenvolvimiento de las instituciones políticas españolas en América y la renovación intelectual en los centros universitarios y de segunda enseñanza. En el tomo III de esta obra, Rafael Altamira denomina «Despotismo Ilustrado» a la «novedad ideológica» traída por los Borbones que direcciona la educación hacia un ámbito más técnico — por una parte - y una política de ataque al analfabetismo $^{182}$

En la Historia Económica del Virreinato de Levene pone en primer plano la incidencia que sobre Felipe V y Carlos III que tuvieron los pensadores hispánicos como Rafael Melchor de Macanaz, Campomanes y Gaspar Melchor de Jovellanos, quienes no solo estimulaban en el Río de la Plata la propagación de nuevos principios económicos sino una nueva mirada sobre la antigua prohibición de lecturas y el fomento de la educación popular ${ }^{183}$. Levene, por tanto, reconocerá el abanico filosófico europeo (francés, inglés e hispano) y norteamericano que dieron forma a la Ilustración latinoamericana.

Coriolano Alberini, que dominó con su presencia intelectual por más de cuarto siglo la vida universitaria argentina, realizó un estudio riguroso y metódico de la historia de la filosofía argentina. Entendió que la misma surgió de la necesidad de dar una fundamentación racional a nuestra independencia política y organización nacional. Según su mirada «la Argentina, como los demás países latinoamericanos, carecía de pensamiento filosófico original». Nuestro pensamiento — para este autorestuvo siempre inspirado «en conceptos oriundos de superiores filosofías extranjeras». Por ende, si no existe filosofía argentina, había una manera argentina de sentir los valores fundamentales del espíritu

${ }^{181}$ Cfr. Devoto, F. y Pagano, N. Historia de la Historiografia Argentina, Buenos Aires: Sudamericana, 2009, págs. 155-157.

${ }^{182}$ Levene, R. Historia de la Nación Argentina (desde los orígenes hasta la organización definitiva de 1862), 2a edición, Tomo III, Buenos Aires: El Ateneo, 1947, págs. 15-62.

${ }^{183}$ Levene, R. «Historia económica del Virreinato del Río de la Plata», en: Obras de Ricardo Levene, Tomo II, Buenos Aires, Academia Nacional de la Historia, 1962, págs. 194-208. 
humano ${ }^{184}$ La inexistencia de una pensamiento original marcada con la fuerte incidencia de la Iglesia sobre los actores de la Revolución, propiciaron que los principales paladines de la contrarreforma, como Francisco Suárez, fueran inspiradores de la enseñanza universitaria de Córdoba y del Colegio de San Carlos. Para este autor muchos prohombres de la emancipación todos estaban penetrados por el espíritu del Aùfklarung (Ilustración) francés. Aunque reconoce que estas ideas, no su origen francés, llegan por la vía de España. La Península, estaba según Alberini, invadida por ideas fisiocráticas, por teorías del derecho natural y por el espíritu regalista. El Contrato Social de Rousseau y las obras de Raynal, Mably, Voltaire, Montesquieu, Condillac y hasta Adam Smith fueron difundidos en la Universidad de Salamanca. Centro superior de estudios donde se formarán algunos personajes de la burguesía liberal rioplatense como Manuel Belgrano ${ }^{185}$.

No podemos ignorar el análisis de José María Mariluz Urquijo que realiza en la Historia Argentina de Roberto Levillier. El autor encuentra en el iluminismo dieciochesco y el despotismo ilustrado las fuerzas que allanaron el camino a los innovadores, abriendo concesiones para los rebeldes de la Revolución de 1810. Pone énfasis en la importancia que tuvo la lectura de los escritores españoles en las creaciones educativas realizadas por Belgrano en el Consulado del Virreinato del Río de la Plata ${ }^{186}$. Algunos miembros de la Academia Nacional de la Historia le imprimieron un valor categórico en el análisis de la Ilustración sobre diferentes figuras del pensamiento histórico y a través de enjundiosas publicaciones anuales o en actas de congresos ${ }^{187}$. Para Víctor Tau Anzóategui y Eduardo Martiré, el despotismo ilustrado es definido adoptando el concepto de Paul Hazard como un «cristianismo ilustrado», que marcará cambios en «materia industrial» al introducir la enseñanza de los oficios útiles y la protección de las manufacturas locales. Para estos autores los cambios surgieron en España siguiendo el ejemplo francés. Mercedes J. Aldalur, Efraim Cardozo, Edmundo Narancio, Justo Prieto y Enrique de Gandía, entre otros, realizan medulosos trabajos en el Tercer Congreso Internacional de Historia de América sobre las grandes transformaciones sociales y políticas en América a través del enciclopedismo francés, la fisiocracia y la revolución norteamericana. En la dimensión de la validez de estos análisis no escapan las profundas crisis del pensamiento filosófico, religioso y sus repercusiones en la vida diaria y cultural

${ }^{184}$ Alberini, C. Problemas de la historia de las ideas filosóficas en la Argentina, La Plata, Facultad Humanidades y Ciencias de la Educación, Universidad de La Plata, 1966, págs. 41-43.

${ }^{185}$ Idem, pág. 44.

${ }^{186}$ Mariluz Urquijo, J. M. «La crisis del régimen (1790-1810)», en: Levillier, Ro. Historia Argentina, Tomo II, Libro 20, Buenos Aires: Plaza y Janes, 1968, págs. 1335-1389.

187 Podemos mencionar -entre otros_ a Leoncio Gianello, «Aspectos destacables de la revolución hispanoamericana: el ideal de continentalidad», en: Academia Nacional de la Historia. Investigaciones y Ensayos, n. ${ }^{\circ}$ 20, enero-junio, 1976, págs. 131-143. Tanzi, H. J. «El racionalismo político en el Virreinato del Río de la Plata», en: Academia Nacional de la Historia. Investigaciones y ensayos, n. ${ }^{\circ}$ 8, Buenos Aires, 1970. De este mismo autor, podemos nombrar: El poder político y la independencia argentina, «Prólogo» de Demetrio Ramón Pérez, Buenos Aires: Edición Cervantes, 1973 e «Interpretación de la Revolución de Mayo según oraciones de sacerdotes contemporáneos del suceso», en: Academia Nacional de la Historia. Investigaciones y ensayos, $\mathrm{n}^{\circ}{ }^{\circ} 14$, Buenos Aires, 1973, págs. 557-573. 
que tuvieron en el Río de la Plata ${ }^{188}$. El tema de la Revolución de Mayo jugó un papel central en los nuevos análisis historiográficos. No obstante para Gabriel Di Meglio, estos autores siguieron las líneas básicas establecidas por Mitre, matriz de los discursos educativos de varias décadas ${ }^{189}$. Este autor contemporáneo considera que el discurso académico respondió a una «tradición liberal», luego llamada «historia oficial». Manifiesta, según mi criterio, una lectura que minimiza la acción comunicativa y el potencial de racionalidad en el corpus metodológico de estas obras, como en el lenguaje aplicado por estos estudiosos de la historia.

Diego Pró analiza la periodización histórica bajo el método generacional de Ortega y Gasset para el estudio de la cultura argentina. Luego de abordar los diferentes criterios generacionales aplicados por autores como Matienzo, Rivarola, Ingenieros, Furlong y Quesada, se detiene en el período independiente en autores como Carlos Zuretti y Juan María Gutierrez, este último en especial en su obra Origen y desarrollo de la enseñanza pública superior ${ }^{190} \mathrm{El}$ autor considera que hay dos núcleos en la generación de 1810: el que prolonga el pensamiento tradicional de la época pre-independiente y el de los hombres que exaltan la libertad. A los primeros los había inspirado la enseñanza de los franciscanos, mientras que los segundos traían el fermento renovador del Iluminismo, ideas que habían arribado al Río de la Plata desde la de España, primero y más tarde por los libros de Francia, Inglaterra. Reconoce entre ellos a hombres como Moreno, Castelli, Dean Funes, Belgrano, Vicente López y Planes y Bernado Monteagudo. Pero este iluminismo, según Pró, tiñe el pensamiento y la acción de la Generación de 1821, esta vez bajo la forma del pensamiento de la Ideología francesa, «que puede considerarse como un iluminismo francés» ${ }^{191}$.

José Luis Romero, según Jorge Myers, inicia su vida intelecual en 1930 como miembro de un grupo de vanguardia artística e intelectual ${ }^{192}$. Luego de transitar la historia política y cultural del Medioevo, entre 1944 al 45 escribe una de sus obras más resonantes: Las ideas políticas en la Argentina. En ella sostuvo que la Revolución Francesa había parecido en un principio el triunfo de los ideales de fraternidad y justicia propugnados por Rousseau y Montesquieu. Pero el curso de los sucesos en Francia, incitó a muchos americanos a volver la mirada hacia Inglaterra, que orientó la reflexión política de los pensadores rioplatenses. Considera al grupo criollo como una minoría «europeizante e ilustrado» sostendrá que «europeizante e ilustrado», y que desde el punto de vista ideológico descendía de manera directa de los liberales españoles de la época borbónica, aunque con lecturas del pensamiento francés e

188 Academia Nacional de la Historia. Tercer Congreso Internacional de Historia de América. Celebrado en Buenos Aires del 11 al 16 de octubre de 1960 con el auspicio de la Comisión Nacional Ejecutiva del 150 aniversario de la Revolución de Mayo, Tomo I, Buenos Aires, ANH, 1961. 189

Di Meglio, G. «La crisis del consenso liberal (1920-1940/50)», en: Fradkin, R. y Gelman, J. (coords.). Doscientos años pensando la revolución, Buenos Aires: Sudamericana, 2010, págs. 253-258.

190 Pro, D. F. «Periodización del pensamiento argentino», en: Cuyo. Anuario de Historia del Pensamiento Argentino, Tomo I, Instituto de Filosofía. Mendoza. Universidad Nacional de Cuyo, 1965, págs. 7-42.

${ }^{191}$ Idem, págs. 18-22.

${ }^{192}$ Myers, J. «Pasados en pugna: la difícil renovación del campo histórico argentino entre 1930 y $1955 »$, en: Neiburg, F. y Plotkin, M. (comps.). Intelectuales y expertos, Buenos Aires: Paidós, 2004, págs. 91-94. 
inglés. Por ende, el grupo ilustrado porteño tendría para este autor una doctrina liberal de características sui generis ${ }^{193}$. Romero acentuará como factor distintivo la escasa preparación doctrinaria de la población del interior, cuya educación suministrada por el clero se había caracterizado por su autoritarismo y un dogmatismo rayano en la superstición.

Gregorio Weinberg caracteriza «el modelo de la Ilustración por su espíritu innovador nada revolucionario en sus objetivos iniciales»... aunque con consecuencias evidentes sobre la sociedad y la administración así como actualización cultural y administrativa. Si bien toma en cuenta la corriente ilustrada española, no deja de poner acento en las influencias francesas e italianas. Del tradicionalismo autoritario de las aulas entonces vigente, «la letra con sangre entra», la ilustración concibió a la educación como instrumento que suponía superar inadecuaciones económicas y sociales. Weinberg ahonda en la incidencia que tuvo el pensamiento de Aranda, Floridablanca, Cabarrús, Campomanes y Jovellanos, en los «modelos educativos latinoamericanos». Para este autor, las Sociedades Económicas de Amigos de País creadas a ejemplo de las españolas serían determinantes para la educación en las campañas más que en los centros urbanos ${ }^{194}$. Podemos recordar en este punto como en el avance de la frontera - que fuera analizado en el punto anterior- Pedro Andrés García formenta la creación de sociedades patrióticas que llevaran «las luces» a los «desvalidos labradores» de la campaña como forma de transformación de los hombres en seres «virtuosos».

David Brading resalta en forma particular el carácter incendiario que tuvo para la monarquía española «La carta dirigida a los españoles americanos» del jesuita peruano Juan Pablo Viscardo y Guzman (1748-1798) al plantear con críticos argumentos hacia la corona, «los derechos inalienables del hombre y los deberes indispensables de todo gobierno». Dentro de estos derechos estaba el acceso a la educación por parte del individuo. Este pensador americano, contrapone una idea hasta ese momento sostenida, presentando al indio como laborioso, ocupados en la agricultura y el tejido. Según Brading, para Viscardo los criollos como el clero eran respetados por los indígenas que se esforzaban en defenderlos de los chapetones. Atestiguó que el reinado de Carlos III constituía un punto de cambio en las relaciones entre la Corona y los criollos. Mariano Moreno, estudiando en Chuquisaca, leyó la obra de Viscardo, cuyo rasgo más notable eran sus citas a Montesquieu, sus elogios a la revolución Norteamericana y su indignación contra las medidas adoptadas por el Despostismo Ilustrado que caracterizaba el régimen de la Corona en los últimos años ${ }^{195}$.

Para Francisco Morales Padrón con la proyección del Despotismo Ilustrado se genera en América una renovación que fomentaron los estudios científicos —en especial vinculados a las ciencias exactas - y una mayor circulación de textos que fortalecían el racionalismo cartesiano y el utilitarismo. Este autor considera que la ilustración del pensamiento español e hispanoamericano fue fruto de minorías, no

${ }^{193}$ Romero, J. L. Las ideas políticas en Argentina, Buenos Aires: Fondo de Cultura Económica, 1975, págs. 65-69.

${ }^{194}$ Weinberg, G. Modelos Educativos en la historia de la América Latina, Buenos Aires: Unesco-Cepal-PnudKapelusz, 1986, págs. 75-87.

195 Brading, D. Orbe indiano. De la monarquía católica a la república criolla, 1492-1867, Mexico: Fondo de Cultura Económica, 1991, págs. 576-581. 
siendo este un fenómeno puramente francés. «El siglo XVIII español se mantiene dentro de la Ilustración cristiana», afirma el autor, al interpretar, primero, la existencia de una influencia procedente de Alemania y países nórdicos. Segundo, al no dar primacía de lo material sobre lo espiritual. De allí que considere un error confundir Ilustración con Enciclopedismo, siendo esta última la ideología del siglo XIX, y la primera del siglo XVIII ${ }^{196}$.

En este mapa que pretendemos delinear sobre algunos pensadores e historiadores y sus particulares miradas sobre el proceso de la ilustración americana, encontramos diferentes líneas de investigación que fluctuaban entre lo filosófico, sociológico e histórico, que van quebrando la construcción teleológica de la historia academicista. El filósofo Arturo Roig consideró que la ilustración americana no fue una copia de la francesa debido a la distancia temporal entre la Revolución y los movimientos independentistas de América, temerosos de los efectos que podría producir el jacobinismo sobre la clase dirigente ${ }^{197}$. Considera que la preeminencia de la ideología francesa sería un cliché acuñado por los románticos en su visión retrospectiva del movimiento independentista. Aunque observa que es a partir de la segunda mitad del siglo XVIII - cuando surge con fuerza en Latinoamérica y en el Virreinato- la noción de «patria» de la que hablaban los ilustrados. Para Roig, la ilustración latinoamericana, se convierte en un «programa difuso y complejo que pretendió abrirnos al autoconocimiento» como latinoamericanos ${ }^{198}$.

Kossok establece una distinción entre el jacobinismo francés y el americano, considerando al primero como la culminación de un proceso revolucionario radicalizado, que concluye manifestándose como «jacobinismo con el pueblo». La versión americana de esta ideología se expresó como «jacobinismo para el pueblo pero sin el pueblo» salvo excepciones como Castelli y Artigas. Los efectos políticos de ambos jacobinismos, están definidos por la crisis de la burguesía que generaría el francés, mientras que el latinoamericano favoreció los levantamientos populares, que modificaron la estructura social de la etapa colonial para facilitar el predominio de una nueva clase dominante: los ilustrados americanos. En su discurso plantean nuevas reivindicaciones sociales para los sectores populares, entre las que figuraba la educación con la matriz propia del racionalismo ilustrado ${ }^{199}$.

En 1953 José Luis Romero emprendió la publicación de la revista Imago Mundi buscando colocar a la historia de la cultura en el centro del debate, lo que permitió una renovación en el campo histórico de sus debates y abordajes. Tulio Halperin Donghi integraba el grupo de sus ilustres colaboradores quien se convertirá en uno de los historiadores de permanente consulta en especial a partir de su Historia

${ }^{196}$ Morales Padrón, F. «Historia General de América», en: Manual de Historia Universal, Tomo VI, Madrid: Espasa Calpe, 1975, págs. 832-33.

${ }^{197}$ Roig, A. A. «La ilustración y la primera independencia», en: Cuadernos Americanos, México, n. ${ }^{\circ}$ 4, julioagosto, Año XLIV, 1985, págs. 71-81.

${ }^{198}$ Roig, A. A. El pensamiento latinoamericano y su aventura, Buenos Aires: CEAL, 1994, pág. 31.

${ }^{199}$ Cfr. Kossok, M. «Notas acerca de la recepción del pensamiento ilustrado en América Latina», en: Homenaje a Noêl Salomón, Barcelona, Universidad Autónoma de Barcelona, 1979. 
Argentina, editada en $1972^{200}$. Para Halperín, el Despotismo fue característico de aquellas zonas marginales donde no existían fuerzas sociales capaces de generar un nuevo clima técnico y económico en Europa occidental. La Ilustración será la solución para Austria, Prusia, Toscana y España, que requerían enérgicas orientaciones para renovar el espíritu. Encuentra que la renovación ilustrada en el Río de la Plata, surgieron en Córdoba, a pesar de la oposición cerrada a las innovaciones del siglo XVIII y en Buenos Aires. De la primera ciudad, destaca a Fray José Antonio de San Alberto en cuanto a su interés por ilustrar al clero y a su grey. Pero lo esencial que destaca este autor sobre este obispo, es su proyecto es la concentración de la población en aldeas, para que el cura pueda enfrentarse a «entendimientos limitados e incultos». La transformación sería la enseñanza y organizada, que más allá de la pura teoría, de leer y escribir incluya el adiestramiento en «ejercicios liberales y mecánicos». Modelo que copia de las escuelas francesas y alemanas, que vinculaban el saber y la vida activa ${ }^{201}$.

Halperin enfatiza los cambios en la vida cotidiana rioplatense que tienen su origen en la expulsión de los jesuitas, que se advierte con claridad en la secularización postrevolucionaria ${ }^{202}$. Recientemente en otros títulos publicados del autor como Historia contemporánea de América Latina, analiza el fenómeno iluminista desde una mirada más economicista que cultural, pondrá su mirada en la incidencia en las producciones regionales del litoral mesopotámico la falta de mano de obra ante la expulsión de los jesuitas y los perjuicios sobre la agricultura cerealista de la campaña bonaerense dominada por comerciantes. Encuentra en el desequilibrio social, las tensiones de los grupos étnicos, el peso económico de la Iglesia y sus órdenes, la razón de las transformaciones administrativas y educacionales que se producen en Hispanoamérica y el Río de la Plata. Registra la necesidad de erigir un aparato administrativo más sólidamente controlado por la Corona, con la creación del Ministerio de Indias. «Sin duda no hace sino trasladar a las Indias una innovación previamente introducida en España imitando el modelo francés» ${ }^{203}$. Según su criterio los consulados, luego de esta reforma, comienzan a invertir en puertos, nuevas rutas de navegación e instituciones de enseñanza técnica. Reconoce como en la era de la revolución son los párrocos quienes se imponen frente a sus fieles, no solo por temor al poder, sino como referentes ilustrados en un proceso de transformación. Pero su mirada original sobre la temática está puesta en comprender cómo la reforma administrativa borbónica inspirada en otros despotismos ilustrados se extiende a los cuadros militares. Entiéndase que la Corona vio la necesidad de cualificación educativa de los cuerpos militares.

Newland sostiene que durante las primeras décadas del siglo XIX el estado toma el rol de docente. Este nuevo paradigma de Estado respondía a un clima ideológico sembrado por autores y políticos

${ }^{200}$ En 1972 realiza la publicación de su obra Revolución y guerra. Formación de una élite dirigente en la Argentina criolla, Buenos Aires: Siglo XXI, págs. 65-77. Donde incorpora el concepto del avance fronterizo y las consecuencias económicas y religiosas provocadas por las reformas carloterceristas.

${ }^{201}$ Halperín Donghi, T. Tradición política España e ideología revolucionaria de Mayo, Buenos Aires: CEAL, 1985, págs. 61-76.

${ }^{202}$ Halperín Donghi, T. Revolución y guerra, formación de una elite dirigente en la Argentina criolla, Buenos Aires: Siglo XXI, 1972, pág. 68.

${ }^{203}$ Halperin Donghi, T. Historia Contemporánea de América Latina, Madrid: Alianza, 2011, págs. 58-59. 
españoles como Campomanes y Jovellanos, para quienes el trabajo y la política, eran símbolos de civilización y «la barbarie de ociosidad y anarquía» ${ }^{204}$.

Desde hace varias décadas, la historiografía fue abandonando la construcción de un relato eminente fáctico para colocar al sujeto en el centro de la historia. Este cambio de paradigmas, comienza desechando conceptos «fundantes» que colocaban al proceso filosófico de la Ilustración como unicausal de las «revoluciones americanas» y de los cambios expresados en la sociedad, en la economía y en la educación rioplatense. Bajo la clara influencia de la Escuela de los Annales se produce el abandono de una concepción determinista de la historia introduciendo nuevos aportes con un nuevo términos como «patria», «nación», «ciudadano», «relaciones de discurso e ideología» otorgado dentro del contexto revolucionario que le confieren a este debate un nuevo lugar.

Entre muchos de estos autores, buscamos seleccionar aquellos cuyos debates o criterios predominantes en el análisis político-educacional, han escapado de criterios periodizadores demasiado rígidos. En 1979 José Carlos Chiaramonte elabora uno de los análisis críticos sobre las contradicciones que la historiografía y pensadores del siglo XIX y XX habían presentado en el estudio de la Ilustración Iberoamericana en cuanto a fundamentos y antecedentes de la emancipación americana. Ratifica la indudable y profunda huella que marcó el pensamiento europeo del siglo XVIII en el americano. Considera la inexistencia de una brusca ruptura del nuevo pensamiento en los dos primeros siglos de la etapa colonial y se inclina por una penetración «gradual y moderada del espíritu del siglo». Esta conciliación de los rasgos ilustrados con los tradicionales lo induce a llamarlo un eclecticismo ideológico. Desde el punto de vista educacional, las novedades de Campomanes y Jovellanos contagiaban a los súbditos americanos y mantenían una penetración ideológica menos agresiva como las del padre Feijóo. En tanto los jesuitas utilizaban recursos proposicionales que llevaban a una introducción cartesiana solamente científica y que no comprometieran los fundamentos teológicos ${ }^{205}$. Atento a argumentos históricos y filosóficos desemboca en una nueva fase en el estudio de la nación, cuyo primero paso fue advertir sobre los anacronismos que se cometen con este concepto, al asociar enunciados de identidad étnica con el de nación ${ }^{206}$. Las formulaciones políticas cubren nociones excesivamente amplias tomadas de la Ilustración o Modernidad y sus efectos sobre la sociedad y cultura latinoamericana, cuando lejos de mostrarse innovaciones radicales hay una persistencia de antiguas formas políticas y culturales hasta bien entrado el siglo XIX. Si bien aborda el ámbito restringido de la enseñanza del derecho y la presencia del iusnaturalismo bajo el reinado de Carlos III en las universidades de España y Latinoamérica en el siglo XVIII de autores célebres, comprueba la lectura por

${ }^{204}$ Newland, C. «La educación elemental en Hispanoamérica: desde la Independencia hasta la centralización de los sistemas educativos nacionales», Hispanic American Historical Review, 71: 2, Duke University Press, 1991, págs. 335-364.

${ }^{205}$ Chiaramonte, J. C. (compilación, prólogo, notas y cronología). El pensamiento de la ilustración, Buenos Aires: Biblioteca Ayacucho, 1979, págs. IX a XXXIX.

${ }^{206}$ Chiaramonte, J. C. «Fundamentos Iusnaturalistas de los movimientos de la Independencia», en: Boletín del Instituto de Historia Argentina y americana Dr. Emilio Ravignani, n. ${ }^{\circ} 22,3^{\mathrm{a}}$ serie, $2^{\mathrm{o}}$ semestre, Buenos Aires: Fondo de Cultura Económica, 2000, págs. 33-71. 
parte de los americanos de manuales de pensadores menos conocidos como Grocio, Pufendorf y Wolf ${ }^{207}$. Los criterios filosóficos de estos autores, son tomados según Chiaramonte, por buena parte de los líderes de la independencia para organizar los nuevos Estados en la búsqueda de regímenes representativos de su tiempo, como la preservación de los poderes «soberanos» de ciudades y provincias. Finalmente concluye que la «vigencia del derecho natural fue fundamento de la regulación de la vida social, heredada del período colonial y persistente durante mucho tiempo después de la Independencia» ${ }^{208}$.

Francois Guerra ha analizado la concepción esencialmente política de la Revolución Francesa en la construcción de las identidades culturales regionales en América fundadas en la lengua, religión y costumbres. Trata de delimitar la confusión que generan tanto los conceptos nación como identidad. Considera que la cuestión de las nacionalidades planteadas entre el siglo XIX y XX fueron consecuencia del triunfo de las ideas de la revolución Francesa, modelo de estado-nación. Aunque su originalidad estriba en detenerse en el aislamiento geográfico, las poblaciones reducidas, en el vecinalismo de determinados espacios, que facilitará en América latina el surgimiento del mal llamado «localismo o regionalismo». En cuanto al interés de nuestra temática, este autor construye una identidad de pirámides no solo en orden político sino en el cultural. Esta última cumple un papel central en los pueblos, villas y ciudades, «que fundan su identidad en su memoria colectiva». En la construcción de esta memoria participarán las élites intelectuales criollas, los religiosos y quienes sean capaces de suministrar instrumentos conceptuales y simbólicos a través de la lectura, de la escritura o de las fiestas profanas ${ }^{209}$.

Pilar González Bernaldo sostiene que existió una larga tradición historiográfica sobre la influencia de la revolución francesa en los movimientos independentistas de América latina. Pero la cuestión sobre la que gravita su tesis esta en interpelar hasta qué punto se extendieron las nuevas prácticas de sociabilidad de la política en el Río de la Plata en forma de clubes o sociedades populares ${ }^{210}$. Estos encuentros propiciados de los periódicos como el Telégrafo Mercantil, exigirían no solo nuevas formas de consolidación de grupos sociales, sino que la lectura de escritos en reuniones o juntas de vecinos requerirían la necesaria alfabetización de nuevos actores urbanos.

Noemí Goldman desde otra perspectiva se detiene en el discurso revolucionario francés que bajo el concepto de «hegemonía» de Gramsci fue utilizado por la burguesía dominante de la III República en diversos aparatos estatales, como era el educativo. Desarrolla y analiza la exaltación del sentimiento nacional en nociones como «república», «patria», «progreso»y «revolución francesa» en los manuales

${ }^{207}$ Locke, Rousseau, Benjamín Constant y Bentham entre otros integraba la lista de autores «célebres». Aunque pone especial acento en el padre Feijóo. Cfr. Chiaramonte, J. C. «Fundamentos iusnaturalistas de los movimientos de independencia», en: op.cit., págs. 52-56.

${ }^{208}$ Chiaramonte, J. C. op.cit. págs. 59.

${ }^{209}$ Guerra, F. X. «Identidades e Independencia», en: Guerra, F. X. y Quijada, M. «Imaginar la nación», Cuadernos de Historia Latinoamericana, n. ${ }^{\circ}$ 2, Hamburgo, 1994, págs. 93-134.

${ }^{210}$ González Bernaldo, P. «La Revolución francesa y la emergencia de nuevas prácticas de la política: la irrupción de la sociabilidad política en el Río de la Plata revolucionario, 1810-1815», Boletín del Instituto de Historia Argentina y Americana. «Dr Emilio Ravignani», n. ${ }^{\circ}$ 3, 3a serie, 1er semestre, 1991, Buenos Aires: Fondo de cultura Económica, págs. 7-27. 
escolares franceses en la búsqueda de la «unidad nacional». Reproduce la tesis de R. Robin que ve a la historia del aparato escolar como la historia de sus luchas internas bajo diversas formas. Por ello comprende que la materialización institucional de la tradición histórica «nacional-popular» nace en la Revolución Francesa. Goldman identifica en el discurso de Mariano Moreno los valores de aquella Revolución quedando atrapada por la fascinación que este personaje ofrece para el Río de la Plata en sus supuestas contradicciones, como un «rousseauista» y «jacobino», como un político liberal y fidelista ${ }^{211}$.

Según lo argumentado por algunos de los autores analizados, pudimos identificar los tiempos, métodos, prácticas o conocimientos más valiosos que la filosofía Iluminista seleccionó en la construcción de la historia educacional del Virreinato desde su creación hasta la segunda década del siglo XX. Aún asumiendo que muchos de ellos no focalizaron sus estudios en la especificidad de lo educativo. Esta historización estuvo dirigida a plantear los debates, dilemas y direcciones seguidas por la aceptación de categorías de pensamiento disímiles, pero que aportan con expresiones concretas sobre las nuevas ideas y favorecen una clasificación sobre sistemas de escolarización, abandono paulatino de los sistemas educacionales del Régimen, teorías de acción concretas y la función de diferentes actores sociales en el progreso del conocimiento y la escolarización.

Como conclusión parcial en este análisis historiográfico podemos establecer los siguientes ítems en la evolución analítica que se realizaron sobre la Ilustración y la relación con los cambios educativos que se generaron en el Río de la Plata, y en particular, en la campaña bonaerense.

1. La hegemonía de la historia política por sobre la historia cultural de mediados del siglo XIX y principios del XX, pusieron su acento en el triunfo del pensamiento francés, alemán e inglés. En la medida que se avanza en el siglo XX, hay una revalorización del iluminismo español e italiano y de algunos autores hispanoamericanos, quienes generarán cambios sustanciales en la política cultural y educativa en el Río de la Plata a partir del reinado de Carlos III. Se observa una disparidad en la historiografía argentina — que seleccionamos en forma arbitraria- pero que responde a distintas fórmulas interpretativas determinadas por escuelas, tendencias o aportes de otras disciplinas, que no solo se detienen en la filosofía sino la relación entre el conocimiento y la historia social. Todas estas corrientes historiográficas incorporan el concepto de la Ilustración, que no se detiene en la primera década del siglo XIX, sino que la trasciende en los cambios educativos del Río de la Plata hasta mediados de 1840.

2. En su amplia mayoría los autores analizados coinciden que la expulsión de los jesuitas (1767) redujo el predominio del espíritu barroco y escolasticismo universitario. Los nuevos conceptos filosóficos le confirieron mayor fortaleza y cohesión al poder de la Corona - en un principio- y el dominio real sobre los centros de educación secundaria y universitaria de Córdoba y Buenos Aires ${ }^{212}$. Estos últimos, en especial, respondían a los nuevos paradigmas filosóficos vinculados al

${ }^{211}$ Goldman, N. El discurso como objeto de la historia, op.cit., págs. 99-103.

${ }^{212}$ Vicente Quesada le atribuye un papel fundamental al uso que los jesuitas tenían de la imprenta y el poder de distribución de libros y tablas de enseñanza. El traslado de la imprenta de Córdoba a Buenos Aires dará origen a la Imprenta de los niños expósitos a cargo de los padres franciscanos. Quesada, V. La vida intelectual en la 
racionalismo cartesiano y el empirismo de Newton y Bacon que diseñan una nueva matriz intelectual en las escuelas. Desde lo social, existe una mayor consolidación política de grupos privilegiados hispánicos o hispano-criollos, que recibirán los beneficios de la educación formal en instituciones como el Colegio de San Carlos. Podemos deducir que existió en esta medida de la Corona una forma de conexión con las nuevas teorías de la ilustración suponían un nuevo modelo de autoridad, representando la victoria del poder temporal sobre el papado y la legitimidad por el control sobre academias y universidades ${ }^{213}$. Enfatizan la tesis de de Emanuel Kant (1784) según la cual la «ilustración es la liberación del hombre de su culpable incapacidad. La incapacidad significa la imposibilidad de servirse de su inteligencia sin la guía del otro». Este principio valora la capacidad del individuo en hacer uso de su razón y liberarlo de toda tutela. Por otra parte legitima el accionar de todo su ciudadano expresar públicamente su pensamiento, limitando la palabra y el dogma del clérigo ante su feligresía como de uso privado «...porque se trata siempre de un ejercicio doméstico, aunque la audiencia sea muy grande...» ${ }^{214}$. La consecuencia será la aparición de periódicos, semanarios, cartillas y catecismos que favorecieron no solo la difusión del nuevo pensamiento sino la aplicación de nuevas estrategias teóricas y metodológicas que pululaban en Europa, Iberoamérica y América del norte.

3. Desde lo político, consideran que la ilustración fue quien ambientó y justificó la revolución científica y cultural donde brotaron las revoluciones independentistas de América Latina. Biedma recrea en su Atlas Histórico cómo la creación del Virreinato establece nuevas circunscripciones - entre las que se encontraban la de Buenos Aires y la Patagonia - que remediaban la falta de vínculos duraderos entre los pueblos diseminados en vastos territorios ${ }^{215}$.

4. La Ilustración aparece — para algunos autores - como nuevas formas reguladoras de control social, que puede ser sintetizado en lo que Thomas Popkewitz llama «currículo oculto» ${ }^{216}$. Cabe decir que el conocimiento de la historia de la escolarización nos permite ver los intereses y la construcción del poder que privilegian las clases altas y medias por encima de los estratos sociales postergados desde lo económico, étnico o de género. La nueva educación plantea la desigualdad del acceso a la misma por parte de determinados estratos sociales de americanos. En el Río de la Plata, el testimonio de Manuel Moreno, al referirse a la educación de su hermano Mariano, es elocuente al respecto:

América Española durante los siglos XVI, XVIII y XVIII, Introducción Horacio Ramos Mejía, Cultura Argentina, Buenos Aires, 1917, pág. 288.

${ }^{213}$ Siebzehner, B. B. La Universidad americana y la Ilustración, Madrid: Mapfre, 1994, pág. 131.

${ }^{214}$ Kant, E. «Que es la ilustración?» 1784, en: Filosofia de la Historia, Buenos Aires: Fondo de Cultura Económica, 1941, págs. 25-65.

${ }^{215}$ Biedma, J. J. Atlas histórico de la República Argentina, Buenos Aires: Angel Estrada y Cia., 190, .pág. IX.

${ }^{216}$ Popkewitz, T. S. «Historia, el problema del conocimiento y la nueva historia», ob.cit., págs. 15-58. 
Ocho años había gastado el doctor Moreno en los estudios y por consiguiente se hallaba entonces a los 20 años de edad. Aquí crecieron las dificultades de mi padre para proporcionarle la carrera, pues cualquiera que se eligiese requería mucho más dinero del que él podía suministrar ${ }^{217}$.

En el Río de la Plata - como ha sido ampliamente estudiado - Mariano Moreno fue la figura más representativa de su difusión a través de la traducción del Contrato Social del pensador Jacobo Rousseau $^{218}$. Pero en su obra puede observarse una orientación dual en cuanto si bien aceptaba las ideas de Rousseau sobre la constitución de un nuevo orden, se manifiesta enemigo del secularismo del francés. El derecho natural sobre la libertad de expresión era para él la verdadera puerta para una plena participación política. Aunque, tal como ilustra Noemí Goldman, «la educación política del pueblo» es el centro de la concepción revolucionaria de Moreno. La instrucción de los pueblos despertará la voluntad de la independencia. Conferir al pueblo medios racionales para que puedan ejercer sus propios derechos ${ }^{219}$. Esta autora —en su análisis de la voluntad colectiva y educación política del pueblo - reafirma la necesidad del rol de los «ilustrados» como fuente de experiencias prácticas. La Junta, que integró Moreno, y por la indudable influencia de el Secretario de la misma propone una reforma intelectual que trascienden en obras como la Biblioteca Pública, la creación de la Academia de Música, la mejora de la calidad de la enseñanza de las escuelas públicas y la libertad de pensamiento para el desarrollo de «conocimientos útiles»y de las «luces», traducido en el artículo «Sobre la libertad de escribir» publicado en la Gazeta ${ }^{220}$. Escapa al objetivo de esta tesis ahondar más en la figura de Moreno, quedando por tanto trunco un análisis más sobre su obra en la educación rioplatense que se extendió a todos los ámbitos: creación de una Biblioteca y de una Academia de Música.

217 Moreno, M. «Vida y memorias del Dr. Dn. Mariano Moreno», en: Biblioteca de Mayo, Tomo II, Autobiografías, Cámara de Senadores, Buenos Aires, 1960, pág. 1156.

${ }^{218}$ Nota: Mariano Moreno (1778-1811) se formó en el Colegio de San Carlos de Buenos Aires donde conoció el trasfondo ideológico y cultural hispánico durante su instrucción. Las doctrinas de Suárez y literatura europea que conoce por canales ilegales, fueron cimiento para su posterior carrera en la Universidad de Chuquisaca donde realiza estudios doctorales. Nombramos solo algunos de los tantos autores que han profundizado su figura así como las fuentes documentales imprescindibles para su estudio: Levene, R. Ensayo histórico sobre la Revolución de Mayo y Mariano Moreno, Tomos I, II, y III, Buenos Aires: Edit. Cientifica Literaria, 1925; Levene, R. Ideas políticas y sociales de Mariano Moreno, Buenos Aires: Emece, 1948; Gandía, E. de. Las ideas políticas de la independencia americana, Buenos Aires: De palma, 1968. Gandía, E. de Mariano Moreno: los problemas políticos de su biografia y de los orígenes de Mayo, Bahía Blanca, Universidad Nacional del Sur, 1964. Bagú, S. Mariano Moreno: pasión y vida del hombre de Mayo, Buenos Aires: Claridad, 1939. Puiggrós, R. Mariano Moreno y la Revolución democrática argentina, Buenos Aires: Problemas, 1941. Moreno, M. Plan de operaciones, Prólogo de Esteban de Gori, estudios críticos de Norberto Piñeiro y Paul Groussac, Buenos Aires, Biblioteca Nacional, 2008. Moreno, M. Escritos, Prologo y edición Ricardo Levene, Buenos Aires: Estrada, 1943. Moreno, M. Escritos judiciales y papeles políticos, Prólogo de Ernesto Fitte, Buenos Aires, ANH, 1964.

${ }^{219}$ Cfr. Goldman, N. El discurso como objeto de la historia. El discurso político de Mariano Moreno, Buenos Aires: Hachette, 1995, págs. 147-157.

${ }^{220}$ Gaceta de Buenos Aires, jueves 21 de junio de 1810, página 59. Citado por Goldman, ob.cit. pág.141. 
Fernando Barba sostiene que existió en Moreno y en los dirigentes revolucionarios, no solo una revolución de ideas sino la idea de concretarlas. Pero, los avatares políticos hicieron difícil su resolución, fuera de las expresiones y proclamas a favor de la educación pública. No obstante, la educación pública estaba apoyada desde mayo de 1810 en las estructuras institucionales de Cabildos y Gobernadores intendentes. Recién en 1816, existió una mirada puesta más en los contenidos de la educación que en los intentos reglamentarios que concebían a la escuela como un lugar de corrección de discípulos. En lo concerniente a las escuelas de campaña el autor rescata el primer Reglamento redactado por Rufino Sánchez y Francisco Javier Argerich de cuyos capítulos son dignos de destacar aquellos que establecían la obligatoriedad escolar, evitar conductas violentas de los preceptores o maestros con los niños y el control sobre la conducta del docente ${ }^{221}$.Culminamos este breve análisis de su figura en su retórica de la escolarización que afirmaba los nobles mitos de la Ilustración y de la interpretación del mundo.

5. El saber experto, en el caso específico de la campaña rioplatense, estaría puesto en la educación de curas y maestros quienes aprendiendo a leer permitiría el acceso a la comprensión de un periódico en sus curatos o parroquias como técnica reguladora de una sociedad. Propuesta de indudable similitud a la de Gaspar de Jovellanos en su Reforma Agraria. Bajo la perspectiva gramsciana, los lectores se convertirían en elementos ideológicos transformadores desde el punto de vista filosófico, maleables a cualquier transformación e incitativos a a cambios económicos ${ }^{222}$. En nuestra campaña bonaerense y tal como lo demuestra María Elena Barral hacia fines del siglo XVIII los párrocos eran la única autoridad de poder institucional de la gente de campo, configurándose en la época borbónica la dupla cura-alcalde. Los párrocos eran los capellanes de las cofradías que se fueron erigiendo en los nuevos centros urbanos. Entre sus funciones tenían establecidas las de la educación elemental, la integración de juntas protectoras de escuelas y nuevas formas de difusión escritas ${ }^{223}$ Pero es el protagonismo que tendrá específicamente Manuel De la Hoz en Carmen de Patagones hacia 1815, en las que se observaban las abundantes referencias propias del pensamiento Ilustrado, sobre «las conductas ociosas y dadas al juego».

También Carlos María Gorla se detiene en la función educadora de los curas de Patagones. Transcribe la orden del superintendente del Río Negro acerca de las facultades que le cabían a los padres capellanes, quienes en «calidad de curas párrocos» debían informar sobre el ejercicio de

${ }^{221}$ Barba, F. E. «Los primeros reglamentos de educación primaria de Buenos Aires. 1816-1818», en: Temas de de Historia Argentina II, Instituto de Historia Argentina «Ricardo Levene», La Plata. Universidad Nacional de la Plata, Facultad de Humanidades y Ciencias de la Educación, 1997, págs. 7-16.

${ }^{222}$ Gramsci, A. ob.cit., pág. 150.

${ }^{223}$ Barral, M. E. «De mediadores componedores a intermediarios banderizos: el clero rural de Buenos Aires y la paz común en las primeras décadas del siglo XIX», Anuario IEHS, n. ${ }^{\circ}$ 23, Universidad Nacional del Centro de la provincia de Buenos Aires, Tandil, 2008, págs. 151-174. 
maestro de escuela, a la que consideraba «principal obligación de enseñar doctrina cristiana y buenas costumbres a la juventud» ${ }^{224}$.

La campaña bonaerense de principios del siglo XIX había comenzado a tener cambios políticos y culturales propios de cambios ideológicos y reformistas de los primeros gobiernos criollos. El cura-párroco era un ariete que cumplía la función de control de «la vagancia y vigilancia de la moral pública». Jovellanos había visto que si bien el poder económico del clero español provenía de la posesión de la tierra por parte del clero español que se mantiene inculta como su pueblo, se debe procurar que la promoción de la observación y la valoración de la ciencias exactas, pudieran realizarse a través de cartillas técnicas para educar al labrador. «En estilo llano y acomodado para la comprensión de un labriego», podrán los párrocos difundir cartillas técnicas para mejorar sus $\operatorname{cosechas}^{225}$.

6. Por último, pusimos el acento en el pensamiento ilustrado español del siglo XVIII que favoreció la confianza en la razón, la explicación racional del universo, la fe en el hombre y en sus capacidades, acompañados por un optimismo ilimitado en el progreso. Nos detuvimos en la lectura de las obras escritas por Feijóo, Jovellanos y Campomanes, encontrando que ellas habrían tenido una incidencia mayor sobre otros pensadores europeos, en especial en los actores de la fundación de la ciudad del Carmen, de quienes hicieron el reconocimiento de las costas del Atlántico y la expansión fronteriza analizada con anterioridad a la fundación de Bahía Blanca. Llegamos a esta conclusión teniendo en cuenta que quienes dirigían estas empresas, algunos pobladores más ilustrados o quienes cumplían funciones como empleados de la Corona, y posteriormente de los primeros gobiernos criollos, habían sido educados en la España del siglo de la Luces, en centros educacionales donde ya se leían con avidez nuevas teorías filosóficas. El padre benedictino Jerónimo Feijóo y Montenegro plasmó un nuevo discurso en lo social y político desde la Universidad de Oviedo. La introducción de estas nuevas teorías había marcado una división entre los españoles, entre quienes las rechazaban o las aceptaban. Frente a ello, Feijóo toma una posición:

Dos extremos, entreambos reprehensibles, nota en nuestros españoles, en orden de las cosas nacionales: unos las engrandecen hasta el cielo; otras las abaten hasta el abismo. De aquí aquel bárbaro desdén con que miran a las demás naciones, asquean su idioma, abominan sus costumbres, no quieren escuchar, o escuchan con irision, sus adelantamientos en las artes y las ciencias $^{226}$.

Criticó con vehemencia la enseñanza memorística y verbalista de los seminarios y conventos, que repetían conocimientos y verdades que nadie atrevía a discutir: «Hay unos sabios no de entendimiento

${ }^{224}$ Gorla, C. M. «Establecimientos españoles en la Patagonia: estudio institucional», Prologo del Dr. Luis Navarro García, Escuela de Estudios Hispano-Americanos de Sevilla, CCCV, Sevilla, 1984, págs. 223-252.

${ }^{225}$ Jovellanos, G. «Informe sobre la ley agraria», en: Obras escogidas, Tomo I, Madrid: Rivadeneyra, pág. 198.

${ }^{226}$ Feijóo y Montenegro, B. J. Obras escogidas, Biblioteca de Autores Españoles, Madrid, 1952, pág. 45. 
sino de memoria en quienes están estampadas las letras como las inscripciones en los mármoles...». Y en clara alusión a los profesores universitarios sostenía que «...si hubiera dos tiendas, de las cuales en las que se vendiera memoria y en la otra entendimiento, el dueño de la primera se haría riquísimo, y el segundo moriría de hambre» ${ }^{227}$.

Trató de dar a conocer a Descartes, Newton y Bacon, aunque en su obra se refleja las antinomias de educación e ignorancia, dinamismo y pereza intelectual, innovación y falta de curiosidad ${ }^{228}$. La enseñanza elemental se impartía en España y en sus colonias, a fines del siglo XVIII, en casas particulares, iglesias, conventos y en algunas escuelas públicas donde unos pocos accedían a la educación. Grupos de españoles plantean la necesidad de la educación como derecho natural, sin diferencia de castas y clases. Tribuna de estos reclamos fue la prensa española en donde se debatieron diferentes proyectos, muchos de ellos dispares en métodos, pero muestra clara de un creciente interés por las cuestiones de la enseñanza ${ }^{229}$.

En Feijóo se conjugó el desorden barroco con la rigurosa disciplina racional del cartesianismo. La razón y el sentido utilitarista toman, en este autor, una vital fortaleza orientadora hacia acciones concretas. Esa extrema valorización de la razón debía conciliar «con dogmas y preceptos religiosos a los que la razón no puede llegar» ${ }^{230}$.

La lectura a la que hemos hecho referencia anteriormente sobre las expediciones de los hermanos Viedma, como las de García y Undiano Gastelu, demostrarían la existencia no solo de una misión de ocupación territorial o de política de expansión fronteriza sino de un cambio en el pensamiento de esos españoles. Quienes no solo demuestran su preocupación en la instalación de nuevos puertos en la costa patagónica, sino que realizan estudios científicos de la fauna, flora y nuevas culturas. Sus descripciones - acompañadas de croquis, mapas y dibujos - nos muestran un hombre nuevo. Otorga un nuevo valor a los objetos conquistados, donde se reconoce un modelo teórico adquirido que puede ser trasladado a realidades muy diferentes. La presencia de hombres de ciencia (cirujanos y sangradores) como de hombres que tengan conocimientos técnicos, se traducirían como bien lo indica Barba, en mejores salarios para quienes tuvieran otros méritos y virtudes y un verdadero impulso hacia la agricultura ${ }^{231}$. También para estos viajeros, como para los pensadores españoles, existe una preocupación por el destierro del «ocio», axioma que será usado por Campomanes y Jovellanos. Por acto reflejo en el Río de la Plata en periódicos como el Semanario de Agricultura de Vieytes, el Telégrafo Mercantil y en las

${ }^{227}$ Ibidem, págs. 80-81.

${ }^{228}$ Cfr. Caramanes, O. F. «El padre Feijóo en la realidad española», en: Fray Benito Jerónimo Feijoo y Montenegro, La Plata, Universidad Nacional de la Plata, 1964.

${ }^{229}$ Sarrailh, J. La España ilustrada de la segunda mitad del siglo XVIII, 1a edición, Buenos Aires: Fondo de Cultura Económica, 1957, pág. 214.

${ }^{230}$ Feijóo y Montenegro, B. J. Discursos y cartas, Biblioteca Clásica Ebro, Clásicos Españoles, Barcelona: [s/e], 1943. pág. 11.

${ }^{231}$ Barba, F. «Pobladores y Empleados en Carmen de Patagones», op. cit. pág. 148. Jovellanos había sostenido que la riqueza territorial no debía ser transmisible sólo por nacimiento. Había que dar valor al mérito del individuo como máxima general de la legislación. Jovellanos, «Informe sobre la ley agraria», op. cit. pág. 175. 
Memorias Consulares de Manuel Belgrano, traducen en su visión utilitarista cómo el ocio es sinónimo de holganza. ¿Quiénes son los ociosos? Dentro de este marco quedan comprendidos aquellos que no participaban en actividades que producían un fruto material o estaban enquistados en el aparato burocrático español. Esta burocracia que según Feijóo estaba conformada por escribanos, oficiales de justicia, procuradores, notarios y ministriles, tachados como «gente inútil» que «teje enredos, vierte chismes, mueve pleitos, sugiere trampas» ${ }^{232}$. Pretendió con sus obras corregir la forma de concepción del trabajo de la tierra como salida o remedio para uno de los males de la sociedad española: «Quien limpiase la tierra de ociosos haría un gran servicio, no sólo a la tierra, más aún al cielo» ${ }^{233}$.

Rodríguez de Campomanes, no tan moderado como Jovellanos, fustigó el carácter parasitario de la Iglesia, al atribuirle que «todos los vicios del siglo han entrado en ella» ${ }^{234}$. Perteneció al grupo de los «manteístas», grupo universitario de menores recursos que remplazará progresivamente en la Corte de Carlos III a los «colegiales», estudiantes de estamentos sociales privilegiados. En este último grupo se encontraba Jovellanos. La capacidad y aptitud intelectual de Campomanes favoreció su ascendente carrera en la Universidad de Sevilla. Allí realizó los primeros trabajos de Derecho alternándolos con estudios de la lengua árabe que le permitió leer obras sobre prácticas agrícolas y avances científicos que estos realizaban en sus tierras. Realizó traducciones del griego mostrando su afición por la historia como ciencia, en contraposición al escepticismo que sobre esta disciplina había manifestado Feijóo. No ocultó la lectura crítica de obras de Ustáriz (Teórica y práctica del Comercio de España, 1724) y Ulloa (Restablecimiento del Comercio y fábricas de España, 1740) y de Montesquieu (El Espíritu de las Leyes). Estas lecturas implicaron una toma de posición ideológica en su discurso económico y educativo. A partir de su obra Discurso crítico politico del Estado de Literatura de España y medios para mejorar las Universidades, construye lo que Dubois llamó «el universo del discurso», es decir la totalidad de los enunciados de la Ilustración española: confianza en la razón, explicación racional del universo, fe en el hombre y sus capacidades naturales y optimismo ilimitado en el progreso humano. Todos estos principios pueden ser resumidos de la siguiente manera:

$>$ Rehabilitar la agricultura y la industria manufacturera, liberando el prejuicio que consideraba denigrante a este oficio.

Conocer la «ciencia económica» a fin de lograr el aumento de la riqueza nacional. «La riqueza del pueblo es la base fundamental de la riqueza del estado, siendo cosa cierta que ningún Estado será rico cuyo pueblo sea pobre» ${ }^{235}$.

${ }^{232}$ Feijoo y Montenegro, B. «La ociosidad desterrada y la milicia socorrida», en: Obras Escogidas, Biblioteca de Autores Españoles, Madrid: Atlas, 1952, págs. 468-469.

${ }^{233}$ Idem, pág. 469.

${ }^{234}$ Campomanes, G. M. «Discurso a los seminaristas», en: Documentos del archivo de Campomanes, Madrid: FUE, 1974, pág. 107.

${ }^{235}$ Campomanes, G. M. Colección de obligaciones fiscales del Excmo.Señor Conde de Campomanes, Madrid: Edición J. Alonso, 1841-43-, Tomo III, pág. 118. 
Propone el aumento de la productividad y de la población, que a su vez producirá aumento de la productividad y del consumo. Para lograr su incremento era necesario formar y educar el artesanado y a los labradores, en especial en hábitos de trabajo.

$>$ Con el fin de eliminar al «vago y mendigo», a quienes considera «plaga nacional», redacta un plan que los incorporaría a la sociedad a través de oficios ${ }^{236}$.

> Consideró a las Sociedades Económicas como un instrumento esencial de difusión técnica y científica de métodos de labranza.

A partir de 1780 Gaspar Melchor de Jovellanos jugó un papel destacado en la corte de Carlos III, influenciado por las lecturas de la obra de Rousseau. Reconoce que la observación y la experimentación son las primeras fuentes del conocimiento humano. Por ende, todas las verdades teóricas se construyen por medio de ambas. Defiende la instrucción pública y gratuita y aboga para que este beneficio se extienda a la mayor cantidad de ciudadanos. Acentúa la legitimidad de las familias pobres o ricas de ser instruidas «porque la (instrucción) es un medio de adelantamiento, de perfección y felicidad...» ${ }^{237}$. Nótese aquí como la instrucción pública es considerada como un derecho inherente a todos los individuos, como una forma de perfectibilidad de la naturaleza humana y el desenvolvimiento de sus facultades físicas e intelectuales. En la cuarta cuestión de su Memoria considera que corresponde confiar el desarrollo de las primeras a la educación doméstica y las segundas a las instituciones previstas por el Estado. Para finalizar elabora un plan completo de enseñanza secundaria donde presta especial atención al estudio de la lengua, la lectura de los clásicos, del latín y de lenguas modernas. Los estudios de filosofía estarían divididos en lógica y ética, como instrumentos de preparación del ciudadano en su relación con el Estado y la sociedad.

Las obras de estos pensadores españoles fueron legitimadas en los escritos de la prensa rioplatense - como dijimos anteriormente- como forma de divulgación de sus principios. El Semanario de Agricultura, Comercio e Industria de Hipólito Vieytes, el Telégrafo Mercantil de Francisco Cabello y Mesa y el Correo de Comercio de Manuel Belgrano. Este último en innumerables artículos — que escaparía su enumeración a la temática - comparte la postura de Jovellanos en priorizar la educación del labrador. La misma debe ser comprendida dentro de un proyecto económico integral, donde la educación no solo permitirá mejorar el nivel de vida sino será un instrumento para lograr mayores recursos ${ }^{238}$.

Con una acendrada concepción utilitaria como forma de conocimiento del mundo y de obtener beneficios económicos y sociales, tanto Hipólito Vieytes, Manuel Belgrano y Mariano Moreno, fomentaron a través de los periódicos, gacetillas e instituciones, un creciente interés por la experimentación y racionalización como fundamentos epistemológicos, alejándose de los saberes religiosos y mágicos ${ }^{239}$. Podemos suponer con Chartier, que la práctica de la lectura oralizada o buscada

\footnotetext{
${ }^{236}$ Rodríguez Díaz, L. Reforma e ilustración en la España del siglo XVIII, Madrid: FUE, 1975, pág. 216.

${ }^{237}$ Jovellanos, G. M. Obras escogidas, Tomo I, Madrid: Rivadeneyra, 1958, pág. 231.

${ }^{238}$ Correo de Comercio, Academia Nacional de la Historia, Buenos Aires, 23 de junio de 1810.

${ }^{239}$ Desde el Consulado de comercio creado el 2 de junio de 1794, Belgrano propuso en la primer memoria (1796) la creación de una Escuela de Náutica (1799) y de la Academia de Geometría y Dibujo (1799). Además proyectó sin que se concretaran la creación de una Escuela de Comercio, escuelas agrícolas y de la enseñanza primaria,
} 
por los textos, creará en los hombres que poco a poco habitan la campaña bonaerese, un público de lectores populares que abarcará tanto a los mal alfabetizados como a los analfabetos, que gracias a la voz lectora se familiarizarán con las obras y géneros de la literatura culta, lejos de los medios letrados ${ }^{240}$.

\subsection{Alternativas educacionales en el período de transición: de la propuesta rivadaviana a la rosista (1821-1852)}

Como una primera aproximación en el abordaje de problema educativo en la provincia de Buenos Aires resulta necesario demarcar dos momentos que indicarían visiones y actitudes colectivas que se convierten en prácticas educativas diferentes.

En el primero de ellas resulta imprescindible la determinación de aquellas prácticas educativas que hicieron que los «intelectuales» de la etapa rivadaviana (1821-1827) plasmaran un modelo de marcado tinte diferencial con el rosista.

Siguiendo una concepción gramsciana, y en lo que respecta a la organización escolar en este contexto demostraría la importancia que alcanzan las categorías y las funciones intelectuales de determinantes actores sociales. En la medida en que se pretende extender la «intelectualidad» de cada individuo, se tiende a generar mayores especializaciones y a perfeccionarlas. Estos intelectuales de carácter urbano crecen desarrollando actividades económicas y políticas vinculadas a instituciones de mayor complejidad dentro de un marco de modernización estatal. Las diferentes instituciones que surgen en la denominada «época rivadaviana», vinculadas a una organización económico-comercial más compleja, desarrollan operaciones novedosas en lo que respecta al crédito público, a la legislación de tierras, al régimen tributario y bursátil, y a las inversiones, especialmente las británicas ${ }^{241}$.

gratuita y obligatoria para todo el virreinato. Su ideario fue difundido a través del Telégrafo Mercantil de Cabello y Mesa y del Semanario de Agricultura, Comercio e Industria de Hipólito Vieytes. Sobre este último, he realizado un exhaustivo análisis en un trabajo inédito, «Vieytes: propuestas educativas para un cambio estructural de la economía rioplatense de principios del siglo XIX», que fuera presentado en el Congreso Nacional de la Sociedad Argentina de Historiadores de la Asociación de Clubes Argentinos de Servicio, "Historia de la industria en América», auspiciado por la municipalidad de Avellaneda, en la provincia de Buenos Aires, los días 26, 27 y 28 de junio de 1987. Felix Weinberg, en Antecedes económicos de la Revolución de Mayo. Escritos publicados en el Semanario de agricultura, industria y comercio (1802-1806), Buenos Aires: Raigal, 1956, puntualiza tomando las palabras de José Enrique Rodó, que Vieytes fue «propagandista de ideas útiles, escritor de economía política, el más experto y práctico de cuantos escribieron sobre esta materia».

${ }^{240}$ Chartier, R. Sociedad y escritura. La cultura como apropiación, México: Instituto Mora, 1995, págs. 148-49.

${ }^{241}$ En los diferentes estudios historiográficos correspondientes al período de preeminencia política de Bernardino Rivadavia, se analizan con profundidad aquellas medidas que un grupo político propicia una acción renovadora en todos los sectores que cuentan «con la adhesión de las clases altas urbanas». Cfr. Bagú, S. El plan económico del grupo rivadaviano (1811-1827). Su sentido y contradicciones. Sus proyectos sociales, Facultad de Filosofía y Letras. Universidad Nacional del Litoral, Rosario, 1966. Barba, E. M. «Orígenes y crisis del federalismo argentino», Revista de historia, n. ${ }^{\circ}$ 2, Buenos Aires, $2^{\circ}$ trimestre, 1957, pág. 3. Barba F. Frontera ganadera y 
La propuesta del grupo rivadaviano, tendió fundamentalmente a la modernización en el orden económico y social, y para concretarla estuvo marcada con una serie ininterrumpida de decretos y bandos en materia económica, política, social y educacional.

Rivadavia, ya sea como ministro de gobierno de Martín Rodríguez o como presidente generará las condiciones suficientes para la sistematización escolar partiendo de la convicción que es el Estado quien debe generar acciones que permitan la universalización educativa. Es evidente que, tal como es analizado por Barthes en Mitologías el problema del conocimiento y del saber, están indefectiblemente unidos al poder, por lo que el saber es uno de los mitos burgueses de la modernidad ${ }^{242}$. Seguramente, y siguiendo conceptualmente este autor, Rivadavia se ubica como «productor del mito» pero a su vez en realizador del mismo, responsable de su desarrollo, en un ámbito social determinado. Y en la medida que los sujetos maduran tal mito, el concepto que la educación es fuente indispensable para acceder al poder, permite hegemonizar a las pequeñas burguesías urbanas. Coincidente con ello, Rivadavia perfila innovaciones en los circuitos educativos a partir de 1821, con la introducción del sistema Lancasteriano, la fundación de la Universidad de Buenos Aires y la creación y el fortalecimiento de un Departamento de Primeras Letras con la figura del Doctor Segurola.

Otro factor de vital importancia para el sostenimiento de esta nueva estructura educativa es la manifestación pública de compromiso en la injerencia estatal en las producciones culturales de la época: «...que la ilustración pública, sin cuyo auxilio toda mejorasería (sic) transitoria, había ocupado los

guerra contra el indio. La frontera y la ocupación ganadera entre los siglos XVIII y XIX, Universidad Nacional de la Plata, La Plata, 1995. Halperin Donghi, T. Argentina. De la Revolución de la Independencia a la Confederación rosista, Buenos Aires: Paidos, 1972. Piccirili, R. Rivadavia y su tiempo, Buenos Aires: Peuser, 1953. Ubeira, A. M. Presidencia de Rivadavia. Politica nacional: su repercusión en las provincias, Buenos Aires: [s/e], 1984. Ternavasio, M. «Las reformas rivadavianas en Buenos Aires y el Congreso General Constituyente (1820-27)», en: Goldman, N. Historia Argentina. Revolución, República y Confederación. (18061852), Buenos Aires: Sudamericana, 1998. Ternavasio, M. «La visibilidad del consenso. Representaciones en torno al sufragio en la primera mitad del siglo XIX», en: Sábato H. y Lettieri, A. (comps.). La vida política en la Argentina del siglo XIX. Armas, votos y voces, Buenos Aires: Fondo de Cultura Americana, 2003, págs. 57-73. Myers, J. «Las paradojas de la opinión. El discurso político rivadaviano y sus dos polos: "el gobierno de las luces" y "la opinión pública, reina del mundo"», en: La vida política en la Argentina del siglo XIX. Armas, votos $y$ voces, Buenos Aires: Fondo de Cultura Económica, 2003, págs. 75-95. Romero, L. A. La feliz experiencia (1820-1824), Buenos Aires: La Bastilla, 1976. Cansanello, C. «Domiciliados y transeúntes en el proceso de formación estatal bonaerense (1820-1832)», Entrepasados, año IV, n. ${ }^{\circ}$ 6, 1994. Fradkin, R. O. (comp.). El poder y la vara. Estudios sobre la justicia y la construcción del Estado en el Buenos Aires rural.(1780-1830), Buenos Aires: Prometeo, 2007.Garavaglia, J. C. y Gautreau, P. (edits.) Mensurar la tierra, controlar el territorio. América Latina, siglo XVIII-XIX, Rosario: Protohistoria, 2011. Solo nombramos algunos de los estudios más tradicionales.

${ }^{242}$ Barthes, R. Mitologías, México: Siglo XXI, 1985. En otra obra de este autor, El grado cero de la escritura. Bogotá: Siglo XXI, 1992, pág. 28, «las escrituras políticas están encargadas de unir con un solo trazo la realidad de los actos con la idealidad de los fines». «El poder siempre acaba de instituir una escritura axiológica...donde la palabra se hace excusa, es decir casi una justificación». 
cuidados del Gobierno» (sic)y recibido un rapido impulso conlaerección (sic) devarias (sic) sociedades literarias...» ${ }^{243}$.

Se piensa sobre la posibilidad de sancionar una ley que «ordene las bases de la enseñanza pública y que diera una mejor forma a la organización estatal de los organismos que respondieran a ella» ${ }^{244}$. Se bosqueja un proyecto abarcativo de todos los niveles de enseñanza, bajo las condiciones que ella sea «pública, uniforme y gratuita». Se dividiría en primeras letras, segundas letras o «ciencias generales» y tercera o ciencias especiales. Pero era la enseñanza de primeras letras la merecedora de mayor consideración por parte del Estado que establecía algunos principios que permitían entender a la buena educación no solo a través del logro de las prácticas de la lectoescritura, sino de la formación patriótica, moral y de sus derechos como miembros de una sociedad «libre y organizada» ${ }^{245}$. El periodismo prorivadaviano - al igual que en el período anterior - se convierte en herramienta de difusión sobre las bondades del sostenimiento estatal de la educación, vinculando el proceso de independencia americana con la fe iluminista en el saber cómo condición de la felicidad y el progreso del pueblo. El Centinela, al comunicar la introducción del sistema Lancaster, dirá:

\footnotetext{
$\mathrm{Al}$ arrojar la América las cadenas que la tenian estacionada no ha olvidado que nada se avanza en esta glorisosa carrera, si la antorcha de la ilustración no ilumina hasta los lugares más (sic) reconditos de su vasta extensión ${ }^{246}$.
}

Ideológicamente, esta etapa (1821-1827) ha sido definida por Myers como «el momento Rivadavia», cabe decir, el momento en el cual las principales tradiciones ideológicas que han configurado los vocabularios políticos del siglo $\mathrm{XX}$, como el liberalismo en sus diversas variantes, los socialismos y conservadorismo, «aun no habían alcanzado una plena cristalización» ${ }^{247}$. El autor observa sobre la supuesta contradicción que existía en el lenguaje político y argumentación teórica de la época y su praxis gubernamental, observación que realiza en torno a la reforma eclesiástica y la actuación parlamentaria del llamado «grupo rivadaviano». Considera que este grupo aplicó para la transformación cultural de la época, la lógica de la política de círculo o facción. Utiliza el principio de Raymond Williams para los hombres cercanos a instituciones formales, con reproducción de presupuestos, actitudes y creencias con ciertas reminiscencias del ideal reformista borbónico y una ideología explícitamente republicana.

${ }^{243}$ Provincia de Buenos Aires. Acuerdos de la honorable cámara de Representantes. Año 1822, 1 de mayo de 1822, La Plata, 1981, pág. 14.

${ }^{244}$ Ibidem.

245 «La Abeja Argentina», 15 de julio de 1822, Senado de la Nación, Biblioteca de Mayo. Colección de Obras y Documentos para la Historia Argentina, Tomo IV, Buenos Aires, 1960, pág. 5345.

246 «El Centinela», n. ${ }^{\circ}$ 40, 1 de mayo de 1823, Biblioteca de Mayo, Buenos Aires, Senado de la Nación, 1960, Tomo IX, Periodismo, Segunda parte, pág. 8578.

${ }^{247}$ Myers, J. Op. cit., págs. 75-77. 
Para Francisco Romero el pasaje de Rivadavia por el Colegio de San Carlos no dejó una huella profunda: «en lo esencial — dice el autor - fue un autodidacta», recordando con afecto a uno de sus profesores el presbítero Pedro Fernández. A pesar de carecer de una formación universitaria fue influido por la obra de Raynal y la lectura de economistas españoles como Jovellanos. Demostró —para este pensador- que en lo político y social, las realizaciones estaban a la zaga de las ideas. También aprecia que la Ilustración tuvo una significativa importancia en su pensamiento, superando con la acción los aciertos de una época.

Sorprende en Rivadavia la coincidencia del utopista con el realizador; del pensador político que
se adelanta con mucho a su tiempo y su medio, con el estadista práctico que organiza y
construye $^{248}$.

Diego Pró asegura que los hombres que acompañaron en el gobierno a Rivadavia constituyen la segunda generación argentina teñida por las ideas iluministas, bajo la forma de lo que se denominó Ideología Francesa, que puede considerarse una derivación de la filosofía de las luces. En la transmisión de estas ideas filosóficas y la enseñanza distinguimos figuras como Crisóstomo Lafinur, Manuel Fernández de Agüero y Diego Alcorta. La praxis política la ideología estaba representada por Juan Cruz Varela, Valentín Alsina, el general Lavalle y Florencio Varela. Estos hombres anhelaron dar una respuesta concreta a la cuestión del «para qué» de la revolución de Mayo, buscando en las reformas la respuesta al pensamiento de Juan Jacobo Rousseau y Jeremias Bentham ${ }^{249}$.

En todo proceso histórico la filosofía introduce conceptos teleológicos que permiten extraer imperativos de orientación normativa en las prácticas políticas, sociales y hasta las cotidianas de vida. Al igual que los principios filosóficos de los autores señalados, existe una fundamentación que se contextualiza en las reformas educativas propuestas por Rivadavia, que en gran parte producto de la lectura de los Tratados de Legislación Civil y Penal de Bentham. Dentro de los «Usos que pueden hacerse del poder de la instrucción», el filósofo proponía la publicación de los papeles públicos como «forma de instrucción para bajar del gobierno al pueblo ó subir del pueblo al gobierno». Prestó atención a la estructura proposicional del lenguaje periodístico bajo la teoría utilitarista de la prensa de que los esquemas educativos favorecerían realizar cambios desde la apropiación de los conocimientos en el ámbito familiar - con un maestro particular — hasta la extensión a los cuadros de gobierno y sociedades de beneficencia, que atendieran la indigencia y mendicidad ${ }^{250}$.

${ }^{248}$ Francisco R. «Las ideas de Rivadavia», en Cursos y conferencias, Volumen 29, Buenos Aires: [s/e], 1946, págs. 77-87.

${ }^{249}$ Pro, D. «Periodización del pensamiento argentino», op. cit., págs. 20-22.

${ }^{250}$ Bentham, J. Tratados de legislación civil y penal, Edición preparada por Magdalena Rodríguez Gil, Madrid: Editora Nacional, 1981, págs. 395-400. Otros autores argentinos —entre ellos los mencionados- enfatizan la influencia de este pensador inglés sobre el pensamiento de Rivadavia, quien se habría convertido en Europa y en América en oráculo de su tiempo. Su teoría utilitarista habría logrado transformar como pocos la plataforma de 
La formación ideológica del «grupo rivadaviano», como lo define Bagú, buscaba a través de la traducción y publicación de los Sofismas políticos de Jeremy Bentham, en la Abeja Argentina, una forma de generalizar los conocimientos «que deben al genio y a la experiencia de las naciones grandes» ${ }^{251}$.

En una interpretación del primer sofisma sobre la autoridad, la misma quedaba reservada al «...valor de una opinión que se estima por el grado de inteligencia de la persona en cuestión. En segundo lugar por su grado de probidad». La probidad quedaba reducida al influjo que podían ejercer los intereses particulares por sobre los públicos. Según la concepción benthamiana la instrucción será más completa cuánto más haya tenido el individuo para adquirirla. Y la autoridad es aquella que provee el conocimiento profesional o científico. Vinculará ambos conceptos al entender que la autoridad deriva del poder, porque cuanto mayor es el poder político que posee el individuo, tanto más se aproxima a la autoridad profesional. Por lo tanto la inteligencia y la probidad están articuladas con el partido que ostente autoridad y poder, en el que quedan enmarcados la categoría de intelectuales orgánicos. Bentham logra tener tanto predicamento entre los hombres de la política contemporánea a Rivadavia, al lograr introducir un método cuantitativo de aplicabilidad a las ciencias sociales y moral. No concibe la diferencia entre racionalidad y práctica, siendo la primera de aplicabilidad concreta en la política social y económica. Y es en el progreso y su reforma política donde se logra la multiplicación de los bienes. No existe, por tanto, oposición entre arte y ciencia, ni entre pensamiento con la acción.

Ilustración es, para los rivadavianos, sinónimo de razón, en un enfático progreso en el concepto kantiano, que la convierte en el medio de «liberación del hombre de su culpable incapacidad». La Ilustración, por lo tanto, es «instrucción» y es garantía de la libertad y «...los derechos más sagrados peligran cuando la ignorancia tiene afianzado su dominio» ${ }^{252}$. Innumerables serían los ejemplos que podríamos enumerar en donde se observa la legitimidad que otorga al partido político dominante la «instrucción» de sus hombres. La autoridad se fortalece en tanto mayores hayan sido los medios y motivos que un individuo ha tenido para adquirirla. Pero la autoridad basada en la instrucción es la única que posee su fuerza persuasiva de legitimidad.

El saber que es poder es el que ha quitado el miedo a los hombres y los convierte en sus propios amos. El saber es lo que permite al hombre dominar la naturaleza y por ende, el desarrollo de la economía burguesa. Facilita a su vez la liberación del animismo, adoptando la vida con criterio de cálculo y utilidad. Concepto este último, que nos permitiría deducir las constantes batallas libradas contra el clero y otras de las categorías intelectuales más tradicionales como son los cuadros militares. La creciente militarización de las zonas fronterizas con el reclutamiento de vagos y mal entretenidos, ampliaba el espacio entre una oficialidad «instruida» y su tropa.

los partidos de la época. Cfr. Marí, E. La problemática del castigo. El discurso de Jeremy Bentham y Michel Foucault, Buenos Aires: Hachette, 1983, pág. 26.

251 "La Abeja Argentina», en Biblioteca de Mayo, Senado de la Nación, Tomo VI, n. ${ }^{\circ 5}, 15$ de agosto de 1822, pág. 5368.

252 "La Abeja Argentina», en Biblioteca de Mayo, Senado de la Nación, Tomo VI, n. ${ }^{\circ}$ 4, 15 de julio de 1822. 
De la herencia rivadaviana quedarán —no solo la conceptualización de instrucción e ilustración— sino las concreciones prácticas llevadas a cabo en la campaña de la provincia de Buenos Aires, espacio geográfico de nuestra atención, la Sociedad de Beneficencia, y las innumerables creaciones de escuelas. Esta última favoreció la introducción de la mujer en una sociedad excluyente a través de un organismo que le permitió introducirlas paulatinamente en el mercado laboral y evitar una ruptura drástica con el concepto que albergaba actividades que no fueran propias a la maternidad como el cuidado de hijos, enfermos, higiene, educación. La beneficencia traducía - por otra parte- el compromiso de un papel femenino que evitaba la intervención femenina en las esferas del poder político.

Es evidente que no estuvo previsto, en el momento de su creación, la indudable influencia que las mujeres que participaron de ella y tuvieron en el futuro en la definición estructural del sistema educativo durante el período rivadaviano y rosista.

Podemos como definición apuntar algunos puntos de fractura entre la evolución educativa desde los tiempos de mayo de 1810 y aquellos que comienzan a visualizarse a partir de 1821 :

La concepción del Estado como educador, o de la educación pública con significatividad dentro de los principios republicanos.

$>$ El Constitucionalismo liberal europeo tuvo fuerte incidencia sobre pensadores y políticos que convierten a la educación en una necesidad común, tanto como el requerimiento de alfabetismo en defensa del modelo republicano, vinculado a la compleja significación que adquiere el concepcto de «Ilustración del pueblo».

La mujer, en esta etapa, comienza a adquirir un papel protagónico como agente dinamizador del proceso educativo. La creación de la Sociedad de Beneficencia, el 2 de enero de 1823, constituirá el primer hito de reivindicación femenina dentro de la sociedad rioplatense. Tal como sostiene Graciela Morgade, la mujer, estas instituciones permiten hacer visible la condición femenina ${ }^{253}$.La experiencia en la educación les habría un horizonte mayor en la libertad y determinación, como sujetos de trans-formación socio-cultural. La sociedad de Beneficencia le confirió a la mujer un espacio hasta ese momento vedado, en razón de las prescripciones culturales de la época. Así lo refleja El Centinela:

Al fin se ha dado en Buenos Ayres un paso para reparar un ultrage, que ha sido de siglo en siglo la afrenta del linaje humano... Las mugeres han sido siempre la víctima del orgullo de los hombres y una superioridad insensata las ha hecho mirar como seres de una especie inferior... Las censuran de frívolas, y en lo que menos piensan es en dar solidez á su juicio, cultivando su espíritu y su corazon. Las critican de insignificantes, y no procuran darles importancia; y como

${ }^{253}$ Morgade, G. (comp.) Mujeres en la educación. Género y docencia en la Argentina 1870-1930, Buenos Aires: Miño y Dávila, 1987, pág. 14. 
que todas las instituciónes son por lo general obra de los hombres, aparece en ellas las mugeres en el punto de vista más ignomioso ${ }^{254}$.

Atendiendo que nuestro interés está focalizado en la frontera del sudoeste pampeano, otra de las variables observadas en esta etapa, es que el acento se puso en la educación elemental o primaria, se produce en la campaña bonaerense un aumento de matrícula en las escuelas públicas de la campaña ${ }^{255}$.

\begin{tabular}{|c|c|c|c|c|c|c|c|}
\hline Año & $\begin{array}{l}\mathrm{N}^{0} \text { de escuelas } \\
\text { pública central } \\
\text { y particulares } \\
\text { inmediatas en } \\
\text { Buenos Aires }\end{array}$ & $\begin{array}{c}N^{0} \text { de escuelas } \\
\text { en la Campaña } \\
\text { de Buenos } \\
\text { Aires }\end{array}$ & $\begin{array}{c}\mathrm{N}^{\mathbf{o}} \text { de } \\
\text { escuelas en } \\
\text { Patagones }\end{array}$ & $\begin{array}{c}\text { Niños que } \\
\text { asisten en } \\
\text { la campaña }\end{array}$ & $\begin{array}{l}\text { Niños que } \\
\text { asisten en } \\
\text { Patagones }\end{array}$ & $\begin{array}{c}\text { Niñas que } \\
\text { asisten en } \\
\text { la campaña }\end{array}$ & $\begin{array}{l}\text { Niñas que } \\
\text { asisten en } \\
\text { Patagones }\end{array}$ \\
\hline 1824 & 81 & 18 & 1 & 809 & 32 & 13 & 0 \\
\hline 1825 & 83 & 18 & 1 & 858 & 35 & 20 & 0 \\
\hline
\end{tabular}

Fuente: Registro Estadístico de la provincia de Buenos Aires, citado en Ramos, J. P. Op.cit., págs. 349-352.

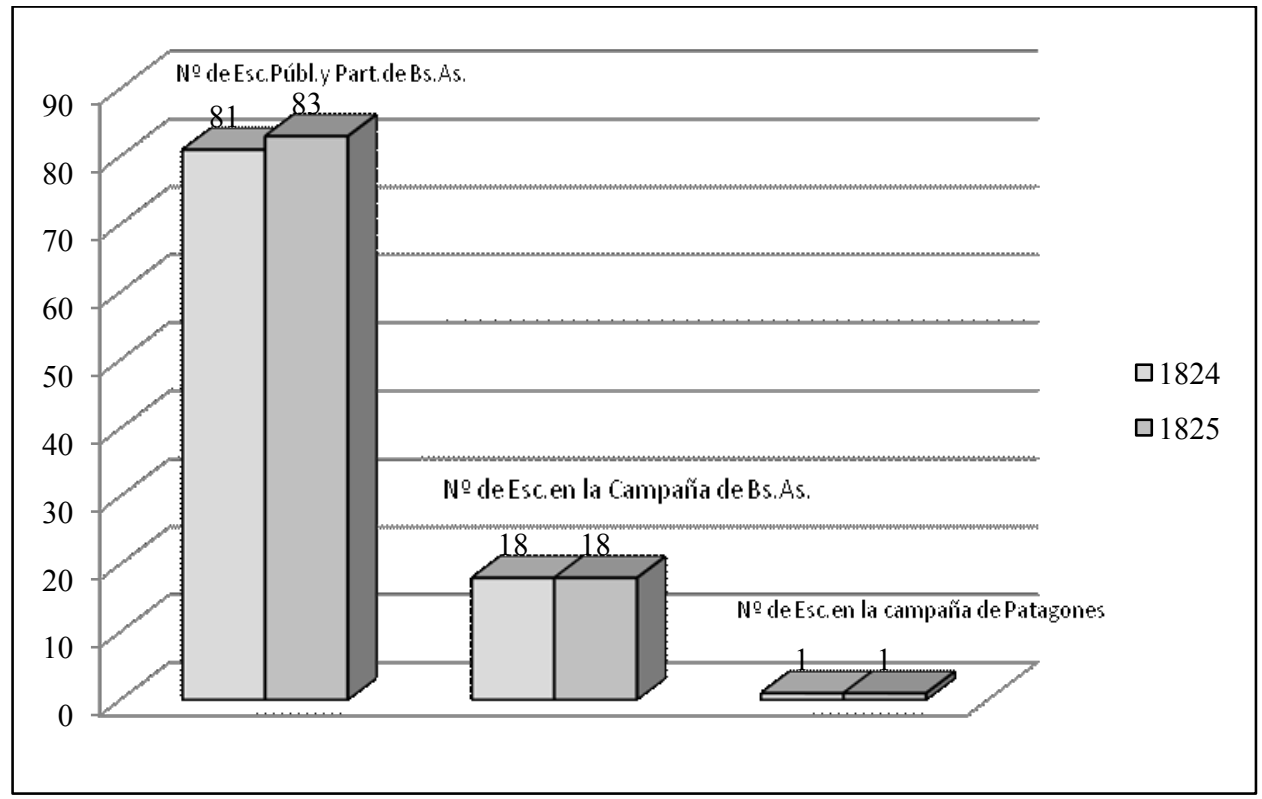

254 “El Centinela", en: Biblioteca Mayo, 2 de febrero de 1823, Colección de Obras y Documentos para la Historia Argentina, Tomo IX, 2a parte, Buenos Aires, Senado de la Nación, 1960, pág. 8637.

${ }^{255}$ Cfr. Ramos, J. P. Historia de la Instrucción Primaria, Tomo 1, Buenos Aires: Peuser, 1910, pág. 351. 

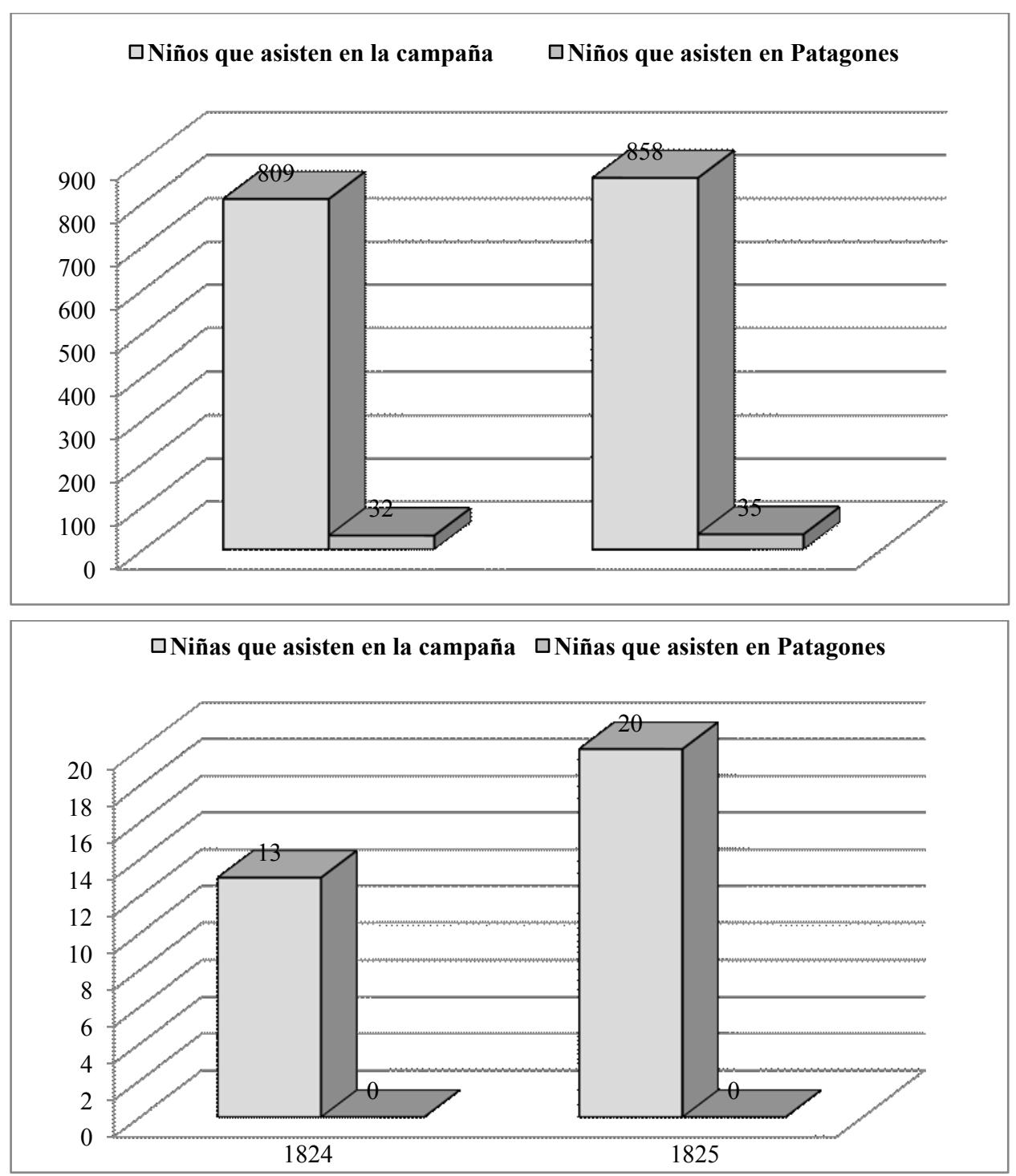

Queda evidenciada en esta estadística dos aspectos relevantes: el porcentaje de alumnos varones que asisten a la escuela pública en Carmen de Patagones es altamente satisfactorio en relación al resto de la provincia. No así la educación de la mujer relegada por muchos años hasta la aparición de las escuelas dependientes de la Sociedad de Beneficencia. Cifras que evidencia la no participación, hasta ese momento, de la mujer del sistema educativo en la campaña.

La gran obra educacional de Rivadavia ( había) llevado los rudimentos de la cultura pública -dirá Ramos- allí donde eran mas necesarios, es decir, en la vasta campaña analfabeta de la Provincia de Buenos Aires y en el seno de los hogares donde las mujeres vegetaban sin llegar á saber, siquiera, que la $\mathrm{O}$ era redonda ${ }^{256}$.

En esta etapa existió un principio ordenador: las ideas: de un propósito de escolarización se concretan e institucionalizan a través de la aplicabilidad por ejemplo del Sistema Lancasteriano, que había sido

${ }^{256}$ Idem, pág. 352. 
adoptado en Buenos Aires — según Newland - a partir de 1818, pero cuyas bondades habían comenzado a difundirse desde $1815^{257}$. En El Censor fortalecen los beneficios que tendría esta práctica, en razón de las ventajas que había tenido en las clases «infimas del pueblo» en Francia, Norteamérica e Inglaterra favoreciendo la formación de buenos artesanos. Si tomamos en este caso el conocimiento como un epifenómeno de otras fuerzas, estructuras o grupos que ejercen el control sobre las ideas, las prácticas de escolarización facilitaría como se desprende discursivamente de este periódico el control de las ideas y de las organizaciones o instituciones escolares. En la «... proporción que un país se ilumina por medio de la educación, se adelanta en prosperidad».

Si la educación es el principio del adelantamento de otras naciones, bien echará de ver el observador más superficial de nuestras instituciones políticas que ella es esencial... a la existencia de nuestro gobierno ${ }^{258}$.

Se buscaba la extensión del mismo en la Frontera. En referencia a las prácticas educativas previas a la introducción del sistema del pastor escoses James Thompson, la enseñanza se limitaba a cartillas o silabarios, con combinaciones de letras que permitirían la elaboración de breves frases y textos ${ }^{259}$. La curricula de las escuelas primarias — dirá Newland - incluía aritmética elemental y costura y bordado para las niñas ${ }^{260}$. Este cambio, a mi entender, no lo es tal, en cuanto que en la escolarización incluye una particular relación con determinados conocimientos significantes. La aritmética, las ciencias representan el universo masculino mientras que a la mujer si bien se le da protagonismo social en organizaciones educativas, la habitual frase benthamiana «conocimiento es poder», queda excluida de la práctica. El sistema lancasteriano no se limitaría — según la prensa de la época — solo a instruir. Una de las ventajas del método era «despertar y cultivar sentimientos útiles»: enseñar que era la justicia, la libertad y la beneficencia, la confianza en el orden y en la constitución según el modelo inglés y norteamericano. ${ }^{261}$

Segurola al frente de las escuelas como Inspector General de Escuelas luego de la supresión del Cabildo, fue uno de los actores principales en otorgar mayor vigor y nueva orientación centralizadora de gobierno a las escuelas: en especial en lo referente a la creación y provisión de fondos Mientras las

${ }^{257}$ Newland, C. «La educación elemental en Hispanoamérica: desde la independencia hasta la centralización de los sistemas educativos nacionales», Hispanic American Historical Review, 71:2, mayo 1991, págs. 342-345.

258 “El Censor”, en: Biblioteca de Mayo. Colección de obras y documentos para la historia Argentina, n. ${ }^{\circ} 82,9$ de abril de 1817, Tomo VIII, Buenos Aires, Senado de la Nación, 1960, Periodismo, pág. 7088-7089.

${ }^{259}$ En 1789 el Dr. Bell, eclesiástico que se hallaba en Madras empleado por el gobierno Británico, aplicó el método que lleva su nombre para educar a los hijos de los soldados que allí se encontraban. Sobre esta misma base y principios se formó por el mismo tiempo en Londres una escuela gratuita bajo la dirección de Mr. Lancaster, individuo de la sociedad de los quákeros. Información extraída del Centinela, número citado.

260 Newland, C. Buenos Aires no es pampa. La educación elemental porteña 1820-1860, Buenos Aires: CEAL,1982, pág. 61.

261 "El Censor", en: Biblioteca de Mayo, Colección de Obras y documentos para la Historia Argentina, 15 de mayo de 1817, op.cit., págs. 7074-7075. 
escuelas de la Capital pasan a depender de la reciente creada Universidad en 1822, las escuelas de campaña pasan a depender económicamente de los aportes vecinales.

Tal como lo hemos abordado anteriormente, el fuerte de Carmen de Patagones es preciso admitir que presentaba por su conformación urbana y la evolución como espacio de avance de frontera, todos los factores que lo convertirían en el primer foco de desarrollo educativo de esta región. Los mismos coadyuvaron a vincularse con cierta regularidad con Buenos Aires y por ende responder a los impulsos educativos que en esta población se generaban. Es importante tener en cuenta como el 4 de junio de 1823 se forma una Sociedad de Enseñanza en Patagones, que dio lectura al Reglamento de la Escuela de Primeras Letras bajo el sistema Lancaster ${ }^{262}$.Este aspecto demostraría que las grandes reformas rivadavianas gestadas en Buenos Aires, asi como la lectura de la obra Origen, Desarrollo y Progreso del Sistema Lancaster, cuya introducción en el país se habría realizado en 1819, registrada en la Universidad de Buenos Aires fueron conocidas simultáneamente en Carmen de Patagones. Una Sociedad de Educación homónima, responsable de la difusión del sistema lancasteriano, se había instalado en Buenos Aires. El 10 de junio de 1823, esta sociedad porteña conforma una junta dirigida por Manuel de Sarratea, publicando su reglamento en La Abeja Argentina, el 15 de junio de 1823.

\subsection{Análisis discursivo del Reglamento de Escuelas de Primeras Letras de Carmen de Patagones}

Los primeros once artículos de este reglamento demuestran que a través de procedimientos de argumentación, aplican en forma categórica el paradigma ilustrado rivadaviano, por cuanto, por una lado existe un proyecto moral y ético al llamarse «protectora de la educación de la educación». Existe por ende el compromiso de los sujetos que la integraban configurar un modelo educativo en un contexto geográfico dado, que «determinarían» los cambios curriculares necesarios para «ordenar» la juventud. Por otro lado, al considerar en su artículo $2^{\circ}$ «que la sociedad es independiente de la autoridad pública en sus funciones», podemos entender que este organismo es autónomo y con un futuro de acciones subjetivas a las que determinaran sus miembros. Pertenecerían a esta sociedad «todos los individuos q_e se suscriban con alguna cantidad pa. El establecimiento y conservación de la Escuela de primeras letras». La pretensión esencial es una apertura hacia toda la comunidad del pueblo, pero sus miembros deberían ser capaces de aportar económicamente para su funcionamiento ${ }^{263}$.

La Sociedad se reuniría el primer domingo de cada mes inmediatamente después de la misa que se celebraría en la sala. Este requisito parecería ir a contramano de las reformas rivadavianas que desde el discurso pretendían luchar contra el arcaísmo de instituciones o prácticas religiosas del pasado colonial. La obligatoriedad de la asistencia a un ritual religioso no hace otra cosa que beneficiar la persistencia de una simbología que cuesta desterrar: «...es una obligaci.n de honor de cada socio de asistir a esta reunión estad.ca(sic) como uno de sus mas caros deberes».

${ }^{262}$ AGN, Sala X, C-13-A4.

${ }^{263}$ AGN, Sala X, C13-A4. 
El Juez de Paz era el representante permanente de la ciudad en esta sociedad, que tendría como miembros un presidente, un secretario y un tesorero. Ellos integrarían una comisión permanente de cinco socios «amovible por cuatrimestres p.a q.e obre a nombre de la sociedad en todos los casos q.e demanden intervenir» (art. $8^{\circ}$ ). El mensaje de este quienes vieron a la escuela pública como una forma de control social al mantener entre sus miembros a vecinos distinguidos o con poder político y jurídico o que integraban minorías étnicas. Dentro de las funciones de la comisión estaban las de visitar la escuela dos veces por semana para observar los progresos y necesidades de la misma. Al igual que «velar por la conducta del Preceptor y informar ala sociedad en las sesiones del resultado de sus trabajos» (art. 19). Corresponde en este punto reflexionar sobre el concepto de panóptico empleado por Bentham:

Invisible el inspector reina como un espíritu; pero en caso de necesidad puede este espíritu dar inmediatamente prueba de su presencia real. Panóptico para espresar con una palabra su utilidad esencial, es la facultad de ver con una mirada todo cuanto se hace en ella ${ }^{264}$.

La Comisión se arrogaba el derecho de velar sobre la conducta de los padres como un reaseguro de «las costumbres» y la «moral» de los hijos: «...velará muy especialmente sobre este interesante particular y delatara a la Sociedad al Padre indolente que distancia con su mal exemplo la obra del preceptor ${ }^{265}$. Este artículo permite la interpretación explícita de control social al definirse como instrumento no solo de cambio en el conocimiento sino en la reproducción de nuevas formas culturales que moldearían un nuevo individuo. Por último, la función del tesorero sería recibir mensualmente todas las contribuciones para el pago de los gastos correspondientes.

El preceptor debería informar a la comisión sobre los alumnos que fueran distinguidos por «su aplicación y adelantam.to y con acuerdo la presentaran a la sociedad, quien acordara los premios aqe. Se hayan hecho acreedores» (art. 21).

Emma Nozzi atribuye la iniciativa de la creación de esta escuela pública al comandante José Gabriel Oyuela, quien según la autora, antes de emprender viaje a Patagones se habría interiorizado de este método asistiendo a clases de James Thompson ${ }^{266}$. Este hecho no ha podido ser constatado documentalmente.

${ }^{264}$ Bentham, J. Op. cit., págs. 542-543. Si bien este filósofo está haciendo referencia a los institutos carcelarios, la aplicabilidad del control, separación por sexos, separación por clases sociales, modos de instrucción, uniformes y la vigilancia se trasladan a instituciones educativas, legislativas y religiosas en lo referente a los primeros planos arquitectónicos que guardarían estas formas. Aliata, F. «Cultura urbana y organización del territorio», en: Goldman, N. Nueva Historia Argentina, Tomo III 1806-1852, Buenos Aires: Sudamericana, 1998, págs. 105-124.

${ }^{265}$ AGN, Sala X, C13, A-4, artículo 24.

${ }^{266}$ Nozzi, E. Carmen de Patagones y su Proceso educativo. Homenaje del Museo a la primera escuela pública patagónica. 1821-agosto-1971, Carmen de Patagones, Museo Histórico Regional Municipal de Patagones, Dirección de Impresiones del estado y Boletín oficial, La Plata, 1972, pág. 19. 
El 1 de mayo de 1823 el comandante Oyuela acompaña al comandante «Político y Militar de Patagones» nota y ejemplar del Reglamento que ha formado la Sociedad Protectora de la Escuela ${ }^{267}$. Recepcionado por el gobierno central el citado reglamento «..qe.ha formado la Sociedad Lancasteriana Protectora de la educación de la juventud... (requiere) ... que el citado Comandte. Consagre todos sus empeños á proteger y promover su adelantami.to con el interés que demanda la civilic.n y prosperidad de este importante punto de la provincia» ${ }^{268}$. De ambas notas se desprenden no solo la descripción de un acontecimiento cultural enmarcado en un espacio de claro aislamiento, sino la justificación de modificaciones en el concepto del ciudadano y la existencia de un consenso en los cambios axiológicos de sus pobladores.

«Todo discurso legítimo contribuye a legitimar prácticas y maneras de ver, dice Marc Angenot, a asegurar beneficios simbólicos» ${ }^{269}$. En esta línea de análisis la cosa impresa es un instrumento de legitimación para quienes creen sin reservas lo que está escrito en un periódico o un diario, forma de legitimar y controlar. Ciertamente los discursos de control son indispensables para que los cambios sociales o culturales funcionen. Los periódicos en esta etapa constituían una forma de reproducción de la vida social, de las costumbres, de la política, de la ciencia y de la educación, acompañados por símbolos, eslóganes y justificaciones para aplicación de los cambios políticos pretendidos. La Abeja Argentina en defensa del éxito probado en Asia del sistema lancasteriano, apuntará en uno de sus artículos:

¿Ni cómo será posible dudar que tal sea el éxito de esta sociedad en Buenos Aires, cuando en Patagones, esto es en el último extremo de la provincia, en un pueblo de 800 habitantes, a una distancia enorme de todos los elementos que engendran inclinaciones semejantes, se ha formado y marcha con dignidad una sociedad particular con 60 subscriptores, que al paso que contribuye con un sobresueldo al preceptor dotado por el estado, costea premios para los alumnos, que se distingan y tiene á su cargo la inspección y protección de la enseñanza? ${ }^{270}$.

Los vecinos Andrés Paz y Manuel Álvarez, este último como secretario de la Sociedad, en nota dirigida al comandante de la campaña, manifiestan conocer «las ventajas qe. Va a reportar al país de su permanencia y duración» como miembros de esta comisión estando «prevenidos del modo posible los embarazos q.e pudiera retardar los progresos de la educación de la juventud, objeto único de su filantrópico empeño...» ${ }^{271}$.

Analizando discursivamente estos párrafos del documento el grupo que ha conformado la sociedad lancasteriana, consciente de la coyuntura histórica que vive, haciendo conocer que su creación «hará

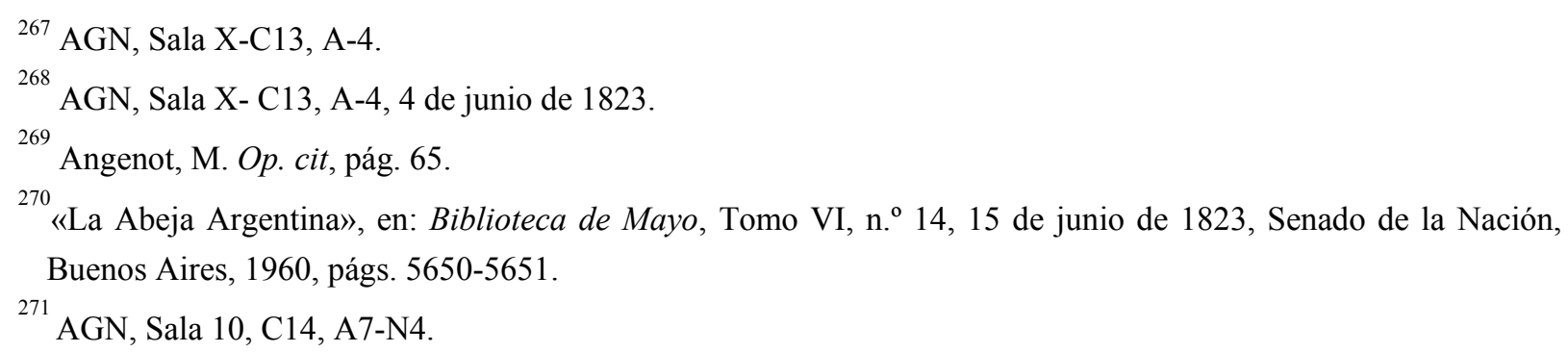


historia», que al abordarlo desde lo axiológico vemos una valoración de su acción que pone fin a una supuesta etapa de barbarie y da inicio hacia la «civilización» de la campaña.

\subsection{El rosismo y su compromiso educativo en la visión de testigos e historiadores}

Durante más de tres décadas a partir de la caída de Rivadavia (1827), se puede contemplar una paulatina transformación en las prácticas educativas, en las reformas educacionales, en el pensamiento y mentalidades de organizaciones filantrópicas. Este proceso iniciado a partir del gobierno de Dorrego y continuado durante toda la etapa rosista con diferentes matices, hubo un control directo del Estado sobre las normas, contenidos y organización de la enseñanza pública y privada. Para comprender esta etapa analizamos historiográficamente el abordaje que realizaron algunos de los autores sobre el rosismo diferenciando el relato literario-educacional a las interpretaciones y consideraciones epistemológicas sobre los cambios en un contexto histórico.

Dentro de las miradas de los contemporáneos las confrontaciones ideológicas y las controversias filosóficas de oposiciones a veces insalvables cuando los juicios argumentativos permanecían estáncados en su «propia verdad». Nicolás Avellaneda, en unas páginas inéditas que rescata en su Biblioteca Paul Groussac, recorre la gestión de Rivadavia enfatizando la generación de instituciones políticas modernas como el Congreso, la Constitución, la Capitalización de Buenos Aires que permiten ponderar su accionar. Encuentra ya en el gobierno de Dorrego la destrucción de lo construido en el campo institucional y en el movimiento intelectual y artístico de su antecesor. Lo sombrío, lo atrasado, lo receloso, aparece — según Avellaneda — «en el criollismo más neto representado por el compadre, quien se burla del sabio extranjero que se ha hecho venir de Europa». Como testigo de la época fundamenta este panegírico a la obra rivadaviana, entendiendo que «...la renuncia de Rivadavia abrió paso franco al predominio de la barbarie en sus formas más odiosas» ${ }^{272}$.

Sus contemporáneos gustaban descalificar en su discurso a Rosas por su supuesta escasa formación educacional y por ende intelectual que entendían restaba méritos a su comportamiento político. Esta escasez de dones «intelectuales o artísticos» conducía a una percepción unilateral en sus testimonios que demuestran como estos sujetos hablantes estaban comprometidos en comunicar un determinado «mensaje». William Mc Cann, en 1847 describe a un Rosas «espontáneo y agradable» en el trato dispensado. «Me relató varios episodios de su vida juvenil, me dijo que su educación había costado a sus padres unos cien pesos porque solamente fue a la escuela por espacio de un año. Su maestro solía decirle: "don Juan ud. No debe hacerse mala sangre por cosas de libros, aprenda a escribir con buena letra, su vida va a pasar en una estancia, no se preocupe mucho por aprender...» ${ }^{273}$. Xavier Marmier en

272 Avellaneda, N. «Rivadavia», en: Groussac, P. La Biblioteca, Año II, Tomo IV, Buenos Aires: Librería Lajouane, págs. 222-240.

${ }^{273}$ Mc Cann, W. Viaje a caballo por las provincias argentinas, Traducción José Luis Busaniche, Capítulo IX, Buenos aires: [s/e], 1939. 
la descripción que realiza sobre los indígenas asentados en Santos Lugares pone acento en una breve frase diciendo que «....arrastran una especie de vida animal sin aliento y sin fuerza. Ningún ser compasivo se ocupa de aclararles la mente o mejorar su estado material ${ }^{274}$. En el examen e interpretación discursiva de testigos de la época resulta indispensable comprender de dónde vienen estos hombres y cómo se relacionan con los diferentes actores de una época en un espacio que resulta ajeno y exóticos. Al igual tener en cuenta que quienes escriben y analizan están impregnados de componentes que responden al naciente evolucionismo y cientificismo de la época.

Hernán F. Gómez realiza un estudio de la educación común a nivel nacional bajo los esquemas de análisis histórico-tradicionales. De carácter descriptivo, y haciendo referencia a la educación de su provincia, Corrientes, no se aparta del propósito primario de su obra: «(hacer) una historia de la instrucción primaria entre los argentinos ... convencido con la filosofía de que la educación común impartida a un pueblo influye en la preeminencia en el sello de su cultura ${ }^{275}$. Valoriza la labor de Rivadavia durante su gestión sobre la escuela pública y rescata la presencia del agrimensor Narciso Parchape como educador en esa provincia mediterránea. Tal como hemos indicado anteriormente este agrimensor y educador tuvo un rol muy importante en la fundación de Bahía Blanca — como director de la primera escuela de primeras letras de esa provincia bajo la gobernación de don Pedro Ferré (1 de enero de 1827) - Al explorar el contexto histórico-educacional durante las gobernaciones de Atienza y Berón de Astrada en la etapa rosista, entiende que existió idéntico abandono al resto del país.

Adriana Puiggrós, por una parte, enfatiza la aspiración de Rivadavia de formar una minoría esclarecida y privilegiada, caracterizada por una mentalidad moderna, utilitaria y economicista. Por otra, Rosas sería la contracara a esta propuesta educacional al titularla «religión o muerte». Puntualiza aspectos como la exaltación de lo popular, del modelo prohispánico y localista, la libertad de mercado de la educación a favor de la escolaridad privada y en contra de la obligatoriedad escolar. Este último aspecto favoreció el crecimiento sustancial de las escuelas privadas de origen clerical o de inmigrantes europeos ${ }^{276}$.

Existen en esta etapa variables que giran en torno al libro y las prácticas de la lectura. Prueba de ello fueron un plan sistemático de destrucción de títulos que no compatibilizaran con el régimen, la persecución y posterior exilio de intelectuales liberales u opositores y el cierre del Salón Literario, la limitación del número en la circulación de periódicos, revistas, la homogeneidad discursiva del Archivo Americano como la voz autorizada por el poder central. A nuestro entender todas estas acciones constituyen signos de prácticas de gobernabilidad que fueron múltiples pero definían una política educativa verticalista: el padre de familia — Rosas - es pedagogo y maestro en relación a niños y discípulos, resolviendo qué se puede decir y cómo se debe leer. Reinhard Wittmann al analizar la lectura

${ }^{274}$ Marmier, X. Buenos Aires y Montevideo en 1850, Traducción José Luis Busaniche, Buenos Aires: ACNLP, pág. 83.

${ }^{275}$ Gómez, H. La educación común entre los argentinos. 1810-1934.Estudio de la educación común en lo nacional y en lo provincial tomando como tipo de esta última a la impartida en la provincia de Corrientes, Corrientes: [s/e], 1935, pág. 25.

${ }^{276}$ Puiggrós, A. Que pasó en la educación argentina desde la conquista hasta el Menemismo, Buenos Aires: Kapelusz, 1996, págs. 40-45. 
de fines del siglo XVIII en Alemania, considera que el tiro de gracia al Antiguo Régimen lo dieron las técnicas de lectura aplicadas por los revolucionarios y combatida por las clases reaccionarias y conservadoras ${ }^{277}$. Por ende, el control sobre el uso de determinados libros constituía un factor de todo proceso disciplinador en un régimen autoritario o para las autoridades eclesiásticas.

Puiggros enfatiza otras medidas homogenizadoras de la política educativa rosista como los contenidos de los programas escolares, la exigencia a los docentes de adhesión al gobierno, la cesantía de quienes se negaban, el uso de la divisa punzó tanto para docentes como niños y niñas de la Sociedad de Beneficencia. Considera que el sistema rivadaviano habría sido desmantelado con el crecimiento paralelo de las escuelas privadas, entre las que se destacó la de Marcos Sastre. La autora pone su acento en el valor indiscutible que tuvo en las resoluciones educativas de la etapa rosista don Pedro de Angelis, miembro revisor de la comisión de libros de textos, hombre contradictorio que había compartido las experiencias liberales del sistema Lancaster con la creación de «El Ateneo» ${ }^{278}$.

Carlos Newland analiza la educación primaria privada durante el gobierno de Rosas (1835-52) buscando clarificar las ideas contrapuestas sobre esta etapa por los autores como Portnoy, Evaristo Iglesias, Salvadores, Gras, Correa Luna, Leonardo Paso y Fermín Chaves. Coincide con Puiggrós en el desfinanciamiento estatal a la educación pública y la concepción ideológica rosista que la instrucción llevaba a la improductividad de las clases humildes, temiendo que la gratuidad y la educación estatal favorecerían el surgimiento de demagogos y de quienes quisieran perturbar el orden público ${ }^{279}$.

Jorge Gelman sostiene que Rosas pretendía en su programa político un restablecimiento de la autoridad y el orden, entendiendo que la anarquía reinante había subvertido esos valores pulverizando entre otras cosas la disciplina. El ideario político era para Gelman netamente conservador aunque mantenía una postura liberal en lo económico ${ }^{280}$. Frente a este análisis podemos inferir que las prácticas educativas a poner en marcha en especial en la campaña requerían del disciplinamiento de los actores (maestros, preceptores, alumnos) que podía ser llevado a cabo por quienes tuvieran fueran los receptores del poder (los militares, los jueces de paz, los comandantes de frontera) en los pequeños centros urbanos que se iban formando en la medida que se concretaba el avance de fronteras.

John Lynch observa — según su criterio - que Rosas no era antibritánico sino que durante sus gobiernos manifestó un profundo interés en mantener relaciones con Gran Bretaña. Concepto disímil de quienes lo han manifestado que el régimen rosista era profundamente xenófobo. Para este autor el gobierno de Buenos Aires facilitó la apertura de templos anglicanos, presbisterianos y metodistas, de un club británico con «salones de lectura». Diciendo, «había también escuelas británicas que florecieron

${ }^{277}$ Wittman, R. «¿Hubo una revolución en la lectura a finales del siglo XVIII?», en: Cavallo, G. y Chartier, R. (dirs). Historia de la lectura en el mundo occidental, Madrid: Taurus, 1998, págs. 26-27.

${ }^{278}$ Puiggrós, A. Op. cit., pág. 43.

${ }^{279}$ Newland, C. «La educación primaria privada bajo el gobierno de Rosas (1835-1852)», La Nación, 4 de diciembre de 1988, Sección 4a.

Newland, C. Buenos Aires no es pampa. La educación elemental porteña 1820-1860, Op.cit.

${ }^{280}$ Gelman, J. «Derechos de propiedad, crecimiento económico y desigualdad en la región pampeana, siglos XVIII y XIX», en: Historia Agraria, n. ${ }^{\circ 37}$, diciembre, 2005, págs. 467-488, SEHA. 
hasta 1844, en que los decretos del gobierno empezaron a acosarlas con pruebas políticas y religiosas ${ }^{281}$. Las escuelas quedaban sometidas a los reglamentos de la policía. Si bien las instituciones escolares siguieron funcionando lo hicieron bajo la constante amenaza de la policía. Por su parte los extranjeros no estaban dispuestos a enviar sus hijos a escuelas argentinas, aplicando ya la costumbre de enviar sus hijos a estudiar a Europa o a Estados Unidos. Los bloqueos al comercio de Buenos Aires por los franceses (1838-40) y británicos y franceses (1845-47), fueron, para Lynch, causales directos de medidas de un mayor control económico-educacional dispuestas por Rosas.

Myers analiza la producción discursiva del rosismo que según este autor, no difirió del modelo rivadaviano durante la primera etapa, sino que aún los acentúa, como una manera de logros y rendición de cuentas, enfatizando los valores de signo ideológico de quien presidía la administración. Existía la plena certeza que el discurso - ya sea a través de los mensajes del gobernador como de la prensa - eran el medio más adecuado para dejar sentadas las bases del pensamiento rosista ${ }^{282}$.

En una reciente tesis publicada, el historiador José Bustamante Vismara afirma que la redesignación de Segurola en el cargo de inspector general no implicó el cierre generalizado de las escuelas ni el cambio de perfil de las mismas. Este autor a través de un arduo relevamiento documental que la educación privada no desaparece totalmente, aunque reconoce la exclusión de la educación de los sectores más bajos de la población, en especial entre 1844 a $1846^{283}$. Para este autor la redesignación de Segurola del cargo de inspector de escuelas en 1828, no implicó el cierre generalizado de escuelas ni la discontinuidad de la aplicación del sistema lancasteriano, como lo sostiene Antonino Salvadores. Considera que la batalla de Caseros de 1852 implicará la reestructuración del sistema educativo bonaerense con la derogación del Decreto . $^{\circ} 1838^{284}$. Según los nuevos criterios que aplica en el análisis de la historia educacional bonaerense la escuela se convierte en «centro de poder», «difusor de nuevas lecturas», el propician cambios en las condiciones de vida y desarrollo social y su relación con las formas de producción de determinadas regiones ${ }^{285}$. Si bien el estudio de Vismara está enmarcado dentro de una historia social de la educación de la campaña, quedan relegadas en este vasto y rico análisis con fuentes documentales, la región del sudoeste punto clave de nuestro interés.

\subsection{Nuevos códigos de la política educativa rosista}

A partir de 1828, durante el gobierno de Dorrego, se inicia un proceso paulatino de transformación educativa: se separa la Dirección General de Escuelas de la campaña del gobierno de la Universidad de

${ }^{281}$ Lynch, J. Juan Manuel de Rosas. (1829.1952), Buenos Aires: Emece, págs. 258-259.

${ }^{282}$ Myers, J. Orden y virtud. El discurso republicano en el régimen rosista, Buenos Aires, Universidad Nacional de Quilmes, 2004.

${ }^{283}$ Bustamante Vismara, J. Las escuelas de primeras letras en la campaña de Buenos Aires (1800-1860), La Plata, Archivo Histórico «Ricardo Levene», Instituto Cultural de la provincia de Buenos Aires, 2007, págs. 71-79.

${ }^{284}$ Idem, págs. 82-83.

${ }^{285}$ Idem, págs. 21-26. 
Buenos Aires y se crea el cargo de un inspector general que dependería del ministerio de Gobierno produciéndose una serie de cierre de locales escolares ${ }^{286}$. Esta medida descentralizadora terminaría desvinculando el problema de la educación de la campaña de una intelectualidad que mantenían un mayor compromiso con las ciencias y a su vez eran productores del saber, en tanto realizaban publicaciones, investigaciones y lecturas que permitían el estudio de divergencias y cortes gnoseológicos y $\operatorname{argumentativos}^{287}$. En su corto paso por el gobierno de Buenos Aires, Dorrego manifiesta su voluntad de prevenir las interrupciones que sufría la enseñanza en las escuelas dotadas por el Estado y que provocaban el abandono de los cargos por parte de los docentes. Buscó endurecer el rol del Estado a través del sistema de contratos con el Inspector General de Escuelas ${ }^{288}$. El golpe del 1 de diciembre de 1828 y el posterior fusilamiento del líder federal en Navarro marcarán el fin de una etapa.

En 1829 se pone en vigencia el nuevo Reglamento de Escuelas, reemplazando al de 1818 y por el cual se creaban las «Juntas de Inspectores» o «Juntas de Campaña» que deberían levantar información sumaria y destituir maestros en casos de probar irregularidades. Se mandó a imprimir el Tratado de las Obligaciones del Hombre, argumentando a su vez la escasez de medios materiales y de libros. Si realizamos un recorrido retrospectivo del gobierno rosista podemos apuntar que existió un cambio en los actores que participarían de la política educativa. Acciones de cierto voluntarismo e improvisación ponen en las manos de los jueces de paz la responsabilidad de la difusión de la enseñanza en la campaña. Se busca mejorar mejorar el sistema educativo de la mujer con la creación de escuelas de niñas en algunas localidades cercanas a Buenos Aires como San Fernando y Luján, manteniendo los premios a la moral y la aplicación como en la época rivadaviana.

Durante el gobierno de Balcarce existirá un mayor control estatal sobre la apertura y el funcionamiento de los colegios privados, que católicos o no, debían realizar durante los días sábados la lectura de la doctrina cristiana por el Catecismo del Padre Astete ${ }^{289}$. Esto provoca el cierre de muy pocas escuelas privadas como la protestante del Almirante Brown. A partir de 1831 se observará un mayor control sobre los maestros en lo que respecta a su compromiso con las máximas de federación y principios cristianos:

${ }^{286}$ AHPBA, libro 1826 a 1851, n. ${ }^{\circ} 315$, folios 28-29.

${ }^{287}$ Debemos tener en cuenta en esta intelectualidad universitaria a Fernández de Agüero, Juan Manuel y Diego Alcorta. Este último fue autor de los primeros estudios de psiquiatría del país en su tesis presentada ante la Facultad de Medicina en 1827. Sucedió a Lafinur y posteriormente a Fernández de Agüero en su cátedra de Ideología. Respondía a un movimiento filosófico que integraba el racionalismo analítico francés con el empirismo inglés. Profesor de Alberdi, Gutierrez y Vicente Fidel López, introduce a los miembros de la Generación del 37 en su posterior accionar con el gobierno rosista.

${ }^{288}$ AGN, sección gobierno, Inspección General de Escuelas, Sala X, C.6, A 1- n. ${ }^{\circ} 6$.

${ }^{289}$ El decreto gubernamental es citado por Iglesias Evaristo y extraído del Registro Oficial de la Provincia de Buenos Aires. Febrero 8 de 1831. Se consultó además en la Biblioteca del Maestro. Ministerio de Educación de la Nación. Catecismo de la doctrina cristiana escrito por el Padre Gaspar Astete, París: Librería de Garnier Hnos., 1879. 
...convendría alejar de todas las escuelas todo maestro conocido o sospechoso de unitario, y por consiguiente capaz de pervertir a los niños con opiniones antisociales...prefiriendo siempre para preceptores aquellos sujetos que a las aptitudes de suficiec.a(sic) en el Arte, religión Católica, buena moral y urbaninadad reuna(sic) una fiel y sincera adheccion(sic) al predicho sistema ${ }^{290}$.

A este decreto lo sucedió otra medida que iba indicando un claro giro hacia la hegemonía del partido federal con actitudes radicales como el uso obligatorio para los maestros de la divisa punzó. Siguiendo el pensamiento de Le Goff, el valor simbólico y adopción de una señal, que colocada en el pecho (pectus) y/ o en el corazón (cor) de una persona, como sedes del pensamiento y del sentimiento, nace del cristianismo romano ${ }^{291}$. La valoración y rigidez en la aplicabilidad de este símbolo son indicativos de la necesidad -en nuestro caso- de dominación ideológica de educadores y educandos.

A partir de su segundo gobierno la política cultural y las prácticas del conocimiento rosista se tornan más disciplinadas y rigurosas con sus actores: supresión de la obligatoriedad escolar, delegación a los jueces de paz de los temas educativos, retorno y protagonismo de la Compañía de Jesús en la anterior educación laica, la concepción de una educación femenina «religiosa, federal, industrial y modesta». La renuncia de Segurola en 1838 motivada por la falta de respuesta a la solicitud del pago de sueldos y sostenimiento de escuelas, fue indicativa del estado crítico del gobierno rosista, acuciado por el bloqueo anglo-francés que generaba graves problemas en la economía rioplatense, según consta en el decreto del 27 de abril del mismo año ${ }^{292}$. Rosas manifestaba su pretensión —en su mensaje a la Legislatura— que la educación pública sea «nacional, eficaz y útil» bajo los principios de «religión, virtud y patriotismo» ${ }^{293}$. En la práctica esto se traducía con la exigencia hacia los directores, maestros y preceptores de escuelas privadas de profesar la fe católica y un control sobre las lecturas adoptadas.

En este aspecto el periodista y educador don Pedro De Angelis, realiza una defensa y justificación de esta medida. Discursivamente entiende que el gobierno ha actuado «...con generosidad el derecho de abrir escuelas a todos los que la han solicitado...» protegiendo a los argentinos. En lo que respecta a escuelas abiertas por extranjeros «era natural que se arbitrasen medios para precaverse de los males a que expone la confianza limitada». La falta de control sobre qué leen los que leen pueden corromper «muy temprano la inteligencia y el corazón de los que llegaran algún día a influir en los destinos de su patria». Sobre el decreto de julio de 1846 entiende que «no impone ninguna traba a los preceptores que pueden seguir en sus cursos el método que consideren adecuado». No obstante entiende que es necesario prohibir obras contrarias a la religión católica y al sistema político del país. De sus palabras se desprende la fuerza de persuasión hacia el lector al entender como «sustancias ponzoñosas» enseñar doctrinas que

\footnotetext{
${ }^{290}$ AGN, sección gobierno, sala 5 C17 AII N6.

${ }^{291}$ Le Goff, J. Fragmentos para una historia del cuerpo humano, [s/l]: [s/e], págs. 13-26.

${ }^{292}$ Citado textualmente en Iglesias, E. Op. cit., págs. 272-273.

${ }^{293}$ Archivo Histórico de la Provincia de Buenos Aires «Dr. Ricardo Levene», Mensajes de los gobernadores de la provincia, 1822-1849, Tomo II, AHPBA, La Plata, 1976.
} 
fueran contra el «orden y la moral pública» ${ }^{294}$. Lejos parecían las palabras pronunciadas por este educador italiano al inaugurar durante el gobierno de Rivadavia El Ateneo colegio que estableció junto a Mora y Francisco Curel. Su objetivo sería «formar ciudadanos», entendiendo que el valor cívico era un virtud indispensable para una republicano.

Con posterioridad en su Ensayo histórico sobre Rosas reconoce el valor que este tuvo en su relación y el cultivo de la amistad con los pampas, atribuyendo los desaciertos de la campaña realizada al sudoeste bonaerense durante el gobierno de Martín Rodríguez, al haber desoído los consejos de Rosas. Es crítico con el tratamiento que le dieron estos gobiernos al «pampa», culpándolos de la «desmoralización del ejército y la dispersión de las milicias». Frente a una política de «sojuzgar a los indios», De Ángelis sostiene que por «primera vez se pensó en colonizarlos». En qué consistía esta colonización? Enseñar a labrar la tierra, herrar y apartar ganado, hacer ladrillos y para las mujeres «transquilar las ovejas», hilar, tejer lo que las llevaría al abandono de su natural pereza. Criticando a aquellos hombres «ilustrados que le hacían un cargo (a Rosas) de su interés por los indios» ${ }^{295}$.

De Angelis, paradójicamente, a pesar de la justificación que realiza a las medidas tomadas por Rosas a nivel educativo en cuanto a la prohibición de las lecturas escribe hacia la libertad de imprenta, que «distribuye igualmente a todos los hombres los conocimientos más diversos». Concluyendo con palabras altamente significativas, pero a su vez contradictorias con acción política:

Cuando el pueblo no sabía más que lo cada individuo puede aprender por sí solo, cuando había pocos libros y pocos hombres en estado de aprovechar de ellos, ni había opinión pública, ni aún siquiera público que mereciere este nombre. Hacíase el mal, y no llegaba a noticia de nadie. Los tiranos y sus satélites estaban seguros. ..Pero desde que la imprenta hace circular todas las ideas, todos los ojos se han abierto ${ }^{296}$.

El Archivo Americano tuvo una orientación en la redacción de sus artículos homogénea y disciplinada al régimen. «La orientación de la redacción debe tener una vigorosa organización para producir un trabajo intelectualmente homogéneo aún dentro de la variedad de estilos y personalidades literarias» ${ }^{297}$. El Archivo Americano se convierte en el periódico oficial donde parece que la polémica está excluída, quedando relegada a las publicaciones que desde el exilio realizaban algunos jóvenes de la Generación del 37 como José Mármol y Vicente Fidel López en las páginas de El Nacional de Montevideo. Rosas pudo sostener durante años y a través del concepto de diario oficial, manteniendo una información reducida y parcial ligada a los intereses de su grupo, manteniendo una estructura conservadora y a veces despótica. Con tendencia a titulares grandilocuentes que posicionan a la prensa opositora — como El

294 De Angelis, P. Acusación y defensa de Rosas. Compilación e introducción bio-bibliográfica por Rodolfo Trostiné, Buenos Aires: Editorial La Facultad, 1946, págs. 365-367.

${ }^{295}$ De Angelis, P. Op .cit., págs. 200-203.

296 «Ideas sobre la época presente», en: De Angelis, P. Op. cit., págs. 287-291.

${ }^{297}$ Gramsci, A. Los intelectuales y la organización de la cultura, op. cit. pág. 156. 
Nacional de Montevideo- y «su inmundo editor» realiza argumentaciones en defensa de no solo su política interior y exterior sino el fomento de las ciencias que el General había logrado:

\begin{abstract}
Una comisión integrada por D. Pedro de Angelis, y D. Pedro Pablo Vidal se ocupó del arreglo y sistema de la Universidad. ...Las escuelas se organizaron. Los Registros y demás publicaciones oficiales fueron mejorados. Se reunieron y publicaron memorias importantes sobre la historia de nuestra Patria y datos estadísticos de interés. Se dio impulso a la industria. Nuestros archivos...se reorganizaron y sometieron a un sistema de orden ${ }^{298}$.
\end{abstract}

En este mismo número procurará persuadir al lector sobre lo que llama «la obra gloriosa» de Rosas a favor del desarrollo de las ciencias exactas y naturales, la formación de un censo de población con tablas de nacimiento y mortalidad, la publicación de obras como los documentos históricos a cargo de De Angelis y la Memoria de Felipe Senillosa.

La expedición de 1833 y 1834 a los «Desiertos del Sud» no es calificada como un simple avance fronterizo sino que también había permitido al General «...dirigir y organizar una serie de observaciones y datos importantes para la descripción geográfica y geológica del país para su historia natural y antigüedades ${ }^{299}$. Pone énfasis en el comportamiento de los oponentes a la política cultural y educativa rosista y a quienes define como «tránsfugas», «salvajes unitarios»o «ignorantes» con expresiones referenciales subjetivas de evaluación axiológica. Para Rosas el periodismo permitiría tener informado a todos los ciudadanos sobre la actividad estatal, estrategia que impediría que un opositor argumentara el «desconocimiento de las leyes».

Como conclusión parcial de este período podemos indicar brevemente y en comparación con la etapa rivadaviana, las diferencias que caracterizaron una nueva concepción educacional, en especial a partir de 1833, que tendrá su reflejo en la frontera sur. El análisis de sus mensajes como gobernador, se observa la repetición de dos valores que caracterizarían la educación del ciudadano de la campaña: el orden y el respeto a la ley. La escuela era a su vez un vehículo de salud, como lo manifiesta Balcarce en su mensaje a la legislatura y se convierte en una práctica educativa en la voz del maestro de Patagones, Manuel de Hoz: «...le providence y si es posible, y está a su alcance, en lo concerniente a la vacuna, con dificultad habrá tres niños que estén vacunados» ${ }^{300}$.

Dos variables se combinan en el modelo educativo de Rosas: la utilidad y la defensa a ultranza de la religión. De acuerdo a su concepción, ambas variables debían fusionarse en el modelo educativo por él planteado. El regreso de la Compañía de Jesús y la protección a ella, significaba devolver el protagonismo de la Iglesia como educadora.

La desprotección económica de la educación orientada más hacia «lo útil y necesario», favoreció que las escuelas de varones de campaña deberían ser costeadas por «el ramo de los corrales». Mientras que

298 Archivo Americano y espíritu de la prensa del mundo, Primera reimpresión del texto conforme a la edición original, 1843-1851, Buenos Aires: Americana, 1947, n. ${ }^{\circ}$ 16, diciembre, 11 de 1844, pág. 86, Tomo II.

${ }^{299}$ Archivo Americano y espiritu de la prensa del mundo, op. cit., n. ${ }^{\circ} 16$, diciembre, 11 de 1844, págs. 73-75.

${ }^{300}$ AHPBA, 1015, 16-8-1834. 
las de las niñas seguirían bajo el sostén de la Sociedad de Beneficencia. Los fundamentos sobre los que se asentó la educación de este período quedaron resumidos en el decreto del 19 de marzo de 1835 y en la Promulgación del Reglamento para Escuelas del 26 de octubre de 1844:

a) El total rechazo a los principios liberales sostenidos por Rivadavia y sus apologistas, ponían de acuerdo a su concepción, peligro en la identidad de la patria. Por tanto resultaba necesario «conservar» y no derrumbar las instituciones «útiles», dándole a las mismas un carácter «nacional».

b) Prescindir de los modelos extranjeros propios de la «charlatanería moderna», causales del caos y anarquía de toda América latina.

c) Una educación verticalista, en cuanto a lo que doctrinariamente aseguraba el «feliz o infausto porvenir de un pueblo». 


\section{Capítulo 2}

\section{La educación como determinante socio-cultural en la ocupación de la frontera del sudoeste bonaerense}

\section{Militarización y educación en la Ciudad del Carmen}

Fradkin y Gelman coinciden que en la actualidad existen nuevas visiones sobre el mundo rural y que permiten observar relaciones sociales menos desiguales que les permitió mantener lazos entre sectores subalternos con los más privilegiados ${ }^{1}$. Este concepto puede extenderse a los sectores vinculados con las milicias — de fines del siglo XVIII y principios del XX — que mantuvieron una modificación dinámica en la «construcción cotidiana» de la autoridad con el cuerpo de milicianos según el espacio en que estaban asentados y el contexto histórico que les permitía su participación en conflictos bélicos defensivos o contra-ofensivos. La construcción del poder dentro del proceso de militarización y disponibilidad de tropas fueron relevantes en la frontera al acompañar, garantizar y transformar los liderazgos políticos a partir de la década del cincuenta.

Sara Mata de López, en coincidencia con los autores citados, aporta nuevas y renovadas perspectivas teóricas, que abrieron otras líneas de investigación sobre el problema de la guerra y la consecuente militarización a partir de 1808. Además, examina las consecuencias en el tejido social y en la cultura política de una sociedad atravesada por conflictos sociales y económicos, que adquirían nuevas significaciones $^{2}$. En nuestra propuesta no escapa indagar sobre las complejas relaciones entre las milicias rurales locales y los «ejércitos regulares» enviados por Buenos Aires buscando recuperar el

\footnotetext{
${ }^{1}$ Fradkin, R. y Gelman, J. «Actores intermedios y política en el mundo rural del siglo XIX», Anuario IEHS, n. ${ }^{\circ}$ 30, Tandil, Universidad Nacional del Centro, 2008, págs. 147-150.

${ }^{2}$ Mata de López, S. E. «Guerra, militarización y poder. Ejército y milicias en Salta y Jujuy. 1810-1816», Anuario IEHS, n. ${ }^{\circ} 24$, Tandil, Universidad Nacional del Centro, 2009, págs. 279-298.
} 
accionar de los grupos subalternos, la participación de afromestizos, esclavos, indios, y en el caso particular de la Ciudad del Carmen, de los penitenciarios. Identificar quienes por su grado de alfabetismo tenían capacidad de movilizar grupos y actores en razón de sus capacidades intelectuales y su experiencia militar.

En este punto hacemos nuestro el concepto de Luis Miguel Glave que sintetiza el valor del conocimiento en una frase: «por la palabra también se lucha». Teniendo en cuenta que el campo de la palabra fue un terreno de creación y lucha que acompañaba a las ideas: «Leer, escribir, hablar, tres verbos de una misma textura cultural, la comunicación» ${ }^{3}$. Tal como lo sostiene Giddens la escritura es una forma de comunicación y al comprender a esta como un signo de interpretación del individuo del mundo que lo rodea ${ }^{4}$. Por lo tanto, podemos inferir, que aquellos milicianos y miembros del ejército regular que pudieran escribir o tuvieran la capacidad de leer funcionarían en los diferentes estamentos sociales por un lado como vasos comunicantes entre ellos, pero por otra parte, estos dominios fortalecerían el poder político y militar de los primeros.

Previo a la creación del Virreinato del Río de la Plata el imperio contaba con una dilatada frontera. Las relaciones con los indígenas eran relativamente pacíficas hasta 1740 cuando se inician incursiones en las poblaciones. El reacomodamiento de los actores intermediarios - peones, esclavos, presidiariosfueron claves en los sectores rurales generándose situaciones de hostilidad entre estos y los indígenas, que condujo a las autoridades a la necesidad de crear un cuerpo militar: los Blandengues de frontera en $1751^{5}$. Estos actuaron en la frontera sur en forma más tardía que en la frontera de Santa Fe y Chaco, siendo inicialmente una fuerza miliciana que se transformó en regular. Era una fuerza móvil capaz de repeler indígenas que consolidaron una línea de fortines.

En el período que se extiende desde la fundación de la Ciudad del Carmen en 1779 hasta las reformas militares de la etapa rivadaviana (1821-27), tanto los milicianos como la oficialidad se sostienen sobre variables predictivas como:

La incomunicación geográfica de los centros del poder central.

El aislamiento por tierra y mar en espacios visualizados para el destierro - como fuera analizado oportunamente con otros actores sociales - y que conjugados con factores climáticos adversos, complejizan un servicio eficiente en la organización de las tropas. La carencia de vestuario adecuado al clima, la escasez de recursos para enfrentar enfermedades mortales como el escorbuto, fueron elementos suficientes que se reflejaban en la evitación de la incertidumbre y malestar emocional de la tropa con sus superiores jerárquicos.

En este espacio, los actores intermediarios definidos como «los de abajo», «al ras del suelo», adquieren una mayor visualización por la necesidad de la oficialidad de contar con sus estrategias

${ }^{3}$ Glave, L. M. «Por la palabra también se lucha. Domingo Sánchez Rebata y Manuel Lorenzo de Vidaurre en la crisis colonial peruana», Anuario IEHS, n. ${ }^{\circ}$ 24, Tandil, Universidad Nacional del Centro, 2009, págs. 201-225.

${ }^{4}$ Cfr. Giddens, A. Sociología, Madrid: Alianza, 1997, págs. 110-113.

${ }^{5}$ Beverina, J. C. El Virreinato de las provincias del Río de la Plata. Su organización militar, Buenos Aires, Círculo militar, Biblioteca del Oficial, págs. 216-219. 
de comunicación con el indígena. Sobre este último aspecto social las tropas enviadas en primera instancia a Carmen de Patagones reflejan la pertenencia a diferentes grupos étnicos y sociales: los lenguaraces como «Gregorio» originario de Santiago del Estero; Lorenzo Calpisqui, indígena que establece un armisticio con alférez Lázaro Gómez; el negro intérprete de los indios Ventura Chapaco y la «interpreta» indígena ${ }^{6}$. El buen escribir constituye una de las tres partes de comunicación del discurso que plasma lo oral y facilita la circulación de impresos ${ }^{7}$.

El 27 de agosto de 1778 una expedición organizada en España arribó a Montevideo. El virrey Vértiz designa al teniente de infantería Pedro García, perteneciente al regimiento de Infantería de Buenos Aires, a cargo de la misma. Cuatro buques y dos embarcaciones con los primeros pobladores peninsulares arribarán en abril a la desembocadura del Río Negro.

El censo del 1 de octubre de 1784, nos permite visualizar los cargos de la denominada «tropa»: sus jefes, soldados y artilleros, dragones y miembros de la marina. Los primeros 11 nombres que figuran estaban encabezados por Juan de la Piedra, algunos ya han sido analizados en detalle en el capítulo I, en cuanto a su educación e instrucción recibida ${ }^{8}$. Al realizar un primer cotejo del censo podemos inferir que desde la fundación de la Ciudad del Carmen y hasta la primera década del siglo XIX, hubo convivencia entre miembros de las fuerzas militares y milicianos del virrey con inmigrantes españoles, con nativos indígenas, con criollos y prisioneros. En segundo lugar, nos revela la identidad de los oficiales y las funciones que le caben a ellos.

La falta de nombres de los subalternos permite avizorar por inferencia mediata de que ellos eran los anónimos, los «otros». El poder — en este caso de los oficiales o militares de mayores rangos - era ejercido por el acto mismo de ubicarlos en un espacio social. El otro no puede hablar, ni representarse a sí mismo porque se ve a sí mismo a través de los ojos del gobernante, o de la cultura dominante. Glosando a Eduardo Mendieta, la cuestión de subalternidad, de la dominación de control del otro, no es

${ }^{6}$ Entraigas, R. A. El Fuerte del Río Negro, Buenos Aires: Librería Don Bosco, 1960, págs. 79-81. Biedma, J. J. $O p$. cit., pág. 245. Este autor hace referencia a la buena caligrafía del alférez Gómez, casado con doña Francisca Obligado, distinguida familia de Buenos Aires: «...escritos con la hermosa letra de Gómez», en referencia a un «Diario» que tendría Pastor Obligado y ha sido una fuente de información del autor.

${ }^{7}$ El testimonio más elocuente es el de Faustino Ansay, exilado en Patagones en 1810, quien afirma que el Comandante Sancho «...nos preguntó de las ocurrencias en Buenos Aires, de donde no sabía nada desde su salida en Agosto». El piloto Callejas es quien informa a los presidiarios sobre la situación de Buenos Aires. Pero en este destierro los contrarrevolucionarios no solo agradecen a Callejas sino que reciben papel para poder escribir noticias y enviarlas a sus familias. Ansay dirá que el Guardalmacén hace entrega a ellos de diarios de La Coruña, «motivo para instruirnos de algunas cosas». Cfr. Ramírez, M. S. «El espacio de exilio en tiempos de la revolución», en: Tejerina, M. V. (comp.) Definir al otro. El Río de la Plata en tiempos de cambio (1777-1820), Bahía Blanca: Ediuns, 2012, págs. 139-174.

${ }^{8}$ Cfr. Capítulo I, páginas 14-18. 
solo una cuestión de otrificación ${ }^{9}$. Principalmente, se trata de impedir a los marginados y excluidos de representarse a sí mismos.

\begin{tabular}{|c|c|c|}
\hline \multicolumn{3}{|c|}{ Tropa } \\
\hline Nombre & Número & Cargo \\
\hline Juan de la Piedra & 1 & Comisario_Superintendente \\
\hline Francisco de Igarzábal & 1 & Contador y tesorero. \\
\hline $\begin{array}{l}\text { Fray Tadeo Gutiérrez, Fray Francisco } \\
\text { Bosques }\end{array}$ & 2 & Religiosos \\
\hline Sacristán Antonio Rodríguez & 1 & Soldado \\
\hline Josef Medianero & 1. & Guardalmacenes \\
\hline Juan de Cormis & 1 & Cirujano \\
\hline Pedro Méndez & 1 & Sangrador \\
\hline Juan Antonio Chinchón & 1 & $\begin{array}{l}\text { Contralor del Hospital. Sargento de } \\
\text { Infantería }\end{array}$ \\
\hline Pedro González Gallegos & 1 & Sobrestante de Reales Obras \\
\hline Josef Nuñez & 1 & \\
\hline Subtotal & 11 & \\
\hline \multicolumn{3}{|c|}{ Tropa de infantería } \\
\hline Nombre & Número & Cargo \\
\hline Isidro Bermúdez & 1. & Teniente \\
\hline $\begin{array}{l}\text { León Ortiz de Rozas, Salvador López y } \\
\text { Lázaro Gómez }\end{array}$ & 3 & Subtenientes \\
\hline No especifica nombres & 3 & Sargentos segundos \\
\hline No especifica nombres & 3 & Tambores. \\
\hline No especifica nombres & 6 & Cabos primeros \\
\hline No especifica nombres & 6 & Cabos segundos \\
\hline No especifica nombres & 98 & Soldados \\
\hline Subtotal & 120 & \\
\hline \multicolumn{3}{|c|}{ Artilleros } \\
\hline Nombre & Número & Cargo \\
\hline No especifica nombre & 1 & Sargento \\
\hline No especifica nombres & 13 & Artilleros \\
\hline Subtotal & 14 & \\
\hline \multicolumn{3}{|c|}{ Dragones } \\
\hline Nombre & Número & Cargo \\
\hline Francisco Xavier Piera y Domingo Piera & 2 & Alférez \\
\hline No especifica nombre & 1 & Sargento \\
\hline No especifica nombre & 1 & Cabo \\
\hline No especifica nombres & 16 & Soldados \\
\hline Subtotal & 33 & \\
\hline \multicolumn{3}{|c|}{ Marinos } \\
\hline Nombre & Número & Cargo \\
\hline Basilio Villarino & 1. & $\begin{array}{l}\text { Capitán y segundo piloto de la Real } \\
\text { Armada }\end{array}$ \\
\hline No especifica nombres & 3 & Contramaestres \\
\hline No especifica nombres & 2 & Pilotos \\
\hline No especifica nombres & 44 & Marineros \\
\hline Subtotal & 50 & \\
\hline Total & 228 & \\
\hline
\end{tabular}

Fuente: AGN, IX-16-4-4, en: Entraigas, R. A., op. cit., págs. 270-271.

${ }^{9}$ Mendieta, E. «La alterización del Otro: crítica de la razón latinoamericana», Cuadernos Americanos. Nueva Época, n. ${ }^{\circ}$ 62, México, UNAM, 1997, págs. 76-86. 
Este censo permite observar - además - la presencia de doce oficiales que constituían la plana mayor de las fuerzas veteranas del virreinato. Estos oficiales se formaban en los cuerpos veteranos peninsulares o en el virreinato ingresando en clase de cadetes pero con la condición de ser descendientes de nobles e hijos de oficial no menor al grado de capitán. Para la educación e instrucción del futuro oficial, además de la enseñanza de ordenanzas se les impartía conocimientos de aritmética, geometría y fortificación.

Antes de ser nombrado subtenientes o alférez el cadete debía pasar una categoría previa: la de abanderado o portaestandarte. La existencia de diferentes fuerzas con instrucción diferencial entre los altos mandos y subalternos permite identificar a quienes por sus prácticas intelectuales (leer, escribir, comunicarse) facilitará la construcción de nuevos esquemas de poder ocupando en la población maragata los cargos de Comandantes o Jefes del Fuerte. La petición de Biedma al virrey realizada el 29 de septiembre de 1780 en la que solicita el gobierno militar «...bajo las mismas reglas contenidas en reales militares ordenanzas...». De este petitorio se desprende la necesidad del marino de ser reconocido como autoridad ante el comandante de tropa de la guarnición como de sus oficiales y soldados, permitiendo un mejor gobierno según las reglas prescriptas por la Marina y el Ejército ${ }^{10}$. Se puede comprobar en estos enunciados las evidencias claras de un poder que subyace en quien es dueño de la palabra y de la comunicación.

En 1809, el capitán de infantería Antonio Francisco de Aragón reemplazará como comandante de Patagones a otro capitán de infantería, Luis A. Lahite, Según se desprende de las memorias de Faustino de Ansay, Aragón había sido educado con este contrarrevolucionario en las Academias Reales de la península ${ }^{11}$ En tanto el comandante Francisco Sancho a cargo de los presidiarios enviados por la Junta Revolucionaria de 1810, es calificado por Ansay como un hombre desinformado sobre los acontecimientos de Buenos Aires, tosco, recurriendo en algunos casos a un fraile o cirujano, aunque destacará como contracara al comisionado de presos José Mármol ${ }^{12}$. Este último, suegro de Callejas era mencionado reiteradamente como «amigo» por Ansay, durante el tiempo de su detención. Pero la valuación que le confiere a esta persona era el ser el agente que facilitaba la llegada y distribución de escritos a Buenos Aires de los prisioneros ${ }^{13}$. Existiendo, por ende, una correspondencia entre la valoración de la persona por su grado de formación en el dominio de la lectura y los escritos. Este aspecto resulta crucial para analizar la asociación de conocimiento y poder en diversos tipos de registro, sea de la crónica o de otras fuentes escritas.

La militarización de este enclave permite discernir cómo se produce la construcción de nuevas identidades políticas y sociales. La acción política de las autoridades virreinales es la que permite trastocar y transformar la estructura militar. Pero la estructura sola no se modifica si no está seguida de una práctica en la lectura, la escritura y la comunicación: en las peticiones escritas a los virreyes o

${ }^{10}$ Biedma, J. J. Op. cit., pág. 142.

${ }^{11}$ Biblioteca de Mayo, Memorias autobiográficas. Diarios y Crónicas, Tomo IV, Buenos Aires, Senado de la Nación, 1960, pág. 3404.

${ }^{12}$ José Mármol se había graduado de Capitán en el Regimiento de Dragones de Buenos Aires de donde era natural.

${ }^{13}$ Consideramos que hace referencia a quien Biedma denomina «inteligente piloto D. Juan Pascual Callejas» designado por el Virrey en 1780 y que debía realizar el plano del Río Negro, en: Biedma, J. J. Op. cit., pág. 97. 
escritas y orales a los subalternos y prisioneros políticos. Estas prácticas están vinculadas a los dominios del saber de estos militares y la participación de nativos, criollos y mestizos, quienes en la medida de un mayor crecimiento poblacional van adquiriendo mayor protagonismo político y social dentro de la Ciudad del Carmen.

Algunos miembros del regimiento de infantería, a través de nuevas formas de integración cívicomilitar, llegan a constituir en uniones familiares y parentales con los maragatos, el grupo de primeros pobladores que arriban al río Negro.

Llevando este fenómeno a un análisis teórico, militares y civiles construyeron otros modos de funcionamiento de las estructuras sociales de relación y vinculación político-cultural. El abandono que sufre Patagones por parte de las autoridades centrales y la emigración de las familias, nacidas de la unión de un militar con una natural de la población, llegó a alarmar al mismo virrey Sobremonte, como puede apreciarse en un informe ofrecido por el escribiente Fermín Indart.

Este último, recomienda al virrey como una forma de desalentar la despoblación del fuerte, evitar el ascenso o el relevo de todo individuo de tropa que se casase con hija de poblador, que llevaba a estas familias a abandonar la población. Para Indart lo conveniente era que obtenida la licencia quedase en «la clase de poblador» ${ }^{14}$.

El ascenso a subteniente del sargento del Real Cuerpo de Artillería Joseph Michain «en recompensa a sus muchos meritos» fue negado por el virrey Sobremonte en 1805, fundamentando la medida en la imposibilidad de adelantar un grado en la carrera militar. Biedma destaca la labor que este «modesto sargento» había llevado a cabo en la construcción murallas e iglesia del fuerte, donde había demostrado voluntad, pese a sus escasez de saberes técnicos. Un albañil, Bartolomé Vázquez, era quien lo asesoraba $^{15}$. En la construcción histórica que realizamos sobre este espacio —el colonizador y el hombre de la frontera - permiten visualizar una de las formas de relación interculturales entre milicianos con artesanos. Como sostiene Silvia Mallo, ciudades y pueblos de diferentes jerarquías, permiten la gestación de nuevas identidades con nuevas formas de adaptación y a su vez de comunicación ${ }^{16}$. El acto comunicacional se traduce a través del intercambio del conocimiento, entre quien sabe el oficio y sus técnicas y la voluntad de quien aprende. La transcripción de la firma de Michan no deja, a nuestro entender, de ser un dato más. Si sostenemos que la capacidad de escribir del individuo le permite una forma distinta de interpretación del mundo, la firma es el signo, es la huella, del dominio lingüístico, aunque no son directamente productores del saber.

Otros actores sociales, como el llamado «sargento Chinchón», que participa en la campaña de Undiano Gastellu, en 1809, era valorado por su capacidad de parlamentar y conocimiento de la lengua con el cacique Negro y con otros indígenas. En el caso del vecino Blas Guerrero que actuó como baqueano de

\footnotetext{
${ }^{14}$ Biedma, J. J. Crónica Histórica del Río Negro, op. cit., págs. 308-309.

${ }^{15}$ Biedma, J. J. Op. cit., págs. 100-109.

${ }^{16}$ Mallo, S. «Córdoba y Buenos Aires en la historiografía colonial», en: Moreyra, B. y Mallo, S. (comps.) Pensar y construir los grupos sociales. Actores, prácticas y representaciones. Córdoba y Buenos Aires, siglos SVI-XX, Centro de Estudios Históricos «Prof. Carlos Segretti» y Centro de Estudios de Estudios Históricos de América Colonial, La Plata, 2009, págs. 19-33.
} 
Rosas en la campaña de 1833 tiene experiencia y conocimientos prácticos de lo cotidiano y lo vivido, fortalecen su credibilidad. Paradójicamente, construyen nuevas formas de dominación, de sectores subalternos hacia la oficialidad, más que por saberes teóricos, por sus prácticas cotidianas. Son hombres anónimos que alcanzan su identidad cultural donde subsisten las normas de las milicias conjugadas con un hombre cercano al gaucho de la frontera ${ }^{17}$.

\subsection{Los blandengues y dragones}

En enero de 1809, luego del motín de Álzaga, el virrey Liniers dispone que la custodia del amotinado y de quienes lo acompañaron en esta insurrección, cabildantes Juan Antonio de Santa Coloma, Olaguer Reynal, Francisco de Neira y Arellanos y Esteban Villanueva fueran custodiados por el cuerpo de Blandengues. Motivaba esta decisión el mayor conocimiento que estas milicias poseían del medio geográfico y de los códigos lingüísticos indígenas. Así queda demostrado en las palabras de Liniers, al enviar oficio al Comandante de Patagones, en atención a la medida tomada:

\footnotetext{
El portador de esta lo será el soldado Blandenguez de esta frontera Josef Manuel Luna a quien he preferido para que la conduzca, asi por su inteligen.cia en el camino q.debe seguir, e idioma de los indios pampas, como porque ya ha ejecutado otra comisión de igual clase con el mejor efecto; $\ldots{ }^{18}$.
}

Brevemente, nos detenemos en analizar sobre los escuadrones de blandengues y dragones - cuerpos de milicias que estaban asentados en el espacio estudiado - su origen, su función y cómo se habían formado en esas capacidades militares. El escuadrón de Blandengues operaba en esa localidad desde 1781 por orden del virrey Vértiz cuando se produce la invasión del cacique Negro.

Félix Azara consideró que los blandengues de «errantes y lanzeros» se «fijaron» en varios puntos de la frontera, siendo en muchos casos el servicio impuesto a ellos «inhumano». Este Capitán de Navío de la Real Armada veía a este cuerpo «como hombres abandonados a su suerte», resaltando de ellos su capacidad de poblar las pampas: «Es muy claro que de los blandengues debe esperarse la población de las pampas; no sólo porque las defienden y aseguran como soldados, sino también porque son pobladores natos y seguros, y lo será su descendencia...» ${ }^{19}$.

${ }^{17}$ Blas Guerrero pertenece a una de las familias colonizadoras llegada en 1784, descendiente de Josef Guerrero, Entraigas, R. El Fuerte de Río Negro, op. cit., pág. 269.

${ }^{18}$ AGN, Sala X, División Colonia, 28-5-06, 1762-1810.

${ }^{19}$ Azara, F. «Diario de un reconocimiento de las guardias y fortines que guarnecen la línea de frontera de Buenos Aires para ensancharle», en: De Angelis, P. Colección de Obras y documentos relativos a la historia antigua y moderna de las Provincias Unidas del Río de la Plata, 2a edición, Tomo V, Buenos Aires: Lajouane Editores, 1910, págs. 80-83. 
Existió una preocupación manifiesta de las autoridades sobre la falta de instrucción práctica y teórica de las subunidades de milicias reclutadas para fortificar la frontera. Ejemplo de ello es el documento del gobernador interino de Paraguay remite por nota al ayudante mayor Don Manuel Bazazabal en la que hace expresa mención a la falta de instrucción, proponiendo un plan de enseñanza: «...en vista de la falta de instrucción que ha notado en estas Milicias y del plan de enseñanza que propone se sirva V.E. resolver lo que sea de su superior agrado» ${ }^{20}$.

Estos cuerpos destinados a la frontera, muchas veces ajenos a sus funciones militares, carecían de la práctica de instrucción y entrenamiento necesario para afianzar un sistema de disciplina, ejerciendo poca respuesta a las órdenes superiores.

En cuanto a los Dragones, Beverina transcribe un documento según el cual el virrey Arredondo había manifestado «la escasa instrucción» de ellos, quienes se comportaban como simples peones de campo ${ }^{21}$.

El virrey Vértiz con el lenguaje propio del Siglo de las Luces, asocia el término de cultura al de civilización, parámetro o criterio para cuantificar el grado de alfabetización de una sociedad. Así el soldado pasa a tener un conjunto de habilidades que permiten valorar y jerarquizar un criterio de evolución: «pervertido en sus costumbres», «carece de prácticas de subordinación y puntualidad y falta de castigo a sus delitos», estando «abandonados al ocio» ${ }^{22}$.

También, y en este mismo orden, en 1807, el Cabildo de Buenos Aires consideraba a los miembros de las milicias como «malos servidores, infames vasallos», haciendo mención a la falta de instrucción de las tropas la que sería confiada a personal veterano de oficiales, sargentos y cabos, quienes constituían las llamadas «asambleas». Por ende, la instrucción quedaba reducida más a la práctica que a la teoría: manejo de arma, formas de organizar columnas, volver al orden en la batalla, saber ensillar.

El poder - en este contexto - descansa en un conjunto de relaciones y prácticas que construyen los oficiales y la tropa a través de capacidades y experiencias objetivas que en muchos casos fracasan por el desconocimiento teórico-profesional de la oficialidad. Este último, contempla la organización de la escolarización y el saber de la institución militar.

Los diferentes proyectos de avance fronterizo analizados con anterioridad en el capítulo I — que se produjeron a partir de 1822 y hasta la fundación de la Fortaleza Protectora Argentina - fueron producto de una política de militarización de la frontera cuyos principales actores pertenecían a los cuerpos de Blandengues, Dragones, Húsares y fuerzas navales que cumplían con el reconocimiento paralelo de las costas y estudios topográficos. Cabe puntualizar en este punto que muchos de estos intentos fracasan ante la falta de organización para los propósitos buscados y el desconocimiento climático y geográfico de la región a urbanizar.

En referencia a la escasa instrucción de las milicias en esta época, Walther, reproduce un capítulo de las memorias del general Paz, quien acentúa este factor, al decir que los militares del país se caracterizan por «la más completa desaplicación, proveniente de la ignorancia de la mayor parte de los jefes del

\footnotetext{
${ }^{20}$ AGN, Sala X, División Colonia, 1762-1810, fecha: 18 de agosto de 1796.

${ }^{21}$ Beverina, J. Op. cit., pág. 238.

${ }^{22}$ Idem, pág. 285.
} 
cuerpo...(mirando) con desdén y hasta con desprecio a un oficial joven que diese mucho valor a la instrucción de otras materias, fuera de aquellas triviales de la profesión» ${ }^{23}$.

El análisis de los sueldo o la paga a la milicia implica además una forma de identificar poder social y económico. Analizado el censo con sus respectivos sueldos se desprende que dentro de la oficialidad de las tropas se consideraban a tenientes, subtenientes y sargentos segundos, cabos primeros y segundos. En menor rango, tambores y soldados.

Los oficiales de Dragones recibían una retribución económica mayor que los de infantería, siendo el salario del negro interprete un poco más bajo (\$6) que el de los peones de la goleta «San Josef» (\$10) y un poco menor que el cabo de infantería encargado de distribución de carne vacuna $(\$ 8)^{24}$.

Garavaglia en su análisis sobre los sueldos de los militares después de 1810, considera que existió vinculación entre status y sueldo antes y después de la profesionalización de la carrera militar ${ }^{25}$. Esto nos permite admitir que en esta sociedad — desde fines del siglo XVIII y hasta la década del cincuenta del siglo siguiente - los actores vinculados a los diferentes cuerpos militares al estar dotados de competencias intelectuales convierte en poderoso no al «estanciero de la frontera» en primera instancia, sino quien se encuentra mejor posicionado en el escalafón del cuerpo o tropa a la que pertenece.

Fernando Barba, en su estudio de pobladores y empleados de Carmen de Patagones, analizado anteriormente, desglosa minuciosamente la relación entre cargos y sueldos, exteriorización económica de lo aseverado con posterioridad por Garavaglia ${ }^{26}$.

Al preguntarnos a qué sectores sociales pertenecían los hombres destinados a las milicias o cargos de menor rango queda develada la resistencia que ofrecieron los cuadros de poder político y económico para su incorporación. Por la Real Orden del 22 de agosto de 1794, los comerciantes de registro y mercaderes de tienda cuyo giro comercial fuera importante, al igual que sus respectivos dependientes, quedaron eximidos de prestar servicios en «milicias regladas o provinciales», a pesar de la necesidad que ellos mismos manifestaban sobre la defensa de su capital y de sus $\operatorname{costas}^{27}$.

\section{Conclusiones parciales}

Como queda explicitado en lo analizado anteriormente podemos anticipar algunas conclusiones parciales:

${ }^{23}$ Walther, J. C. La Conquista del desierto. Sintesis histórica de los principales sucesos ocurridos y operaciones militares realizadas en la Pampa y Patagonia contra los indios. (Años 1527-1885), Tomo I, Buenos Aires, Círculo Militar, Biblioteca del Oficial, 1947, págs. 218-219.

${ }^{24}$ Cfr. Fuente documental de Entraigas, R. A., Op. cit., págs. 268-271.

${ }^{25}$ Garavaglia, J. C. «Ejército y milicia: los campesinos bonaerenses y el peso de las exigencias militares. 18101860», en: Garavaglia, J. C. Construir el Estado, inventar la nación, op. cit., págs. 267-308.

${ }^{26}$ Barba, F. E. «Pobladores y empleados de Carmen de Patagones. 1779-1810», op. cit., págs. 149-171.

${ }^{27}$ Beverina, J. Op. cit., pág. 238. 
La militarización del fuerte de Carmen de Patagones contiene una dinámica dependencia interdiscursiva de sus actores con los saberes científicos, técnicos y prácticos, que genera efectos dentro del contexto del poder y la autoridad, donde el espacio no es ajeno a este fenómeno. La construcción del poder vinculado con las estructuras del saber parece provocar en determinados momentos cierta disolución de jerarquías militares, ante la dependencia de la oficialidad de los sectores subalternos, como lenguaraces, baqueanos y técnicos.

$\checkmark$ El componente social de la milicia que guarnecía las fronteras fortalecen vínculos y uniones familiares que los posicionan como futuros pobladores y una organización regular del espacio físico con la construcción de viviendas de adobe y tejas, modificando la organización urbana.

\section{Militarización y educación en Bahía Blanca}

El carácter propiamente militar de la Fortaleza Protectora Argentina, hizo según sostiene Esteban Rigamonti, que la actividad en el orden educacional fuera prácticamente nula siendo para este autor motivo que retardó el progreso en la frontera hasta 1838, con las primeras gestiones iniciadas por el comandante del fuerte Martiniano Rodríguez ${ }^{28}$. A pesar de esta aseveración, no se ha podido constatar en la documentación analizada en el Archivo Nacional de la Historia ni en el Archivo Histórico Municipal de Bahía Blanca, documento que pruebe la existencia de dicho petitorio.

Analizados los distintos trabajos de carácter histórico que hacen referencia al desarrollo educativo de Bahía Blanca, no existe mención en ellos sobre inquietudes de vecinos o de las milicias asentadas en el fuerte, por establecer una escuela. Todos los estudios históricos educativos anteriormente citados, como Juan P. Ramos, Antonio Salvadores, Antonio Portnoy, Evaristo Iglesias, han identificado la etapa rosista como de atraso cultural-educacional, historiadores contemporáneos, en contraposición como Carlos Newland, Fernando Barba, vieron a este período como el momento de un cambio sustancial en la concepción educacional. El revisionismo histórico argumenta la existencia de una nueva visión educativa, considerando a Sarmiento el principal propagandista de la «leyenda roja», y de la antítesis de «civilización y barbarie y ciudad contra la campaña» ${ }^{29}$.Para Salvatore el castigo ejemplar, por ejemplo era presentado como un mensaje que permitía el imperio de la ley «...que era ante todo un proyecto educativo» ${ }^{30}$. Es decir, que la ley fuese aprehendida por los paisanos.

En la edición «Homenaje de La Nueva Provincia al Primer Centenario de la Fundación de Bahía Blanca», y en coincidencia con otros estudios liberales, «el .los gobiernos anteriores» sino que además clausuró las escuelas dependientes del ministerio de gobierno sostenidas gran parte de ellas por la

\footnotetext{
${ }^{28}$ Rigamonti, E. Antecedentes históricos sobre la ciudad de Bahía Blanca, Publicación de los Amigos de Bahía Blanca, Buenos Aires: Talleres Gráficos de la Sociedad Impresora Latinoamericana, 1950, págs. 153-157.

${ }^{29}$ Irazusta, J. Ensayos históricos, Buenos Aires: Eudeba, 1973, pág. 215.

${ }^{30}$ Salvatore, R. Subalternos, derechos y justicia penal. Ensayos de historia social y cultural argentina. 1829-1940, Barcelona: Gedisa, 2010, pág. 96.
} 
Sociedad de Beneficencia ${ }^{31}$. El anónimo autor de este análisis sostiene que el período rosista «fue marcadamente retardatario» y que no existe documentación sobre la existencia de una escuela en Bahía Blanca durante esta etapa. Indica como probable que los párrocos fueran los encargados de enseñar a la población. Cabe decir, que siguiendo su pensamiento, recién a partir de 1835, con la fundación de la parroquia Nuestra Señora la Merced, existieron actores capaces de transmitir las primeras letras. Contrariamente a su suposición, dice que no hay documentación que pruebe esta inferencia, considerando que la historia educativa local se inicia a partir de 1856.

Alberto Reyna Almandoz, autor de una de las obras más completas sobre educación elemental en Bahía Blanca, sostuvo que «la tiranía destruyó la comenzada obra de progreso e ilustración general». Para este autor, Rosas fue el responsable de retardar las realizaciones rivadavianas en el sur de la provincia $^{32}$.

Lázaro sostiene en la obra de Levene que no existió escuela pública alguna hasta después de la caída de $\operatorname{Rosas}^{33}$.

Esta tardía iniciación de la enseñanza gratuita se explica si se tiene en cuenta que justamente cuando pudo ser factible la creación de una escuela en el distrito, el Gobernador Rosas suprimió todos los establecimientos públicos de enseñanza primaria en la Provincia, por sus conocidos decretos del año 1838, que estuvieron en vigencia hasta 1852.

Si tenemos en cuenta el carácter de fuerte militar que tenía esta población desde su fundación y hasta 1838, podemos inferir que existió una estrecha vinculación entre su evolución educacional y los cuerpos militares.

A diferencia de otras poblaciones fronterizas bonaerenses, como Púan, Guaminí, Carhué, Tres Arroyos, Coronel Suárez, Coronel Pringles donde el impulso educativo estuvo dado por la acción de vecinos, de jueces de paz o de miembros de la iglesia católica, hacia la década del setenta, en esta región del sudoeste la iniciativa partió fundamentalmente de los Comandantes de los Fuertes. En este punto, las variables educativas entre Bahía Blanca y Carmen de Patagones, aspecto que analizaremos más adelante.

El 31 de mayo de 1833, el gobernador Balcarce informaba a la legislatura acerca de la creación de un nuevo cuerpo militar de frontera para guarnecer Bahía Blanca: el Regimiento de Blandengues. Al igual que en Patagones, este cuerpo para apoyar a las poblaciones contra las incursiones indígenas ${ }^{34}$. El origen

${ }^{31}$ Centenario de Bahía Blanca, Homenaje de la Nueva Provincia en el Primer Centenario de la fundación de la ciudad de Bahía Blanca, Bahía Blanca. La Nueva Provincia, 1928, pág. 651.

${ }^{32}$ Reyna Almandoz, A. Bahía Blanca y sus escuelas, Bahía Blanca: Panzini, 1928, págs. 32-34.

${ }^{33}$ Lázaro, J. F. «Bahía Blanca. Origen y evolución política», en: Levene, R. Historia de la Provincia de Buenos Aires y formación de sus pueblos, La Plata: Taller Impresiones Oficiales, 1941, págs. 71-79.

${ }^{34}$ Provincia de Buenos Aires, Mensajes de los gobernadores, Tomo I, 1976, pág. 75. 
de estas milicias había respondido a la práctica de «levas de vagos y mal entretenidos...obstáculo real del adelantamiento del país» ${ }^{35}$.

Según se desprende del reservorio documental, el regimiento de Blandengues conformaba su cuerpo de oficiales, un capitán, tenientes, ayudantes mayores, alférez, trompetas y cabos. En cuanto al regimiento de Dragones con sede en Fuerte Argentino, la plana mayor estaba integrada por un coronel, sargentos mayores, ayudantes mayores y un porta-estandarte ${ }^{36}$. La reglamentación vigente para los integrantes de la milicia, tenía previsto que la instrucción de cabos y sargentos la realizarían los ayudantes del Batallón ${ }^{37}$. Cabe ahora preguntarnos, ¿Qué instrucción o formación educativa tenían estos oficiales? Tal como lo analizamos en el punto anterior, y analizado el reglamento, primaba una instrucción netamente práctica. No podemos ignorar que los oficiales poseían saberes teóricos que conjugaban con el uso de armas, estrategia militar, cuidado de caballos, técnicas para montar y ensillar los mismos. Si la posibilidad de ascenso del oficial estaba vinculada a un examen teórico, implicaba que el mismo estaba alfabetizado.

Pedro Gascone, vecino de Bahía Blanca, narra que en 1833 el pueblo «...era entonces un conjunto de pocos y residía allí una Guarnición para defender el punto contra los salvajes». Según el testimonio de este comerciante francés la población había aumentado notoriamente llegando a más de «tres mil almas» ${ }^{38}$.

Se realizó un análisis comparativo entre el padrón levantado en 1834 en el partido de Bahía Blanca comparando el mismo con el de 1836 para verificar la preeminencia en porcentaje de población de militares por el número de habitantes y población en edad escolar.

\begin{tabular}{|c|c|c|c|c|}
\hline Año & Nro. habitantes & $\begin{array}{c}\text { Población en edad } \\
\text { escolar }\end{array}$ & Militares & $\%$ pobl. militar \\
\hline 1834 & 611 & 163 & 145 & 23,73 \\
\hline 1836 & 1461 & 276 & 986 & 67,49 \\
\hline
\end{tabular}

${ }^{35}$ Prado y Rojas, A. Leyes y decretos, 1877, pág. 279.

${ }^{36}$ AHMMBB, octubre, 25 de 1836.

${ }^{37}$ Reglamento para el Ejercicio y Maniobras de la Caballería. 1834, pág. 1 citado en Comando en Jefe del Ejército, pág. 424.

38 AGN, Colección Andrés Lamas, Legajo 21, «Relación de los vejámenes y violencias ejercidas en mi persona y bienes por las autoridades de Bahía Blanca, en la Provincia de Buenos Aires, y por el Gobierno de esta y de las posteriores arbitrariedades del mismo, de la Comisión Mixta y del señor Cónsul Francés relativamente a mis reclamaciones», Montevideo, 2 de septiembre de 1841, Recopilación y notas a cargo del Dr. Carlos Funes Derieul. 


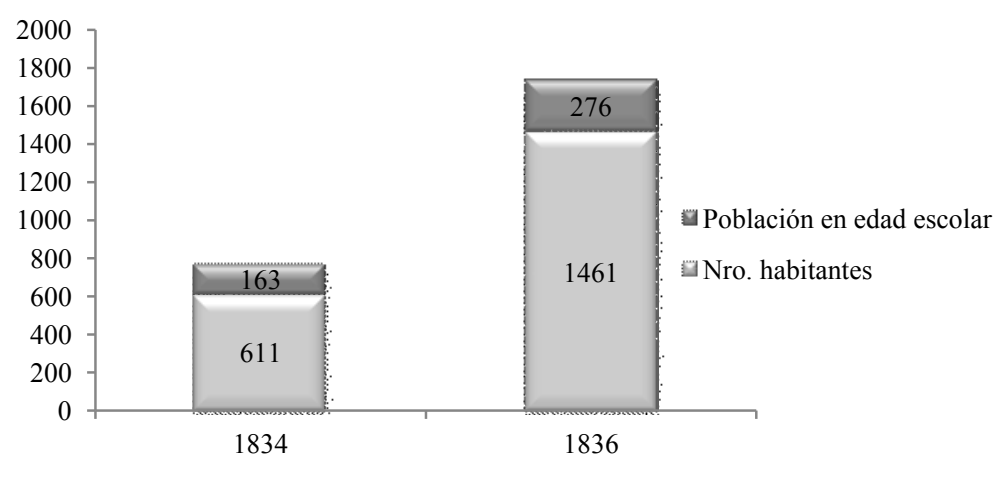

(*)Fuente: AHMBB, Padrones de 1834 y 1836.

El padrón de 1834 revela, además, la existencia de 135 ciudadanos aptos para votar y de 71 hombres enrolados en la infantería de la Guardia Nacional y 84 en la Caballería.

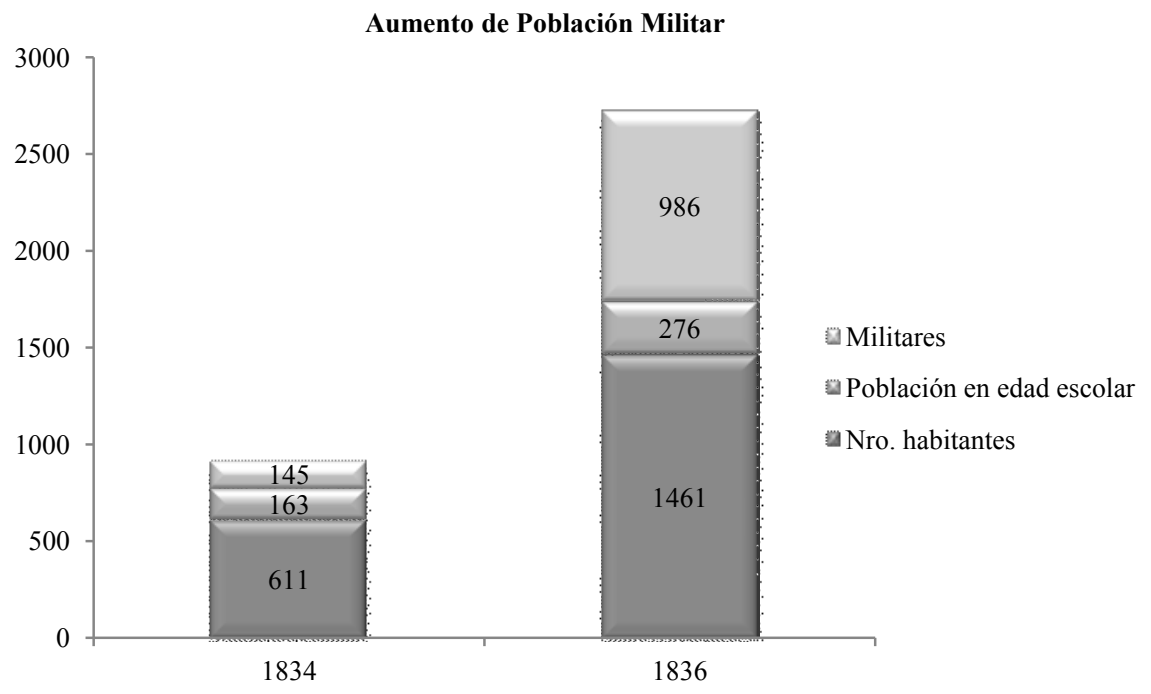

Porcentaje de Población Militar

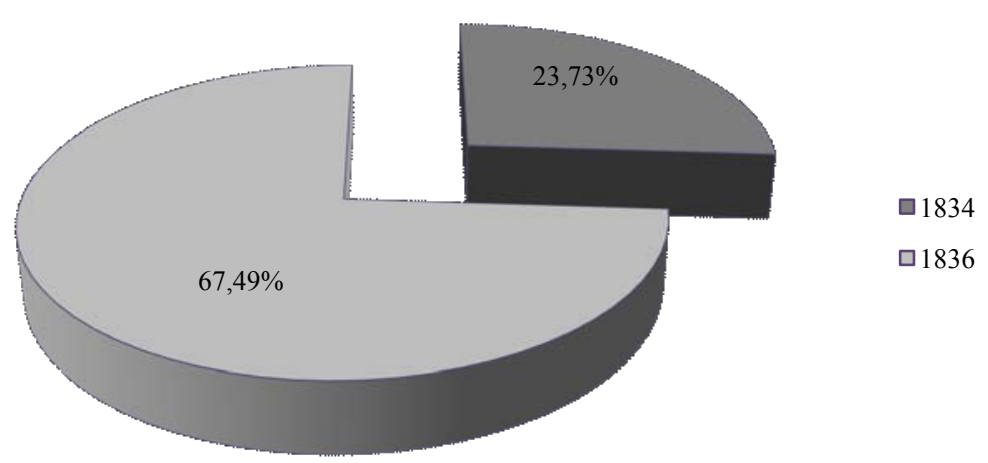


Según reflejan las estadísticas, se produce un aumento sustancial en la población militar del fuerte hacia 1836, imprimiéndole por lo tanto, un carácter particular a esta población en su desarrollo cultural.

La población adquiere características propias: la sociedad se estratifica según el grado militar que ocupa el padre de familia, separando al resto de la población en quinteros o comerciantes. Por otra parte, observamos que también la población militar se estratifica al dividirse en hijos de oficiales e hijos de tropa.

Por lo tanto, si tenemos en cuenta el porcentaje de población en edad escolar, sería probable la manifestación de Rigamonti acerca de la solicitud que habría hecho el coronel Martiniano Rodríguez, para establecer una escuela en el Fuerte.

De acuerdo a la documentación analizada en el Archivo Histórico de Bahía Blanca, se observa que existiría - por el carácter de su escritura-, cierto nivel de alfabetismo en la oficialidad, no así en funcionarios como los Jueces de Paz. Por Decreto del 13 de septiembre de 1834 se crea el juzgado de Paz «... para todo el distrito comprendiendo a la Fortaleza de Bahía Blanca y sus adyacencias» ${ }^{39}$. Esta institución favorecería un avance en el poblamiento territorial y en una mejor administración de la justicia.

Silvia Ratto que realizó uno de los más sólidos y precisos estudios sobre la estructura militar de la campaña, ha demostrado que en los fuertes Federación, Tapalqué, 25 de Mayo y Bahía Blanca había una fuerza armada de unos 4000 hombres, 904 milicianos y 2360 indígenas. La fuerza del ejército era — para esta autora- decisiva en algunos puntos como Bahía Blanca ${ }^{40}$. Tomando los números de Ratto, observamos que el $39 \%$ de esas milicias estaban asentadas en este punto, considerando de suma importancia a fuerte Argentino, sito a pocos kilómetros de la antigua fortaleza.

En cuanto a Bahía Blanca, los padrones y del cantón de Bahía Blanca de 1835, son fuente de información de distintos aspectos de las milicias asentadas en este espacio del sudoeste bonaerense. Como medio ilustrativo, acompañamos algunos ejemplos:

\section{Nómina de oficiales}

\begin{tabular}{|c|c|c|c|c|c|c|c|}
\hline Clases & Nombre & Madres & Mujeres & $\begin{array}{c}\text { Hijos } \\
\text { varones }\end{array}$ & Chinas & $\begin{array}{c}\text { Indios } \\
\text { varones }\end{array}$ & Total \\
\hline Capitán & Francisco Palao & & & & & & \\
\hline Cura Vicario & Juan Biggio & & & & & & \\
\hline Maestro armero & Francisco Chacón & & & & & & \\
\hline $\begin{array}{l}\text { Ayudante } \\
\text { cirujano }\end{array}$ & Ramón Fresno & & & & & & \\
\hline
\end{tabular}

Fuente: Padrón del 14 de marzo de 1836, pág. 11 .

\footnotetext{
${ }^{39}$ Decreto de creación del Juzgado de Paz de Bahía Blanca, AHMMBB.

${ }^{40}$ Cfr. Ratto, S. M. La frontera bonaerense (1810-1828): espacio de conflicto, negociación y conveniencia, La Plata, Archivo Histórico de la Provincia de Buenos Aires «Dr.Ricardo Levene», 2003.

Ratto, S. «Allá lejos y hace tiempo. El fuerte del Carmen en la primera mitad del siglo XIX», ojs.fchst.unlpamp.edu.ar/ojs/index.php/quintosol/article/view/733/661
} 
Fuerte Argentino. Tropas de Artillería en Fuerte Argentino

\begin{tabular}{|c|c|c|c|c|}
\hline Clases & Nombre & Mujeres & Hijos & Total \\
\hline Comandante & Juan Francisco Dìaz & 1 & 2 & $3 *$ hay criadas indígenas \\
\hline Sargento. & Pedro Sánchez & 1. & 1 & 2. \\
\hline Cabo. & José....(i).. & 1. & 3 & 4 \\
\hline Artillero & Lucas Bramofi & 1 & 2 & 3 \\
\hline Totales & & 4 & 8 & 12 \\
\hline
\end{tabular}

Fuente: Padrón del 14 de marzo de 1836, pág. 12.

Plana mayor del Regimiento de Dragones

\begin{tabular}{|c|c|c|c|c|c|c|c|}
\hline Clases & Nombre & Mujeres & $\begin{array}{c}\text { Hijos } \\
\text { Varones }\end{array}$ & $\begin{array}{c}\text { Hijas } \\
\text { mujeres }\end{array}$ & $\begin{array}{l}\text { Chinas } \\
\text { mujeres }\end{array}$ & Indios & Total \\
\hline Coronel & Martiniano Rodríguez & 1 & 1 & 1 & 3 & 2 & 7 \\
\hline Sargento & Jose Luis Palavecino & 1 & 1 & 1 & 1 & & 4 \\
\hline Sargento. & Mariano Figueredo & 1 & & & & 1 & 2 \\
\hline Ayudante Mayor & Manuel Collaos & 1 & 3 & 1 & 1 & 1 & 7 \\
\hline Ayudante Mayor & Juan López & 1 & 1 & 2 & & & 4 \\
\hline Porta Estandarte & Juan Isidoro Molina & $\therefore$ & & -- & - & --- & -- \\
\hline Porta Estandarte & Manuel Masa & & & & & & - \\
\hline Individuo de tropa & & 1 & 1 & 1 & ----- & ------ & 3 \\
\hline Total & & 6 & 7 & 5 & 5 & 4 & 27 \\
\hline
\end{tabular}

Firmado por José Luis Palavecino.

Fuente: Padrón, Fuerte Argentino, octubre, 25 de 1836, pág. 14.

Estos padrones son una rica fuente de información que permiten examinar la composición sociocultural y clasificatoria de cada cuerpo de milicias. Limitando el campo de observación en forma más refinada, permite distinguir una cartografía diferente de lo social: la estratificación de cada cuerpo, los nominación de grupos subalternos y de «los de abajo», las primeras familias y una constitución que en lo microanalítico devela la existencia dentro de los cuerpos de frontera de mujeres cuyos nombres las ubican en primeras pobladoras y un contexto de control social de los cuadros superiores que incorporaba formas de servidumbre indígenas en las chinas y los indios.

Otro de los aspectos que pudimos identificar en el análisis de los padrones y del Cantón de Bahía que conforman 49 fojas, es que por cada planilla que se elaboraba, existía un responsable que la firmaba. De la misma se desprende quien ostentaba el mayor cargo jerárquico en cada cuerpo era quien firmaba la planilla. Esta cuestión, que no es menor, permite identificar un conocimiento de la lectoescritura, bien incuestionable para medir la escolarización de los cuadros superiores de la tropa. Podemos inducir, por tanto, que existe una vinculación de los oficiales de mayor rango, que elaboran y firman las planillas, que le facilitan autonomía para su construcción, con su grado de alfabetización que trasciende en muchos casos en los rasgos de sus propias firmas. 


\section{Darwin: la mirada del naturalista sobre la milicia de Bahía Blanca}

Charles Darwin, anticipando la futura disyuntiva entre «civilización y barbarie», encuentra en los milicianos en la costa del Colorado, la «barbarie fronteriza»: "Casi todas las tropas eran de caballería, y me inclino a creer que jamás se reclutó en el pasado un ejército semejante de villanos y seudobandidos» ${ }^{41}$.

Parafraseando a François Perus, podemos afirmar en esta instancia que «el espacio-tiempo fronterizo así bosquejado sugiere la presencia de la "barbarie" en la "civilización" y la "civilización" en la "barbarie", aún cuando esta compenetración mutua sea común e inestable»" ${ }^{42}$.

Darwin en su esfuerzo por el acopio de datos y huellas heterogéneas de la cultura de la pampa bonaerense, formula enunciados propios de su profesión de naturalista, marcando la diferencia entre la figura del oficial con la del resto de la tropa. Ese «hombre alto de uniforme», que se presentaba como Comandante del Fuerte, es quien menos desconfía de la presencia de estos ingleses, quienes se habían presentado como naturalistas aumentando las dudas de «un viejo mayor», quien «hizo al Comandante toda suerte de advertencias a nuestro respecto». A nivel discursivo, Darwin detalla meticulosamente la «ignorancia» de estas milicias y «desconfianzą̇ hacia lo extraño:

\footnotetext{
Después supimos que las sospechas del viejo mayor se habían acrecentado con la explicación de Harris acerca de la ocupación de Mr. Darwin. El término «naturalista» era desconocido allí, y al definirlo Mr. Harris como «un hombre que todo lo sabe», no hubo ya medio de que se calmaran las cavilaciones.
}

El comportamiento del soldado hacia Darwin es el mecanismo propio de quien teme a lo desconocido, relación propia del hombre que no es poseedor del saber ni del lenguaje de los extranjeros y su reacción —más que desconfianza — es el temor por lo mismo que él ignora.

Darwin califica al ejército de Rosas «como una partida de bandoleros...casi todos tienen sangre negra, india, española en las venas», considerando que los hombre de tal origen «rara vez tienen buena catadura». En su relato el naturalista inglés pondrá de manifiesto la forma «altanera» con que fue tratado por miembros de la tropa ${ }^{43}$.

\section{Conclusiones parciales}

Como primera aproximación, observamos algunas diferencias entre el proceso de militarización y su vinculación de escolaridad con Patagones en los siguientes ítems:

\footnotetext{
${ }^{41}$ Darwin, C. Op. cit., págs. 106-107.

42 Perus, F. «Orientalismo y occidentalismo», Cuadernos Americanos. Nueva Época, n. ${ }^{139}$, México, UNAM, 2012, págs. 105-115.

${ }^{43}$ Darwin, C. Mi viaje alrededor del mundo, Tomo I, Valencia: Editorial Sampere, s/f, págs. 76-79.
} 
Un porcentaje mayor de población militar por sobre la civil genera que la escolarización cumple una función de regulación social y de control del poder, ante la existencia de «hijos de la guarnición»e «hijos del regimiento de Blandengues».

$\checkmark$ La conformación de los grupos familiares estaba determinado por el grado o rango militar que ocupaba el padre de familia, nos permite descubrir el dominio del saber en cuanto su nivel de descripción de los cuadros militares y familias a su cargo.

Existió por parte de la oficialidad una categorización como educadores asistemáticos para esposas e hijos, otorgando peculiaridades verticalistas a la fisonomía social de la zona. A diferencia de Patagones existen escasos vínculos con sectores subalternos o relaciones de comunicación con otros grupos, quienes - a lo sumo - ocupan lugar como servidumbre para los oficiales de mayor jerarquía.

\section{Los comandantes de frontera y su incidencia en la educación. Vínculos con maestros y vecinos}

Los comandantes de frontera adquirieron un papel protagónico en lo que respecta a la organización y creación de las primeras instituciones educativas formales en Carmen de Patagones, en primera instancia, y más tarde, en Bahía Blanca. Este protagonismo les permitió el control político, militar, cultural y educativo de este espacio fronterizo.

En este espacio — siguiendo a Hosftede y su teoría de las dimensiones culturales - la dimensión «distancia de poder», significa el respeto y diferencia existente entre aquellos que se encuentran en una posición superior y quienes están en un estrato social diferente ${ }^{44}$.

Las culturas con alta distancia de poder valoran la jerarquía social y el respeto a la autoridad. Existen algunas variables socio métricas que nos permiten visualizar que aquellos actores que cumplen papeles protagónicos en regiones fronterizas, con diferentes grados de formación profesional y educativa, logran posicionarse en otros estamentos generando aún más los grados diferenciales entre unos y otros ${ }^{45}$.

En este punto, es importante tener en cuenta que el comandante era quien ejercía el control militar y político, quien se percibe como individuo o clase dominante, existiendo vínculos con gran parte de vecindad de subalternidad, concepto que utilizamos basándonos en Ricardo Salvatore. Estas relaciones de dominación-subordinación se generan en una sociedad en base a género, raza, etnia, edad, posición social y educación ${ }^{46}$.

Las llamadas «comandancias» presentaban características peculiares en cuanto a su construcción y disposición. Pero, en lo que se refiere al tema central que nos ocupa, en ellas existía un lugar específico,

${ }^{44}$ Hofstede, G. H. Culture `onsequences, California: Sage, 1980, pág. 224.

${ }^{45}$ Cfr. Páez Rovira; Zubieta, E. y Aguilera Torres Identidad cultural, aculturación y adaptación de los inmigrantes Latinoamericanos en el País Vasco, San Sebastián, Centro Cultural Chileno Pablo Neruda, 2000, pág.17.

${ }^{46}$ Salvatore, R. Subalternos, derechos y justicia penal. Ensayos de Historia Social y cultural argentina (18291940), Barcelona: Gedisa, 2010, pág.42. 
previamente determinado, para «oficios religiosos y para la escuela» ${ }^{47}$. La disminución de presupuesto oficial para el sostenimiento de escuelas de campaña a partir del interinato de Vicente López (1827) y la dependencia de las mismas de la Universidad de Buenos Aires (1828), permite inferir que existirá una reorganización tanto en la construcción de sus edificios, como una mayor autonomía de la milicia.

A partir de 1823, y luego frente al conflicto bélico con Brasil, el gobierno establece nuevas reglas en cuanto a la formación de los cadetes para oficiales del Ejército. A partir de este momento, los requisitos como la pertenencia a la nobleza, son modificados, buscando que los nuevos miembros de ejercito fueran hijos de soldados de la Independencia, respetuosos de las leyes de país, certificado de maestro que atestiguara que sabía leer y escribir, conocimientos de aritmética, física y química, doctrina cristiana, gozar de buena conducta y méritos propios de la función a ejercer. Esta formación se completaba con dos años de dibujo, de idiomas inglés y francés, esgrima y manejo de armas ${ }^{48}$. Los alumnos asistirían una vez por semana a una academia donde un oficial los preparaba en táctica, legislación e historia militar. Al término del curso eran examinados por un juri compuesto por cuatro jefes de Ejército y tres profesores nombrados por el Gobierno. Este juri determinada la continuación de algunos alumnos seleccionados para un segundo curso. Para la difícil cobertura de cargos en las zonas de frontera, se procedía con la aplicación de la Ley de Milicias de diciembre de 1823 que mantuvo en vigencia hasta 1872. Esta ley entra en vigencia en 1824 permitiendo el enrolamiento de hombres a través de una Comisión formada por un Juez de Paz, un Teniente y un Oficial nombrado por la Inspección General.

Los distintos requerimientos en la formación de los oficiales del ejército de campaña, nos permite visualizar las potencialidades que influenciaban en su adaptación según los espacios a los que eran destinados. Desde un «espacio de poder» quienes ocupan los cargos públicos, intentan conducir a quienes no los tienen, de acuerdo a su propio proyecto político. Esto les permitirá acceder a cargos políticos relevantes logrando un ejercicio efectivo del poder, mediante un sistema de relaciones de obediencia y mando, que les facilitará el control general de la sociedad ${ }^{49}$.

Como estereotipos por su compromiso en la generación de iniciativas educativas en los centros urbanos que dirigían, daremos algunos ejemplos, basados exclusivamente en documentación inédita, especialmente de Carmen de Patagones.

${ }^{47}$ Archivo Histórico de la Provincia de Buenos Aires, Documentos del Congreso General Constituyente de 18241827, Tomo XIII, La Plata, 1949, pág. 23.

${ }^{48}$ Domínguez, E. Colección de Leyes y Decretos Militares concernientes al Ejército y Armada de la República Argentina.1810-1896, Tomo I, Buenos Aires: Compañía Sud-Americana de Billetes de Banco, 1898-1913, pág. 349.

${ }^{49}$ Cfr. González de Martínez, M. «Elite social, universidad y dirigencia», Studia, Publicación de la Cátedra de Historia del Pensamiento y Cultura argentina, Córdoba, Universidad de Córdoba, 1994, pág. 40. 


\subsection{Coronel José Gabriel de la Oyuela}

La lectura de las comunicaciones de algunos comandantes nos permite trabajar concretamente — según los principios Foucault - sobre el saber de un sujeto, es decir, el espacio en que un sujeto puede tomar posición para hablar de los objetos de que trata en su discurso ${ }^{50}$. Estos archivos permiten observar la transformación de los enunciados, y por ende, los principios ideológicos que los trascienden.

Oyuela, cumplió funciones como comandante de Patagones desde marzo de 1821 hasta no-viembre de 1823. Participó en la campaña de Brasil, siendo designado nuevamente Comandante político y militar de Patagones en 1827.

El conjunto de enunciados de sus comunicaciones y petitorios permite registrar en la ela-boración teórica su adhesión al reformismo rivadaviano en la promoción y fomento de la educación pública, su reglamentación y ordenamiento y su articulación con una serie de acon-tecimientos sucesivos, que lo vinculan con los sectores ilustrados o «intelectuales» de la población ${ }^{51}$.

En consonancia con la política económica impulsada por el Ministro de Hacienda de Rivadavia, con una política liberal — como sostiene Cuccorese - con una rara mezcla de mercantilismo y liberalismo indicativo de un tiempo de transición, Oyuela procura mejorar las comunicaciones marítimas y fluviales, el perfeccionamiento de los sistemas de labranza y la incorporación de inmigrantes portugueses:

El comandante político y militar de Patagones tiene el honor de hacer presente al Señor Ministro Sec.de gobn. Que por noticias particulares...han llegado a Buenos Aires muchos portugueses a establecimientos rurales. Como siempre conserva esta Comandancia la esperanza de hacer producir Viñas en este país no puede contenerse en suplicar al Sor.Ministro por la remisión de veinte o treinta portugueses, si es posible que sean de Oporto ó de lugares donde se fabrica Vino a quienes se les dará lo prometido pa. Que vengan a establecerse en la labranza ${ }^{52}$.

Oyuela, manifiesta al Ministro, que por inacción del Diputado José María Roxas y Patrón, el pueblo se encontraba en inmerso en un marcado atraso. No obstante, este diputado porteño mantiene una correlación funcional con la burguesía de la ciudad de Buenos Aires, asumiendo su cargo aunque resulta evidente el desconocimiento geográfico y cultural del espacio al cual ha sido designado. El pueblo se hallaba inmerso en un marcado atraso. Cabe señalar que Roxas y Patrón fue designado diputado por Patagones en diciembre de 1821 para representar a Patagones en la Legislatura Bonaerense ${ }^{53}$

${ }^{50}$ Foucault, M. La Arqueología del saber, op.cit., págs. 306-307. También es citado este autor por Goldman N. El discurso como objeto de la historia. El discurso político de Mariano Moreno, Buenos Aires: Hachette, 1989, pág. 68.

${ }^{51}$ Cfr. García Enciso, I. J. La gesta de patagones, Buenos Aires: Eudeba, 1977, pág. 26. Según este autor la población era de 471 habitantes, de los cuales 278 eran hombres y 193 mujeres.

${ }^{52}$ AGN, Sala X, C13, 30 de enero de 1823.

${ }^{53}$ Levene, R. Historia de la provincia de Buenos Aires y formación de sus pueblos, Tomo II, op. cit., pág. 507. Según se desprende de los Acuerdos de la Honorable Junta de Representantes de 1822, el 3 de mayo de 1822 , 
Enrique Barba ubica a este diputado como un «unitario hasta 1828» y partidario de Manuel José García $^{54}$. En 1826, Roxas y Patrón, había sido designado representante por la capital del Congreso Constituyente de las Provincias Unidas, no encontrando documentación que avale acciones a favor del poblado de Patagones ${ }^{55}$.En este punto podemos colegir que pudo haber existido cierta inacción por parte del Diputado según lo esperado por el comandante político-militar del poblado, como consecuencia de ser extraño a Patagones, a quien responsabiliza del «atraso» del pueblo.

En este contexto histórico se plantea la lógica tensión entre el poder político y el militar, que como sostiene Noemí Goldman quedan al descubierto en los debates constitucionales de 1824-1827, que demuestra concepciones divergentes de «nación» ${ }^{56}$. Aunque este caso particular traduce la diversidad política que presenta el espacio bonaerense y la distancia del poder central al que hemos hecho referencia.

El estudio de Marcela Ternavasio, muestra que Patagones recién conformará una unidad política como la Sección XIII en 1830 según se desprende del mapa de la Pprovincia de Buenos Aires realizado por el Departamento Topográfico en 1830. Como afirma esta autora, las prácticas electorales que corresponden a este período, demuestran el surgimiento de actores intermediarios, que sin pertenecer a la elite dirigente, logran afianzar cierto control político para zonas de frontera ${ }^{57}$.

En diciembre de 1822, Oyuela plantea a Rivadavia la cuestión de urgencia de cobertura del cargo de maestro de escuela para el pueblo al igual que la designación de un facultativo:

...que siendo tan necesario una persona que se haga cargo de esta escuela se presenta la ocasión de suplicar al Exmo.Gobierno quiera hacer extender el título a favor de Dn.Agustín Muñoz que se dispone a benir (sic) con su familia. La suficiente idoneidad y buenas costumbres que se conocen en este sugeto (sic) con los meritos que deben caber p.a. el cargo de educación.

Este individuo tendrá el favor de presentarse al Señor Ministro implorando se le conceda la asignación de Maestro de Escuela con concepto a la distancia en que se halla este pueblo y se le proporcione la benida (sic) en uno de los buques que vienen de correos.

dice: «seleyó eloficio deremision dela acta y escrutinio delaeleccion de Representat.te.para el pueblo de Patagones hecha enlapersona deD.donJose Maria Roxas pa.elpueblo de Patagones...(sic)», folio 5.

${ }^{54}$ Barba, E. M. Unitarismo, federalismo, rosismo, Buenos Aires: Ediciones Pannedille, 1972, pág. 42.

${ }^{55}$ Documentos del Congreso General Constituyente de 1824-1827, Publicaciones del Archivo Histórico de la Provincia de Buenos Aires, La Plata: Impresiones Oficiales, 1949, «Acta de escrutinio de la elección de diputados al Congreso Constituyente», 8 de junio de 1826, Rojas y Patrón es designado con 3163 votos como representante por la capital de las Provincias Unidas, págs. 197-198.

${ }^{56}$ Goldman, N. «Revolución, nación y constitución en el Río de la Plata: léxicos, discursos y prácticas políticas (1810-1830)», Anuario del IEHS «Prof. Juan C.Grosso», n. ${ }^{\circ}$ 12,Tandil, UNCPBA, págs. 101-107.

${ }^{57}$ Ternavasio, M. «Nuevo régimen representativo y expansión de la frontera política. Las elecciones en el Estado de Buenos Aires: 1820-1840», en: Annino, A. (coord.) Historia de las elecciones en Iberoamérica, siglo XIX. De la formación del espacio político nacional, México: Fondo de Cultura Económica. 
También el Comandante suplica al Señor Ministro por la remisión de un facultativo con la relación de las medicinas que ya se han pedido. El pueblo ha quedado desamparado por el permiso superior que obtuvo Dn. Celedonio Fuentes ${ }^{58}$.

Habermas da dos razones que nos facilita la interpretación discursiva de De la Oyuela: primero, la visión del mundo cuando realiza una afirmación sobre los intereses del mismo, cuya historia está atravesada por una realidad de espacio y contexto, en este caso donde funcionaría la escuela ${ }^{59}$. Segundo, el «pluralismo cultural» del comandante quien percibe la singularidad de Patagones, a diferencia de la interpretación que dan a la misma las autoridades del poder central. El pueblo requiere un maestro con familia, razón que impediría el desarraigo o un posible abandono del cargo. Por otra parte, un mejor sistema de salud mejoraría desigualdades de sus subordinados y de los vecinos en general.

En otro documento que firman Antonio Fernández, Francisco Rivero y Cosme Argerich, se acompaña la lista de medicinas que llevaría el cirujano enviado. En esta relación consta de ungüentos, emplastos, aceites, bálsamos, espíritus, raíces, píldoras, tinturas, flores, sales y extractos ${ }^{60}$. Patagones, siguiendo palabras de Biedma, había sufrido el abandono de su salud pública al no contar con el auxilio de «un hombre de ciencia».

La reiteración de este tipo de petitorios por parte del comandante, junto a la solicitud que las notas fueran enviadas directamente al rector de la Universidad, autoridad independiente encargada de las escuelas de primeras letras constituyen indicios de la búsqueda por allanar trabas burocráticas que normalmente implicaban los nombramientos para estos espacios lejanos ${ }^{61}$.

Podemos afirmar aquí, siguiendo el principio de nuestro análisis en el capítulo I, que en un estudio histórico cultural, no podemos dejar de resaltar los sistemas de conocimiento de determinados actores sociales. En este caso, los Comandantes imponen experiencias que facilitan el progreso de una población a través de la educación y de la salud.

En el análisis discursivo del Reglamento de Escuelas de Primeras Letras de Patagones, en el capítulo I.4, queda evidenciado el protagonismo del comandante y el ascenso de un grupo social en relación con el resto de la población, reforzando elementos de auto representación colectiva. Su superioridad estaba dada por la posesión de saberes y el control monopólico de cargos locales: Oyuela y vecinos ilustrados como Manuel Álvarez, Andrés Paz y Ambrosio Mitre, este último según palabras de Biedma fue quien dio las primeras lecciones como maestro a su hijo Bartolomé ${ }^{62}$.

En 1827, luego de la campaña con Brasil, de la Oyuela es designado nuevamente comandante de Patagones. Al tomar conocimiento de la designación de Juan José Viamonte como Gobernador y Capitán General de la provincia, luego del Pacto de Barracas, se dirige al ministro de Gobierno dando cuenta cómo informó al pueblo de Patagones sobre este cambio de gobierno:

${ }^{58}$ AGN, Sala X, C13, n. ${ }^{\text {2 } 2,29 ~ d e ~ d i c i e m b r e ~ d e ~} 1822$.

${ }^{59}$ Cfr. Habermas, J. La ética del discurso y la cuestión de la verdad, Buenos Aires: Paidós, 2006, págs. 22-23.

${ }^{60}$ AGN, Sala X, C13, n. ${ }^{\circ}$ 2, 2 de febrero de 1823.

${ }^{61}$ AGN, S.10, C13 A8, N3.

${ }^{62}$ Biedma, J. J. Bartolomé Mitre. 1821-26 de junio-1921, Buenos Aires: Rosso Talleres Gráficos, 1921, pág. 5. 
El Cmdte. A fin de dar este acto toda la solemnidad posible dispuso se reuniera el vecindario ayer después de la misa en donde se lo instruyó de este acontecimiento con la lectura de ley documentos que se acompañaban, y puede asegurar el Sr. Ministro q.al Cmdte. No le es dado aplicar la emoción que causó a estos habitantes que le reconocieron con el mayor júbilo, concluyendo el acto con la salva de 21 cañonazos, replique de campanas y a la noche iluminación ${ }^{63}$.

De este documento se puede extraer algunas conclusiones que permiten identificar formas de sociabilidad coordinadas por el comandante del Fuerte, quien a través de la lectura daba parte de las novedades con información sobre la situación política de la provincia de Buenos Aires ${ }^{64}$. Queda al descubierto el estado emocional de la población y diferentes formas de representación en un proceso de comunicación casi escénica, donde están presentes prácticas militares (cañonazos), religiosas (replique de campanas) y teatrales (iluminación). La categoría de vecino parece adquirir en este acto, una relación de mayor proximidad frente a las autoridades jurisdiccionales y coparticipes de la vida política bonaerense.

Dentro del marco de las reformas judiciales que se generan a partir de 1821, los comandantes político militares, también tendrán un papel preeminente en la designación o postulación de vecinos para en esta nueva frontera en las ternas de jueces de Paz. En el caso específico de Oyuela, en su breve segundo mandato solicita la designación de un vecino, que conformaba el círculo con quienes mantenía apoyo a su gestión y mejor administración del asentamiento ${ }^{65}$.

...el Comandante...haciéndole presente que debiendo concluir el actual Juez de Paz en ejercicio en sus funciones en este presente año se hace el más grato deber en proponer al vecino D. José Benito Crespo para que desempeñe aquel cargo...

Las distinguidas calidades que adornan la persona del Señor Crespo obligan quiera interponer una respuesta afin $(\mathrm{Sic})$ de que favorezca la aprobación ${ }^{66}$.

Siguiendo el pensamiento de Fradkin, existió una intención política entre las décadas de 1780 y 1820 que procuró reducir la población rural dispersa y la indujo a vivir en poblados, donde tuvieran sus sedes las estructuras del poder institucional. La distinción les permitió que se transformaran en pueblos de cabecera, como fue el caso de Patagones que en 1821 tendrá la designación de un Alcalde de la

${ }^{63}$ AGN, Sala X, C13, n. ${ }^{\circ}$ 2, Patagones, 12 de octubre de 1829.

${ }^{64}$ Cfr. González Bernaldo, P. «La nación como sociabilidad», Imaginar la nación. Cuadernos de Historia Latinoamericana, n. ${ }^{\circ}$ 2, 1994, págs. 179-213. Gonzalez Bernaldo, P. «Sociabilidad, espacio urbano y politización», en: Sábato, H. y Lettieri, A. (comps.) La vida política en la Argentina del siglo XIX. Armas, votos y voces, Buenos Aires: Fondo de Cultura Económica, 2003, págs. 193-202.

${ }^{65}$ Ratto, S. «Allá lejos y hace tiempo. El Fuerte de Patagones en la primera mitad del siglo XIX», Quinto Sol, n. ${ }^{\circ}$ 12, enero/diciembre, Santa Rosa, 2008, versión on line.

${ }^{66}$ AGN, Sala X, C13, n. ${ }^{\circ}$ 2, 16 de octubre de 1829. 
Hermandad $^{67}$. La designación de primer Alcalde recaerá en un distinguido vecino Juan José Rial, decisión que toma Oyuela luego de un temporal de viento y lluvia en 1821.

Además, procurará la remodelación del fuerte y de las casas de algunos habitantes afectados por el efecto climático, lleva a Biedma a decir:

Hasta entonces la autoridad del Comandante militar había sido exclusiva y absoluta: no contaba el pueblo con un tribunal de carácter civil donde dilucidar sus querellas o garantizar sus derechos... Oyuela dio la primera demostración de su celo, reuniendo la parte más distinguida del vecindario...invitóle a elegir un Alcalde...Recayó la elección unánime en el meritorio vecino Juan José Rial ${ }^{68}$.

Las palabras de Biedma indican una reflexión sobre el poder político, la educación y la centralidad que adquiere una nueva vecindad que está vinculada desde el punto de vista social a caracteres que consisten en maneras de obrar, de pensar y sentir, que tienen como sostiene Durkheim, un poder coactivo, que trasciende la individualidad ${ }^{69}$.

La esposa de Rial fue una de las primeras educadoras lo cual confirma un hecho social. La educación impone maneras de vivir, sentir y obrar, que no son espontáneas. Existe un orden de hechos históricos que fortalecen el prestigio social y político de este Comandante para los vecinos, sumado a la legitimidad que le otorgaba su formación y educación.

A pesar de ser legos, y no recibir remuneración, los jueces de paz, eran elegidos entre los vecinos distinguidos de la población ya sea por su actuación militar, por su origen, por su educación. Crespo reunía todos los requisitos de vecindad que se exigía para ocupar este cargo: era uno de los descendientes de las familias de los primeros colonos de Patagones sumado a que lo habilitaba para ser ciudadano la calidad de hombre libre, ser natural americano con actividad lícita y domicilio establecido. A ello se refiere Oyuela al asegurar «las distinguidas calidades» de Crespo. En 1824 el alcalde se convierte en juez de Paz, manteniendo cierta alternancia y conflictos de vecinos en este período y hasta el segundo gobierno de Rosas, cuando se produce cierta estabilidad institucional tal como sostiene Ratto.

\subsection{Comandante Martín Paulino Lacarra y Toledo}

Martín Paulino Lacarra y Toledo fue el sucesor de Oyuela, teniendo una transición político militar más compleja, que le impidió mayores concreciones educativo-culturales que su antecesor.

Según lo hace constar García Enciso, este militar traía una brillante foja de servicios, actuando en los combates producidos por invasiones inglesas (1806-1807), alcanzando el grado de capitán del regimiento de Granaderos, participando en la lucha con los portugueses en la Banda Oriental.

\footnotetext{
${ }^{67}$ Cfr. Fradkin, R. O. (comp.) op. cit., págs. 42-43.

${ }^{68}$ Biedma, J. J. op. cit., pág. 463.

${ }^{69}$ Durkheim, E. Las reglas del método sociológico, México, Coyoacán, 1994, pág. 26.
} 
Lacarra, durante su gestión, tuvo que enfrentar el conflicto y la invasión del imperio de Brasil, que lo encuentra en un estado de debilidad no solo militar sino también en sus relaciones con los vecinos «ilustrados» que — en otro momento - habían acompañado la acción de la Oyuela. La oposición de vecinos como Fernando Alfaro, Agustín Murguiondo, Mateo Dupin, liderados - fundamentalmentepor Ambrosio Mitre, constituyó uno de sus grandes desafíos en la gestión de Lacarra. Este último vecino en su cargo de tesorero, había sido sumariado y amonestado por el gobierno ante la impresión de billetes en Buenos Aires en $1824^{70}$. De acuerdo al análisis documental realizado, Mitre continúa presentado su libro de entradas y salidas de Patagones en los meses de octubre y noviembre de 1826.

Para Barba la guerra con Brasil puso al descubierto las costas desde Ensenada a Patagones, por ello el comandante logró, mediante la celebración de un tratado, la conservación de la paz con los indígenas, poniendo a su vez de esta manera a cubierto el puerto de la Bahía Blanca ${ }^{71}$.

Desde el punto de vista social, el conflicto con el imperio de Brasil generó un indudable fortalecimiento del poder vecinal, que acelera un clima donde las emociones de los vecinos y de las tropas actúan con mayor complejidad, en respuesta a la autoridad del Comandante. La distancia e incomunicación con el poder de Buenos Aires, obliga a Lacarra a recurrir a la intermediación de un vecino «ilustre», don Juan Andrés Gelly Obes ${ }^{72}$. La intermediación de Gelly y Obes demuestra la necesidad de Lacarra de contar con un asesoramiento jurídico en los fundamentos que le permitieran su permanencia en el cargo.

A pesar de estos conflictos internos que tuvo que sortear, Lacarra, decide la construcción de un edificio escolar. Este comandante hace fabricar en el verano de 1827:

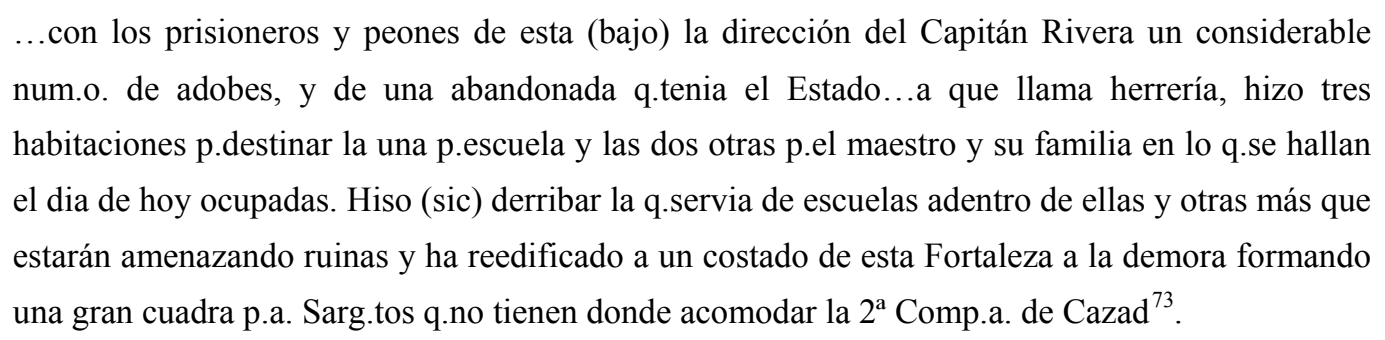

De este documento se desprende que la construcción de edificio escolar cumpliría la función de albergue del maestro y con aposentos para su familia. La cercanía del Fuerte y de la edificación dispuesta para la milicia, visibilizarían de cánones disciplinarios educativos de la época. La construcción

\footnotetext{
${ }^{70}$ Cfr. García Enciso, I. op. cit., pág. 29.

${ }^{71}$ Barba, F. op. cit., pág. 80.

${ }^{72}$ Este distinguido vecino era el padre del general Juan Andrés Gelly y Obes. Abogado, nacido en Paraguay, había cursado sus estudios en el Colegio de San Carlos, diplomándose como Jurisconsulto. En 1826, fue comisionado para conducir a Patagones a varios prisioneros de Guerra. Participó como secretario del Ejército en la campaña con Brasil y en 1828 se manifestó partidario del General Paz.

${ }^{73}$ AGN, Sala X, C13, n. ${ }^{\circ}$ 2, enero 27 de 1827.
} 
cercana de la escuela al fuerte es el símbolo que interpela a sujetos subalternos no solo al cumplimiento de la ley, sino a las autoridades militares y educativas.

En esta misma nota, el Comandante informa que:

Contrayéndose al mismo tiempo al mjor. Adelantamiento de los niños del establecimiento q.el gobierno le ha confiado ha formado una junta compuesta por el Juez de Paz y de los vecinos Juan José Rial y Don Manuel Alvarez pa.que vigilen y tomen a su cargo, la escuela de primaria en nombre de obligar a los padres de familia a mandar los hijos a ella... También a correg.las reclamaciones sobre el capellán sobre fondos pa.los gastos q.demanda el culto de la Iglesia, reunió en la habitación al vecindario a fin de acordar este punto, el sìndico nombrado p.r el gobierno D.Pedro Crespo y Dn.Ramòn Ocampo ${ }^{74}$.

En el primer párrafo de este documento, se desprende las acciones llevadas a cabo por la Junta de Escuelas creadas por el Reglamento de 1821 y la acción de obligar a los padres a enviar a sus hijos a la escuela. Esta actitud disciplinar responde a una ideología liberal que disponía en las nuevas naciones latinoamericanas la obligatoriedad social y política de educarse. Esta nueva estrategia político-educacional para estimular el estudio, deja entrever que se soslaya la acción de la iglesia ante las demandas económicas existentes por el párroco.

En julio de 1828, Lacarra comunica al ministro de Hacienda que el tesorero Patricio Rivero, quien había remplazado a Mitre en su cargo, deja una alta valoración de este funcionario, «dedicado hasta sus últimos momentos del desempeño de su empleo...» ${ }^{75}$. En su reemplazo es designado Don Valentín Cardoso, teniendo la aprobación del Ministro el 22 de agosto del mismo año.

En otro orden, y a pesar que Lacarra manifiesta su voluntad de mantener mejores relaciones con los indígenas a efectos de evitar las permanentes incursiones que sufría la población, no existen constancias de incorporación de aborígenes al sistema educativo:

Esta comandancia ha coincidido la necesidad de comenzar con los indios amigos la mejor armonía y ha sentido una negativa a la demora formando una gran cuadra p.a. Sarg.tos q.no tienen donde acomodar la $2^{\mathrm{a}}$ Comp.a. de $\mathrm{Cazad}^{76}$.

En el encuadre formativo de la población podemos tener en cuenta que hay registros de la presencia de dos niños afroamericanos como integrantes de la escuela lo que ratificaría los dichos de Biedma quien sostiene que algunos de los negros arrebatados en los barcos de Pedro I de Portugal serán destinados al Batallón de Cazadores, mientras que los restantes serían distribuidos en las familias más pudientes. Dentro de las obligaciones que le cabía a las mismas estaba la de vestir a los libertos, «alimentarlos y

${ }^{74}$ AGN., Sala X, C13, n. ${ }^{\circ} 2$, enero 27 de 1827.

${ }^{75}$ AGN, Sala X, C13, n. ${ }^{\circ} 2,26$ de julio de 1828.

${ }^{76}$ AGN, Sala X, C13, n. ${ }^{\circ}$ 2, enero 27 de 1827. 
hacerlos seguir las costumbres del país respecto de los jornaleros comunes». Según opinión de Biedma estaba entre los derechos de la gente de color el de ser educados ${ }^{77}$.

\subsection{Comandante Francisco Crespo}

E1 28 de febrero de 1831, Francisco Crespo como comandante político y militar de Patagones, se dirige al inspector de escuelas Saturnino Segurola solicitando la cobertura de la vacante producida por la renuncia del maestro Agustín Muñoz ${ }^{78}$. Este último había continuado la labor del primer maestro del estado provincial, Fermín Cernadas. Muñoz había asumido en marzo 1823 teniendo a su cargo la escuela del Fuerte, presentado su renuncia que redacta en la capital el 22 de marzo de 1831. En los considerandos de la misma dice:

...no hallándome en aptitud de volver a aquel destino que mi quebrantada salud afectada en el corazón de mas; siendo igualmente difícil el transporte de mi familia, tanto para los gastos de viaje evidentes al sueldo, como al trastorno y atraso que forzosamente ha de seguirse en la mudanza de una familia, ya establecida en esta; he pensado en renunciar y de hecho renuncio en manos de V.S. del empleo de maestro de Escuela, en aquel punto... ${ }^{79}$.

Más adelante, Muñoz solicita se lo designe en un pueblo menos distante, teniendo en cuenta los ocho años de servicios que había prestado al Estado «con aplicación y contrición». Según sus palabras el resultado es notorio atento a la cantidad de «discípulos instruidos», recibiendo el agradecimiento del vecindario. En un lateral del documento se observa que con la firma de Segurola, se enviaría a Muñoz a la Escuela de San Nicolás de los Arroyos.

Antes de dejar su cargo, Muñoz, deja al cuidado del juez de paz Don Nicolás García, libros y útiles como:

24. cuadernillos en gramática Española por Don Felipe Senillosa.

8. libritos en $8^{\circ}$ «ya viejos» Gramática de Catalá Codina.

12. cuadernos en gramática española...preguntas y respuestas sin autor.

12. cuadernillos de aritmética...de Felipe Senillosa.

12. cuadernillos de aritmética en $4^{\circ}$...de Señor Lancaster.

7. libritos nuevos Cuadernos de Ortografía sin autor.

22. libritos en $8^{\circ}$ Obligaciones del hombre de Juan Escóiquiz.

3. libros nuevos de Manual de agricultura don Tomas Grigera.

${ }^{77}$ Biedma, J. J. op. cit., pág. 41.

78 AHPBA, Ricardo Levene, Dirección General de Escuelas, Carpeta n. ${ }^{\circ}$ 815, febrero 28 de 1831, folio 48, n. ${ }^{\circ} 1667-10,{ }^{\circ}{ }^{14}$.

${ }^{79}$ AHPBA, Ricardo Levene, Dirección General de Escuelas, Carpeta n. ${ }^{\circ}$ 815, folio 48, n. ${ }^{\circ} 1668-10$, n. $^{\circ} 12$. 
3. Cuadernillos en $4^{\circ}$ Manual del Republicano.

16. libritos para leer Catecismo de la naturaleza...

22. catecismos nuevos de Astete.

20. id.añadidos por Melendez ${ }^{80}$.

11. cartillas de silabarios de 8 hojas en $8^{\circ}$.

6. Cuadernillos de 8 hojas Reglamento Sociedad de Educación.

75. Cartillas de lecciones de la Sagrada Escritura en planos de papel grueso bien tratados.

3. Cartillas chicas de caligrafía....

1, Cuaderno en $4^{\circ}$ manuscrito Instruc.n p.a.la enseñanza mutua.

18. lapiceras de lata con su abrazadera p.a. abrir y cerrar.

24. lápices de piedra.

2. idem de plomo.

35. cuadernillos de 5 pliegos de papel.

2. paquetes de tinta en polvo.

3. docenas de plumas de Alcatraz.

6. bancos con sus asientos.

1. Espaldar nuevo de angaripola alrededor de la sala ${ }^{81}$.

La relación de algunos de los objetos y bibliografía utilizada por la escuela de Patagones, tiene la finalidad de observar la interrelación entre las prácticas de escolarización y de lecturas como prácticas sociales y culturales de conocimiento. Esta amalgama de libros, cuadernillos y catecismos, nos permiten conocer la orientación curricular de las escuelas de campaña, los autores que reconocían los maestros y alumnos, las transformaciones de las escuelas en un territorio limitado, métodos, usos y funciones de objetos que nos permiten representar aulas, edificios, pupitres, material didáctico. Estos últimos formaban parte del trabajo cotidiano del maestro.

El comandante Crespo, informa a Segurola que ha reunido al vecindario para lograr una suscripción de 25 pesos que se pagaría como adicional al sueldo que paga el Estado. Esta paga adicional en metálico nos permite suponer que el vecindario actuaría en carácter de controlador del nuevo maestro, pretendiendo una elección acertada por parte de las autoridades educativas:

...elección acertada que lleve los deveres (sic) qu corespond.n al director de la juventud (sic) y a las esperanzas del vecindario; pues con esta primera condición es que queda comprometida la gratificación... ${ }^{82}$.

Siguiendo conceptualmente a Norbert Elías, la prolongada convivencia de las viejas familias —los Crespo, Álvarez, Mitre, Rial, García - facilitan su cohesión grupal, sin tener un tinte aristocrático o del

${ }^{80}$ Cfr. Sánchez Hita, B. «Cartillas políticas y catecismos constitucionales en el Cádiz de las Cortes: un género viejo para la creación de una nueva sociedad», http/revistadeliteratura.revistas.csic.es.

${ }^{81}$ AHPBA «Ricardo Levene», Dirección General de Escuelas, Carpeta n. ${ }^{\circ} 815$, Folio 48, n. ${ }^{\circ} 1666 .-10$, n. $^{\circ} 12$

${ }^{82}$ AHPBA «Ricardo Levene», Dirección General de Escuelas, Carpeta n. ${ }^{\circ} 815$, Folio 48, n. ${ }^{\circ} 1669-10$, n. $^{\circ} 15$ 
patriciado urbano, mantienen «conocimientos», como cifras, símbolos, palabras, que les brindará el poder potencial sobre los «otros», los grupos marginados ${ }^{83}$.

\subsection{Los comandantes de la transición (1829-1855)}

En 1829 ante la grave crisis económica sufrida por Patagones se había formado una Junta de Hacienda compuesta por el Juez de Paz, el Comandante, el tesorero y dos vecinos. Esta junta facilitaba una participación mayoritaria de los vecinos. Desde 1833, la comandancia de Carmen de Patagones como la de Bahía Blanca sufren, por las razones argumentadas anteriormente, cierto abandono en las iniciativas educativo-culturales. La escuela de Patagones sufre, como otras escuelas de vecinos y con las dificultades de los maestros ante la falta de pago de su sueldo y generando las lógicas renuncias en sus cargos.

En 1835 el coronel Juan José Hernández reemplazó a Sebastián Olivera. Hernández era tío del antiguo vecino don José Atkins.

En 1836 el preceptor Julián Bosquellas, reclama a Segurola el pago de haberes que le adeudan desde el mes de julio, solicitando el respectivo ajuste desde agosto por los meses no $\operatorname{cobrados}^{84}$. En una confusa carta de Bosquellas dice haber recibido orden...

...para pagar sus sueldos en lo sucesivo es preciso que haga un poder a su hermano o a la persona que ud.guste en la forma que el Sup.or gob.no ha ordenado a horas ultimamt.te, el poder fue mandado y queda en manos de mi hermano...

Más adelante, aclara que se presentó ante el tesorero de Patagones según le habían indicado por inspección quien:

...me dijo que la ultima orden del Sup.Gobno...le dicen lo sigte.al ser.Comandte. del Punto que tanto el sr.cura, juez de Paz y demás empleados que hagan un poder del mismo modo que lo ha hecho el Maestro de Escuelas... ${ }^{85}$.

Estos documentos evidencian las restricciones presupuestarias que comienzan a sufrir las escuelas para el pago de los haberes de sus maestros como el mantenimiento de las mismas. Asimismo permiten comprender nuevas prácticas históricas de escolarización durante esta etapa al surgir nuevas ins-

83 Elías, N. op. cit., págs. 116-117.

${ }^{84}$ AHPBA «Ricardo Levene», Dirección General de Escuelas, Carpeta n. ${ }^{\circ} 1168$, enero 16 y 19, año 1836, n. ${ }^{\circ} 27$, n. $2791-16$, n. $^{\circ} 35$.

${ }^{85}$ AHPBA «Ricardo Levene», Dirección General de Escuelas, Carpeta n. ${ }^{\circ} 1168$, enero 16 y 19, año 1836, n. ${ }^{\circ} 27$, n. $2791-16$, n. ${ }^{\circ} 35$. 
tituciones e instancias burocráticas como Juntas locales y poderes, que afectan la directa comunicación que tenían hasta ese momento los maestros con el Inspector de Escuelas.

El maestro Manuel de la Hoz junto al juez de paz Nicolás García comunica, a los pocos días, que como consecuencia de las razones expuestas por Bosquellas, presenta su renuncia ${ }^{86}$.

La llegada del maestro Mariano Zambonini en agosto de 1844 permitirá la subsistencia de la escuela de Patagones. Este maestro con solo 21 años «debió acreditar ante el gobierno, moralidad ejemplar, capacidad e instrucción suficiente, profesión de la fe católica y firme adhesión a la causa nacional de la Confederación a fin de obtener el permiso correspondiente» ${ }^{87}$.

El 30 de octubre de 1854, este maestro informa el estado de la escuela de Patagones al 31 de diciembre del año anterior. Según se deprende del mismo, asisten 30 alumnos, cuyo detalle adjuntamos en anexo VI, de los cuales 2 alumnos son negros y 3 son pardos. Además a través de este registro de alumnos podemos observar que la calificación por clase, grupo o etnia, queda evidenciado. Los alumnos blancos quedan identificados como «don», mientras los otros por su etnia: negros o pardos. En estos cinco alumnos existen 4 de ellos cuyo ingreso es reciente, pero además en cuanto a escritura y lectura las observaciones en general existen variables como de poco esmero, mala, regular deletreo y en cuanto a la asistencia el valor que aparece como mayor es interrumpida.

Francisco Fourmantin, francés nativo de Burdeos, se había distinguido en Patagones como corsario al mando del «Lavalleja» durante el conflicto con Brasil. Como Comandante reemplaza a José María García. Francisco Pita, con ironía, descalifica a este coronel de marina alias Bivois... «a quien por error o por broma de sus contemporáneos, en vez de "bivuá" que no es lo que significa en francés, se le llamaba «Bigúa» que era el mote con que se lo distinguía a uno de los bufones de Rozas» ${ }^{88}$. Este marino sufrió en 1845 la confiscación de sus bienes, por parte del gobierno de Rosas y concretado por el juez de paz Nicolás García.

Posteriormente, luchó en Uruguay al mando del general Paz, quien hará referencias favorables como marino en los puestos de peligro «en los comienzos de la Guerra Grande». Así lo certifica Paz como brigadier de la Republica Argentina y general de armas ${ }^{89}$. Regresó a Buenos Aires después de Caseros, siendo nombrado comandante militar del río Negro en 1852, hasta su reemplazo en 1854 por Julián Murga.

Silvia Ratto afirma que desde la fundación de Bahía Blanca, en 1828, y fundamentalmente a partir de 1840 se produce por el incremento de pulperías y casas comerciales tanto en Patagones como en aquella, produciéndose entonces una estrecha relación entre los dos poblados ${ }^{90}$. Este vínculo también se reflejará en los actores que participaban de los intercambios educativos como José Antonio Lasaga, Estanislao Araque y Zenón Ituarte como probaremos más adelante.

\footnotetext{
${ }^{86}$ AHPBA «Ricardo Levene», Dirección General de Escuelas, Carpeta n. ${ }^{\circ} 1153$, enero 28, año 1836, n. ${ }^{\circ} 2746-15$.

${ }^{87}$ Nozzi, E. Carmen de Patagones y su proceso educativo,Patagones, Publicación del Museo Histórico Regional Municipal de Patagones Francisco Viedma, 1971, págs. 22-23.

${ }^{88}$ Pita, F. op. cit., págs. 59-60.

${ }^{89}$ Cfr. Pereda, S. Garibaldi en el Uruguay, Tomo I, Montevideo: Imprenta «el Siglo Ilustrado», 1914, págs. 63-64.

${ }^{90}$ Ratto, S. op. cit., pág. 17.
} 
Reyna Almandos transcribe un documento del Comandante Rafael Boujeois de Bahía Blanca, solicitando al ministro secretario del departamento de Guerra y Marina coronel Manuel de Escalada, la casa que ocupa el mayor Francisco Iturra, que había pertenecido al vecino Don Pedro Gascone, y que ahora era propiedad del Estado. La misma sería adecuada y destinada como edificio para una futura Escuela, «que se necesita establecer para la educación de una juventud abandonada». Según este documento la misma ofrecía comodidad para «morada del preceptor» ${ }^{91}$. En la misma carta, el comandante solicitará también la designación de un sacerdote, atendiendo que la guarnición carece de él para auxiliar «a quienes mueren diariamente sin el consuelo que nos da nuestras creencias religiosas».

En 1854 el ministro Portela concede la casa solicitada por un grupo de 24 vecinos, quienes habían realizado una suscripción y contribución económica, a través del juez de paz para el sostenimiento de un edificio escolar. Entre los vecinos que participan de esta suscripción se encuentran los pulperos originarios de Patagones, Antonio Lasaga (\$10), Francisco Araque (\$5), Zenón Ituarte (\$20) y el comandante Boujeois (\$20). También se encontraban tres mujeres, Catalina Díaz (\$10), Luisa Varela (\$5) y Flora Varela $(\$ 10)^{92}$.

Fourmartin, como comandante de Patagones, reclama a las autoridades de la provincia un mejor sueldo para el maestro Zambonini y un médico para la población ${ }^{93}$. La mirada del comandante permitía poner bajo control todas las instancias de la vida y el cuerpo de una vecindad. Dentro del cuartel, como espacio disciplinario y con un contenido laicizado, colocaban bajo un mismo signo, la pedagogía, la educación y la medicina.

Según la estadística de 1855 de Bahía Blanca, sobre una población de 1345 habitantes urbanos y suburbanos, la población militar solo llegaba a 79 miembros entre oficiales y tropa, es decir solo un $6 \%$ de la población en general ${ }^{94}$. Es a partir de este momento, que considero coyuntural, se produce una paulatina desmilitarización en la población, que adquiere parámetros urbanos más precisos.

Podemos afirmar, que después de Caseros, no sobrevino la pacificación esperada en el territorio bonaerense. La insurrección del 11 de septiembre, la sublevación de Hilario Lagos y la posterior separación del estado de Buenos Aires, sin embargo estos hechos no impidieron la influencia ideológica de «civilización y barbarie» de Domingo Faustino Sarmiento y la doctrina cosmopolita para una política inmigratoria de Juan Bautista Alberdi que favorecía la incorporación y radicación de europeos hasta en la región sudoeste del territorio. Así queda plasmada en la circular a los cónsules del Ministerio de Gobierno y Relaciones de Exteriores de Buenos Aires:

\footnotetext{
${ }^{91}$ Documento del AGN, Documento del Estado de Buenos aires 5881, en: Reyna Almandoz, op. cit., pág. 37.

${ }^{92}$ Reyna Almandoz, op. cit., pág. 36.

${ }^{93}$ AGN, Sala X, C18, A4, n. ${ }^{\circ}$.

${ }^{94}$ AHMMBB, Cuadro Estadístico General del Partido de Bahía Blanca, 3er. Trimestre, año 1855.
} 
...si la emigración quisiera alejarse de los actuales centros de población y ocupar el territorio donde están los grandes puertos marítimos de Bahía Blanca y Patagones, la ley ha autorizado al Gobierno para concederle en estos lugares, terrenos en propiedad... ${ }^{95}$.

Del Proyecto de Organización para la Colonia Agrícola Militar en Bahía blanca, en su artículo 4, se desprende que la educación de la «juventud» iba a ser responsabilidad del capellán de la Legión.

La llegada de la Legión Agrícola conformada por italianos con mayor grado de instrucción y alfabetización, muestra un sistema particular de inmigración con códigos y prácticas militares, que gradualmente irán abandonando, para integrarse por su superioridad socio-cultural en los ámbitos de poder. Gracias a su mayor potencial de cohesión interna — por lengua y origen - comienzan a ocupar cargos en las instituciones locales, que excluyen poco a poco a los vecinos fundadores. El comandante militar Juan Susviela, el 2 de febrero de 1856 es el encargado de recibir a las primeras familias de esta Legión.

Integrantes de las familias Caronti, Sagari, Olivieri, Caviglia, Sisco, Pronsato, Vitalini, desde sus cargos y por instrucción recibida (médicos, maestros, boticarios) fueron promotores de la cultura escrita a través de la introducción de la primera imprenta de Bahía Blanca, traída por el coronel Olivieri, que permitió imprimir el periódico La Legione Agricola, además de vales que circulaban en el comercio local como billetes de banco. El periódico apareció por primera vez, tres días antes que se embarcaran para Bahía Blanca, en la ciudad de Buenos Aires el 21 de enero de 1856, siendo su director Juan Bautista Cúneo. Este diario traducía la voz de los legionarios en esta región a través de diversas crónicas.

En enero de 1855, el preceptor Patricio Castro, dirigía la primera escuela de varones, comenzando a funcionar con 30 alumnos. Al igual que en Patagones la escuela contaba con un modesto mobiliario y con la discontinuidad laboral de los maestros.

El 25 de julio de 1855, Castro eleva su renuncia, con comunicación al rector de la universidad, donde denuncia «haber acallado...las exigencias del Señor Juez de Paz sustituto y de uno de los miembros de la Comisión (Municipal)» ${ }^{96}$. En esta misma renuncia, deja asentado la presión recibida por el pueblo que lo induce a pedir su relevo por el sueldo que recibía del gobierno, decidiendo presentar su dimisión por el incumplimiento continuo del pago de sus haberes. Sumado a los «...perjuicios que ha tenido que sufrir en no poder ir embarcado». La vacante de Castro, será cubierta por el preceptor Diego Miranda que era trasladado como pasajero, por orden del Doctor Barros Pazos, junto a militares destinados a la fortaleza, en el buque de guerra «Rio Bamba».

La precariedad de los medios con que contaban estos maestros, están claramente descriptos en palabras de Miranda, cuando dice: «...haré cuánto esté en mi mano para que este establecimiento se abra el

\footnotetext{
${ }^{95}$ Archivo del General Mitre, op. cit., págs. 336-344.

${ }^{96}$ AHMMBB, julio 25 de 1855, n. ${ }^{\circ} 76$ y 77.
} 
$1^{\mathrm{o}}$ del entrante, aunque para ello sea necesario servirse de huesos para bancos y de las rodillas para mesas» ${ }^{97}$.

En 1856 Fourmartin pasó a desempeñarse como comandante naval y militar de Bahía Blanca hasta el asesinato de quien dirigía la Legión Agrícola Militar, el coronel italiano Silvino Olivieri ${ }^{98}$.Este marino fue reemplazado en Patagones por el coronel Benito Villar, entre 1855 a 1859. Villar entre diversas obras a favor del pueblo, edificó la primera iglesia en la zona sur, construyó una pirámide en la plaza, arregló la fortaleza y fundó la primera escuela de niños de Viedma.

Dentro de las iniciativas culturales de Villar se encuentra la solicitud al Ministro del Departamento de Guerra en noviembre de 1855 de la creación de una banda de música, atento el «...estado de desunión en que se hallan los habitantes de este Pueblo y por consiguiente de abatimiento pues sienten un mal estar ageno (sic) de su índole inocente fraternal en que vivían...».

La banda de música generaría una forma de unión. Vecinos desalentados participarían también un grupo de soldados de esta guarnición, teniendo en cuenta que tienen un sargento que es un «excelente profesor de música». El ministro se hace eco de este petitorio instrumentos musicales como platillos, bombos, clarinetes, trombón, corneta y trompas ${ }^{99}$ Villar, como comandante, encuentra en la música una forma de producción cultural que permitiera evitar las rupturas vecinales, que manifiesta en la «desunión» y en un factor que mantiene su permanencia emocional, que es el «abatimiento», producto de un sentimiento de abandono que está permanente en la población de este punto urbano.

Como sostiene y ratifica Barba, el estado de incertidumbre provocado por el avance indígena en la frontera entre 1855 y 1857 afectó además las distintas formas de producción ganadera. Según este autor, en 1854 la población en Bahía Blanca era de solo 941 habitantes mientras que en Patagones de 1672, observándose que en ambas poblaciones desde 1834 el crecimiento fue sumamente lento.

La correspondencia de Benito Crespo a Bartolomé Mitre en 1855, en un tono coloquial lleva a decirles

... ¡ay, mi amigo i la principal cuita que agobia a esta mísera población no está en mi mano salvarla. Nada se puede hacer ni intentar en su beneficio, si previamente no se aseguran sus fronteras contra los indios bárbaros, dueños y árbitros hasta hoy de nuestros campos y de nuestros bienes ${ }^{100}$.

Apelando a su condición de «hijo de este suelo», en esta misma carta, Crespo solicita más adelante la colaboración y colonización del territorio entendiendo que ello llevará al progreso de Patagones:

\footnotetext{
${ }^{97}$ Reyna Almandos, op. cit., documento del 27 de febrero de 1856, págs. 43-44.

${ }^{98}$ Cfr. Crespi Valls, A. Primer Centenario de la Legión Agrícola Militar. 1856-1956, Bahía Blanca, Municipalidad de Bahía Blanca, Museo Histórico, 1950, págs. 7-8.

${ }^{99}$ AGN, Sala X, C19, A3, n. 3 .

${ }^{100}$ Archivo del General Mitre, Cartas confidenciales de varios sobre diversos asuntos, Buenos Aires, Biblioteca de la Nación, Tomo XI, págs. 96-97.
} 
En esta triste que Patagones no puede por sí solo salvar situación, me he acordado por dicha de que en Ministerio de Guerra, existe un amigo, un hijo de este mismo suelo que más de una vez me ha ofrecido cooperación.

Como punto de partida en el análisis de la correspondencia entre Crespo y Mitre, nos permite considerar como el conocimiento, los vínculos con el poder y las capacidades en lectoescritura de un vecino, permite regular y definir problemas, considerando posibles soluciones como aceptables y efectivas.

Benito Crespo, considerado uno de «los héroes del Cerro de la Caballada», en 1855 gestiona en la capital la designación de una preceptora para la escuela de señoritas de Patagones. Paradójicamente, el vecino plantea por un lado el problema constante que genera las invasiones indígenas, que afecta el comercio y la fuerza de trabajo y la escuela aparece como un segundo espacio de elección de una estrategia de desarrollo comunitario, extendiendo el beneficio a las mujeres.

\subsection{Comandante Julián Murga}

En Patagones, el comandante Villar será relevado por Julián Murga en 1862. Patagones constituía el nodo principal entre los contactos entre mestizos, indígenas y criollos. Murga, debe desafiar por sus vínculos con tehuelches y puelches los quiebres entre la sociedad indígena del siglo XIX y un incipiente pre capitalismo provocados por la creciente militarización que permite cierta expansión económica en la región, facilitada por una mayor seguridad para establecimientos rurales, saladeriles y pequeños comerciantes.

En enero de 1856, el vecino Marcelino Crespo le informa a Mitre desde Patagones, de los sucesos «de este desgraciado pueblo» sobre las desavenidas relaciones que generó Murga entre la vecindad. Según el juicio de Crespo, el comandante busca homogenizar su poder sobre un futuro gobierno civil buscando imponer en la lista municipal del comandante coronel Benito Villar (1856) a vecinos como Aguirre o «Barasas», que es el médico de la guarnición. Descalifica la figura de Baraza y la de Nicolás García, quien «fue juez de paz todo el tiempo de Rosas» y «se puso el cintillo». También desconfía del nombramiento del juez de paz Eusebio Ocampos. Confiesa que su intervención permitió suspender las elecciones cuando se trataba de formar la municipalidad de Patagones ${ }^{101}$.

Según Emma Nozzi después de 1852 y habiendo caído Rosas, Carmen de Patagones comienza a organizarse en el plano de la enseñanza elemental. Siguiendo a esta autora, el 9 de abril de 1854, la comisión municipal invitó al pueblo al fomento de la escuela primaria que se hallaba establecida, en razón del informe de su preceptor de la escasez de alumnos que contaba la misma. El acta fue firmada, por el juez de paz y presidente municipal Marcelino Crespo, el mensajero de la victoria del Combate del

${ }^{101}$ Archivo del General Mitre, Presidencia de la República, Cartas Confidenciales de varios sobre diversos asuntos, Tomo XV, Buenos Aires, 1912, págs. 329-331. 
7 de marzo, el cura Miguel Marchiano 102, el médico Francisco Baraja y Manuel Crespo, Ignacio León y Eusebio Ocampos.

En junio de 1863, Murga, comunica a Bartolomé Mitre, los diferentes intentos por pacificar la región de los avances indígenas. Informa que con motivo de la llegada de Chicoleo se realiza una gran reunión de caciques en la que se trató de «hacer la paz con el gobierno». Admite haber recibido del cacique Inacayul «una carta poder de todos los caciques que concurrieron a ella, en la que lo autorizan para tratar» ${ }^{103}$. Podemos definir, que la estrategia de este comandante estaba puesta en la pacificación de la región e impedir mayor cantidad de avances indígenas.

Durante la transición liberal (1852-1864) existen factores como la consolidación de una opinión pública ilustrada que inscriben nuevos actores en el proyecto educativo: negros, pardos, indígenas y mujeres y que permiten regular las relaciones del Estado con los docentes. Como lo demuestra la nota del comandante militar José Llano quien solicita el 17 de mayo de 1862 al presidente de la municipalidad de Bahía Blanca y juez de paz Mauricio Díaz extender indios amigos de este punto aprovechen «los beneficios de la educación primaria que el gobierno tan generosamente pone a su disposición...» ${ }^{104}$.

En esta instancia podemos diferenciar distintas formas de acción dentro del proceso educativo de la región del sudoeste bonaerense por parte de los comandantes político militares:

En un primer momento, que se extiende desde 1821 hasta 1831, la fortaleza en sus cargos y de sus iniciativas culturales, enmarcadas en el modelo liberal rivadaviano estaba en relación directa con los vínculos con subalternos y con una minoría vecinal ilustrada. El éxito o fracaso de la gestión quedaba — en algunos casos - supeditada a el apoyo o la conflictividad con la vecindad.

Un segundo momento, que abarca prácticamente todo el gobierno de Rosas y hasta 1854, el vecino - sobre todo quienes pertenecen a las familias de los fundadores - es protagonista porque alcanzan mayor cohesión y superioridad en el poder: ocupan cargos como comandantes o jueces de paz. La mayor permanencia en sus cargos no estuvo en relación con idéntica continuidad de maestros y preceptores donde subyace en sus renuncias el problema de los fondos destinados a la educación en esta etapa.

Un tercer momento, que permite visualizar la tardía percepción de la caída del rosismo después de Caseros. Nuevos modelos y prácticas educativas se visualizan junto al ingreso de una inmigración italiana militarizada pero que puede ser enmarcada en el concepto de intelectuales, que le confiere Pierre Bordieu. En tanto su autoridad científica y su conocimiento, se convierte en una especie de «capital social» que les confiere poder sobre organismos constitutivos. Valores como «reputación», «prestigio», «autoridad» son concurrentes y a su vez los distingue de sus antecesores y «desclasados» ${ }^{105}$. Ellos

102 Nota: el presbítero Marchiano, nativo de Génova, fue el último que dirigió la Curia Eclesiástica de la región durante el gobierno de Rosas en Patagones, siendo recibido por el comandante de Patagones en enero de 1852.

103 Archivo del General Mitre, Presidencia de la República, años 1862-1868, Buenos Aires, Biblioteca de la Nación, 1913, Patagones, junio 12 de 1863, págs. 45-47.

${ }^{104}$ AHMMBB, 17 de mayo de 1862.

${ }^{105}$ Cfr. Bordieu, P. Intelectuales, política y poder, Buenos Aires: Eudeba, 1999, pág. 81. 
ocuparán en especial en Bahía Blanca, espacios de poder como maestros o en la municipalidad y en el juzgado de paz. 


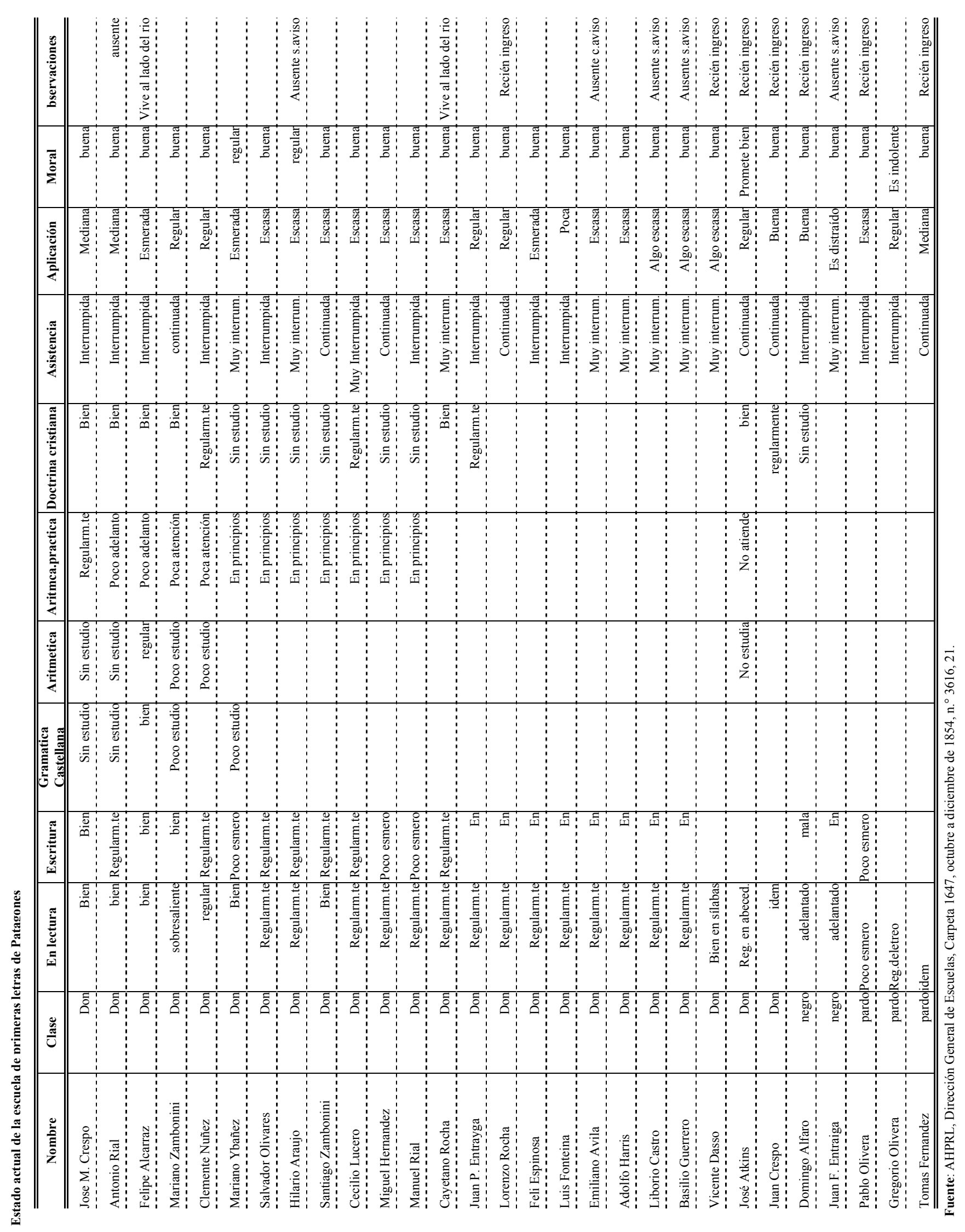




\section{La mujer como «intermediaria cultural» de dos mundos: masculinidad o femineidad}

\subsection{Dimensiones culturales del saber femenino}

La incursión en el análisis de «lo femenino» como ámbito de oposición a lo masculino, implica tomar nuevas perspectivas en la observación y estudio de la documentación archivística.

Teniendo en cuenta que estas fuentes documentales han sido escritas, en su mayoría, por hombres, implica adscribir nuevos significados a lo femenino.

La educación es la categoría laboral donde la mujer logró insertarse en la sociedad productiva y a su vez le permite vincularse y trascender a través de sus escritos. Estos son un medio de vinculación con organizaciones más complejas. El acceso al conocimiento y, como resultado de ello, la difusión del mismo procede a situarlas en el ámbito de profesiones jerárquicamente estructuradas. Hemos procedido a evaluar cómo en el contexto correspondiente a los años 1821 a 1862, se generan prácticas educativas que responden a una delimitación territorial fronteriza con marcadas singularidades de dos culturas que se oponen: la indígena y la «cristiana» o «civilizada», en la frontera del Sudoeste bonaerense.

El estudio de las prácticas educativas —en forma específica en el ideario femenino- permite reproducir usos y significaciones que tienden fundamentalmente a caracterizar las configuraciones culturales de tres oposiciones femeninas: la indígena, la cautiva y la blanca o cristiana. Y la vinculación que existen entre las prácticas educativas vinculadas con el mundo familiar o cotidiano con una formación intuitiva, a aquellas que le imprimen las instituciones culturales de un «Estado» en formación.

Pretendemos en este punto más que reproducir una historia educativa cronológica, estudiar el efecto que sobre la mujer ejerció la vida en la frontera y la dicotomía entre el hombre como individuo activo en la vida práctica y como organizador, todo ello facilitado por una mejor alfabetización y por ser el primer agente alfabetizador, como hemos visto en el caso específico de Patagones y posteriormente, en Bahía Blanca.

La historia de la mujer educadora supone la ampliación de los límites de cualquier historia de la educación, con sus criterios profesionales, su discurso y las desiguales relaciones con el ámbito masculino $^{106}$. Adoptamos el término de «educadora» por cuanto esta mujer no alcanzará hasta la década del ochenta del siglo XIX, niveles de formación específica en las escuelas o de preceptores y su preparación de vínculos familiares o conyugales con mayor índice de alfabetización.

La mujer es, una primera etapa, agente pasivo y signo exclusivo de maternidad, período que se extiende desde fines del siglo XVIII hasta que por decreto del 2 de enero de 1823 se crea la Sociedad de Beneficencia, dentro de un proceso de una nueva construcción del Estado Nacional. Esta sociedad

${ }^{106}$ Knecher, L. y Panaia, M. (comps.) La mitad del país. La mujer en la sociedad argentina, Buenos Aires: CEAL, 1994, pág. 40. 
integrada por mujeres patricias de Buenos Aires dejó de existir en 1838. El 16 de marzo de 1852 se restablece el accionar de esta institución, dentro del marco de la reforma de un gobierno liberal ${ }^{107}$.

\subsection{Grupos de pertenencia de las mujeres de frontera}

Actualmente distintos autores han realizado diversos estudios sobre la mujer y la familia, siendo este un nuevo género de abordaje histórico que se inicia fundamentalmente en la Argentina, a partir de la década del ochenta ${ }^{108}$. Parafraseando a Cecilia Morgade, todo análisis que aspire a comprender e interpretar los procesos sociales con profundidad, no puede dejar de considerar una de las dimensiones constitutivas tanto de la sociedad como de la subjetividad: las relaciones de género ${ }^{109}$.

Lo expresado no significa desconocer el aporte de diferentes investigaciones y estudios históricos que se han realizado con anterioridad y que abordaron la temática femenina y/o familiar desde aquellas mujeres que fueron «destacadas» por su participación en acontecimientos políticos, militares, o en su labor como educadoras y en un menor grado como periodistas. En casi todas estas obras la trascendencia histórica de estas mujeres está dada por acciones o pensamientos que no se inscriben en lo cotidiano, sino que las vincula con un hecho o acción que es singular, que es propio de una alternativa histórica donde ocupan un papel como «partícipe necesario». En algunos casos pertenecen a la élite porteña o de las ciudades del interior, que les permite acceder sin dificultad a los esquemas del poder.

No es el caso de la mujer de la frontera, por ello, nos proponemos rescatar del universo femenino a quienes les cabría la calificación que le asigna Michelle Vovelle a los «intermediarios culturales» ${ }^{110}$. Es decir, buscar las claves de «mujeres anónimas», marginales que «aparentemente parapetadas en el secreto de una aventura individual...parecían testimoniar por grupos más amplios, en ese intervalo que separa la cultura de la élite de la de las clases populares» con la correspondiente ubicación en un espacio geográfico, aislado por vía terrestre y delimitado por el marco de dos culturas: la indígena y la europea ${ }^{111}$.

Como hemos analizado anteriormente, el desarrollo histórico de la educación en la frontera del sudoeste bonaerense presenta rasgos distintivos y otros comunes entre las poblaciones de Patagones y

107 González de Bernaldo, P. Beneficencia y gobierno en la ciudad de Buenos Aires (1821-1861). www.ravignanidigital.com.ar/_bol_ravig/n24/n24a02.pdf.

${ }^{108}$ Algunos autores como Cicerchia, R. Historia de la vida privada argentina, Buenos Aires: Troquel, 1998, pág. 274, consideran que la historiografía de la familia y la mujer en la Argentina, tiene un notable impulso a partir de 1978, con un número especial del Journal of Family History. Otros como Dora Barrancos, en: Historia y género, Buenos Aires: CEAL,1993, entroncan esta nueva vertiente, con una reconceptualización de la teoría marxista de la historia, treinta años atrás.

${ }^{109}$ Cfr. Morgade, G. (comp.) Mujeres en la educación.Género y docencia en la Argentina. 1870-1930, UBA Instituto de Investigaciones de Ciencias de la Educación, Buenos Aires: Miño y Dávila Editores, 1997.

${ }^{110}$ Vovelle, M. op. cit., pag. 161.

${ }^{111}$ Ídem, pág. 165. 
Bahía Blanca. Entre los distintos, la Ciudad del Carmen, cuenta un pasado histórico que se enlaza con el siglo XVIII y ya contaba con una escuela pública de varones en 1821. El maestro constituyó para esta sociedad una categoría social que no está pensada en términos de fortuna sino producida por distancias culturales ${ }^{112}$.

Las capacidades culturales de los hombres, como por ejemplo, el saber leer y escribir, o sus bienes culturales, como el libro, se convierten en elementos suficientes para situarlos en espacios sociales que los separarían, momentáneamente, de lo popular, por ser la educación, un beneficio de la minoría.

Uno de los componentes comunes entre ambas poblaciones fue la incidencia que tuvieron los cuerpos militares (entiéndase fundamentalmente por sus comandantes de frontera) en lo que respecta a las solicitudes de maestros de escuela o de instalación de nuevos establecimientos.

La Sociedad Lancasteriana de Buenos Aires como la de Patagones eran asociaciones que pertenecían exclusivamente al universo masculino.

Estas sociedades masculinas son creaciones de hombres que determinaban, por tanto, una educación «para varones», preocupación primaria de los entes gubernamentales. El modelo político-educativo de Rivadavia resultó desafiante para el imaginario político de la época con la creación de la Sociedad de Beneficencia, poniendo en tela de juicio la vieja convención de que las preocupaciones de la familia y el hogar eran incompatibles con la vida pública.

Carlos Mayo, al estudiar la mujer en el mundo rural en la etapa colonial, destacó en un párrafo que el «analfabetismo estaba muy extendido entre los estancieros, especialmente en sus mujeres». Sobre un total de 30 hacendadas, solo 4 sabían leer y escribir ${ }^{113}$. Si bien estos datos corresponden a una etapa y un espacio geográfico distinto al analizado, cabe tener en cuenta la preexistencia de patrones de conducta en las zonas rurales.

En Patagones, se dio un caso particular, según la documentación analizada con la llegada en 1781 de Francisca Sánchez, hija del español Pedro Sánchez y de Bernarda Pérez ${ }^{114}$. Un año después contrae matrimonio con un oriundo de Galicia, José Rial, comenzando a dar clases en su domicilio únicamente para varones. Su hija Marcelina Rial de Álvarez será inspectora de la escuela de niñas en $1856^{115}$.

En una carta dirigida a María de las Carreras, presidenta de la sociedad de beneficencia, Marcelina dice «...haber tenido el honor de haber sido designada para regir la Escuela de Niñas de la ciudad», establecimiento que contaba con 15 niñas como alumnas y que aumentaron a 24 en solo 3 días ${ }^{116}$.

${ }^{112}$ Chartier, R. El mundo Como representación, Barcelona: Gedesia, 1995.

${ }^{113}$ Mayo, C. «La mujer en el mundo rural», en: Estancia y sociedad en la Pampa, 1740-1820, Buenos Aires: [s/e], 1995, págs. 165-178.

${ }^{114}$ AH Municipal de Carmen de Patagones.

115 Debenedetti, E. C. «Carmen de Patagones y la enseñanza primaria: 1821-1881», en: Segundo Congreso de Historia de los Pueblos de la Provincia de Buenos Aires. La Plata, AHPBA «Ricardo Levene», 1974. Esta autora apellida a esta maestra como Real. En los documentos analizados la docente firma como Real, no obstante en la información recaba en el Archivo Histórico de Carmen de Patagones, en las publicaciones de Biedma, Emma Nozzi es apellidada como «Rial».

${ }^{116}$ AHPBARL, DGE, Legajo 4185, n. ${ }^{\circ}$ 24, Carpeta 1871, año 1856. 
La primera preceptora designada nunca llegó porque enterada del ataque indígena a la población decidió renunciar. «Lamenta la infrascrita — dice Marcelina Real- que cuando se preparaba la preceptora nombrada para venir a la escuela encargada, haya llegado a desanimarla esa noticia funesta de la invasión de indios con que se ha completado el atraso material de esta población» ${ }^{117}$ Por ello La Sociedad de Beneficencia designó entonces a Benjamina L. De Sebestes.

El esposo de Marcelina era porteño, dominaba varios idiomas y poseía una amplia cultura. En este espacio geográfico, alcanzan otra dimensión social aquellos sectores con un índice más alto de alfabetización. Es este factor uno de los aspectos que lo separa al «intelectual del pueblo». En pequeños centros urbanos los «intelectuales» aparecen ligados al clero, a una casta militar y a los «grandes» propietarios o comerciantes ${ }^{118}$.

Este aspecto se agudizó en la etapa donde aún no se había alcanzado la separación definitiva de los laicos con la Iglesia. Todos estos elementos se conjugarían si tenemos en cuenta que Álvarez era ganadero, empresario y miliciano. En abril de 1852, el gobernador provisorio Vicente López lo designó juez de paz y comisario de policía de Patagones. El nuevo juez de paz, que había participado en las guerras de la Independencia, estaba establecido en Patagones desde 1823. Fue, como ya analizamos oportunamente, miembro activo de la Sociedad Protectora de la Educación.

Estaba vinculado con integrantes de algunas familias y vecinos notables de Patagones como los Mitre, Vicente Dasso (porteño), Juan Dasso (genovés), Ignacio León (nativo), Celedonio García (nativo), José Atkins. Algunos de los citados integraron organismo de supervisión escolar, como por ejemplo, una comisión para supervisar arreglos de las escuelas.

En este contexto social, Marcelina Real, demuestra por su correspondencia con las autoridades de la Sociedad de Beneficencia, que desde su espacio laboral no solo existe preocupación por las prácticas cotidianas del proceso de enseñanza aprendizaje, sino que se vincula con autoridades locales dando fuerza a sus petitorios ${ }^{119}$

En una gran mayoría, la mujer educadora de frontera, hasta la década del setenta del siglo XIX, no trasciende al ámbito de lo público, porque si bien el lenguaje que enseña deja de ser patrimonio exclusivo del hombre, no logra aún insertarse en las instituciones.

\subsection{La mujer educada y las cautivas en la Fortaleza Protectora Argentina}

En Bahía Blanca este proceso es más tardío en relación a Patagones si tomamos como referencia la acción y correspondencia de Marcelina Rial (1856) y sus vínculos con autoridades locales favorecida por el accionar como funcionario de su esposo. A partir de 1833, con la Campaña al Desierto de Juan Manuel de Rosas, el enclave insular de un fuerte como la Fortaleza Protectora Argentina, aislado en los

\footnotetext{
${ }^{117}$ AHPBARL, DGE., Legajo 4184, n. ${ }^{\circ}$ 24, 26 de agosto de 1856.

${ }^{118}$ Gramsci, A. Los intelectuales y la organización de la cultura, op. cit. pàg. 30.

${ }^{119}$ AHPBARL, DGE, Legajo 4183, n. ${ }^{\circ}$ 24, 19 de mayo de 1856.
} 
confines territoriales, genera tipologías femeninas variadas, cuyos cambios se traducen en la relación con el proceso de alfabetización de la región.

Durante la etapa rosista algunos jueces de paz aparecen como hombres ignorantes o escasos de educación, fenómeno que comienza a modificarse en la década del cincuenta cuando se puede observar, a través de la construcción lingüística de sumarios y expedientes, formas de expresión discursiva más desarrolladas.

Atendiendo que son escasos los testimonios escritos que han aportado las mujeres en el período y espacio geográfico que nos ocupa, debemos recurrir necesariamente a los aportes que realizan quienes son, fundamentalmente, «actores activos» dentro del mundo masculino: los comandantes de frontera, jefes de regimiento, jueces de paz. Por otra parte, la mujer — en muchos casos con insuficiente o ningún grado de alfabetización-, en un mundo carente de escuelas, bibliotecas o acceso a otros niveles de estudio, muestran para el historiador, un vacío como la pérdida de expresiones originales, debiendo suplir el mismo con la visión de viajeros, de sumarios judiciales que las tienen por «partes», víctimas de secuestros o testigos.

Los testimonios femeninos parecen transitar casi en exclusividad en la temática educativa, a partir de este momento, cuando la educación se plantea como el espacio de participación posible para las primeras «damas inquietas» que se muestran interesadas en sus pequeñas comunidades por el hecho educativo. Ubicadas estas «intermediarias culturales» entre dos mundos, le permiten adquirir una visión de la realidad en la cual la incomunicación terrestre actúa como disociador de cualquier intento de sistematizar la educación:

«La distancia inmensa que separa ese punto de la ciudad, hace casi impracticable la comunicación directa que, anhela con vehemencia conservar con ese importante Departamento» 120 escribe la presidente de la Sociedad de Beneficencia desde Buenos Aires al Juez de Paz de Bahía Blanca en 1855. Aunque la decisión ha sido tomada: «Sin embargo, esto aun no es lo bastante para debilitar una idea que la sociedad tiene hace algún tiempo de ver establecida en ese punto una Escuela de Educación de Niñas». Afirmación que evidencia un contraste profundo de pensamiento y acción con una época o tiempo diferente, demostrando su identificación con esta última, atendiendo que ella está aún en estado embrionario.

Confia que quien tiene la responsabilidad de desarrollarlo es el juez de paz: «El superior gobierno, señor, tiene especial empeño en que las costumbres sean modificadas después de un largo tiempo que han estado los habitantes de la campaña, oprimidos bajo el enorme peso de la fatalidad...» ${ }^{121}$

El signo femenino de la fatalidad queda vinculado al designio divino que ejerció sobre este sexo. Cabe preguntarnos si existía en las mujeres de esa élite intelectual que dirigían los destinos de la educación una idea de designo en que su participación activa en lo educativo resultaba en efecto la contrapartida con el de su exclusión de actividades que participen en el proceso productivo como en otras formas de producción económica. Esas damas hacedoras de discursos educacionales como el que hemos

${ }^{120}$ AHMBBB, Doc. s/f.: abril, 1 de 1855.

${ }^{121}$ Idem. 
reproducido, son capaces de elaborar cierta propuesta política educacional, válido únicamente para un grupos sociales que participarán de los beneficios de la educación.

Existe en el pensamiento del período que nos ocupa una caracterización imaginaria de la mujer que la vincula con su familia, y con las virtudes a cumplir como «el complemento» necesario del sexo masculino. Como lo sostiene Simone de Beauvoir es el «Otro» quien le asigna existencia, y por ende, sustento de sus actitudes como la de espera y tierna docilidad ${ }^{122}$. El trabajo femenino que no hará peligrar esa concepción y en el cual quedará identificada con su rol familiar será, por un lado aquel que reproduzca ese ámbito: el cuidado de niños, las tareas del hogar y la educación de niños. La escuela por lo tanto - representaba la posibilidad de no desarrollar actividades o trabajos que la identificaran erróneamente con el ámbito masculino.

Tal como lo aseveramos anteriormente, la historia de la mujer anónima de la frontera la que ha carecido de estudios de mayor profundidad, entendiendo a estos como aquellos que requieren un tratamiento de lo que Davidson, J. y Mark, H. Lytle llaman «the people of bottom rail» ${ }^{123}$. Las acciones individuales de estos anónimos testigos aparecen como escasas de producir efectos en el curso de la historia. Muchas de estas mujeres escribieron cartas, guardaron diarios, relataron sus experiencias, que permiten con sus descripciones recrear la vida en la frontera y la experiencia en un espacio en permanente conflicto y de constante movilidad ${ }^{124}$.

Son pocos los testimonios documentales que ofrecen descripciones de lo femenino, entre 1833-1853, en el territorio que nos ocupa. La ocupación de estas tierras emprendida por Juan Manuel de Rosas en 1833 legitimó no solo la extensión de una frontera, sino que fue significativa tanto desde un punto de vista militar, político y fundamentalmente cultural.

En una «conquista» donde los protagonistas principales son un comandante y sus soldados, el sujeto masculino es centro de ese universo y por ende de la herencia discursiva. Siguiendo la fundamentación teórica de Lucía Guerra, en todo proceso de colonización política y económica, es corriente que se construya al Otro colonizado como una colectividad anónima ${ }^{125}$.

Los signos colectivos, «indios», «negros»o «mujeres», pierden su individualidad diferenciadora, donde el sujeto colonizador, unifica características físicas, idiomáticas, culturales, sin preocuparse por darles un símbolo distintivo, aunque en casi todos ellos subyace la reafirmación de la inferioridad femenina, merecedora de descripciones que la igualan al de las exóticas especies de fauna y flora de un desconocido espacio geográfico.

La mujer no es merecedora de mayores análisis, en los documentos que ilustran esta «epopeya», es decir, El Diario de la Expedición al Desierto, de Juan Manuel de Rosas y los Partes detallados de la

${ }^{122}$ Beauvoir, S. de. El segundo sexo, Tomo II, Buenos Aires: Siglo XXI, 1987, pág. 105.

${ }^{123}$ West Davidson, J. y Hamilton Litle, M. After de fact__The art of historical detection, 2nd edition, New York: Alfred A. Knopf, 1986.pag. 180.

${ }^{124}$ Uno de los trabajos que abordan sobre la vida de la mujer en la pampa, son el de Villafañe Casal, M. T. La mujer en la pampa (siglos XVIII y XIX), La Plata: edición de autor, 1958. Villar, D.; Di Liscia, M. H. y Caviglia, M. J. (comps.) Historia y género. Seis estudios sobre la condición femenina, UNS y UNLP: Biblos, 1999.

${ }^{125}$ Guerra, L. La mujer fragmentada. Historias de un signo, Bogotá: Casa de las Américas, 1994, pág. 23. 
expedición al Desierto, recopilación del coronel Garretón ${ }^{126}$, sino que aparece breve y genéricamente descripta, destacando solo a la mujer indígena y a la cautiva. Los partes contenían escasos elementos de análisis, aunque se observa que luego de todo enfrentamiento con indígenas, se procede al inmediato rescate de mujeres y niños «cristianos cautivos».

El 14 de octubre de 1833, en el relato del triunfo de las tropas rosistas sobre el cacique Cayupán en el río Valchetas, familias indígenas son rescatadas y remitidas a los fuertes. En otro parte del 31 de diciembre del mismo año, Rosas revela que las cautivas reclamadas por sus familias son enviadas a sus respectivos hogares de Salto, Navarro y Monte Grande. La mujer, por lo tanto, se convierte en motivo de arraigo y asentamiento familiar, y con una doble finalidad, como compañera de su «hombre» en la frontera, además, evitaría las permanentes fugas de gauchos incorporados en el ejército fronterizo ${ }^{127}$.

En este punto no podemos obviar el análisis exhaustivo y las estadísticas que sobre la temática realiza Susan Socolow sobre los cautivos españoles. Socolow pone énfasis que la experiencia de haber sido capturado era lacerante psicológicamente, tratando de sostener la cultura española y el idioma. Para la autora, las mujeres españolas que pasaron la mayor parte de su vida nunca perdieron la conciencia de ser españolas, testimoniando que las mujeres podían hablar castellano porque otras cautivas se lo ensenaron $^{128}$.

El propio fundador de la Fortaleza Protectora Argentina había anotado y descripto en su «diario» de marcha en 1828, la entrega por parte de indios «amigos» de mujeres y niños cautivos. El agrimensor Narciso Parchappe, escribió en su diario: «El coronel las hizo vestir y las distribuyó en las casas ya construidas. A mí me da una niña de ocho años, a quien a él se le ocurre nombrar Armida» ${ }^{129}$. Estas cautivas se convirtieron en las primeras mujeres «blancas y cristianas» asentadas en la fortaleza. Casi cincuenta años antes, habían sido precedidas por otras mujeres blancas, en el fuerte de Carmen de

${ }^{126}$ Ambas obras editas, conservan detalladamente el «Diario de la Expedición», no siempre escrita por Rosas, aunque los borradores contaron con su revisión. El primero de ellos integra una serie de ediciones sobre el Indio y el Desierto de Editorial Plus Ultra, Buenos Aires, 1965. Los «Partes detallados de la expedición al desierto de Juan Manuel de Rosas en 1833», es una recopilación de escritos, comunicaciones y discursos del coronel Juan Antonio Garretón, publicados en la prensa de Buenos Aires desde 1819 hasta 1833, incluyendo el diario de marchas. Buenos Aires: Eudeba, 1975.

${ }^{127}$ Uno de los partícipes activos de esta expedición, el general Ángel Pacheco, escribe al Dr. Guido, «Nuestra población ba (sic) a aumentarse con familias de estos indios, las mujeres (sic) nos serán (sic) muy útiles pr.qe.son (sic) laboriosas y acostumbradas a un asiduo trabajo, ya hay bastantes en mi campo y viven muy contentas, hasta ahora ninguna ha intentado fugar», en: Corvalán Mendilabarzu, D. Revista Militar, n. ${ }^{\circ}$ 530, Buenos Aires, pág. 452. Rosas, en coincidencia, y escribiendo al general Pacheco desde el río Colorado, manifiesta en esta carta, su interés por recuperar las cautivas que tiene los ranqueles y devolverlas nuevamente con sus familiares.(Microfilm n. ${ }^{\circ} 154$ del Archivo General de la Nación, Departamento de Humanidades, Gabinete 26, Universidad Nacional del Sur, Documentos del general Angel Pacheco, noviembre 19 de 1833 ).

${ }^{128}$ Socolow, S. «Los cautivos españoles en las sociedades indígenas: el contacto cultural a través de la frontera argentina», Anuario IEHS, Tandil, Universidad del Centro de Buenos Aires, 1987, págs. 99-135.

${ }^{129}$ Sobre este episodio y la relación de Estomba con las cautivas, lo he descripto en un artículo de mi autoría: «El coronel Don Ramón Bernabé Estomba y su contexto histórico», Boletín Histórico, n. ${ }^{\circ}$ 7, Bahía Blanca, Comisión de Reafirmación Histórica,1980, págs. 6-10. 
Patagones, donde la presencia de las mismas, data de fines del siglo XVIII. Francisco de Viedma narrará como el indígena toma conciencia que el asentamiento de mujeres, implicaba la futura pérdida de las tierras. Es decir, la existencia de ellas quedaba vinculada intuitivamente por el indígena, con la pérdida de sus posesiones. Lo colectivo queda igualado, el indígena como parte de una organización social fundamentada en las transacciones masculinas de intercambio de la mujer, propias de un sistema patriarcal, ve invadida su exclusiva territorialidad. No obstante, perdura el concepto que la incorporación de familias en un territorio fronterizo era una forma de legitimar su posesión ${ }^{130}$.

Tanto los viajeros como el mismo Narciso Parchappe, aseguran la presencia de las primeras mujeres y niños blancos quienes podían ser vistos entre los indígenas ${ }^{131}$. La mujer y el caballo son dos de los elementos más preciados por el indígena. Por ello, el rescate de estas cautivas se realizaba muchas veces a través del intercambio de caballos con los indígenas, aunque ello no impedía que algunas regresaran nuevamente hacia las huestes del «bárbaro»:

Cuando la expedición del coronel Rauch contra las tribus del sur, numerosas mujeres blancas que rescató huyeron para volver con los indios. Durante las marchas nocturnas, se arrojaban de la grupa de los caballos, donde las llevaban los soldados, y se salvaban a favor de las tinieblas ${ }^{132}$.

Esta situación se debía — probablemente - a la necesidad de regresar con quienes se identificaba o mantenía vínculos de pertenecía a través de sus hijos. Indudablemente, existía en ella una crisis de identidad, tal como lo manifiesta Woodbine Parish, al decir: «Muchas de estas pobres mujeres hacía muchos años que estaban en sus manos, otras no podían dar razón ni indicio de a quién pertenecían...» ${ }^{133}$.

Pero es probablemente el relato del padre Lino D. Carbajal sobre una cautiva, el que realiza un mayor aporte al ideario femenino de una mujer en la frontera ${ }^{134} \mathrm{Si}$ bien es un sacerdote quien transcribe, lo que permite inducir la imposibilidad de la mujer de escribir, es tal vez, quien llega a describir con mayor

${ }^{130}$ Documenta este aspecto el microfilm del Archivo General de la Nación, caja 18, n. ${ }^{\circ}$ 91, año 1829, Familias para la nueva frontera, abril 29 de 1829.

${ }^{131}$ Parish, W. Buenos Aires y las Provincias del Río de la Plata, Trad. Justo Maeso. Buenos Aires: Hachette, 1958, pág. 279. Este viajero inglés reconociendo la influencia que el nombre de Rosas ejerció sobre los indígenas, afirma que las tropas de este general, ha salvado más de 1500 mujeres y niños, cuyos maridos, hijos y hermanos, había sido bárbaramente asesinados.

132 D’Orbigny, A. op. cit., págs. 353-361.Sobre la idea de maternidad no existe una distinción genérica que caracterice a la mujer indígena de manera diferente .Basta leer el relato sobre el encuentro con la hermana del cacique Chanel, cautiva de otro cacique, quien había sobrevivido escapando y cuidando de sus posesiones más caras: los hijos y los caballos .

${ }^{133}$ Idem, pág. 279.

${ }^{134}$ Ginóbili de Tumminello, M. E. La cautiva o Rayhuemy. Relato histórico inédito del Padre Lino D.Carbajal, Instituto Superior Juan XXIII, Bahía Blanca, 1995. Esta obra me fue gentilmente ofrecida junto con un valioso aporte documental, por la autora. 
claridad esta dualidad de quien comparte una vida con un otro de diferente origen étnico y valores, que se contraponen con un esperando rescate de su «propia cultura».

Cuando Rosas vino al Colorado, mandó a un jefe a parlamentar con ellos...Este jefe era el Sr. Mayor Eugenio Del Busto... Él era nuestra esperanza y entre los cautivos no hablábamos de otra cosa que de este noble y valeroso ex-cautivo ${ }^{135}$.

El relato se detiene a describir los castigos corporales a que eran sometidas estas cautivas, ante la sospecha indígena de un posible rescate. La mujer relegada a la actividad natural — fogón doméstico, cuidado de niños - quedaba totalmente impedida de manifestar su oposición a las disposiciones masculinas. La belleza no siempre significaba un privilegio, cuando ésta pretendía manifestar una opinión distinta: «¡Pobre amiga mía! Purantey. Era mujer buena y bonita, pero algo franca y tal vez por esto el bárbaro apenas respondió le dio tal golpe de macana que ella rodó por tierra bañada en su sangre...» ${ }^{136}$.

La mujer y los niños carecen de derecho a la palabra, ubicada en un sistema patriarcal, el cual reviste un signo subordinante.

El rescate se volvía en una epopeya, donde la mujer se convierte en protagonista de su propia liberación, abandonando transitoriamente su inmovilidad protagónica. La vida de la cautiva igualada con la de la mujer indígena, recupera en la liberación la posibilidad de compartir con «mujeres civilizadas» la educación que es aún patrimonio exclusivo del sujeto masculino: «Luego nos ayudaron a terminar nuestro tocado y ornamento - dice la cautiva - esmerándose en hacernos aparecer como verdaderas cristianas civilizadas, como hijas y madres de hombres educados» ${ }^{137}$.

La higiene femenina era parte de la distinción con otra cultura. Parchappe había descripto como la falta de aseo de la mujer indígena resultaba repugnante al viajero: «Esas mujeres cuyos rasgos no siempre son repelentes, son asquerosas por la suciedad de sus ropas...» ${ }^{138}$. La contrapartida de una sociedad culturalmente desarrollada era para la cautiva, la higiene y el arreglo femenino: «...las señoras nos invitaron a despojarnos de los andrajos que vestíamos... mostraban tanta caridad como interés en esta parte trayéndonos hasta el agua y jabón al salón» ${ }^{139}$.

La sociedad educada, de «señoritas y señoras» del pueblo es higiénica, y mantiene hábitos de un determinado ordenamiento social: el suelo como lecho y mesa, es reemplazado por sillas, platos y utensillos. Las descripciones de viajeros, muestran a las mujeres indígenas acostadas sobre cueros o con las piernas dobladas al estilo oriental.

En todas las descripciones sobre las indígenas, el trabajo de ellas casi se iguala a la condición de sus propios niños, es la encargada de salar y cortar la carne obtenida por el hombre en la caza; y descalza,

\footnotetext{
${ }^{135}$ Ginóbili de Tumminello, M. E. op. cit., pág. 18.

${ }^{136}$ Idem, pág. 20.

${ }^{137}$ Idem, pág. 48.

${ }^{138}$ D’Orbigny, A. op. cit., pág. 401.

${ }^{139}$ Ginóbili de Tummninello, M. E. op. cit., pág. 48.
} 
acompaña al hombre paso detrás de él arrastrando los animales y todos sus pertrechos, distinguiendo su inferioridad. Sin embargo, sin abandonar su dimensión biológica y maternal, la mujer a través del bautismo y el matrimonio religioso abandona su condición de «salvaje».

El hombre no solo es el ser fuerte y activo, frente a la «debilidad» femenina, sino que es el «primer instructor» de la simbología religiosa. «Lucero era un buen cristiano - dice la ex-cautiva- y no solo a nuestros hijos inculcaba la fe y la piedad, sino que a mí misma me instruyó en todo lo que sabía al respecto» ${ }^{140}$.La religión es el primer símbolo de formación y el matrimonio religioso entre hombres pertenecientes al ejército de Blandengues o guarniciones fronterizas, es una práctica social que le permite a la mujer un paulatino acercamiento a las instituciones formadoras.

Otros rasgos que distinguen la «cultura de los blancos» es el idioma. El castellano y su adquisición o pérdida determina una categorización social. La mujer que perdía su manejo idiomático era porque había incorporado a su lengua la «araucana». En 1847, en una carta que la excautiva Manuela Valenzuela envía a Rosas, desde Patagones, relata al gobernador en forma breve parte de su historia. Aunque reconoce que su hija María que ha sido cautiva por los indígenas no la ha podido recuperar como sí lo ha hecho con sus hijos varones, porque «no la quisieron entregar, según costumbre de los indios, en caso de cautivas niñas...Reteniéndolas las pueden criar a su gusto, las hacen perder el idioma cristiano y luego casan con los jefes de la tribu» ${ }^{141}$. Esa mujer indígena no tiene otros elementos que la distingan.

Parchappe destaca la actuación de una intérprete femenina, llamada Lunareja que dominaba tanto el castellano como el araucano, e impone una figura de excepción, en cuanto a su relación con el lenguaje. La imagen de esa mujer contrarresta con la de la esposa del «Comandante» del fuerte de Carmen de Patagones, «con esos modales distinguidos y especial amabilidad que caracterizan a las señoras de buenas familias de Buenos Aires ${ }^{142}$. Para la perspectiva del viajero que mistifica lo maternal, a partir de la propia construcción conceptual que le permite su universo masculino, la mujer «puelche», «araucana» o «patagónica» se reduce a ser un cuerpo que nutre y protege al niño y a su familia, y es elemento de transacción entre ambas culturas.

En referencia a lo que hemos denominado mujer educadora debemos señalar que a pesar que no obran en los archivos consultados correspondencia de las instituciones fronterizas del Sudoeste bonaerense que fueran escritas o firmadas por mujeres, Reyna Almandoz reproduce un documento fechado el 10 de julio de 1833, firmado por Victorio García de Zúñiga en el cual acuerda que el Comandante político y militar de la Fortaleza Protectora, designe a una preceptora de primeras letras que dependería de la Sociedad de Beneficencia $^{143}$. La creación de esta escuela y la designación de una preceptora no se concretaron. Esta mujer, Polonia Ituarte encabeza una «relación de los familiares de los oficiales» del Regimiento de

${ }^{140}$ Idem, pág. 70.

${ }^{141}$ Este documento inédito me ha sido facilitado por la investigadora Ginóbili. Si bien la carta es manuscrita, la misma no fue escrita por la excautiva, dado que en la firma figura «a cargo de doña Manuela Valenzuela, Mariano Francisco Gómez», que es quien suscribe la nota.

${ }^{142}$ D’Orbigny, A. op. cit., pág. 372 .

${ }^{143}$ Reyna Almandoz, A. op. cit., págs. 79-80. Según este autor la mujer sería Polonia Ituarte de González. 
Dragones, firmada por su esposo, el capitán Fabián González, no registrándose más datos que su condición de mujer blanca ${ }^{144}$.

Este aspecto corrobora la hipótesis planteada sobre la vinculación que los miembros de ejército y milicias tiene en la frontera como agente educador, en tanto existía una relación vincular entre oficialidad-alfabetización, que generó una red familiar muy peculiar en el contexto social de Bahía Blanca.

La estratificación social de una primera etapa abarcaría hasta 1854 y mantiene un estrecho contacto entre lo militar y lo educativo.

Después de Caseros, la Sociedad de Beneficencia comienza a adquirir nueva relevancia en lo concerniente a la educación femenina. Ello nos permite recuperar el testimonio escrito de la mujer. A partir del decreto del gobernador de Buenos Aires, del 26 de octubre de 1852 que creaba un Departamento de Primeras Letras, dependiente del rector de la Universidad de Buenos Aires, los jueces de paz de las ciudades de la campaña adquieren atribuciones que se proyectan más allá de lo exclusivamente legal: atender a los pedidos y propuestas para la instalación de escuelas públicas. Entre sus atribuciones se establecía la elevación no solo de las propuestas de creación sino también de nombramientos de preceptores y métodos de enseñanza. Esta reformulación educativa también tendrá su eco en la Sociedad de Beneficencia que en abril de 1852 dado el cúmulo de actividades solicita aumentar el número de socias ${ }^{145}$.

Creada la primera escuela de varones de Bahía Blanca, será un hombre quien en su condición de juez de paz se comunique con la presidente de Sociedad de Beneficencia, María de las Carreras, a quien previene de «los vicios» en que puede caer una mujer si no es educada.

La creación se demorará hasta 1857 a pesar de la petición del juez de paz Jerónimo Calvento quien solicita la creación de una escuela de niñas con lo cual «cesaría el motivo que las induce a las mujeres a permanecer en la calle». La escuela sería dirigida por Rita Rodríguez de Sagari, comenzando a funcionar en noviembre de 1858. Esta educadora era madre de un oficial de la Legión Agrícola Militar, Pedro Sagari.

La llegada de esta educadora como preceptora de la escuela y de su hija Máxima era anunciada por la presidente de la Sociedad de Beneficencia, Ignacia Beláustegui, al Juez de Paz de Bahía Blanca ${ }^{146}$. En carta que dirige a esta entidad, la preceptora demuestra tener conciencia del espacio profesional que está ocupando así como su capacidad para tomar decisiones que dejan en claro una mayor conciencia de sus potencialidades y de la especificidad de su trabajo como «empleada pública»: «También suplico se informe si es justo que como empleada publica y madre de un oficial de la Legión Militar esté obligada a pagar flete y pasaje como se le exige». «Llegan noticias que el ejército se va a retirar; si tal sucede no

${ }^{144}$ AHMMBB, Padrón de 1836, Inv. 14-36.

${ }^{145}$ AHPRL, 27-4-1852, Carpeta 1298, Folio 82, Dirección General de Escuelas.

${ }^{146}$ AHMMBB, 13 de febrero de 1858. 
permaneceré mas tiempo que la demora en esperar un barco, pues esto queda a ser presa de los salvajes» $^{147}$.

En mayo de 1860 ambas educadoras abandonan Bahía Blanca. Previa a su partida, una comisión integrada por Nicolasa Presiado de Díaz y las maragatas señora de Real y señora de Dasso, habían procedido a entregar premios medallas y libros a las siguientes niñas:

* Medallas: Catalina Díaz, Agustina Pérez, Petrona Castillo, Robustiana Lasaga.

* Libros: Isidora San Román, Demetria López, Pastora Díaz, Pastora Flores, Paula Lasaga, Rosa Laspiur, Inés Araque, Clementina Araque, Gregoria Palao, Rafaela Palao, Mauricia Olivera, Isidora Pueblas ${ }^{148}$.

A petición del juez de paz Julio Casal, se designa Inspectora de Escuela a Adela Casati de Caronti, dama vinculada a la Legión Agrícola. Esta mujer había abandonado Italia en 1855 junto a su esposo capitán Felipe Caronti quien con Olivieri eran un grupo de republicanos liberales y demócratas mazzinianos. A diferencia de Sagari, el esposo de Casati demostró conocer y apreciar la acción educativa sarmientina, teniendo clara influencia en distintos acontecimientos que hicieron a la evolución educativa de Bahía Blanca. Caronti hará, en sus Memorias, un expreso reconocimiento a las virtudes y cualidades de su esposa ${ }^{149}$.

El 20 de enero de 1860 llega a Bahía Blanca María del Carmen Meroz de Ambrosetti, que inicia las clases el 1 de febrero con 16 alumnas, aumentando a 22 en junio de 1861. Esta educadora se desempeña hasta 1862, cuando el juez de paz Mauricio Díaz recomienda al gobierno municipal a cargo de don Sixto Laspiur, la solicitud de una nueva preceptora. Fermina Míguez de Ferrer, quien requerirá de nuevo mobiliario para escuela recibiendo pupitres confeccionados en Buenos Aires ${ }^{150}$.

El 14 de enero de 1866 el cura párroco, municipales y vecinos elevan a la Sociedad de Beneficencia el petitorio de designación como preceptora de la escuela pública de niñas a la inspectora Ciriaca Palau de Laspiur y como monitora a la señorita Gregoria Palau.

Ciriaca Palau constituye al igual que Marcelina Real de Álvarez arquetipos de la mujer educadora de frontera. Palau nacida en Bahía Blanca el 18 de junio de 1838, bautizada como Ciriaca Pabla por el presbítero Jose Nicolás Aquarone, era hija de uno de los vecinos fundadores, Eustaquio Palau y de su esposa Rufina Brandan ${ }^{151}$. Su padre poseía una esmerada educación y se lo apodaba «bachiller» aunque su oficio era de albañil según el acta bautismal ${ }^{152}$. Era hermano del capitán de regimiento de Dragones

${ }^{147}$ Libro del Centenario, op. cit., pág. 655.

${ }^{148}$ AHPBARL, D. Escuelas. Leg. 4086, folio 48, 1 de enero de 1860. Del listado de alumnas se puede deducir por sus apellidos que existen familias maragatas asentadas ya en Bahía Blanca. Igualmente, de estas niñas se puede observar además que eran algunas de ellas hijas de jueces de paz o miembros jerarquizados de la Legión Agrícola.

${ }^{149}$ Memorias de Felipe Caronti, Traducción del italiano de la señora Bianca Sartori de Mozzi en: Boletín Histórico n. ${ }^{\circ}$ 13, Bahía Blanca, Comisión de Reafirmación Histórica, 1984.

${ }^{150}$ AHMMBB, 17 de junio de 1865.

${ }^{151}$ Libro del Centenario, op. cit., pág. 656.

${ }^{152}$ Libro de Bautismos de la Iglesia Parroquial, AHMMBB. 
Francisco Antonio Palau de la Fortaleza Protectora. En 1858 fue designado juez de paz y presidente de la Corporación Municipal. Ciriaca estaba casada con el médico cirujano de la población don Sixto Laspiur, que había arribado a Bahía Blanca en 1830. De esta unión habían nacido cuatro hijos: Valentín Sixto, Ciriaca de los Ángeles, Sixto Ciriaco y Amelia Máxima Estefanía ${ }^{153}$. La señora de Laspiur continuó al frente de la escuela hasta 1879.

Sondeando su correspondencia, esta educadora manifiesta claramente su preocupación por las niñas marginadas de la educación y en su discurso escrito reproduce — por su énfasis - la mentalidad de las mujeres alfabetizadas con respecto a su visión del mundo y del espacio que las rodeaba.

\begin{abstract}
Al Señor Presidente de la Municipalidad
En vista de sus repetidas notas de la sociedad de Beneficencia y de la circular que últimamente ha dirigido a la Inspectora de esta Escuela...referente todas al fondo producido por las asignaciones de las niñas pagas, a pesar de haber dado cuenta en repetidas veces, que en este pueblo de familias demasiado pobres, no están en las mismas circunstancias de otros y que para no poner trabas a las enseñanza y que todas las niñas participen de ella, a ninguna he exigido el pago, privando es verdad al Establecimiento de un recurso que sería muy útil, pero renunciado al mismo tiempo á la parte que por reglamento le pertenece del dicho fondo, por obtener una ventaja mayor, que es la asistencia de todas las niñas en estado de educar...no puedo permitir que a la distancia y donde no me conocen puedan creer que existan fondos de que no doy cuenta. Firmado: Ciriaca Palau de Laspiur ${ }^{154}$.
\end{abstract}

Según se desprende de la documentación analizada, puede comprobarse el prestigio que manifiestan los miembros de la comisión evaluadora hacia esta educadora. Esta «intelectual» vinculada a la pequeña burguesía de este centro urbano representaba un modelo social para quienes no estaban alfabetizados, en su aspiración de salir de su condición o mejorarla. Idéntica actitud se observará en los elogios de la Comisión Municipal hacia esta mujer.

Solo nos resta haora (sic) tributar ante la Corporación Municiapal los justos elogios que se merece la preceptora, la que ha seguido con sus desvelos y contracción a formar unas alumnas que le hacen mucho honor y que sigue manteniendo este establecimiento a la altura en que debe estar en este siglo ${ }^{155}$.

Estos párrafos evidencian una paulatina ruptura a las premisas de definición y habilitación laboral de un pasado histórico entre el hombre y la mujer y que la conducirá a una creciente participación económica de la sociedad.

${ }^{153}$ Nota: Ciriaca de los Angeles, nacida el 2 de agosto de 1859, aparece nueve años después, en los registros de la distribución de premios recibiendo una medalla. AHMMBB, 19 de septiembre de 1868, Amelia Máxima también aparece en el registro de escuela de niñas en el mismo documento, donde dice tener 7 años.

${ }^{154}$ AHMMBB, 19 de octubre de 1868.

${ }^{155}$ AHMMBB, 19 de setiembre de 1868. 
Las escuelas de niñas instruían a ellas en lectura, escritura, y cuentos. En cuanto a las actividades prácticas se las educaba en costura, bordados en blanco, cribar y dimanar, trabajos en seda, en oro, en terciopelo, mostacilla y felpilla, marcas de punto entero y medio punto, tejidos, cadenas de pelo y botones de seda ${ }^{156}$. El fundamento de la diferencia de la educación de ambos sexos ya no corresponde a partir de ahora del plano dogmático de la fe o del matrimonio, sino que establece para la mujer todo aquello que afirme su condición de tal, alejándola de todo conocimiento con cercano a las ciencias exactas o de la búsqueda de verdades abstractas o especulativas. La mujer repite en la escuela las conductas que luego desarrollará en la casa.

Las invasiones permanentes de los indígenas desaniman el asentamiento de estas primeras maestras y se convierte en razón de abandono de sus cargos. Esta inestabilidad es motivo de reclamo hacia las autoridades educacionales por parte de estas mujeres y los temidos malones que acechaban ambas poblaciones ${ }^{157}$.

\section{Premios y lecturas de las escuelas de mujeres de la frontera}

Los premios concedidos a las alumnas en medallas o libros no resultaban suficientes para paliar la falta de útiles, que reclaman y que van desde percheros, bancos, lápices de papel, lápices de pizarra, catecismos de doctrina cristiana. Entre los libros resulta llamativo que mientras para los varones se enviaban obras sarmientinas como Argirópolis, Viajes de Sarmiento por Europa, América y África, Educación Popular, Recuerdos de Provincia, Facundo, y textos como Química Orgánica de Bustillos, El ¿Por qué? o la Física popularizada ${ }^{158}$.

La maestra de Patagones, Marcelina Real de Álvarez reclamaba a la presidente de la Sociedad de Beneficencia, María de las Carreras que provean de «cartillas y silabarios» a las niñas. Mientras que en Bahía Blanca, Fermina Míguez de Ferrer reclama en 1864 por «cuadernos para $2^{\circ}$ y $3^{\circ}$ de la Anagnosia» ${ }^{159}$.

Las niñas eran preparadas en la escuela, por la maestra o el párroco, si es que la población lo tuviere, en Doctrina Cristiana para la Comunión ${ }^{160}$. Tal como lo disponía el Departamento de Escuelas el 15 de julio de 1862, los exámenes eran públicos y en la iglesia de cada parroquia. La educación religiosa

${ }^{156}$ AHPRL, Leg. 1276, folio 81, 1 abril de 1852.

${ }^{157}$ AHRLLP, Leg.4184, n. ${ }^{\circ}$ 24, Carpeta 1871, año 1856.

${ }^{158}$ AHRLLP, Leg.1398, Leg. 18, Folio 88, año 1852.

${ }^{159}$ La Nueva Provincia, Libro del Centenario de Bahía Blanca, op.cit. pág. 656. Se desconoce el significado de estos cuadernos, pero seguramente, están haciendo referencia a escritos de anagogía o escritos de interpretación religiosa.

${ }^{160}$ AHMMBB, Doc. n. ${ }^{\circ}$ 2556, Maria de las Carreras, como presidente de la Sociedad de Beneficencia le escribe a la «preceptora» de la escuela de Bahía Blanca, recordando que «dé órdenes un poco anticipadas,sobre su escuela,p.q.la maestra prepare las niñas p.a.la comunión comunión anual,como está mandado que sea el 8 de Diciembre». 
ocupa un lugar privilegiado en la formación de una mujer que debe ser ante todo «buena cristiana», virtud que acompaña al de «buena madre».

La lectura — siguiendo el concepto de Roger Chartier ${ }^{161}$ — es una práctica y una historia de las formas de leer se convierte en un signo que identifica las comunidades de lectores, las capacidades de lectura y las formas de leer. Este aspecto será una diferenciación esencial entre alfabetos y analfabetos y a su vez, una clara delimitación en el segmento de alfabetos dados por lectores más o menos hábiles en razón de la complejidad de sus lecturas que visualizan un índice de diferentes procedimientos de interpretación por lo que podemos concluir que las lecturas que ampliaban el espacio de comprensión, no eran significativamente iguales para los hombres y para las mujeres, existiendo para ellas un acento definido hacia lo religioso, a lo dogmático más que a las ciencias exactas o su experimentación.

De todo lo analizado, podemos arribar a algunas conclusiones. La mujer aparece como un signo íntimamente unido a la apropiación territorial y a su paulatina jerarquización social. Las prácticas educativas desde 1833 hasta 1856 aparecen veladas por una memoria oficial que no las considera protagonistas y pierde sus testimonios individuales que llegan a través de los hombres con quienes participan en la difícil tarea de poblar. Si bien, frente al poder que ejerce lo masculino sobre lo femenino en esta etapa, la fuerza de ella está dada en ser razón de poblamiento y por ende de «civilización». Aunque no existan instrumentos estatales que la eduquen, su formación estará de la mano del hombre como «primer educador». El cautiverio en manos del indígena le impone una cultura que se recupera si el regreso es posible.-

La mujer sufre idéntica estratificación social que el hombre y son las mujeres de los oficiales quienes asisten a las poblaciones como educadoras en una primera instancia.

Aunque los datos aportados por los archivos no nos han permitido verificar la formación de estas primeras mujeres en la frontera del sudoeste bonaerense, el seguimiento de las redes familiares generadas en la primera etapa, permiten afirmar que de las familias de la oficialidad o quienes ocupaban los cargos más altos de ejército, surgen las primeras maestras de la segunda etapa cuando se institucionaliza la educación femenina. Algunas de ellas pertenecían a las familias fundadoras de estas poblaciones, aspecto que le otorgaba cierta «notabilidad», adquirida en algunos casos a través de casamientos con autoridades como jueces de paz o miembros de las comisiones municipales que legitimaban la apropiación del poder y por ende de la dirección de la educación.

El sistema educativo permite generar canales de participación femenina, aunque las prácticas educativas traten de perpetuar los códigos que identifican el ideario femenino: representar en la escuela las normas culturales de su entorno familiar, a través del bordado o costura y una literatura que responde más al catolicismo normativo de la iglesia, que al conocimiento científico y exacto. Este último, al igual que una mayor complejidad educativa, queda reservado para el mundo masculino.

${ }^{161}$ Chartier, R. Op. cit., pág. 108. 


\section{El educador masculino. Estrategias de adaptación a nuevos espacios. Reacción frente a la incertidumbre}

Habiendo analizado a la mujer como intermediaria cultural de dos mundos, el masculino y el femenino, buscamos primero, recuperar las existencias pasadas de hombres educadores y las redes familiares por ellos construidas en los dos espacios urbanos con la vecindad y su relación con la posesión de la tierra. Segundo, examinar sus prácticas educativas, los mecanismos unificadores o distintivos del resto del territorio bonaerense a través de sus estrategias discursivas que le permitían la adaptación o no, a un escenario cultural, de alta incertidumbre ante el latente peligro indígena, acorde a las coordenadas sociohistóricas. El análisis de su correspondencia con las autoridades educativas de la provincia de Buenos Aires, es ciertamente relevante por cuanto por cuanto permiten descubrir emociones, vivencias y conflictos vinculares con autoridades gubernamentales. $O$ aquellas cuestiones que afectaban a la cuestión de la estabilidad/inestabilidad laboral y salarial como sostén familiar, la pedagogía para las escuelas de varones y las experiencias educativas que diferenciaban a las de las mujeres.

\subsection{Redes familiares}

Siguiendo las formulaciones de Zacarías Moutoukias y Jean Paul Zúñiga en este punto me centraré en el parentesco con ciertos grupos de familias «notables» de los centros urbanos analizados tomando el modelo de la red de notables por tercera generación y ciertos mecanismos de movilidad geográfica y social, por parte en este caso de los educadores masculinos ${ }^{162}$.

Está claramente delimitada una suerte de organización entre las «familias fundadoras»o «familias notables» quienes mantienen relaciones de parentesco, vínculos o conexiones que los asocian en muchos casos en cuestiones comerciales, propietarios de chacras o pequeños establecimientos productivos, manteniendo estrechas alianzas con líderes políticos o miembros de la justicia local. En lo que respecta a esta investigación, el nivel de educación o el alcance al saber de los diferentes actores, es lo que determina la «notabilidad» de algunos de ellos en este espacio.

Al analizar a las mujeres educadoras hemos podido observar algunos ejemplos de alianzas matrimoniales interconectadas entre familias fundadoras, educadoras, comerciantes, que plantean la imbricación de funciones entre organización política, educativa, cultural y social de la región. Siguiendo el modelo metodológico de «tres generaciones» adaptado para estudios hispanoamericanos, esto supone

\footnotetext{
${ }^{162}$ Moutoukias, Z. «Familia patriarcal o redes sociales: balance de una imagen en la estratificación social»; Zuñiga J. P. «Clan, parentela, familia, individuo: métodos y niveles de análisis», Anuario IEHS, Tandil, 2000, págs. 5160 y $133-151$.
} 
una visión de redes familiares como grupos corporativos claramente delimitados, que en muchos tienen como punto de partida los cimientos fundacionales del espacio donde se desarrollan ${ }^{163}$.

Las conexiones se creaban por casamientos, hijos y parentesco colateral y dentro de esa red sus miembros mantenían una jerarquía de poder como dirigente de las principales instituciones en una primera generación con dominios en el lenguaje, en la lectura y epistemológico de las ciencias. Algunos de ellos, en primera instancia, enseñan a sus hijos — fundamentalmente a los varones - en sus domicilios y en una segunda generación ante la instalación de escuelas, estas familias disfrutaron de mayores oportunidades para enviar a los niños a recibir una educación formal.

El listado de alumnos que citamos anteriormente elaborado por el maestro Zambonini en 1854 confirmaría esta afirmación. La enumeración de los alumnos varones no era alfabético sino que en el casillero estaba categorizado por «clase», siendo los primeros quienes - a pesar de su corta edadmantenían el principio estructurador o clasificador por su color de piel llevando los primeros el tratamiento de don, mientras que los cinco últimos respondían a su color de piel: negros y pardos. Los alumnos que figuraban primeros en las listas pertenecían a una segunda y tercera generación de los castellanos fundadores de Patagones como las familias Sánchez, Crespo, Rial (o Real), Olivares, Harris, Guerrero, Dasso y Atkins. Estos lazos — si tomamos el principio durkheimiano de vincular los hechos a las cosas - nos permiten concebir la construcción en la escuela de un mundo social con lazos intrafamiliares de familias y niños. Las familias fundadoras adquieren un carácter de estatus de notabilidad una vez avanzado el siglo XIX, extendiendo su poder al gobierno local y fortalecidas por la activa participación en los hechos beligerantes de 1827.

Algunas de estas familias eran más dominantes que otras, situación facilitada por el acceso a la tierra pública y la construcción del poder político, militar ${ }^{164}$. El español Pedro Sánchez cuyo arribo a Patagones fue en diciembre de 1781 casado con Bernarda Pérez y cuya hija Francisca fue la primera maestra, también casada con el español José Real, son ejemplo de esta primera generación. Otros ejemplos podemos encontrar en las familias de Benito Crespo, casado con Matilde García; José Olivares, con Josefa García y Jaime Harris con Juana L. de Harris ${ }^{165}$. Sumados a ellos los hijos del maestro Zambonini: Mariano y Santiago. Otras familias cuyo protagonismo fue crucial en la educación de este espacio, son los descendientes de Pedro Sánchez y Bernabé Pita ${ }^{166}$.

${ }^{163}$ Cfr. Socolow, S. Mercaderes del Buenos Aires virreinal: familia y comercio, Buenos Aires: Ediciones de la Flor, 1991. Balmori, D.; Voss Stuart, F. y Wortman, M. Notable family networks in Latin America, Chicago: Chicago University, 1984; Acosta Rodríguez, A. «Las redes sociales, el poder y sus fundamentos», Anuario IEHS, n. ${ }^{\circ}$ 15, Tandil, 2000, págs. 153-170.

${ }^{164}$ Barcos, M. F. y Lanteri, S. «Tierras públicas y construcción del Estado de Buenos Aires en el siglo XIX. Las donaciones ejidales y condicionadas en una visión comparada», Boletín del Instituto de Historia Argentina y Americana Doctor Emilio Ravignani, n. ${ }^{o}$ 38, 3a serie, 1er semestre, 2013, Facultad de Filosofía y Letras, UBA, Buenos Aires, págs. 43-74.

${ }^{165}$ AHC de P. Juzgado de Paz, Planilla Estadística, Letra E, Caja 10, n. ${ }^{\circ} 202$.

166 Biedma, J. J. op .cit., págs. 92-99. Extraemos del listado de familias fundadoras algunos de aquellos que estuvieron vinculados con el proceso educativo de Patagones. 
$\mathrm{Al}$ analizar las planillas estadísticas de 1866, surge una segunda y tercera generación de algunas de las familias citadas, que permiten una nueva interpretación de la estructura social de Patagones, por cuanto se asentaba los vecinos que sabían «leer y escribir», existiendo una nueva correspondencia con el tipo de vivienda que estos vecinos poseían Un detalle que puede pasar por alto, pero que en un estudio cultural, nos permite ver la relación entre estilo de vida, tipo de viviendas (edificios de alto, de azotea, de dos plantas, palo a pique embarrado, techos de teja) y propiedades como «suertes de estancias», chacras, cantidad de animales, propietarios de almacenes ${ }^{167}$.

En el caso de Bahía Blanca, dentro de las familias fundadoras que surgen del padrón de 1836, dando mayor exactitud en lo que respecta al grupo familiar, que constituiría la «primera generación»: Juan Molina, oficial del primer escuadrón de Dragones casado con Juana Suárez; José María Araujo, casado con Vicenta Molina, Juan María Ituarte casado con Polonia Ituarte, Francisco Acosta y el maestro armero Juan Chacón con mujer y un hijo varón familiar. Como quinteros aparece Juan Francisco Díaz con mujer y cinco hijos y Rafael Muñoz casado con María Suarez y dos hijos varones. Dentro del grupo de militares podemos nombrar al sargento mayor José Quintana casado con Juana Rodríguez de Quintana, teniente segundo Andrés Sarmiento, José Hidalgo casado con Catalina Díaz ${ }^{168}$. Sus descendientes, la segunda generación, integran el listado de los primeros alumnos de la escuela de varones.

También en ellos, la posesión de la tierra es una forma de consolidar estos esquemas de alianzas familiares, basados en lazos de sangre y de matrimonio. Podemos dar algunos ejemplos de esta variable en la antigua Fortaleza Protectora Argentina: Cuadros militares como Francisco Iturra solicitan desde Bahía Blanca el 23 de junio de 1836 una suerte de estancia en su condición de Sargento Mayor Graduado $^{169}$. El primer juez de paz de Bahía Blanca, Francisco Xavier Casal, nombrado el 24 de febrero de 1832, solicita a la Comisión de Solares, recientemente formada e integrada por el comandante Martiniano Rodríguez, un amplio solar que se extendía frente al Fuerte (solar 1F) mensurado en 1835 y que pasa a las manos de su hijo Adolfo Casal ${ }^{170}$. Otros vecinos como el doctor Sixto Laspiur, Agustín Pedro Hugony, Zenón Ituarte y su esposa Polonia González, fueron favorecidos con solares y suertes de chacras cercanas al fuerte.

En la primera nómina de alumnos que concurrían a la escuela de varones, observamos que varios niños constituían tercera generación, dado que en la segunda, como sostiene Socolow, por lo general las alianzas eran complementarias con intereses mercantiles, con relación a posesión de tierras, pequeños comercios (pulperías) o pertenencia a los cuadros militares

${ }^{167}$ AHC.de P. Juzgado de Paz, Planillas Estadísticas, Letra E, Caja 10, n. ${ }^{\circ} 202$.

${ }^{168}$ AHMMBB, Padrón 1836.

${ }^{169}$ AHN, Gobierno Nacional, Sección gobierno de Bahía Blanca, Sala X, C16- A7, n. ${ }^{\circ} 7$

${ }^{170}$ Funes Derieul, C. «Los solares de la fundación», en: Libro del Sesquicentenario de la Fundación de Bahía Blanca, Bahía blanca: La Nueva Provincia, 1978, págs. 38-43. Los datos corresponden al Departamento de catastro de la Municipalidad de Bahía Blanca, Exp. 9, Leg. 9. 
En la primera generación, en la Fortaleza y a diferencia de Patagones, las actividades mercantiles estaban vinculadas a las pulperías, que nacieron para atender la demanda de la población y sus necesidades más elementales, siendo sus propietarios, los siguientes vecinos:

1. José María Araujo (1832)

2. Francisco Casal (1833)

3. José María Hidalgo (1834)

4. Pedro Gascone (1834)

5. José María Méndez (1836)

6. José María Araujo (1836)

7. León Cámara (1836)

8. Francisco Acosta (1836)

9. José Antonio Lasaga (1840)

10. Estanislao Araque (1841)

11. Mauricio Díaz (1841)

12. Zenón Ituarte $(1841)^{171}$

La pulpería — además - legitimaba la permanencia de extranjeros en la campaña y otorgaba prestigio social al propietario ${ }^{172}$. Los encuentros en las pulperías eran ámbitos no solo de expendio de bebidas alcohólicas, sino que en este contexto, puede interpretarse como espacios de socialización y discusión vecinal.

${ }^{171}$ Nota: Se hace mención solo a aquellos pulperos que tienen vínculos familiares con los primeros alumnos. Funes Derieul, C. «Pulperías de Bahía Blanca», Separata del Boletín Histórico, n. ${ }^{\circ}$ 4, Bahía Blanca, Comisión de Reafirmación Histórica, 1978, págs. 35-46. El autor adjunta copia de los documentos históricos del Archivo del Museo Histórico que avalan fechas de licencias otorgadas para su funcionamiento.

${ }^{172}$ Arrondo, C.; Figlioli, D. y Sanz, V. «Postas y pulperías en la campaña bonaerense. La visión de los viajeros. 1770-1820», Cuarto Congreso de Historia de los Pueblos de la Provincia de buenos Aires, Buenos Aires: Theoría, 1997, págs. 37-48. 
Nómina de alumnos varones que concurrían a la escuela de Bahía Blanca en mayo de 1858

Fuente: AHPBARL, Leg.42, n. ${ }^{\text {o } 3531 .}$

\begin{tabular}{|c|c|c|}
\hline Máximo Sotelo & Marciano Lasaga & Saturnino Marques \\
\hline Zenón Ituarte & Teófilo Cámara & José Godoy \\
\hline Raimundo Quintana & Raimundo Quintana & \\
\hline Gumersindo Espinosa & Luis Ancalo & \\
\hline Justiniano Hidalgo & Luis Ancalao & \\
\hline Teófilo Laspiur & Vicente Cavilla & \\
\hline Cayetano Casanova & León Quintana & \\
\hline Calixto Godoy & Luis Iturre & \\
\hline Pedro Araujo & Pablo Espinosa & \\
\hline Victorino Araujo. & León Ugarte & \\
\hline Antonio Valerga & Andrés Sarmiento & \\
\hline Pedro Hidalgo & Andrés Rolando & \\
\hline Guillermo Sánchez & Pablo espinosa & \\
\hline Rodolfo Casanova & Cirilo Hernández & \\
\hline
\end{tabular}

Del listado de niños que asisten a la escuela entre 1863 y 1864, destacamos a los niños Benito y Zalín Miranda, hijos del maestro: Alejo Casal, de la familia del primer juez de paz de Bahía Blanca, Juan Araque, de la familia Araque oriundas de Patagones ${ }^{173}$.

Estas variables de propiedad, contacto fluido con el poder central y saberes coincide con la tesis de Puiggrós en la relación entre educador y educando, los vínculos entre educador y educando, entre diferentes sujetos pedagógicos (niño blanco, pardo, chino, mulato negro o extranjero) y un educador (religioso, extranjero, blanco) y el «habitus». La autora — siguiendo a Bordieu— focaliza en la asociación que existe entre «habitus» y clase social, de manera que el «habitus de clase» resulta regulador del proceso de enseñanza-aprendizaje, al igual que condiciones de producción y distribución económica y los conflictos por la hegemonía entre sujetos sociales y políticos ${ }^{174}$.

\subsection{Prácticas pedagógicas y política educacional en las escuelas de varones}

Los niños recibían instrucción religiosa, lectura, escritura aritmética e instrucción general según consta de los informes de los educadores. La conducta del alumno era controlada no solo en la escuela sino también en la calle, en la iglesia y tenida en cuenta para la clasificación final, así como el aseo con que se presentaban. Al igual que con las niñas se aplicaba el sistema de premios luego del examen público, frente a una comisión formada por el cura de la parroquias, dos vecinos distinguidos. Los exámenes consistían en lectura, escritura, aritmética teórica y práctica, gramática y doctrina cristiana. La nómina de alumnos premiados era elevada al Juez de Paz.

\footnotetext{
${ }^{173}$ AHPBARL, Legajo 65, n. ${ }^{\circ} 5826$.

${ }^{174}$ Puiggrós, A. op. cit., págs. 30-31.
} 
«Se presentarán al examen todos los alumnos que pertenezcan a la Sección $1^{\mathrm{a}}$ o Superior de Doctrina y serán invitados a presenciarlo las familias en particular y el público en general» ${ }^{175}$.

Los documentos escritos entre educadores con sus autoridades del Departamento de Escuelas suelen mostrarnos a estos educadores cuya formación responde a las necesidades del entorno.

Los fundamentos de la política educativa del estado bonaerense a aplicar se encuentran claramente enumerados en los Anales de Educación Común en abril de 1860. Basa la política educativa que llevaría a cabo el gobierno en "poder prodigar recursos para la erección de escuelas», decretos que no "son la obra de un rapto de entusiasmo, ni del deseo de conquistar simpatías de parte del pueblo». El objetivo que se busca, según marca este artículo, es un porvenir mejor para el país. «El Gobierno está facultado para erigir escuelas por si, en los lugares donde el vecindario por demasiado pobre no pueda concurrir a satisfacer esta necesidad...», se sostenía desde las páginas de los Anales. Por otra parte, había una voluntad subsidiaria del estado cuando los vecinos no pudieren sostener las escuelas. «De poco ó de lentísimo efecto sería la ilustración que se difunde en las ciudades si la ignorancia crece como la cicuta en las campañas...» ${ }^{176}$.

La campaña era concebida como zonas de oscurantismo donde el analfabetismo podía generar fenómenos como en Francia e Italia donde en ámbitos campesinos se mantenían los dialectos que transformaba a esa aldea en una nación ante la variación de los idiomas. En estas líneas fortalece lo afirmado sobre la necesidad de unificar un idioma, el castellano, teniendo en cuenta no solo la diversidad lingüística de la población.

Desde el punto de vista disciplinar, el educador Zambonini muestra un especial interés en su correspondencia con Sarmiento por contar con un reglamento que especifique los deberes del preceptor para con el vecindario, «...y a su vez deje ver los de este para con el». Esta solicitud la realiza para evitar el cúmulo de abusos que dice sufrir ${ }^{177}$. Parafraseando a Puiggrós, existen conflictos en el interior del proceso educativo que puede ser interpretado como «enfrentamiento de estrategias» ${ }^{178}$. Este educador maragato plantea disputas lógicas con aquellos padres dejan a sus hijos en la escuela y jamás se acuerdan de pagar la mensualidad por su enseñanza como tampoco se interesan cómo son educados sus hijos. La gratuidad de la educación aún no está internalizada para Zambonini, quien se ha presentado en la municipalidad haciendo el respectivo reclamo por la falta de pago de sus alumnos. Allí fue informado que «la enseñanza por ser costeada por el Erario era gratis». En esta carta de reclamo, informa que de 56 alumnos solo pagaban 6 la mensualidad ${ }^{179}$

Este «enfrentamiento de estrategias» en las prácticas pedagógicas también pueden ser entendidas como disputas por lógicas del poder distintas, en este caso, entre el educador y las autoridades municipales.

\footnotetext{
${ }^{175}$ AHMMBB, 15 de julio de 1862.

${ }^{176}$ Anales de Educación Común, Volumen II, 1 de abril de 1860, Buenos Aires, n. ${ }^{\circ}$ 16, págs. 482-483.

${ }^{177}$ AHPBARL, Dirección General de Escuelas, 6138-32, Carpeta 2507-16-4-1857.

${ }^{178}$ Puiggros, A. op. cit., pág. 31.

${ }^{179}$ AHPBARL, Dirección General de Escuelas, Carpeta 2507, 6141-32.
} 
Poco tiempo después, en junio de 1857, Zambonini solicita a Sarmiento licencia para trasladarse a la Capital «...dado en ella por razón de mis infortunios domésticos con que esperaba que ese Departamento mira mis tan devastados servicios al frente de esta juventud ${ }^{180}$.

El preceptor invoca ante el Jefe del Departamento de Escuelas su descrédito y el abandono que dice sufrir frente a sus permanentes reclamos ante las autoridades de Buenos Aires.

Paradójicamente, un día después a su reclamo el preceptor recibe el reglamento solicitado fechado el 25 de febrero de 1857, es decir, cuatro meses después de redactado. Este reglamento hacía referencia a la conducta que debía observar un preceptor con «alumnos incorregibles». Zambonini confirma a sus autoridades haber dado lectura a sus alumnos del instrumento reglamentario con que ahora contaba, esperando tener éxito con el mismo.

No solo significaba para este educador un límite hacia la conducta de alumnos sino para establecer quienes deberían pagar y quiénes estarían exceptuados. El niño debe ser acostumbrado a ser «obediente». Dentro de la política pedagógica en este contexto histórico, el niño que no es obediente, es «incorregible» como lo llama Zambonini, o «malo». Debe adquirir el hábito de obedecer a padres y maestros.

Los alumnos que demostraban conocer el catecismo recibían un Manual Cristiano y de ejercicio cotidiano. El Preceptor por esta disposición estaba obligado a que los alumnos aprendan la instrucción para la confesión y comunión cumpliendo los mandatos de la Iglesia.

Estas prácticas escolares con el protagonismo de la Iglesia no son casuales. Los postulados educativos después de Caseros, si bien intentan una transformación en las practicas educacionales que buscaban fortalecer experiencias que se extiendan a los sectores más relegados, era evidente que resultaba romper el statu quo sostenido por el rosismo en la campaña «que reconocía la buena educación de la juventud en las Escuelas empleando sus Máximas ala de la Santa Religión...» ${ }^{181}$. Subyacen quiebres ideológicos y filosóficos que exploran nuevos proyectos alternativos con la permanencia del poder religioso por sobre las instituciones civiles en la campaña bonaerense resulta evidente. Las nuevas formas ideológicas liberales no dogmáticas inspiradas en los principios de los hombres que habían integrado la Generación del 37, que plantea una nueva modernidad político-educativa argentina, no alcanzan a penetrar en núcleos urbanos distantes de Buenos Aires, hasta después de la década del sesenta del siglo XIX ${ }^{182}$.

Los cuadros que se adjuntan permiten observar los contenidos que eran evaluables en la escuela de Patagones, la calificación y la dimensión en la premiación en la escuela de varones de Bahía Blanca

\footnotetext{
${ }^{180}$ AHPBARL, Dirección General de Escuelas, Carpeta 2507, 6142-32.

${ }^{181}$ AGN, 1830, C24, A9- n. ${ }^{4}$.

${ }^{182}$ Cfr. Galfione, M. C. «Lenguaje y política en Esteban Echeverría, Juan Bautista Alberdi y Francisco Bilbao», Cuyo. Anuario de Filosofía Argentina y Americana, Volumen 27, 2010, págs. 35-53.
} 
Relación de los alumnos de la escuela pública de varones del estado del partido de Patagones premiados el 26 de diciembre de 1858 por aplicación en sus clases respectivas de conformidad a su previo examen

\section{Clase octava}

\begin{tabular}{l|r|r|r|r}
\hline $\begin{array}{c}\text { Nombre y apellido } \\
\text { de alumno }\end{array}$ & $\begin{array}{c}\text { Lectura y } \\
\text { escritura }\end{array}$ & $\begin{array}{l}\text { Doctrina } \\
\text { cristiana }\end{array}$ & $\begin{array}{c}\text { Grámatica } \\
\text { castellana }\end{array}$ & Aritmética \\
\hline \hline Martínez Lorenzo & Sobresaliente & Idem & Idem & Idem \\
\hline Crespo Manuel & Sobresaliente & Idema & Idem & Idem \\
\hline Ávila Emiliano & Sobresaliente & Idem & Idem & Idem \\
\hline Crespo Bernabé & Sobresaliente & Idem & Idem & Idem \\
Guerrero Juan & Bueno & Idem & Idem \\
\hline Miguel P. & Bueno & & & Idem \\
Harris Adolfo & Bueno & & \\
\hline \hline
\end{tabular}

\section{Clase séptima}

\begin{tabular}{l|c|c|c|c|c}
\hline \hline $\begin{array}{c}\text { Nombre del } \\
\text { alumno }\end{array}$ & Lectura y escritura & $\begin{array}{c}\text { Doctrina } \\
\text { cristiana }\end{array}$ & Aritmética & $\begin{array}{c}\text { Gramática } \\
\text { castellana }\end{array}$ & $\begin{array}{c}\text { Calificación } \\
\text { final }\end{array}$ \\
\hline \hline Marcos Francisco & & & & & Sobresaliente \\
\hline Castro Liborio & & & & Bueno \\
\hline Crespo Alejandro & & & & Bueno \\
\hline Pelleras Federico & & & & Bueno \\
\hline Tomatis Andrés & & & & Bueno \\
Araque Hipólito & *Solo evaluado en estas materias & & & Bueno \\
\hline \hline
\end{tabular}

\section{Clase sexta}

\begin{tabular}{c|c|c|c}
\hline \hline $\begin{array}{c}\text { Nombre del } \\
\text { alumno }\end{array}$ & $\begin{array}{c}\text { Lectura y } \\
\text { escritura }\end{array}$ & $\begin{array}{c}\text { Gramática } \\
\text { castellana }\end{array}$ & $\begin{array}{c}\text { Calificación } \\
\text { final }\end{array}$ \\
\hline \hline Zambonini Nicanor & & & Sobresaliente \\
\hline Crespo Marcelino & & & Bueno \\
\hline Garcia Pedro & *solo en lectura & & Bueno \\
Guerrero Antonio & *solo en lectura & & Bueno \\
\hline \hline
\end{tabular}

\section{Clase quinta}

\begin{tabular}{l|c|c|c}
\hline \hline $\begin{array}{c}\text { Nombre del } \\
\text { alumno }\end{array}$ & Lectura y escritura & $\begin{array}{c}\text { Doctrina } \\
\text { cristiana }\end{array}$ & $\begin{array}{c}\text { Calificación } \\
\text { final }\end{array}$ \\
\hline \hline Tolosa, José & & & Sobresaliente \\
\hline Barajas, Francisco & $*$ Solo calificado en esta área & & Bueno \\
\hline Campo, Eusebio & & & \\
\hline Crespo, Teodoro & & & Bueno \\
\hline \hline
\end{tabular}


Clase cuarta

\begin{tabular}{l|c|c}
\hline \hline Nombre del alumno & $\begin{array}{c}\text { Lectura y } \\
\text { escritura }\end{array}$ & $\begin{array}{c}\text { Calificación } \\
\text { final }\end{array}$ \\
\hline \hline Mascarello Agustín & & Sobresaliente \\
\hline Avila José & & Bueno \\
\hline Olivares Sivilo & & Bueno \\
\hline Parras Calletano (sic) & & Bueno \\
\hline \hline
\end{tabular}

\section{Clase tercera}

\begin{tabular}{l|c|c}
\hline \hline Nombre del alumno & $\begin{array}{c}\text { Lectura y } \\
\text { silabeo }\end{array}$ & Calificación \\
\hline \hline Miguel Juan G. & & Bueno \\
\hline \hline
\end{tabular}

\section{Clase segunda}

\begin{tabular}{l|c|c}
\hline \hline Nombre del alumno & $\begin{array}{c}\text { Lectura y } \\
\text { silabeo }\end{array}$ & \begin{tabular}{c} 
Calificación \\
\hline Crespo Benito
\end{tabular} \\
\hline Real Eusebio & & Bueno \\
\hline \hline
\end{tabular}

\section{Clase primera}

\begin{tabular}{l|c|c}
\hline \hline $\begin{array}{c}\text { Nombre del } \\
\text { alumno }\end{array}$ & $\begin{array}{c}\text { Lectura y } \\
\text { primeras lecciones }\end{array}$ & Calificación \\
\hline \hline Zelaza Eduardo & & Bueno \\
\hline Ledesma Cirilo & & Bueno \\
\hline Barros José & & Bueno \\
\hline \hline
\end{tabular}

Fuente: AHPBA, DGE, Año 1858, Carpeta 2924, 6984-36.

El preceptor de Bahía Blanca adjunta la lista de los 12 niños que resultaron premiados en los exámenes celebrados el 18 de septiembre de 1868 .

\begin{tabular}{|c|c|c|}
\hline Dimensión de calidad & Nombre del alumno & Premio recibido \\
\hline $1^{\text {a }}$ Puesto & Piñeiro Antonio & Biblioteca de la Juventud \\
\hline $2^{\mathrm{a}}$ Puesto & Ânzoátegui Jacinto & Cuentos morales \\
\hline $3^{\mathrm{a}}$ Puesto & Miranda Celin & Estuche matemático \\
\hline $4^{\mathrm{a}}$ Puesto & Díaz Juan Francisco & Juanito \\
\hline $5^{\mathrm{a}}$ Puesto & Lezama Felipe & Una cartera y una estampa \\
\hline $6^{\mathrm{a}}$ Puesto & Bustos Anacleto & Un ángel de los alumnos y una estampa \\
\hline $7^{\mathrm{a}}$ Puesto & Iturra Juan & Una cartera y una estampa \\
\hline 8 Puesto & Casal Alejo & Una gramática y una estampa \\
\hline $9^{a}$ Puesto & Calvento Torcuato & Biblioteca de la Juventud \\
\hline $10^{a}$ Puesto & Zonza Sebastián & Una geografía \\
\hline $11^{\circ}$ Puesto & Ánzoátegui Teófilo & Vida de San Francisco \\
\hline $12^{\circ}$ Puesto & Ituarte Ceferino & Estampa \\
\hline
\end{tabular}

Fuente: AHMMBB, n. ${ }^{\circ} 49$.

Sixto Laspiur y Francisco Bozzano miembros de la comisión nombrada por la Corporación Municipal «para el examen de los alumnos de la Escuela de Varones de este pueblo á cargo del señor Preceptor Dn. Juan Ruibal...» han examinado uno a uno todos los alumnos en los diferentes ramos que abraza la 
enseñanza y en general hemos quedado satisfecho del estado próspero de esta escuela, bajo la ilustrada y asidua contracción de su digno preceptor

\begin{abstract}
...recordará que hace poco tiempo que el personal de la Escuela apenas se componía de unos quince niños en un estado lamentable de atraso y notará que hoy con la confianza que justamente ha inspirado el nuevo Preceptor en los padres de familia, ascendiendo a cuarenta y uno. Consagrados a la tarea eminentemente patriótica y humanitaria de la educación del Pueblo debemos esforzarnos porque el Pueblo mismo tome la parte que le corresponde en esta obra de civilización y progreso ${ }^{183}$.
\end{abstract}

Este informe elevado al presidente de la municipalidad Don Mariano Méndez, destaca que el aumento de niños en seis meses en la escuela. El director de escuelas Luis de la Peña destaca la «... la contracción del Preceptor — quien ha logrado duplicar el número de niños y a las autoridades de la municipalidad— ${ }^{184}$.

$\mathrm{Al}$ analizar el discurso de este nuevo Director General de Escuelas, supone una transformación de la mirada sobre el hecho educativo. Pensar históricamente el discurso social, nuevos campos científicos y filosóficos, con una mirada renovada del pasado, dando protagonismo a los actores educativos, como el maestro, el preceptor, autoridades locales, vecinos y las comisiones evaluadoras.

Le anticipa al presidente de la municipalidad de Bahía Blanca que el año anterior ha sometido al gobierno un proyecto de ley sobre enseñanza primaria, a la que considera el único «medio eficaz de propagar la educación por el concurso que todos los habitantes presenten a tan vital necesidad social».

«Es de esperar — dirá más adelante— Que nuestros legisladores se ocupen a fin de dar la sanción a una cuestión tan importante y que los ha ocupado hace ya dos años» ${ }^{185}$.

La formación de una sociedad disciplinada, remite a técnicas para garantizar el ordenamiento. Bajo la conceptualización de Foucault la disciplina es una táctica de poder, que hace que el ejercicio del poder sea lo menos costoso posible y su relativa invisibilidad ${ }^{186}$. La disciplina en el alumno implica una manera específica de castigar. La falta del alumno es un delito menor, que puede ser, no cumplir sus tareas. El castigo es siempre «correctivo», aunque el maestro diligente debe estar atento a las «correcciones» para obtener el respeto de sus alumnos.

${ }^{183}$ AHMMBB, 23 de septiembre de 1868.

${ }^{184}$ Nota: Este educador nacido en Buenos Aires en 1795, estudio en el colegio de San Carlos, doctorándose en la Universidad de Córdoba en filosofía y teología. Durante el gobernó de rosas tuvo que exiliarse y se desempeño como educador en Brasil y en Montevideo. En 1865 fue designado miembro del Consejo de Enseñanza pública. Mantienen una profusa correspondencia con Juan María Gutiérrez sobre temas de relaciones exteriores y de educación fundamentalmente durante la etapa que cumple como autoridad educativa de la provincia de Buenos Aires.

${ }^{185}$ AHMMBB, 22 de octubre de 1868.

${ }^{186}$ Cfr. Foucault, M. Vigilar y castigar. Nacimiento de la prisión, Buenos Aires: Siglo XXI, 2008, pág. 251. 
Según el testimonio del alumno Pita de Patagones el educador Luis De Marco, tenía «un arte especial para transmitir sus conocimientos, era un entusiasta por la profesión, al punto que siendo elemental su escuela con solo hasta $4^{\circ}$, él creó motu proprio el $5^{\circ}$ y $6^{\circ}, \ldots$ y los tomó a su cargo...» ${ }^{187}$.

Según sus palabras, varios alumnos que allí egresaron, pudieron ingresar al Colegio Nacional de Buenos Aires, a la Escuela Naval y al Liceo Militar. No obstante, recuerda que si bien enseñaba con placer, también se exasperaba con alumnos que mostraban dificultades en el aprendizaje o eran indiferentes.

En junio de 1871, una nota dirigida al jefe del departamento de escuelas Don Eduardo Costa, padres de niños que «asistían» a la escuela pública de varones adjunta exposiciones que comunican sobre «del maltrato que el preceptor de esta escuela ha tratado algunos niños...teniendo sus padres que ponerlos en una escuela particular...». A consecuencia de estas quejas, el Juez de Paz hizo comparecer al juzgado al Preceptor para prevenirlo de esta falta «...ala que espuso rasones (sic) que no justificavan (sic) su conducta...».

El juez de paz señala que se ha reunido en el municipio, y que sus autoridades tenían conocimiento de estos maltratos que el preceptor incurría con algunos niños «...y el mal uso que hacía con la Casa alquilando algunas piezas de ella a personas que no convenían al establecimiento» ${ }^{188}$.

Este documento estaría refrendado con la opinión Pita al afirmar que tanto De Marco como Galván eran maestros de «palmeta en mano» porque decían que la letra «con sangre entra». «Concurríamos a la escuela con verdadero gusto, pues había sabido hacerse apreciar — haciendo referencia a De Marco- a pesar del gran respeto y hasta miedo que le teníamos por la palmeta» ${ }^{189}$. La elección de este párrafo nos permite tomar un modelo interpretativo del discurso de Pita que refiere al valor y uso de las teorías educativas dentro de esa dimensión histórica.

De Marco, nacido en Roma, según el testimonio del alumno gustaba enseñar Historia, no dando las lecciones de memoria, hablando durante una hora con vehemencia y pasión.

El modelo educativo impuesto en esta etapa es entendido por Puiggrós como «instrucción pública». Un sistema educativo de desarrollo desigual, cuya modalidad es la lucha por la hegemonía de filosofías de la educación propias de un contexto socio-económico y político, reflejo del individualismo y del concepto de adaptación del individuo a una sociedad cambiante propia de la revolución industrial británica. Siguiendo el pensamiento de Paulo Freire, en una cultura letrada, el alfabetizado aprende no solo a leer y escribir, sino que instaura el mundo en el que él se humaniza. El hombre se redescubre y logra problematiza y descodificar críticamente al mismo ${ }^{190}$.

Los Anales de Educación fueron medios de difusión para maestros del pensamiento d Herbert Spencer, acercaba doctrinas positivistas y cientificistas, Sarmiento, Marcos Sastre, Mármol, Mitre,

${ }^{187}$ Ídem, pág. 51.

${ }^{188}$ AHCP, Año 1871, n. ${ }^{\circ} 265$, Folio 4, Caja 12.

${ }^{189}$ Pita, F. op. cit., pág. 54.

${ }^{190}$ Cfr. Freire, P. Pedagogía del oprimido, Buenos Aires: Siglo XXI, 1970. 
Somellera, Tejedor, Alberdi y Gutiérrez introducen nuevos criterios educativos, que responden según pro a un espiritualismo ecléctico.

Sarmiento, procura difundir en los Anales obras de otros importantes pedagogos que conoce en su misión diplomática a Estados Unidos (1865-68), como Horace Mann, promotor de la educación popular norteamericana Ralph Waldo Emerson y especialmente Herbert Spencer había publicado en Inglaterra obras como No Conformist (1842), Social Statics (1850) y Education, $(1861)^{191}$.

Parafraseando a Ezequiel Martínez Estrada, la educación era para Sarmiento una panacea, no porque fuera ingenuo sino porque estaba decepcionado. Enseñando a leer y a escribir descubrió el fondo humano incorruptible «bajo la corteza de las costumbres y del abandono de sus vidas» ${ }^{192}$. Las ideas de Sarmiento concuerdan siguiendo a este autor con los que concibieron una Argentina siempre futura, en el destierro.

\section{Justicia de Paz: prácticas jurídicas y educativas}

En todos los puntos anteriores hemos visto los vínculos y el protagonismo de los jueces de paz en la acción educativa, acompañando a los vecinos y a los comandantes de frontera, en las peticiones por la creación de escuelas o informando sobre la situación educativa de su jurisdicción.

La ley militar del 2 de julio de 1822 que completa la ley del 17 de diciembre de 1823, estipulaba el reclutamiento por «alistamientos voluntarios» o en caso de insuficiencia, por «contingentes». Este será el inicio de la práctica sobre reclutamiento de vagos y mal entretenidos. Bajo los principios político liberal de Rivadavia y Rodríguez habían establecido en el decreto del 19 de abril de 1822, que «los vagabundos vienen a ser un obstáculo real a los adelantamientos del país y una causa más que impida o retarde el complemento de la reforma general que se ha iniciado...» ${ }^{193}$.

Frente al modelo progresista ideado por Rivadavia, este personaje sin oficio, simplemente con las habilidades que le daba su destreza con el caballo, en el arreo o en el laboreo del campo, debía ser aprehendido. El castigo a quien fuera «aprehendido por vago» sería el destino al cuerpo del ejército que se estime más conveniente (art. $3^{\circ}$, Decreto citado).

Durante la etapa del gobierno de Rosas, no solo procuran la fortificación y la colonización de la frontera del sudoeste, sino una mejor administración de justicia ${ }^{194}$. Tal como afirma Díaz, el juez de paz «era el eje y centro de toda la administración de la campaña», procediendo a organizar un sistema de persecución de «desertores y vagos» ${ }^{195}$.

${ }^{191}$ Zinn, H. A people history of the United States, Boston: Harper Perenial, 1990, págs. 214-216.

${ }^{192}$ Martínez Estrada, E. Sarmiento. Meditaciones Sarmientinas. Los invariantes históricos del Facundo, Rosario: Viterbo, 2000, pág. 29.

${ }^{193}$ Prado y Rojas, A. Leyes y decretos..., Buenos Aires: Mercurio, 1877, pág. 297.

${ }^{194}$ Cfr. Decreto de creación del Juzgado de Paz de Bahía Blanca, en apéndice documental.

${ }^{195}$ Díaz, B. op. cit., pág. 98. 
Grupos que se contraponen y entremezclan, cada uno con sus derechos y deberes, con leyes que responden a necesidades propias de uno de los entes y donde el individuo solo, es difícilmente pensable.

Para Salvatore, el régimen político del rosismo instala definitivamente una república en la que los ciudadanos eligen a sus representantes y permiten que labradores y pastores faciliten según su discurso «un mundo rural estable y armónico». Uno de los componentes del discurso republicano rosista era la «defensa del sistema Americano», entendiendo que el miedo y castigo permitiría el acatamiento a la ley. Este autor sostiene que para retornar al orden y tranquilidad a pueblos y paisanos, no solo se requería de una constante información y difusión de las normas legales, sino la práctica común de leerles las consecuencias de incumplimiento de contratos de trabajo, de la deserción militar. Como una forma de aplicación de la pedagogía del terror, ocasionalmente, se hacía alguna ejecución pública que podría servir para crear el temor a la ley ${ }^{196}$. El terror y el desamparo eran la línea ambivalente entre el poder y la criminología, factores que estaban lejos de acercar estos «vagos» del mundo rural a un sistema escolar.

Producida la caída de Rosas pervivirá la organización judicial ideada durante la gobernación de Martín Rodríguez y basada en el proyecto de Castro, Castex y Valle.

Luego de la caída de Rosas, el gobernador Pastor Obligado en su mensaje del 1 de mayo de 1857 explica que los jueces de paz son «... el principal brazo de la administración en la campaña». Obligado sostiene que desde hace tres años el gobierno está abocado a reorganizar el sistema de defensa de fronteras, buscando dar seguridad a las depredaciones del indígena. Pero la inseguridad era moneda corriente para quienes la habitaban.

El gobernador entendía que esta antigua fortaleza era «base natural de toda operación que se emprenda en el desierto en escala mayor» ${ }^{197}$. Lógicamente el juez de paz de un puesto fronterizo tan alejado tendría mayor autonomía en razón de un contacto más escaso con las autoridades de Buenos Aires.

Las facultades civiles y penales que ejercían los convertían en dueños del destino tanto del gaucho o vago como de pequeños hacendados o propietarios en virtud de que debían dirimir desde crímenes y castigos hasta actos sucesorios. Reafirmando esta aseveración quien fuera gobernador de la provincia, Carlos D'Amico dirá:

Hasta el año 1878 la policía había estado entregada enteramente a los jueces de paz, que según la importancia del partido, hacían revistar de nueve a quince hombres, mandados por uno que titulaban sargento, y que dependían exclusivamente de aquel omnipotente funcionario".

Él los nombraba, él los destituía, él los castigaba, él los premiaba, él los mandaba, sin intromisión de nadie, sin reglamento, sin limitación, sin control. El uso o el abuso de la autoridad era cuestión de

\footnotetext{
196 Salvatore, R. Subalternos, op. cit., págs. 94-97.

${ }^{197}$ Mabragaña H. Los Mensajes. Historia del Desenvolvimiento de la Historia Argentina, Tomo III, Mensaje del gobierno del Estado a la Asamblea General Legislativa (1857), Talleres Gráficos Cía. General de Fosforos. (1895-1910).
} 
conciencia del juez de paz, porque su voluntad era ley ${ }^{198}$. Este juez de paz que retrata $D^{\prime}$ Amico y que presentaba el cepo en la entrada del juzgado para infundir temor o como simple advertencia para quien no quisiera obedecer y callar, era diferente para el gobernador Pastor Obligado, teniendo en cuenta dos contextos históricos diferentes.

A primera vista, el juez de paz representa la autoridad que combina el control moral y social de una población y de instituciones como la escuela que los fija en un espacio determinado y a un aparato de corrección y transmisión del saber. Consciente que la producción de saberes en los niños facilitaría a futuro determinada movilidad social, disciplina colectiva y cierta seguridad de su futura inserción en el aparato productivo y económico regional.

\subsection{El sumario como fuente de indagación educativa}

Existen diferencias fuentes de indagación histórica y cuando abordamos el grado de competencias intelectuales o de alfabetización de una población determinada nos topamos con la ímproba tarea de realizar un estudio cuando carecemos de datos concretos como son los que pueden aportar los censos, estadísticas o padrones. No obstante, es lógica la consideración que en las zonas de la frontera del sudoeste bonaerense aquellos que eran merecedores de consideraciones como «distinguidos vecinos», «o productores de conocimientos», en un contexto social de regiones o espacios periféricos de la provincia con una alfabetización precaria que los distanciaba del resto de la población.

En Carmen de Patagones, se observa la presencia de un grupo de vecinos, entre los que se encuentra el Comandante de Frontera, como analizamos, y aquellos que lo acompañan en las primeras peticiones escolares, una vecindad ilustrada como fue el caso de Ambrosio Mitre. El análisis de su discurso escrito hacia las autoridades de Buenos Aires deja entrever actuaciones verbales y métodos de estructuración lingüística más complejos ${ }^{199} \mathrm{Si}$ bien carecemos del sujeto parlante, la redacción de los sumarios nos permite descubrir leyes de construcción y formas que no era el común para el paisanaje.

La competencia penal otorgada a la justicia de paz y comisarios de campaña, el 15 de julio de 1857, les permitía resolver desde asesinatos a delitos menores. Por lo tanto, nuestro interrogante se centró en cómo determinar el nivel de alfabetización de quienes eran considerados «vagos o mal entretenidos»y aquellos en quienes tenían el derecho de juzgarlos. Para ello, analizamos diferentes sumarios de procedimiento penal.

${ }^{198}$ D’Amico, C. «Siete años en el gobierno de la provincia de Buenos Aires», citado en Rodríguez Molas, Historia Social del Gaucho, Buenos Aires: Maru, 1968, Apéndice, pág. 592.

${ }^{199}$ Este funcionario, designado ministro tesorero por el gobierno de Martín Rodríguez en Carmen de Patagones, nacido en Santa Lucía, Uruguay, había comenzado a estudiar en Montevideo concluyendo los mismos en Buenos Aires. No sólo fue padre de Bartolomé, sino de Emilio y Federico Mitre. Datos extraídos del Diccionario Biográfico Argentino de Enrique Udaondo, Buenos Aires: Coni, 1938. 
Dentro de las prácticas jurídicas procedimentales, pueden observar similares etapas a las actuales: En primer lugar el juez de paz cumple en la recepción de la denuncia verbal o escrita sobre el hecho delictivo ${ }^{200}$.

Como ejemplo podemos citar el siguiente sumario: Sixto Laspiur, juez de paz de Bahía Blanca, recibía así una denuncia:

Habiéndose dado noticia en este momento que son las nueve de la mañana, por parte verbal recibido del Teniente Alcalde Don José Zamora, que el cuatro del corriente cerca de oraciones, hallándose en su casa en el cuartel Costa de que entregado por el alféres(sic) Don Fernando Linares, acompañado de su hermano Martín Linares y dos piones, a Pascual Luque gravemente herido a consecuencia de una pelea que había tenido con varios individuos en el puesto de Amaro Díaz, a fin de averiguar este hecho, y si fuere criminoso, indagar quién o quiénes lo han ejecutado... ${ }^{201}$.

Como segundo paso, y en razón que el delito normalmente era cometido por peones o «vagos», quienes desconocían la práctica de la lectura o escritura, se daba lectura al delito y quienes ofíciaban como testigos, eran generalmente vecinos «respetables» que sabían leer y firmar. Estos vecinos ocuparán en el futuro cargos municipales o miembros de la justicia de paz. Otros, eran comerciantes o pequeños hacendados. Llamativamente, pudimos observar como los nombres de estos testigos que certificaban la declaración de gauchos o peones, se repetían en los diferentes sumarios de Bahía Blanca. Al respecto, como por ejemplo, la firma de un vecino bahiense y posteriormente juez de paz, Pedro Hugony aparece en forma reiterada certificando como testigo de analfabetos en diferentes causas penales.

Indudablemente, la circular del 20 de agosto de 1869, preveía o intentó paliar en sus recomendaciones las aparentes irregularidades de enjuiciamiento declarados vagos por el Código Rural en su art. $291^{202}$. El castigo se aplica ante la evidencia de ser «mal entretenido», «enviciado por la bebida», y en esta parcialidad de juicios, logramos observar la carencia de defensores. El jurado escuchaba la declaración

${ }^{200}$ Nicolasa Díaz, declara como testigo sobre el robo de paja de trigo al vecino Francisco Araque (conocido comerciante bahiense cuyo origen es de Patagones), siendo acusado «un tal Carro» que declara su inocencia firmando con una cruz. El juez de paz lo destina al servicio de las armas de la Guardia Nacional por el término de dos años. Firma, el esposo de la declarante, Mauricio Díaz. AHMBB, Doc. n. ${ }^{\circ} 002742,8$ de marzo de 1863. Sixto Laspiur, esposo de la maestra Ciriaca Palau, recibe la denuncia que se transcribe. AHMMBB, Doc. n. ${ }^{\circ}$ $003867,1869$.

${ }^{201}$ AHMMBB, Doc. n. ${ }^{\circ} 003867,1869$.

${ }^{202}$ La calificación de vago, aplicada a los que carecian de domicilio fijo y medios conocidos de subsitencia,... escapa a los alcances de este análisis que no pretende más que profundizar si existía por parte de quienes eran juzgados o castigados, las dimensiones de las penalidades que se basaban fundamentalmente en un desequilibrio en los niveles posibles de análisis, producto de quienes eran poseedores del saber, que lógicamente, los llevaba al respeto o rechazo de la autoridad, sin poder dilucidar su real dimensión. Es por ello, que el quiebre reflexivo, a mi entender, lo propone el poema del Martín Fierro, que retrata esta dualidad de la justicia de paz. 
testimonial y a través del relevamiento realizado en las causas sumarias penales del juzgado de paz de Bahía Blanca, en la mayoría de ellas, el reo carece de defensor, tal como lo afirmo anteriormente, procediendo el juez al final del procedimiento a la declaración de sentencia, normalmente condenado como vago. Solo pudimos comprobar un sumario con absolución del reo, de aquellos que consultamos en el Archivo Histórico Municipal de la Municipalidad de Bahía Blanca.

Otro factor que tuvimos en cuenta para colegir el grado de alfabetización de las poblaciones fronterizas, y en este caso, de los actores de la justicia de paz, fue quienes eran convocados como peritos.

El Dr. Parrot, único profesional que figura en el censo del partido de Bahía Blanca, en 1869, participa en el sumario que hace referencia al incidente probado por dos paisanos. Los datos que aporta este médico es una evidencia más sobre conocimientos científicos de la época, con una práctica discursiva que tiene regularidad y consistencia ${ }^{203}$.

...informo que las heridas son cuatro siendo una encima del «osoccipital» del cranium de las siguientes dimensiones, tres pulgadas de largo y tres líneas de profundidad causas por un arma cortante.

La segunda es situada encima del ojo derecho, lacerada e irregular en forma...y dos líneas de profundidad causadas por un arma de igual clase.

La tercera es situada en la parte inferior abajo del brazo derecho... Unas contusiones pequeñas en varias partes del cuerpo, que da a creer que el herido ha sufrido golpes con un arma contundente.

La hemorrage (sic) (en las heridas de la cabeza) abundante en consequencia (sic) de la ruptura de las «arterias temporales»(22).

El documento muestra claramente el anacronismo en grupos sociales con mayoría sin ágrafas, donde resulta indudable funciones de cierta especialización y ocupación de individuos que surgen como «agentes especializados». La división de trabajo en sociedades rudimentarias como esta favorece la legitimación y de nueva estratificación social de quienes son poseedores del saber universitario.

\subsection{El saber como instrumento de construcción de orden y poder}

Existe una relación entre el saber de los jueces de paz y el poder que ellos detentaban. Mantienen una relación con sus pares, demostrado en los diferentes sumarios con la alternancia de idénticos vecinos en la firma de los sumarios. A pesar que sus conocimientos (en el campo intelectual) no integran la intelligentsia del espacio de frontera, puede afirmarse que son "hombres de conocimiento" en lo legal. Podemos sostener que es una profesión que facilitó la construcción no sólo del orden en la frontera, sino del poder político en el futuro.

${ }^{203}$ AHMBB, censo y estadística de Bahía Blanca, 15 de septiembre de 1868.

18) AHMMBB, Doc. n. ${ }^{\circ} 003882,6$ de diciembre de 1869. 
La indagación de comunicaciones y sumarios judiciales que obran en el Archivo General de la Nación, nos permitió analizar partes trimestrales y respuestas a sus solicitudes por parte del poder central así como la aplicación y ejecución indicios que nos permitieran verificar la veracidad de su argumentación. Analizamos las penas a «vagos» y «mal entretenidos» partes trimestrales y las respuestas a solicitudes de filiación, o la ejecución de penas a «vagos» entre 1833 hasta 1850.

Curiosamente, encontramos que los rasgos caligráficos de todos estos informes son idénticos a pesar de los cambios de autoridades en la justicia de paz. Si bien la caligrafía es la misma, se produce una notable variación en las firmas y en el color de la tinta, que incuestionablemente era diferente ${ }^{204}$. Otro prueba de lo aseverado lo constituye el parte del juez de paz interino Mauricio Díaz por el fallecimiento del juez de paz José María Hidalgo, firmando la aplicación de pena al desertor del Regimiento 5, Manuel Sansaman, el 6 de octubre de 1849, no existiendo correspondencia entre su firma y la caligrafía del escrito ${ }^{205}$.

En la filiación del desertor José Clavo Otarola, en mayo de 1849, perteneciente al Regimiento 5 de Caballería de Campaña en Indio Rico, el juez de paz de Bahía Blanca, informa que el detenido «sabe leer y escribir» y luego de dar los detalles que obran en las filiaciones de esta época, afirma que Otarola «que ha prestado servicios a la Santa Federación desde $1829 \ldots$..., «no ha querido prestar su firma» ${ }^{206}$. En el mismo expediente, obran documentos de Santos Lugares con fecha 26 de mayo de 1850, interrogando nuevamente al mismo individuo, que dice ser desertor y afirma no saber leer y escribir. Dado que su detención se había motivado por ser encontrado por el juez de paz de Bahía Blanca con un pase falso, se lo interroga quien le ha entregado dicho pase:

Este individuo al decirle firmar esta agregación y preguntado también cuál había sido el motivo porque no había querido hacerlo en la antecedente clasificación, a expuesto que no ha firmado porque no sabe escribir ni leer, de lo que se infiere que haya sido el mismo el que ha hecho el pasaporte falso y es adjunto, y no el referido Luis Sosa como él afirma... ${ }^{207}$.

Parafraseando a Salvatore eran escasos los desafíos abiertos hacia la autoridad de los jueces de paz, bajo conceptos criminológicos que abarcaban tipologías sicológicas, sociales y morales ${ }^{208}$. El tamaño, la dimensión de la escritura, la armonía o el desorden del grafismo de los jueces de paz en los informes

\footnotetext{
${ }^{204}$ Por ejemplo analizado el documento del 18 de octubre de 1839 José María Acosta informa sobre la aprehensión de José Gregorio Quiroga a quien se le ha colocado una barra de grillos porque «debía contener cualquier desorden y muy especialmente en las cajas de trato donde comúnmente se originan...», firmando con rasgos totalmente diferentes a la letra que ha confeccionado este documento. AGN, División Gobierno Nacional, Juzgado de Paz de Bahía Blanca, 1831-52, Sala 10, C.20, A10, n. ${ }^{\circ} 4$.

${ }^{205}$ AGN, División Gobierno Nacional, Juzgado de Paz de Bahía Blanca, 1831-52, Sala 10, C.20, A.10, n. ${ }^{\circ} 4$,

${ }^{206}$ AGN, División Gobierno Nacional, Juzgado de Paz de Bahía Blanca, 1831-52, Sala 10, C.20, A.10, n. ${ }^{\circ} 4$.

${ }^{207}$ AGN, División Gobierno Nacional, Juzgado de Paz de Bahía Blanca, 1831-52, Sala 10, C.20, A.10. n. ${ }^{\circ} 4$.

${ }^{208}$ Cfr. Salvatore, R. op. cit. México: Gedisa, 2010, págs. 116-117.
} 
sumarios contrastan con los datos de los paisanos cuya firma es solo una cruz que indicaría que el detenido no sabía firmar haciéndolo un testigo por él ${ }^{209}$.

El examen de la producción sumarial a los fines metodológicos nos ha permitido analizar un agrupamiento jurídico social más homogéneo que conforman las instituciones que dan significado a la justicia y a la legalidad en la frontera frente al campesinado y al gaucho, vago o mal «entretenido». Ellos son un reflejo de prácticas jurídicas que dejan traslucir interpretaciones legales que pretendían la rápida resolución de los conflictos, obviando derechos y fijando patrones de estratificación social marcadas entre quienes leen y quienes carecen o desconocen el acto de leer y escribir.

El discurso pedagógico oficial marcaba la preeminencia de los denominados por Puiggrós, normalizadores laicos, quienes divididos en varias fracciones sostuvieron la educación laica y estatal en diferentes historias regionales del país. La escolarización formaría al ciudadano — siguiendo la concepción sarmientina - rescatándolo de la «barbarie».

A pesar de ese modelo se desdibuja en el juez de paz quien ejerce el poder judicial de una aldea. Su funcionamiento, como la escuela, supone una disciplina y control de los individuos. Ese control escapa a las reglas éticas de su discurso, al firmar y dar por comprendidos sumarios a quienes carecían de saberes. Es una forma de control social que marca en la superficie la existencia de penas y castigos.

El poder económico — sumado al político y judicial - permitirá participar en los estratos sociales más altos y definir la escolarización de una región, construcción de escuelas así como eran las comisiones de evaluación de alumnos y docentes. Tal como lo sostiene Foucault, «poder y saber» están profundamente enraizados.

Durante mediados del siglo XIX, nuevas formas de producción ante la existencia de un nuevo Estado Nacional, que implicaba nuevas formas de concentración de recursos materiales y un incipiente proceso de desarrollo capitalista. Esta nueva realidad económica, plantea nuevas formas burocráticas-estatales que exigirían la conquista del poder con instrumentos de regulación social que hasta ese momento estaban representados por la Iglesia.

En estas zonas de nueva frontera, en los pueblos de campaña, el control de la justicia de paz de instituciones educativas facilitó la existencia de configuraciones sociales distintas: fue instrumento de sujeción del educando y de distribución de los beneficios en sectores sociales elegido como clase dirigente para recibir los beneficios de la educación. El listado de los alumnos que concurrían así lo prueban.

\section{Los curas vicarios castrenses}

En el Río de la Plata, en el período tardo colonial y principios del siglo XIX, se produce un fenómeno social: el reclutamiento de miembros de la Iglesia ante la contradictoria abundancia de clérigos y escasez

\footnotetext{
${ }^{209}$ Sumaria Información levantada contra José Martínez acusado de rapto de la joven Isidora San Román. Si bien
} la joven raptada sabe firmar, no lo puede hacer su raptor. AHMMBB, Doc. n. ${ }^{\circ}$ 002893, mayo 20 de 1862. 
de párrocos. Como lo demuestra Roberto Di Steffano, jóvenes porteños que constituían los hijos mayores de familias no adineradas abrazaron el celibato ante la posibilidad de recibir una mejor instrucción que los convirtiera en las personas ideales para administrar los bienes de sus familiares ${ }^{210}$. Existía una desproporción numérica entre los clérigos del mundo urbano y los del mundo rural, dada la escasa atracción que este último ofrecía a sus intereses, como por ejemplo desempeñar tareas didácticas en colegios o instituciones escolares.

En la ciudad los cuarteles y hospitales comienzan a requerir de capellanes. Pero es a partir de 18061807, se produce un proceso de militarización que da lugar al surgimiento de los curas vicarios castrenses. A pesar del crecimiento de curatos, la campaña permanece desprovista de religiosos, siendo la lejana Carmen de Patagones una de las primeras beneficiarias.

En Patagones, hubo tres iglesias parroquiales. La primera fue la capilla del Fuerte construida en 1780 siendo su sacerdote el padre Pablo Savino. La segunda la hizo edificar el vecino Bernardo Bartruille. Allí se le dio sepultura al donante, pero fue en la tercera iglesia construida en 1885, donde hoy descansan sus restos. Este vecino maragato, simpatizante rosista, había hecho constar en su testamento que se debería fundar una cofradía de ánimas y una capellanía. Bartruile, proveniente de Galicia, integraba el grupo de familias fundadoras dejando sentado además en esta testamentaria que se debería construir una escuela para ser entregada a Trinidad Zenteno, donde los niños aprenderían «Doctrina Cristiana». Al vecino Juan José Rial le cedía una casa para una escuela ${ }^{211}$.

Otra señal de interés de la iglesia por el curato de Carmen de Patagones queda demostrado en las instrucciones que en 1815 el futuro obispo Mariano Medrano dio para el fomento de la educación pública en Carmen de Patagones y el envío gratuito de material para la escuela para ser distribuido entre «la gente pobre» ${ }^{212}$.

Definiendo los textos como actos del habla, podemos comprender en el contexto en que José Juan

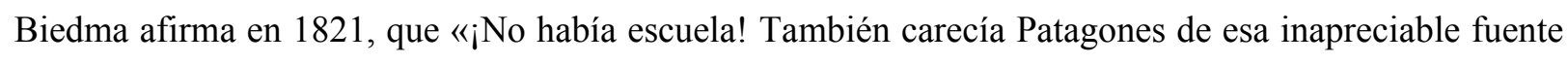
de civilización de que gozan los indios arrancados a la barbarie por los misioneros». Biedma pone énfasis que la acción que desarrollaba el capellán y cura propietario castrense presbítero Fray Mariano José de la Cruz, de la orden betlhemita, no era la esperada por los pobladores maragatos ${ }^{213}$.

En el período post revolucionario se produce una renovación ideológica en los sectores intelectuales porteños principalmente, con claros visos de secularización estatal, que quedaban expresados en las aulas y en el periodismo local. Las ideas liberales y la llegada de nuevas confesiones religiosas afectaron sensiblemente la incorporación de curas para la campaña. Las reformas religiosas de Rivadavia y la

${ }^{210}$ Di Steffano, R. «Abundancia de clérigos, escasez de párrocos: Las contradicciones del reclutamiento del clero secular en el Río de la Plata (1770-1840)», Boletín del Instituto de Historia argentina y americana Dr. Emilio Ravignani, 3a serie, 2do semestre de 1997 y 1 de 1998, Facultad de Filosofía y Letras: Fondo de Cultura Económica, págs. 33-59.

${ }^{211}$ AHCP, Testamentaria de Bernardo Bartruille, 12-4-1839.

212 Biedma, J. J. op. cit. pág. 467.

${ }^{213}$ Biedma, J. J. op. cit., págs. 466-67. 
incorporación de jóvenes en los cuadros militares de las guerras de la Independencia, que buscaban nuevas formas de ascenso social que redujeron en número el clero secular.

El cura vicario castrense es un nuevo actor que incorpora las milicias y el ejército como agente transformador que acompaña a los hombres de armas y a su vez al rescate de «almas» construyendo una relación vincular más cercana a los soldados y sus familias que a los estratos sociales más postergados como artesanos, labradores, peones, migrantes, mujeres.

Haciendo uso del concepto de Skinner en referencia al «contexto», existen nuevas convenciones a nivel internacional que surgen en la iglesia a partir de la de la segunda mitad del siglo XIX, comenzó una amplia actividad misionera, naciendo nuevas asociaciones sacerdotales que competían en lo espiritual con el impulso y labor llevada a cabo por las iglesias protestantes ${ }^{214}$.

El Syllabus de 1864 reflejó no solo cuestiones de fe sino ideas de una época. La Congregación Propaganda Fide acentúa la naturaleza misionera de la Iglesia, fortaleciendo la formación de sacerdotes para misiones que tuvieran especial contacto con indígenas y/o pueblos originarios en distintos territorios del mundo. En nuestro caso particular, el mayor énfasis se puso en la Patagonia. Esta acción misionera que pretendía la Iglesia Católica competía en lo espiritual con el avance de las misiones protestantes. En 1865, Mariano Acosta desde el ministerio de Gobierno, le informa y pone a conocimiento al presidente de la municipalidad de Patagones sobre el desembarco en ese puerto «de varios misioneros protestantes» ${ }^{215}$.

De ellos se desprenden nuevas convenciones lingüísticas como el énfasis en el término «cristiano» que se lee en los documentos de la época. Ello implicaba la realización de la obra pastoral por parte del cura a través del bautismo al indígena y la designación de un nombre hispano, sin identificar a que etnia pertenecían. Estos curas vicarios incorporaban a la soldadesca de las guardias militares a muchos de estos «indios amigos», quienes quedaban en carácter de «enganchados».

El cura actúa siguiendo la premisa de Vovelle como «intermediario cultural», al introducirse en lo popular como «mensajero de las almas» y como activo difusor del saber. Su mensaje religioso tendía a cumplir funciones sacramentales, que demuestran, por otra parte una mirada parcial y fragmentada de esa cultura desconocida, como puede observarse en el siguiente documento:

Expone S.E. el Cavo (sic) de Blandenguez, indio nombrado al Sagrado Bautismo Felipe y pasarlo (¿) es el apellido de S.E. de Rosas en la Estancia del Pino... cuando S.E. por Santa Fe que enganchados por dos años, corre en el quinto año y medio de Servicio militar a favor de la Patria Argentina, que en cuyo año siendo bautizado, se casa también en santo matrimonio con una yndia(sic). Su mujer fue bautizada por esposa en los meses de sus pasiones de este año, como ha debido en los honrosos de Bautismo y de matrimonio de esta Parroquia de Bahía Blanca ${ }^{216}$.

${ }^{214}$ Cfr. Palti, E. J. Giro Lingüístico e historia intelectual, Quilmes, Universidad Nacional de Quilmes, 1998, págs. 28-33.

${ }^{215}$ AHCP, año 1862, Expte. N. ${ }^{\circ} 150$, F.3, Caja 3.

${ }^{216}$ AGN, División Gobierno Nacional, Juzgado de Paz de Bahía Blanca, 1831-1852, Sala X, C20-A 10, n. ${ }^{\circ}$. 
El análisis de documentos del Archivo Histórico de Bahía Blanca, como la «Relación de sujetos afectos por malones», del Juzgado de Paz, son pruebas del cambio de nombres o apellidos «españoles» a determinados individuos quienes no perdían en esta relación su calificación de «indios»o «capitanejos» ${ }^{217}$.

Recién a partir del gobierno de Martín Rodríguez, con la expansión territorial en la frontera surgen las primeras figuras de curas que acompañaban a las milicias. Estos, tenían una particularidad: en un primer momento mantiene vínculos más estrechos con miembros de cuadros militares, sus familias y con posterioridad, consolidan su apostolado misional con los aborígenes. Poco a poco, estos curas llevaron a cabo una política diferente menos agresiva al indígena con el objetivo de ganar la paz con menor violencia, sin que dejaran de tener un carácter militar, en cuanto etimológicamente, por esta designación quedaban vinculados a la vida y al campamento militar. Según los documentos relevados eran llamados «capellanes del ejercito».

En Bahía Blanca, el nombramiento de un capellán se realizó en la campaña de Rosas, más específicamente en julio de 1834, cuando se dispone que la población cuente con «un capellán castrense» ${ }^{218}$ El presbítero Juan Bautista Bigio, italiano, enseñaba a leer a algunos niños hijos de oficiales de la guarnición, cumpliendo «el precepto cristiano de enseñar al que no sabe» ${ }^{219}$. Este cura genovés había sido designado «cura castrense» por el doctor Don Mariano Medrano y Cabrera, obispo de Buenos Aires. Logró bautizar a la población infantil y adulta y consiguió legalizar «uniones ilegítimas».

Entre 1837 a 1852 toma posesión de esta parroquia colocando la imagen de la Virgen Nuestra Señora la Merced, «regalada por la Señora Regina Masini y traída en el buque del Capitán Santiago Dasso» ${ }^{220}$. Aquí podemos nuevamente constatar nuevamente el permanente vínculo entre los vecinos de Patagones, como era la familia Dasso, con Bahía Blanca.

En 1842 el Pbro. Aquarone fue nombrado cura de Patagones permaneciendo la población de Bahía Blanca sin sacerdote hasta la designación de otro genovés el cura vicario Miguel Marchiano, actuando también como teniente del cura de Patagones hasta 1853.

El 25 de agosto de 1853, Lorenzo Torres del ministerio de Gobierno, le comunica al juez de paz de Patagones que «capellán castrense y cura vicario de Patagones»...«en vista de las poderosas y atendibles razones en que se funda el pedido» remueve del cargo a Nicolás Aquarone ${ }^{221}$.

La presencia de curas provenientes de Italia fue un fenómeno que tomó mayor cuerpo a partir de 1856 y que estuvo vinculado al proceso inmigratorio por una lado y por otro a la presencia de la Legión Agrícola Militar no solo en Bahía Blanca, sino también en Patagones. Albino Bracco, Salvador Passante, Juan Rossi, Sinforiano Gamallo, Jose Mendi, Francisco Oraro y el teniente cura José Arosa quien entrega la parroquia de Patagones a los Salesianos.

${ }^{217}$ Cfr. González Coll, M. M., op. cit., Anexo n. ${ }^{\circ} 22$.

${ }^{218}$ AGN, Sala X, 24-6-6.

${ }^{219}$ Reyna Almandos, op. cit., pág. 34. Esta afirmación de este autor fue tomada por el libro del Centenario de la Nueva Provincia, no pudiendo probar la misma en la documentación analizada.

${ }^{220}$ Centenario de Bahía Blanca, Homenaje de La Nueva Provincia, op. cit., págs. 673-674.

${ }^{221}$ AHCP, Año 1853, Expte. n. ${ }^{\circ}$ 38, Fojas 20, Caja n. ${ }^{\circ} 1$. 
Estos curas vicarios aplicaron en su formación los principios pastorales establecidos por Segurola: en sus prácticas el cura se involucra en el proceso de aprendizaje asistemático y portavoces de necesidades de higiene y salud de la población. Prueba ello, la solicitud del cura de Patagones de la vacuna antivariólica para la población ${ }^{222}$.

Durante el gobierno de Pastor Obligado, el Obispado, el 13 de mayo de 1853 da instrucciones a la justicia de paz para que, «debiendo hacerse el juramento de la Constitución del Estado de Buenos Aires por todos los empleados de la administración, por las demás personas a quienes comprende el decreto del Gobierno del primero del presente mes de mayo...se comisiona al Juez de Paz para que reciba dicho juramento al Capellán Castrense de ese Partido» ${ }^{223}$. El acta sería firmada por el Juez de Paz y el Capellán.

Se inicia a partir de este momento un proceso de regulación de la actividad educativo-religiosa por parte del estado de Buenos Aires. El 2 de febrero de 1856, el gobernador Obligado y Valentín Alsina, remiten a los juzgados de paz de la campaña un «Reglamento para las relaciones entre las Municipalidades y los curas de campaña en lo relativo al culto». Nuevas estrategias pedagógicas invaden un espacio político donde se observa un diseño del sistema educativo que comienza a reducir la influencia de la Iglesia en la educación. Si bien en la campaña no existieron fuertes antagonismos entre católicos y liberales, El reglamento permite ver los primeros pasos hacia la secularización educativa. Surgen conflictos entre los curas con los jueces de paz o con los intendentes ${ }^{224}$. El reglamento concedía atribuciones a las municipalidades para la remoción de los párrocos, previo recurso al obispado. De igual manera podía la autoridad municipal controlar las obligaciones que le cabían al cura.

Este documento jurídico marca un quiebre sobre la precisa situación de la iglesia y el clero en el estado de Buenos Aires. Es el inicio de la reivindicación del poder gubernativo del Estado, de su hegemonía en la educación popular y la palpable búsqueda por subordinar al clero.

A partir de la designación de Sarmiento como jefe del departamento de escuelas, los curas - como hemos visto - cumplían funciones en las Comisiones Evaluadoras de las Escuelas Públicas que se realizaban a los niños a fin del año lectivo en Doctrina Cristiana.

En 1862, Manuel Pazos a cargo del departamento de escuelas informa que se tomará examen público los primeros días de Cuaresma a los niños de escuelas primarias con el Catecismo de la Doctrina Cristiana $^{225}$. El examen lo rendían los alumnos que pertenecían a la sección primera o superior de Doctrina «estando invitados a presenciar las familias y público en general». Se exigía el conocimiento del «Catecismo de Astete» o aquellos que fueran adecuados a juicio del cura párroco. El Departamento de Escuelas distribuiría en señal de aprobación un «Manual del Cristiano o ejercicio Cotidiano».

${ }^{222}$ AHPBA Ricardo Levene, Año 1834, Carta del maestro Manuel de la Hoz y del Cura de Patagones, Notas: 1008, n. ${ }^{\circ} 14$.

${ }^{223}$ AHCP, Año 1854, Expte. n. ${ }^{\circ} 44$, F. n. ${ }^{\circ} 14$, Caja 1.

${ }^{224}$ AHCP, Según Expdte. n. ${ }^{\circ}$ 241, del 2-9-1869 el cura párroco de Patagones increpa al Juez de Paz por la desatención en la instrucción religiosa. En 1870 idéntico conflicto surge entre el Cura con el Presidente de la Municipalidad, Expte. n. ${ }^{\circ} 247,14$ de marzo de 1870.

${ }^{225}$ AHMBB, 15 de julio de 1862. 
Los preceptores — por su parte - instruían a los alumnos para la confesión y la comunión; y el cumplimiento con el segundo y tercer mandamiento de la iglesia. Una vez realizada esta labor le cabía al preceptor la obligación de remitir al departamento de Escuelas y con la firma del párroco los nómina de alumnos que se hubieran confesado y comulgado, especificando lo de la primera comunión. Los exámenes de Doctrina Cristiana no eximían a los alumnos de sus obligaciones con la escuela pública.

Podemos anticipar algunas conclusiones en lo referente a los curas de la frontera: en tanto se produce el avance hacia el sudoeste del territorio bonaerense, ellos permanecen vinculados casi en forma estricta a los mandatos militares. Mantienen una ritualidad que no era ajena a los acontecimientos políticomilitares del Río de la Plata. Tal como sostiene Pelagatti ejercían la cura de almas del ejército y desarrollaban litúrgico-sacramentales en los espacios donde se movían ${ }^{226}$. En el caso especifico del sudoeste bonaerense, se puede constatar la preeminencia de curas de origen italiano que responde a las urgencias externas de la Iglesia Católica ante contexto internacional frente al avance de misioneros protestantes. Su clara participación en las prácticas y doctrina educativa —a pesar de políticas liberales que los excluían - los posicionaron como referentes intelectuales de los dos centros urbanos analizados.

\section{Conclusión parcial}

En este capítulo buscamos identificar y esclarecer las prácticas educativas llevadas a cabo por los diferentes actores como los milicianos, comandantes de frontera, educadores femeninos y masculinos, jueces de paz y curas vicarios, para poder diferenciarlas. Las prácticas educativas y sociales son la pieza maestra de este armazón.

En dos centros urbanos se pueden distinguir diferentes y hasta opuestas formas de educar.

La praxis educativa indica en primer término cómo el espacio no fue ajeno a la construcción del poder y la estructuración del saber, en forma especial en los cuadros militares. El componente social de los mismos fueron diferentes en Patagones y Bahía Blanca. En el primero, podemos anticipar que existe una organización social de mayor horizontalidad que facilita la modificación social entre cuadros militares y pobladores. En el segundo, la escolarización cumple una función de regulación social ante una sociedad donde la población militar es mayor por sobre la civil. Y serán los «de la tropa» quienes reciban mayores beneficios de escolaridad. Esto genera una sociedad de mayor verticalidad en virtud que era el militar el poseedor de saberes conformando una intelectualidad marcada por tener mayor grado de escolaridad. Esta situación se va quebrando parcialmente hacia la llegada de la Legión Agrícola Militar, al ser una inmigración que mantiene valores de armonía inter-grupal en base a su jerarquía y su formación como expertos o intelectuales.

La praxis pedagógico educativa de niños y niñas en una zona de frontera es claramente diferente ante valores prevalente como autonomía y obediencia. Por momentos aparenta responder a los ordenamientos

${ }^{226}$ Pelagatti, O. I. «Los capellanes de la guerra. La militarización del clero en el frente oeste de la revolución rioplatense», en: Bragoni B. y Mata, S. (comps.) Entre la colonia y la república. Insurgencias, rebeliones y cultura politica en América del Sur, Buenos Aires: Prometeo, 2008. 
del poder central, debe adecuarse a problemáticas ajenas al resto del territorio bonaerense. Ellas eran dimensiones como la distancia del poder, la escasez de material didáctico, edilicio y la incertidumbre que generaba la discontinuidad en la permanencia de educadores.

La educación facilitó la formación de redes familiares, alianzas matrimoniales entre familias fundadoras, educadores, comerciantes, que llegaban a constituir cierta notabilidad en ambos centros urbanos.

Tanto los comandantes como los jueces de paz fueron actores que construyeron poder a través del saber y además generaron transformaciones educativas específicas en cuanto a la jerarquía social y política que cumplían frente a las autoridades centrales.

En cuanto a los curas vicarios si bien existió cierta autonomía diferencial en su concepción educativa, fueron actores precisos en su participación en las Juntas evaluadoras de las escuelas. Sin llegar a construir el poder que la Iglesia logra en otros ámbitos bonaerenses, tuvieron los instrumentos aptos para el dominio de saberes acorde a su doctrina eclesiástica. 


\section{Apéndice n. ${ }^{\circ} 1$}

Datos tomados de Crónica histórica del río Negro. Biedma, J. J. (1879)

Individuos elegidos para la expedición de Juan de la Piedra y Antonio de Biedma

\begin{tabular}{|c|c|}
\hline Oficiales de caballería & 4 \\
\hline Hombres de artillería & 20 \\
\hline Hombres de infantería & 100 \\
\hline Capellanes & 4 \\
\hline Herreros & 2 \\
\hline Cirujanos & 3 \\
\hline Sangradores & 4 \\
\hline Carpinteros de blanco & 2 \\
\hline Aserradores & 2 \\
\hline Albañiles. & 2 \\
\hline Maestros de hacer ladrillo y texa & 2 \\
\hline Herreros & 2 \\
\hline Panaderos & 2 \\
\hline Faroleros & 1 \\
\hline Individuos para atenciones de la hazienda & 2 \\
\hline Lenguaraces & 3 \\
\hline Mujeres negros y niños & 70 \\
\hline
\end{tabular}




\section{Apéndice ${ }^{\circ}{ }^{\circ} 2$}

Las cuatro divisiones españolas que se distribuyeron la tarea de demarcación de límites, según oficio del intendente de Guerra y Real Hacienda Franscisco de Paula Sanz (26 de noviembre de 1783) contaban con solo Comisarios a cargo de cada partida, sino con personas encargadas de atender a la curación de enfermos y la asistencia espiritual a cargo de los capellanes.

\begin{tabular}{c|l|l|l|l}
\hline \hline Partida & \multicolumn{1}{|c|}{ Comisario } & \multicolumn{1}{c|}{ Capellán } & \multicolumn{1}{c}{ Cirujano } & \multicolumn{1}{c}{ Sangrador } \\
\hline \hline Primera & $\begin{array}{l}\text { Comisario Ppal. Capitán } \\
\text { de Navío José Varela } \\
\text { Ulloa }\end{array}$ & Manuel de la Mata & Juan de Molina & José Antonio de Segovia \\
\hdashline Segunda & $\begin{array}{l}\text { Comisario y primer } \\
\text { Comandante Diego de } \\
\text { Alvear }\end{array}$ & Bernardo Fontánez & Félix Pineda y Morillo & Gregorio Martínez \\
Tercera & $\begin{array}{l}\text { Comisario y Cap. De } \\
\text { Fragata Félix de Azara }\end{array}$ & Antonio Miguel Arcos y Mata & José Martí \\
Cuarta & $\begin{array}{l}\text { Comisario y Te. de } \\
\text { Navío Juan Francisco } \\
\text { Aguirre }\end{array}$ & Domingo Aristegui & Antonio Cardoso & Domingo Carrera \\
\hline \hline
\end{tabular}




\section{Apéndice n. ${ }^{\circ} 3$}

\section{Cirujanos y sangradores}

\begin{tabular}{|c|c|c|}
\hline Aguilera, Manuel & Cirujano & $27-2-1782$ \\
\hline Aymar, Guillermo. & Cirujano. & $10-8-1780$ \\
\hline Cavallero, Juan Antonio & Sangrador & $9-2-1785$ \\
\hline Conde Felipe Alonso & Sangrador & 6-8-1781 \\
\hline Faya, Pedro & Cirujano & $30-7-1808$ \\
\hline Garrido, Diego & Cirujano & $26-11-1780$ \\
\hline Lamela, Francisco & Cirujano & $10-6-1783$ \\
\hline Maestre Juan & Sangrador & $10-7-1804$ \\
\hline Monto, Vicente & Sangrador & $27-2-1782$ \\
\hline Pavon, Martín & Cirujano & $27-2-1782$ \\
\hline Unjidos (Ujidos), Jose & Sangrador & $27-4-1791$ \\
\hline
\end{tabular}

Fuentes documentales: AHPBA Ricardo Levene: Lista que comprende los Asientos de los Empleados en el Establecimiento del Río Negro, Costa Patagónica, Año 1778 y «Datos relevados» de Cignoli, F. op. cit., págs. 99100. En este último caso, seleccionamos a cirujanos y sangradores establecidos en el «Establecimiento del Río Negro o Fuerte del Carmen». 


\section{Apéndice n. ${ }^{\circ} 4$}

Capellanes: Establecimiento Río Negro y Fuerte del Carmen (1780-1816)

\begin{tabular}{|c|c|c|}
\hline Acosta, José & Capellán Estab.Río Negro (Patagonia) & $6 / 12 / 1805$ \\
\hline Arias, Miguel & Capellán Estab. Río Negro & $6 / 2 / 1798$ \\
\hline Butierres, Tadeo & $\begin{array}{l}\text { Capellán del fuerte de Nstra.Sra. del Carmen de } \\
\text { Patagones }\end{array}$ & $29 / 9 / 1783$ \\
\hline Chavarria, Esteban & Capellán Estab.de Río Negro & $6 / 2 / 1798$ \\
\hline Gomez, Pedro & Capellán Población Río Negro (Patagonia) & $7 / 8 / 1780$ \\
\hline González, Migul & Capellán Establ. Rio Negro. & $5 / 9 / 1800$ \\
\hline Guzmán, Hipólito & Capellán población Rio negro & $28 / 7 / 1788$ \\
\hline Guzmán, Pantaleón & Capellán Población Río Negro & $\begin{array}{r}\text { 28/6/1787. Muere } \\
\text { R.N. en } 1797\end{array}$ \\
\hline Martínez, Pedro & Capellán Estab. Rio Negro (Patagonia) & $13 / 7 / 1801$ \\
\hline Miño, Santiago. & Capellán Estab.Río Negro (Patagonia) & $17 / 4 / 1786$ \\
\hline Molina, Juan Ignacio & Capellán Estab. Río Negro (Patagonia) & $25 / 8 / 1785$ \\
\hline Moreyra, Pablo & Capellán Estab. Río Negro (Patagonia & $7 / 4 / 1793$ \\
\hline Pogio, Bartolome & Cura Estab. Rio Negro (Patagonia) & $25 / 1 / 1800$ \\
\hline Posadas, Miguel & Cura Estab. Rio Negro & $26 / 5 / 1790$ \\
\hline Robledo, Pantaleón & Capellán Estab.Río Negro. & $26 / 3 / 1794$ \\
\hline Salvadores, Joaquín & Capellán Población Río Negro. & $15 / 6 / 1784$ \\
\hline Sánchez, Antonio. & Capellán Población Río Negro & $7 / 8 / 1780$ \\
\hline Tamayo, José & Capellán Fuerte Nstra. Sra. Del Carmen & $1 / 3 / 1783$ \\
\hline Teran, Tadeo & Capellán Población Río Negro & $23 / 11 / 1781$ \\
\hline Vallejos, Gaspar & Cura Fuerte del Carmen & $10 / 3 / 1790$ \\
\hline Vera, José & Capellán del Carmen & $27 / 4 / 1816$ \\
\hline
\end{tabular}

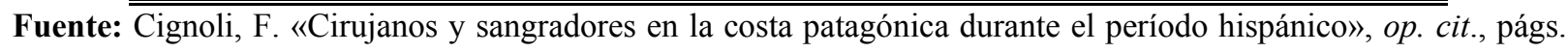
$100-101$ 


\section{Apéndice n. ${ }^{\circ} 5$}

Cuenta de los efectos comprados en Patagones por orden del Señor Coronel Don Juan Manuel Rosas con destino al establecimiento de Bahía Blanca

Por lo gastado de madera pedida $\$ 1000,00$

Por 10 rollos de tabaco superior $\$ 544,00$

Por 75 cajas yerba de mejor calidad $\$ 1125,00$

Por 2 pipas de aguardiente de España

$\$ 460,00$

Por 12 ollas de $\$ 3$ $\$ 36,00$

Por 2 pipas vino clarete abocado a $\$ 140$

$\$ 280,00$

Por 2 pipas de vino Figueras $\$ 280,00$

Por 50 cajas de Fariña $\$ 75,00$

Por 15 cajas de azúcar $5 \frac{1}{2} 2 \mathrm{p}$ $\$ 82,00$

Por 1 Barril de alquitrán $\$ 30,00$

Por lo gastado en la conducción de estos efectos $\$ 45,20$

Por almacenaje desde el $1^{\circ}$ de enero hasta fines de diciembre $\$ 30,00$ $\$ 3.987,60$

Comisión del 5\% de la comisión pagada al señor Álvarez $\$ 199.30$ $\$ 4.187 .10$

Importa la presente cuenta de cuatro mil ciento ochenta y siete pesos en real valor metálico.

Firma: Juan Manuel de Rosas

Fuente: AGN, Sala X, 14-10-6. 


\section{$\operatorname{Anexo}$ n. $^{\circ} 6$}

\section{Educadores masculinos}

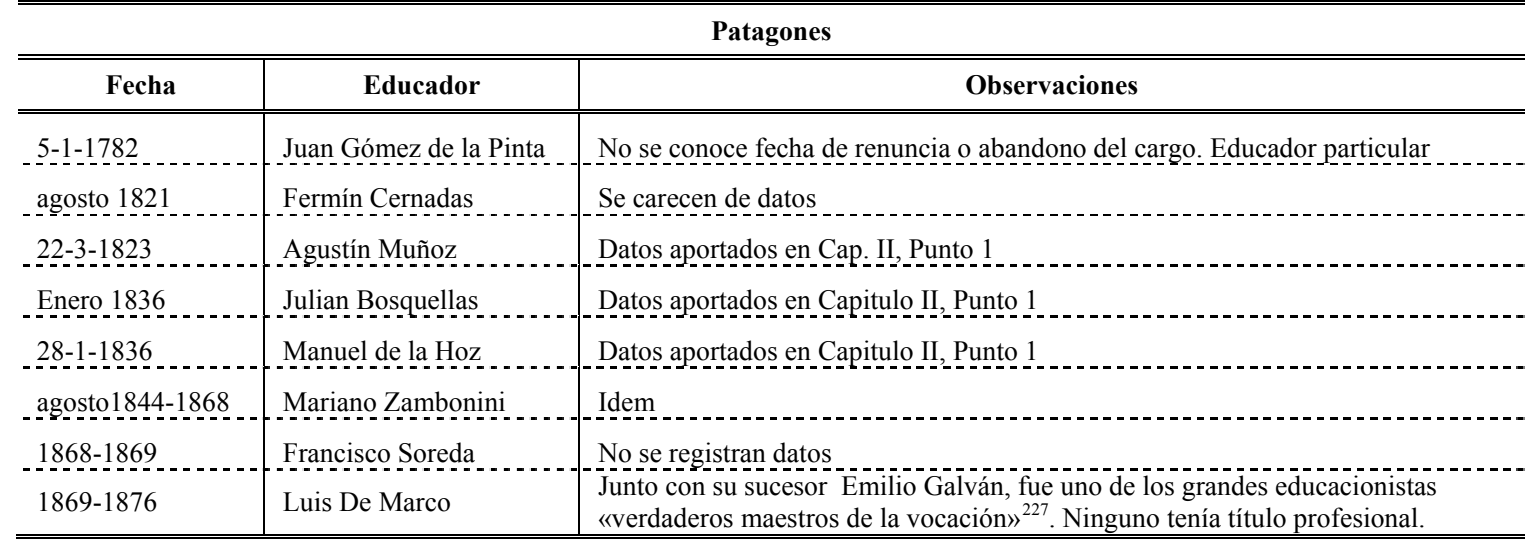

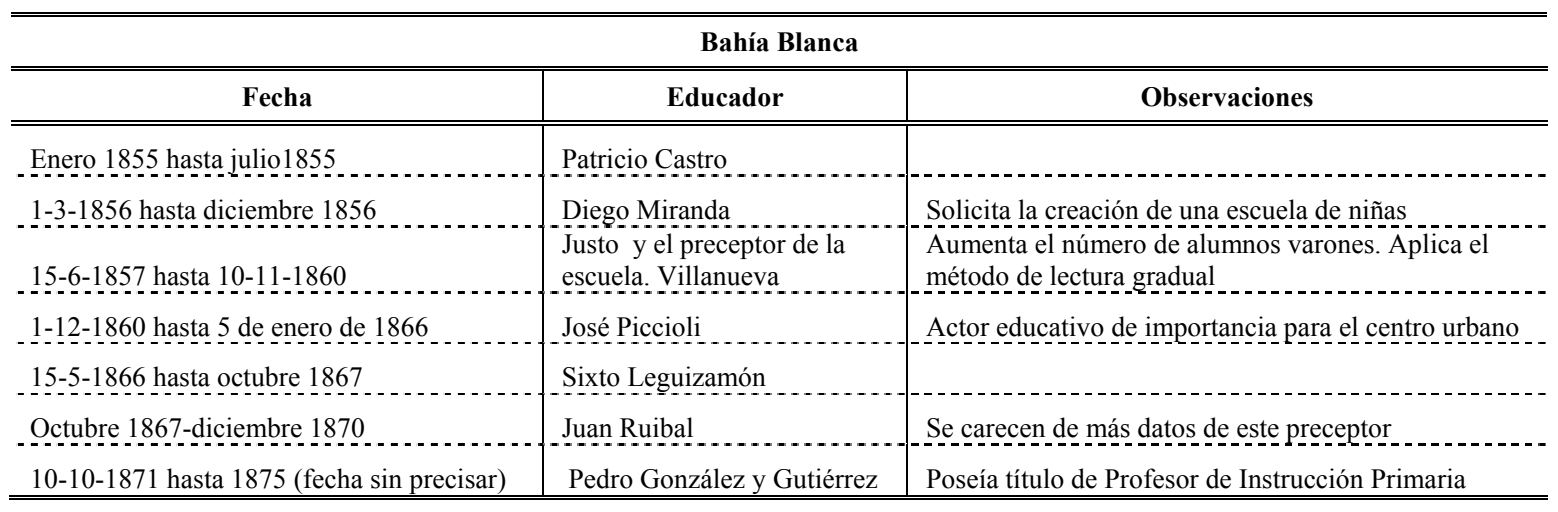

227 Pita, Francisco, ob. cit., pág. 51. 
Segunda parte

Articulación entre el modelo educativo conservador y el constitucionalismo liberal del estado bonaerense 


\section{Capítulo 3}

\section{Reformulación del sistema educativo bonaerense (1852-1871)}

\section{1.a. La búsqueda de un plan de homogeneidad educativa}

Luego de la batalla de Caseros (1852) surge un nuevo planteamiento de la política educativa, que quedaba condicionada a una nueva realidad política, social y económica.

Por una parte, la definición de un nuevo Estado que presuponía la presencia de condiciones materiales que lo integraban en un espacio económico capitalista con el fortalecimiento de una economía agroexportadora que favorecía en especial al puerto de Buenos Aires, el flujo de capitales financieros y el ingreso de grandes corrientes migratorios que proporcionaban abundante fuerza de trabajo. Nuevas inversiones en infraestructura (caminos, telégrafo y redes ferroviarias) presagiaban el fin del aislamiento que sufrían espacios de frontera como es el centro de esta tesis.

Los primeros diez años que siguieron a Caseros constituyen una etapa signada por una fuerte expansión económica que favorecía la región pampeano-litoraleña, por su cercanía a los puertos de Buenos y de Rosario.

No podemos dejar de lado la situación política en que se debatió la sociedad durante el proceso llamado de «Organización Nacional» iniciado en 1853. En este sentido, puso a la luz los sentimientos localistas que mantenían el territorio de las Provincias Unidas. El intento de Urquiza por institucionalizar y dar centralidad al sistema educativo con la creación del ministerio de Instrucción Pública, fracasan por una lucha de personalismos y de intereses tanto de la Confederación como del Estado de Buenos Aires.

El gobernador provisorio de Buenos Aires Vicente López y Planes (1852) mostró interés por la instrucción pública que por poco tiempo fue atendida por Valentín Alsina. El tesoro público asume los gastos de la enseñanza y el sostén de la universidad, interrumpidos por el decreto de Rosas de 1838 . Se constituyen comisiones para informar sobre el estado de la enseñanza primaria y del material 
pedagógico. Notoriamente, se busca dignificar a los educadores decretando la creación de la Escuela Normal, a cargo de Marcos Sastre.

Desde el punto de vista argumentativo, esbozamos los primeros pasos de la construcción de un Estado Nacional. Fue un proceso de construcción político-jurídica que buscó generar nuevos mecanismos institucionales, entre ellos la preciada homogeneidad educativa.

Las provincias se convierten en símbolos de resistencia frente a los esfuerzos de Buenos Aires para lograr su centralidad.

El surgimiento de medios periodísticos donde se vertían diferencias y alternativas de pensamiento, como los diarios El Debate dirigido por Mitre, El Nacional, por Vélez Sarsfield y La Unión de José Manuel Estrada, fueron espacios de reflexión y despliegue de ideologías, de explicación del orden político-social y la manifestación de la secularización del pensamiento. La función social más importante de este discurso es legitimar y controlar, validar opiniones e informaciones que permitan asegurar beneficios.

Las jornadas del 11 de septiembre marcaron la superioridad de Buenos Aires que fueron desarrolladas en el programa esbozado por Mitre. El caudillismo quedó encarnado en Urquiza y en los gobiernos federales del interior. Este es el momento del triunfo de las elites porteñas. Los debates parlamentarios donde descollaron Mitre, Vicente Fidel López y Vélez Sarsfield, encierran la muestra discursiva de estos intelectuales. En palabras de Altamirano, la imagen épica de los intelectuales en lucha permanente con los dueños del poder. En su línea argumentativa de una crisis de autoridad y legitimidad ${ }^{1}$. En su proyecto de creación de una nación, Buenos Aires, dirá Wasserman parecía contener los elementos que permitirían constituir una nación moderna. Era el espacio urbano más que el rural ${ }^{2}$.

\section{1.b. La Constitución del estado de Buenos Aires}

Luego del triunfo de la Revolución del 11 de septiembre, y tras un breve gobierno del general Manuel G. Pinto, la Sala de Representantes elige como Gobernador y Capitán General de la Provincia, en carácter de propietario, al doctor Pastor Obligado.

A pesar de la crisis política que reinaba en el país, Buenos Aires presentaba cierta seguridad económica, fenómeno que favorecía adelantos en la ciencia, en la industria y en la sociedad, que se expandió a toda la campaña.

Tres conceptos polisémicos en lo discursivo estructuraron las reformas que buscaba la elite dirigente: poblar, mejorar la comunicación e igualdad social. Aunque sobre el último pongamos nuestro reparo. Tal como sostiene Durkheim, un fenómeno social, sólo puede ser colectivo a condición de ser común a todos los miembros de la sociedad ${ }^{3}$. Lejos de adoptar este giro lingüístico los actores sociales que lo

\footnotetext{
${ }^{1}$ Altamirano, C. Intelectuales. Notas de investigación, op.cit., pág. 110.

${ }^{2}$ Waserman, F. op. cit., págs. 7-34.

${ }^{3}$ Durkheim, E. Las reglas del método sociológico, México, Coyoacán: [s/e], 1994, pág. 30.
} 
pronuncian se reconocen por su centralidad en las relaciones de poder y en las económicas. Su construcción cultural y jurídica iba a responder a sus conceptos de derecho y de uso de la propiedad ${ }^{4}$.

La llamada «Generación de Constituyentes» por Diego Pró, con un sentido realista y liberal, pone su atención en dar una Constitución al estado de Buenos Aires ${ }^{5}$. En sentido formal, en cuanto a su forma y efectos jurídicos, esta constitución permitiría efectivizar los conceptos articuladores nombrados, como norma escrita y en su parte dogmática.

En junio de 1852, el diputado Antonio María Pirán presentó un proyecto de ley para formar una comisión especial que elaborara el proyecto de constitución. Las jornadas del 11 de septiembre y la rebelión de Lagos interrumpieron transitoriamente el debate. El mismo, se renueva en octubre de 1853 cuando se forma una comisión constitucional compuesta por Valentín Alsina, Miguel Estévez Seguí, Nicolás Anchorena, Carlos Tejedor, Eustaquio Torres, Manuel Acosta y Manuel Escalada. Existieron disidencias en torno a temas como la «soberanía» y «ciudadanía» entre Mitre, Alsina y Tejedor.

Aprobada la constitución, realizamos un análisis hermenéutico sobre la fuente documental.

La «soberanía interior y exterior» (art. 1, sección I) estaba asociada con mantener el imperio político de Buenos Aires por sobre la Confederación, apropiándose del derecho a establecer sus propios, mientras no lo delegue en un gobierno federal, apropiándose del derecho a establecer sus propios límites. La frontera norte-sur se extendería desde el Arroyo del Medio, hasta la entrada de la cordillera en el mar, es decir, hasta Tierra del Fuego.

Reconoce que la religión del estado de Buenos Aires es católica, apostólica y romana, siendo costeada por el tesoro bonaerense. El Estado hace propia la fe católica sino que establece que sus habitantes «sea cual fueren sus opiniones religiosas» quienes deben respetarla (art. 3, sección I). Contrasentido a su declaratoria libertad de cultos, o «libertad religiosa», por cuanto como hemos visto anteriormente, la iglesia estaba presente como actor relevante en la escuela pública.

En cuanto a la sección II, sobre el concepto «ciudadanía» conserva un sentido genérico e indeterminado. La voz de ciudadano reemplaza la de vecino, incluía a todos los hombres libres pero con derechos políticos limitados. La ciudadanía tuvo que ser sostenida por la vecindad a partir de 1852 , porque en la práctica cotidiana vecinos y ciudadanos estaban vinculados a las autoridades provinciales. La construcción de la ciudadanía fue una empresa imposible en la Confederación, Buenos Aires podía asignar «ciudadanía» dada su autonomía ${ }^{6}$.

En la sección IV, artículo 28, establece la elección y composición del senado, que serían elegidos directamente por el pueblo. Establecía la correspondencia de un senador cada 12 mil habitantes. Por «la sección Campaña» se elegía uno por cada sección, exceptuando Bahía Blanca y Carmen de Patagones, quienes podrían enviar un solo representante. Esta norma jurídica predetermina en forma concreta límites técnicos en cuanto a número de habitantes. Para estas formas de representatividad Martínez

\footnotetext{
${ }^{4}$ Cfr. Thompson, E. P. Agenda para una historia radical, Barcelona: Crítica, 2000, págs. 39-40.

${ }^{5}$ Pró, D. Anuario de Historia del Pensamiento Argentino, Tomo I, Instituto de Filosofía, Universidad de Cuyo, Mendoza, 1965, págs. 24-26.

Constitución del Estado de Buenos Aires sancionada por la Honorable A. Constituyente el once de abril de 1854, Buenos Aires: Imprenta Americana, 1870.

${ }^{6}$ Cansanello, O. C. op. cit., págs. 19-32.
} 
Estrada dirá: «La desproporcionada grandeza es la desproporcionada pequeñez de lo otro» ${ }^{7}$. La campaña fue la pequeñez. La composición del senado quedaría reservada para militares y una elite de civiles con gravitación política y económica.

La Sección VIII, en sus Declaraciones Generales, declara «que todos sus habitantes tienen un derecho a ser protejidos (sic) en el goce de su vida, reputación, libertad, seguridad y propiedad» La nueva constitución instala en su articulado la continuidad en el derecho a la vida y a la seguridad individual y propiedad, aunque las prácticas en la campaña mostraban a esta declamación como una quimera. Ni la acción de la justicia de paz y de comandantes de campaña analizadas con anterioridad refleja o traducen el cumplimiento de lo proclamado (art. 145).

El art. 169 instituye que la educación «al menos la primaria» sea costeada por el tesoro del Estado y la transforma en instrumento de cambio social. Esta tendencia busca despojar las atribuciones educativas de los privados, la Iglesia, y lograr un control general de la política educativa. Primer paso a la proclamación de la obligatoriedad y gratuidad educativa.

El 11 de abril de 1854 es aprobada esta constitución con la firma de todos los miembros de la Asamblea y de sus secretarios, Manuel Pérez del Cerro y Adolfo Alsina.

\section{1.c. Cambios estructurales de la educación bonaerense (1853-1871)}

Valentín Alsina como gobernador (1852; 1857-1859) de la provincia de Buenos Aires definió los grandes cambios de una época a pesar de transitar por luchas internas y complejas divisiones políticas. Contó con un grupo de intelectuales en su gabinete con una orientación hacia el futuro donde cohabitan el discurso ideológico liberal y un realismo político dado por el contexto territorial en el que lo debe aplicar. En su segundo gobierno contó con el apoyo en el ministerio de Gobierno a José Barros Pazos, jurisconsulto cordobés y diputado de la primera Asamblea Legislativa de 1852 que sucesivamente desempeñó el cargo de Director General de Escuelas y Rector de la Universidad. Para fomentar el desarrollo de la población y el trabajo en el campo entrega buena extensión de tierras públicas ${ }^{8}$. La línea de frontera se extendería por propuesta de Saturnino Salas del Departamento Topográfico hasta Fortín Mercedes. Fenómeno técnico de construcción del Estado que significo un cambio del saber territorial ${ }^{9}$.

La campaña fue dividida en departamentos, cuarteles y secciones. En cuanto a su política educativa, estableció que la enseñanza primaria sea obligatoria y por el decreto de julio de 1866 dispuso que los nombramientos de profesores y maestros quedaran a cargo del Consejo de Instrucción Pública. Para Puiggros, esto demuestra cómo el vínculo pedagógico era de instrucción pública, siendo el educador portador de una cultura superior frente a un sujeto negado o socialmente inepto ${ }^{10}$.

\footnotetext{
${ }^{7}$ Martínez Estrada, E. Radiografía de la Pampa, Buenos Aires: Losada, 1942, pág. 149.

${ }^{8}$ Valencia, M. Tierras públicas, tierras privadas. Buenos Aires 1852-1856, La Plata, UNLP, págs. 43-48.

${ }^{9}$ Cfr. Gautreau, P. y Garavaglia, J. C. op. cit., págs. 73-150.

${ }^{10}$ Puiggros, A. op. cit., pág. 41.
} 
Hacemos una pequeña digresión, en cuanto a esta afirmación. Al disentir parcialmente en tanto existe una relación entre políticos como Alsina con una concepción realista de su política, de funcionarios y profesionales liberales cuya dinámica de vida y obras se arraiga en un contexto y en una época particular $^{11}$. Desde el punto de vista ideológico la instrucción legitima el orden establecido y a su vez considera a la cultura como instrumento de distinción. Desde el punto de vista filosófico, la instrucción trasmite habilidades y destrezas. Es un proceso formalizado que se comunica en un primer nivel de conocimientos (leer, escribir, hablar, etc.) y en un segundo nivel, conocimientos específicos. La educación es un proceso social de mayor complejidad que la instrucción.

Continuando con la labor de Alsina a nivel educativo, fortalece los estudios de Historia Natural, de Ciencias Exactas y de Físico-Química en la universidad, con la creación de gabinetes, laboratorios y la contratación de científicos extranjeros.

Según Barba, pese al conflicto que mantenía Buenos Aires con la Confederación, el número de escuelas fue en aumento. Y el territorio bonaerense marchaba al frente de la educación popular, no solo en nuestro país sino en América Latina. Otro aspecto que destaca este autor es que el número de escuelas para niñas era mayor que el destinado para los varones ${ }^{12}$.

La renovación del Poder Ejecutivo Nacional genera un nuevo clima de debate en los medios periodísticos, dando lugar a la aparición del diario La Patria, cuyos redactores eran Aristóbulo del Valle, Manuel Alberdi y Eduardo J. Wilde. Estos nombres, junto al posterior gobernador Emilio Castro, nos facilita una comprensión histórica sobre prácticas culturales que buscaron la innovación educativa. En ellos estaba presente que la educación era representación de un progreso universal y sin límites, asociada con la idea de perfección que pondría paulatinamente fin a la llamada «barbarie» de la campaña.

En septiembre de 1857 se produce la ruptura de Buenos Aires con la Confederación a pesar de los intentos de esta última por atraer al estado de Buenos Aires. Estas tentativas de conciliación no estuvieron exentas de tensiones internas y contradicciones por la toma de conciencia de Buenos Aires de su superioridad económica al tener en sus manos el mejor instrumento: el puerto.

Cepeda concluye con la renuncia de Alsina como gobernador frente a una situación dramática en Buenos Aires ante los rigores del sitio.

Actores políticos, de producción, de pensamiento o pertenecientes a movimientos cívicos como Valentín Alsina, Bartolomé Mitre, Vélez Sarsfield, Sarmiento, José Mármol, José Barros Pazos, entre otros, integrarán la comisión de la Convención Provincial de Buenos Aires que conduciría posteriormente a la jura de la Constitución Nacional. Constituyeron un conjunto amplio de intelectuales y operadores del mensaje ideológico de la Generación del 37, quienes entran a conducir el país iniciando otra generación que prepara sus armas culturales ${ }^{13}$. La personalidad y experiencia de estos hombres

11 La dinámica de la instrucción en el proceso educativo.sisbib.unmsm.edu.pe/bibvirtual/publicaciones/ inv.educativa/2009_23/pdf/a10v13n23

${ }^{12}$ Barba, F. «La ley de Educación Común de Buenos Aires de 1875», Trabajo y Comunicaciones, n. ${ }^{\circ}$ 18, Departamento de Historia, Facultad de Humanidades y Ciencias de la Educación, La Plata, Universidad Nacional de La Plata, 1968, págs. 53-65.

${ }^{13}$ Pró, D. F. op. cit., págs. 24-26. 
hacen que se impongan sus criterios, valoraciones, organicen jurídicamente el país, y orienten la acción política, económica y social.

El 2 de mayo de 1860 Bartolomé Mitre será designado gobernador de la provincia. Dos años después, en el mes de octubre de 1862, asume como presidente de la Nación, quedando el gobierno de la provincia a cargo de Mariano Saavedra.

Saavedra continua con la política de extensión de líneas férreas y el arrendamiento de tierras públicas, que en el caso de Bahía Blanca y Patagones el porcentaje de entrega es menor por parte de los sectores hegemónicos de producción capitalista dado al escaso interés que presentaba la región por sobre las zonas al norte de las otras secciones en cuanto a mayor productividad agraria. Ambas localidades integraban la tercera sección, y en su venta, solo llegaron a un $17 \%$ por sobre el resto del territorio bonaerense ${ }^{14}$.

Las escuelas se multiplicaron en la campaña y este aspecto determinó la creación del Consejo de Instrucción Pública (5 de octubre de 1864) que dirigiría escuela primaria. A nivel universitario se crea del Departamento de Ciencias Exactas, quedando su enseñanza a cargo de profesores europeos. La prioridad que comienzan a tener las ciencias exactas plantea nuevos planteamientos epistemológicos sobre la naturaleza del descubrimiento científico: al jerarquizar las prácticas científicas en la universidad actuaría como política de derrame hacia la educación primaria y secundaria ${ }^{15}$.

En julio de 1869, mientras se dictase la Ley General de Educación, se designó jefe del departamento general de escuelas a José Manuel Estrada. Entre las figuras que integraban el Consejo de Instrucción Pública encontramos a Luis J. de la Peña, Juana Manso, Luis Sáenz Peña, Pedro Goyena, Eduardo Costa y José Barros Pazos entre otros.

Posteriormente, el tema de la educación se tratará en la Convención Constituyente de la provincia entre 1870-1873. La riqueza de los debates analizados por Barba, permiten conocer las distintas posiciones y diferencias en una nueva operación de interpretación sobre conceptos como «educación primaria»y «educación común».

A nivel teórico e ideológico, esta generación de los constituyentes, como sector social dominante, se planteó la disminución del analfabetismo y la defensa del conocimiento. A pesar, que en el futuro se confirme el postulado de Althuser: «...el conocimiento está dotado de un efecto subversivo respecto del discurso ideológico. ¿Qué subvierte? Las evidencias ideológicas» ${ }^{16}$.

Este planteo nos permite vincular cómo desde esa práctica teórica (que es leer, escribir, pensar) podían surgir en un futuro próximo, oposiciones propias a las teorías. La prevalencia de este fenómeno, se dio fundamentalmente después de la Ley n. ${ }^{\circ} 1420$ por parte de los hijos de inmigrantes. El desarrollo económico, la inmigración y la educación eran instrumentos para alcanzar un cambio. Se puso en movimiento una nueva estructura de desarrollo, que lentamente fue modificando la posición política de la dirigencia tradicional. La educación abre nuevos espacios político-sociales a sectores medios más

\footnotetext{
${ }^{14}$ Valencia, M. op. cit., págs. 147-148.

${ }^{15}$ Cfr. Bordieu, P.; Chamboredon J.-C. y Passeron, J.-C. op. cit., págs. 82-83.

${ }^{16}$ Karsz, S. y otros. Lectura de Althusser, Buenos Aires: Galerna, 1970, págs. 22.
} 
consolidados. La educación fue el medio de transformación, acompañando cambios económicos y nuevas prácticas laborales.

Estos hombres apuestan al «orden» y «progreso». Se puede distinguir en estas formulaciones lo que Barthes denomina «código». El «código» es el surco donde se constituye un paradigma de país. De la concurrencia de estos dos códigos devienen los códigos culturales. En este tejido voces, aparece un enunciado como en tiempo de Rosas: el orden ${ }^{17}$.

El orden es la abstracción que permite recordar que sin él, habrá conflictos civiles y militares y que serán la oposición a la creación de un sistema político y legal. Instaurar «el orden» significaba dar vida a un Estado Nacional. La ausencia de «orden» impedía la concreción del «progreso».

El «progreso» da cierta coherencia a fenómenos que forman el devenir humano.

En la práctica se logra con la organización de las Guardias Nacionales y las milicias que daban seguridad al necesario poblamiento de la campaña. Favorecían el establecimiento de familias y la evitación del estado de inseguridad e incomunicación que había acompañado a los actores educativos. Bahía Blanca y Carmen de Patagones se verán favorecidas con un nuevo régimen de la tierra pública, aunque tardíamente por la latente inseguridad de malones indígenas. En Bahía Blanca, el último de ellos se produjo en 1869.

A pesar de ellos, el desarrollo de las vías de comunicación a través de la extensión de vías férreas, mejora de caminos terrestres, rompía paulatinamente con años de aislamiento institucional del sudoeste bonaerense.

El disciplinamiento de la fuerza de trabajo iba a estar acompañado por supuesto plan de homogeneidad educativa que no solo se limitaba a Buenos Aires sino a la campaña. Pero la homogeneidad podría caer en un fracaso ante la diversidad cultural que presentaba el territorio bonaerense. La diversidad de lenguajes políticos, de prácticas educativas significantes, estilos y opiniones, no lograría la llamada hegemonía de Gramsci, pero permitiría desde lo ideológico sistemas de dominación política y económica, según sus destinatarios y el espacio que ocupaban.

La organización nacional tenía un significante: la vigencia de los postulados liberales. El conjunto de actores sociales e instituciones que se conoce como «sistema educativo» representa —entre otras - una dimensión decisiva de los estados modernos. Es para Oslak una herramienta centralizada de homogeneidad cultural dentro de un territorio específico. La educación constituyó un vehículo privilegiado en el marco de la estratégica penetración del Estado ${ }^{18}$.

La educación tuvo una función política, completaron un proceso socializador e integrales de nuevas generaciones. La escuela primaria cumplió un papel integrador por la transmisión de valores seculares y pautas universalistas. La educación sería instrumento que aseguraba la gobernabilidad, garantía de orden y preparaba a sujetos aptos para una nueva burocracia estatal.

\footnotetext{
${ }^{17}$ Barthes, R. S/Z, Buenos Aires: Siglo XXI, 2009, págs. 27-29.

${ }^{18}$ Oslak, O. op. cit., págs. 150-153.
} 


\section{1.d. Concreción de las ideas de la Generación del 37}

En este contexto parecía cumplirse los viejos postulados de la Generación del 37: Mayo, Progreso y Democracia. Mayo era axioma de igualdad y libertad. La igualdad era condición para superar la libertad de pensamiento. La religión debía ser independiente a la sociedad civil y por lo tanto, la educación debía estar ajena a toda condición de credo. Las Bases... de Alberdi que fueron fundamento de la Constitución Nacional sancionada en mayo de 1853 encierran la teoría de una transición que debía permitir que germinen en el pueblo las costumbres para una vida republicana de la que carecía entonces. Tal como lo sostiene Altamirano, el país debía «practicar la república» y los agentes de cambio eran la inmigración europea, los ferrocarriles, la industria y la formación cívica de la población ${ }^{19}$.

Según Félix Weinberg, Alberdi habría insistido para eliminar entre nosotros la enseñanza abstracta y esterilizante, remplazándola por estudios prácticos. Apunta a diferencia de su contemporáneo Sarmiento, dirigir la atención a España y contribuir a una necesaria introspección de lo americano, atenuando el eurocentrismo ${ }^{20}$.

Puiggrós, a contracara de Weinberg, considera que al igual que Sarmiento, borró al sujeto social real y vuelve a una propuesta educativa abstracta.

Compartiendo la teoría de Szuchman, Carlos Newland entiende que Alberdi entiende que la educación primaria dada al pueblo había sido perniciosa por cuanto el aprender a leer había significado la manipulación políticamente. La inmigración cumpliría una función de ósmosis al contagiar a la población de hábitos de orden, disciplina e industria ${ }^{21}$.

La propuesta del pensamiento de Sarmiento define en el campo discursivo lo que Puiggrós llama «normalizadores laicos» con influencias ideológicas de Guizot, Horace Mann y Henry Barnard. Entiende que la educación popular pregonada por Sarmiento no se dirigía a los sujetos sociales populares porque entendía a la población como una masa de insurrectos e irregulares.

Su sostén era la educación laica y estatal como una forma de control de las particularidades que presentaban las diferentes oleadas inmigratorias.

Entiendo a Sarmiento como sujeto transformador de una época y es indudable que su pensamiento educativo dominó toda la segunda mitad del siglo XIX, pero particularmente en el Estado y luego provincia de Buenos Aires. Requiere su filosofía de la historia y su postulado de una evolución progresiva de los pueblos en aislamiento, para lograr una comprensión de contexto histórico en que desarrolla su praxis.

\footnotetext{
${ }^{19}$ Altamirano, C. «Ideas y costumbres», Boletín del Instituto de Historia Argentina y americana Doctor Emilio Ravignani, Tercera serie, n. $^{\circ} 33$, págs. 210-211.

${ }^{20}$ Weinberg, F. «Alberdi en 1843. Viaje a Europa y giro ideológico», América Latina. Historia y Destino. Homenaje a Leopoldo Zea, México, UNAM, 1992, págs. 429-442.

${ }^{21}$ Szuchman, M. Order, family and community in Buenos Aires (1810-1860), Estados Unidos, Sttanford, 1980, págs. 8-9; Newland, C. op. cit., pág. 43.
} 


\section{El Plan Combinado de Educación Común de Sarmiento y su aplicabilidad a la realidad socio económica del Estado de Buenos Aires.}

En este punto analizaremos discursivamente la segunda edición del Plan Combinado de Educación en el estado de Buenos Aires, obra de Domingo Faustino Sarmiento. Uno de los autores argentinos del siglo XIX que marcaron la internacionalización de nuestra literatura y del pensamiento propiamente sudamericano. Confundido entre dos generaciones, la del socialismo romántico de los hombres del 37 y el pensamiento generacional que se inscribe a partir de 1853, permite anticipar una formación ideológica fragmentaria y parcial. Estudiado por numerosos autores, literatos, historiadores, sociólogos y filósofos, su obra de más de treinta tomos ha sido analizada y desmenuzada hasta la actualidad.

Cabe preguntarse por qué me detengo en esta obra de este supuestamente agotados en miles de obras que sobre él se publicaron. Consideré necesario su estudio por cuanto entiendo que es un plan educativo futuro, el diagnóstico más acabado de la sociedad, la geografía de una región determinada en la cual se pondría en marcha.

La primera edición de este Plan es anterior a su designación como jefe del Departamento de Escuelas del estado de Buenos Aires. Se publicó en Chile en 1855 en la imprenta de su yerno Julio Belin bajo el nombre de Plan Combinado de educación común, silvicultura e industria pastoril. Esta obra es una formulación educativa para una región específica del país, demarcada y delineada geográfica y económicamente.

Tomando el concepto de «región» utilizado por Eric Van Young, «regionaliza un espacio» donde pretende una diferenciación económica intraregional (noreste del territorio bonaerense frente al noroeste $\mathrm{y}$ sud del mismo ${ }^{22}$. Hablamos de un espacio geográfico con una frontera móvil que lo activa y determina el alcance del sistema político y económico del momento.

En la indagación e interpretación hermenéutica se observan cambios en los ciclos educativos que se producen en la provincia entre 1852 a 1870 . La acción de Sarmiento fue vital tanto como jefe del departamento de escuelas del estado de Buenos Aires y posteriormente como director de escuelas de la provincia.

Sarmiento precede esta obra con una frase de Rendu que trasluce su convicción sobre el determinismo ético, político y social que le confiere a la educación:

\footnotetext{
Las cuestiones de moralidad como las cuestiones de trabajo, las cuestiones de criminalidad como las cuestiones de ejercicio de los derechos políticos, todos estos problemas, cuya solución conmueve las profundidades del orden social, todos parten de la instrucción primaria y todos vuelven a ella ${ }^{23}$.
}

\footnotetext{
${ }^{22}$ Van Young, E. «Haciendo historia regional. Consideraciones metodológicas y teóricas», Anuario IEHS, Tandil, 1987, págs. 255-281.

${ }^{23}$ Sarmiento, D. F. Educación Común en el Estado de Buenos Aires, Buenos Aires: El Censor, 1887, pág. 2.
} 
El plan combinado era la contrapuesta a un país concebido como una estancia. Era la sustitución del gaucho u hombre a caballo por el «vecino desmontado».

La posibilidad de concretar un proyecto educativo para el país partió de la realidad que le presentaba Buenos Aires y su campaña.

Está convencido que la «barbarie» en territorio pampeano se debió a una mala política de parcialización de la tierra y su derivación en latifundios. Le preocupa la falta de elementos naturales, como bosques y maderas, que permitieran cercar y separar el ganado: «....antes que haya niños por todos partes en el territorio, se necesita leña para quemar ladrillo, madera i palos para construcciones, plantas para cercas... antes que existan las escuelas ha de haber madera para techarlas» ${ }^{24}$.

En lo referente a los órganos de beneficencia, parte del concepto sostenido por legislaciones contemporáneas, de convertir a los centros de asistencia social en espacios donde se eduquen a los niños.

Abundan en esta obra los ejemplos de Estados Unidos y los europeos, excluyendo a España por su paternidad en nuestra «funesta legislación». Esta obra apunta al porvenir y por ello es trascendente. La utopía sarmientina en su producción literaria genera diversas lecturas: la mirada a un futuro que sea la contracara al régimen establecido por Rosas. Y por otro lado, el compromiso personal que lo involucra no solo a él sino al lector a fin de participar en un nuevo orden de cosas. La utopía encierra aquí la construcción de un mundo alternativo, en el cual se concretarían distintos ideales: a) la educación común, «...paladium de la libertad, de la civilización, de la moral y del desarrollo...».

b) Gratuidad: «La escuela debe estar al alcance de todos sin relación a la fortuna de cada uno». El Estado controlará el desarrollo efectivo de todo proceso educativo.

c) Obligatoriedad: Basándose en la legislación de Massachusetts, de Baviera, Austria y Prusia, se puede ejercer el carácter coercitivo sobre los padres o tutores que no cumplan con su deber de educar a sus hijos.

Entiende que el territorio bonaerense ha estado hasta ahora dominado por «asociaciones familiares» cuyos vínculos de unidad les confería una estructura similar a los patrones de estancia, con una producción netamente primaria. La tenencia de la tierra o del poder político posibilitaba que solo esas familias tuvieran cercanía a los centros educativos.

En abril de 1854 desde Yungay le había escrito a Mitre anticipando su viaje a Estados Unidos enviado por la Universidad de Chile para estudiar temas de educación. Estas ideas, fruto de veinte años de estudios sobre el tema, quedarían plasmadas en este plan, para ser en el futuro aplicadas en Buenos Aires.

En esta misma carta confiesa cuánto costará convencer a la legislatura, suponiendo que existe una mentalidad retrógrada en quienes legislan heredadas de una tradición hispana. También, le confiesa que este plan educativo basado en datos aportados por la traducción de Justo Maeso de la obra de Woodbine Parish, será casi como «un traje a medida» para el territorio bonaerense.

El Plan Combinado — tal como él mismo lo sostiene - fue «una feliz anticipación histórica» al ser publicado en 1855.

\footnotetext{
${ }^{24}$ Sarmiento, D. F. op. cit., pág. 26.
} 
Perfila distintas imágenes que se dan al visualizar la provincia. Discrimina el espacio urbano, con Buenos Aires como ciudad moderna, de la campaña a la que aplica el vocablo «pampa», que en sentido genérico equivale a estepa o sabana. La caracteriza a esta última por la falta de ríos y de bosques, que impiden el mantenimiento de la humedad de su tierra.

A partir de 1852 la sociedad argentina está frente a una nueva organización institucional, en la cual el Estado constituyo un orden reciente en el que se concreta la capacidad de acción del colectivo. Se plantea un nuevo sistema de diferenciación social donde es el Estado y no el sistema de parentesco el que determine la estructura de la sociedad. La estratificación queda ligada fundamentalmente a atributos como el poder político y el prestigio. El prestigio se puede lograr a través del control económico o del saber.

Sarmiento vislumbra a la educación como facilitador del cambio social y curiosamente, en esta obra, los espacios giran en torno al sujeto y determinan una política educativa, justificada en pos de su ámbito geográfico.

Las vías de comunicación - en esta etapa pre-ferroviaria - es una de las desventajas que sufre el territorio bonaerense. Pero la educación de los hombres que habitan este territorio, «...no ha de encaminarse a la industria fabril...sino de aprovechar las ventajas que resultan de sus propios defectos $\cdot »^{25}$.

La propuesta de Sarmiento abarcaría al espacio que ocupara la escuela en cada población que se creara en la extensión de la línea de frontera. En este plan le confiere un papel activo al maestro no como simple pedagogo sino como pequeños productores que no solo enseñan a leer y escribir sino a cultivar la tierra.

La extensión de la educación común aumenta entre 1856 hasta 1861, de 177 a 361 escuelas. Por la ley de edificación escolar se destinan fondos especiales para la erección de escuelas con el beneficio de la región sudoeste y sudeste bonaerense. El fomento de los ferrocarriles estuvo asociado a la legislación sobre tierras públicas ya analizada. La creación de la Escuela Normal de preceptores en 1865, cumple parcialmente los objetivos de Sarmiento.

Curiosamente el árbol y el libro adquieren en esta obra un protagonismo inusitado. Parcialmente, la utopía sarmientina se concreta abigarrada en una primigenia organización estatal y amparada, en un primer momento, en la secesión bonaerense. Consideramos, por tanto, que existen suficientes razones para rescatar del olvido este Plan Combinado, que se convierte en la antesala de los proyectos educativos desarrollados posteriormente.

La revisión de la historia educativa de la provincia de Buenos Aires, nos lleva a comprobar cómo desde el momento de la redacción de este Plan y hasta su muerte en 1888, los planteamientos teóricos se plasmaron en una realidad.

\footnotetext{
${ }^{25}$ Idem, pág. 60.
} 


\section{La frontera sudoeste: progreso y educación en la mirada de Sarmiento}

El espacio del sudoeste bonaerense, al ser designado Jefe del Departamento de Escuelas, no estuvo ajeno a esa utopía de Sarmiento, al ser designado Jefe del Departamento de Escuelas.

Concibió a la colonización como la garantía de avance fronterizo. La llegada de la Legión Agrícola convertía a la ciudad en punto de avanzada al desierto, en un «freno insolente de la audacia de los bárbaros» ${ }^{26}$. La presencia de la Legión garantiza el sudoeste del territorio impidiendo el avance de Calfulcurá.

«Roma debe existir y existirá», afirma, al imaginar que será Bahía Blanca la Roma en América del Sur. La llama «La Nueva Roma del Sur». El nombre no es caprichoso. Roma era la palabra de reunión de todas las fracciones de aquel pueblo. Esa sería la lección útil para nosotros. Con su fundación se inauguraría una nueva forma de ocupación de la tierra por cuanto el avance se realizaría con poblaciones y hombres que por ser «seres civilizados» detendrían el paso del indígena.

En el diario El Nacional del 26 de enero de 1856, repite la voz de Dante: «Se tu segui tu stella, non puoi falliere a glorioso porto». Este lema será el de los colonos italianos, quienes lo han pública en un diario. El modelo de colonización que toma es el mismo que llevan a cabo los norteamericanos: trazan una población, levantan un templo, una escuela y una imprenta. La colonia agrícola trajo su imprenta, El puerto favorece su progreso y hombres como Olivieri, Susini y Fourmantin constituyen un grupo de soldados europeos de honor.

Bahía Blanca y Patagones, situados en la parte menos poblada del estado de Buenos Aires, tienen la ventaja de estar situadas a la vera de dos ríos: El río Sauce Grande y el río Negro.

$\mathrm{Y}$ en este proyecto que difunde en distintos números de El Nacional concluye en lo que fue el posterior informe de ingeniero Carlos Pellegrini: «Una colonia feliz será el primer eslabón de una cadena de pueblos escalonándose de Bahía Blanca a Choele Choel, y acaso hasta los Andes...La Roma de feliz augurio, puede ser, un día no muy remoto, capital del Estado de Bahía Blanca...» ${ }^{27}$.

Podríamos concluir que dentro de la formación discursiva de Sarmiento pueden detectarse la búsqueda de un cambio transformador de un espacio desconocido y tan incierto en sus fronteras. Hace surgir con obstinación de la abstracción de sus ideales o sistemas observados en sus viajes, la concreción nueva formas de colonización, una fundación originaria y la apertura de un nuevo horizonte de desarrollo político cultural.

\section{El texto escolar como primera aproximación a la lectura en escuelas de frontera}

Dentro de los desafíos de las nuevas autoridades, el problema de la enseñanza de la lengua castellana permitía el fortalecimiento de la idea de nación y la búsqueda de una homogeneidad cultural. Desde la mirada de Gramsci podemos entenderlo como formas de control y hegemonía ideológica, impregnando

\footnotetext{
${ }^{26}$ Sarmiento, D. F. Obras, Tomo XXIII, Buenos Aires: La Facultad, 1913, pág. 356.

${ }^{27}$ Idem., pág. 338.
} 
las prácticas y rutinas de una cultura dominante. La historia de la lectura ha demostrado cómo los lectores en plena actividad, amoldan sus mentes a los textos, siendo estos mismos los que realizan su propia interpretación ${ }^{28}$. Entendiendo a la lectura como un fenómeno político y social, podremos concebir la dinámica entre la modalidad y el contexto histórico, cultural e ideológico.

Al estudiar qué leían los niños de las escuelas de frontera nos permite sacar a la luz una gran cantidad de información sobre «quien». «qué», «dónde» y «cuándo» leía este alumno. La lectura es un instrumento que facilitará 1 fortalecimiento del concepto de nación y la búsqueda de despojar a la iglesia de privilegios corporativos en la educación ${ }^{29}$.

¿Quiénes leían? El padre o madre alfabetizada, les proveían los primeros instrumentos y los acercaban a la lectura en sus hogares. Los padres habían pertenecido a las milicias o cuerpos militares o elites de blancos, tal como lo hemos analizado previamente. ¿Qué leían? Predominaban los «catecismos» vinculados a la catequización y las cartillas o silabarios, con varias series de combinaciones de vocales precedidas por consonantes, de autores españoles. A partir de la Revolución de Mayo este fenómeno se extiende a las escuelas de la Patria, trabajando fundamentalmente con la memorización, siendo la obra más conocida El Catón.

A partir de 1849, la edición de la obra de Sarmiento Método de lectura gradual y posteriormente Marcos Sastre con sus Consejos de oro sobre la Educación dirigidos a las madres de familia y á los institutores, introducen cierta modernización en las lecturas acompañadas de ilustraciones familiares o el Catecismo de la Doctrina cristiana para uso de las escuelas. En un análisis realizado en la Biblioteca del Maestro, hemos podido consultar cuales eran las obras seleccionadas para las escuelas en esta etapa, encontrando algunos ejemplares como las del abate Fleury Catecismo histórico; Santiago Estrada Catecismo de Historia Argentina; Gaspar Astete, Catecismo de la Doctrina Cristiana y D. E. Sachi, Catecismo del agrónomo ${ }^{30}$.

¿DÓnde leían? El único espacio donde podrían leer un niño en la frontera, era en su hogar o en edificios poco aptos para las escuelas del estado ${ }^{31}$.

En 1858, el preceptor de Bahía Blanca, Justo Villanueva, solicita a Sarmiento el Método gradual y veinticuatro ejemplares de Anagnosias, libros que no llegaron por el naufragio del bergantín «Medora». Un año antes, Zambonini le escribe a Sarmiento acusando recibo de los «libros primarios», que ha recibido con cierto atraso. La distancia y los medios en que los libros y el material didáctico eran transportados a ambas localidades era un factor que diferenciaba la realidad escolar del sudoeste con el resto del territorio. Este educador le informa al Jefe del Departamento de Escuelas, que será el vecino Manuel B. Álvarez el encargado de transportar materiales didácticos como la «...gramática castellana

\footnotetext{
${ }^{29}$ Darton, R. «Historia de la lectura», en: Burke, P. (ed) Formas de hacer historia, Madrid: Alianza Universidad, $[\mathrm{s} / \mathrm{f}]$.

${ }^{30}$ Obras consultadas en la Biblioteca Nacional del Maestro.

${ }^{31}$ Guenaga de Silva, R. «Piedra Buena Luis. Vanguardia Argentina en la Región austral», Boletín Histórico, n. ${ }^{\circ}$ 12, Comisión de Reafirmación Histórica, Bahía Blanca, 1983, págs. 8-10.
} 
por Quiroz, tablas de contar, aritmética y libros primarios para que los alumnos puedan por ellos perfeccionar otros ramos...» ${ }^{32}$.

Según la nación positivista la alfabetización capacitaría a los alumnos en el dominio de técnicas que permitieran la interpretación de la lengua castellana. En consonancia con ello, en los Anales de Educación Común de 1860 la campaña es mirada como zonas de oscurantismo donde el analfabetismo podía generar fenómenos como en Francia e Italia donde en ámbitos campesinos se mantenían los dialectos que transformaba a esa aldea en una nación ante la variedad de idiomas ${ }^{33}$. La unificación idiomática, en este caso el castellano, facilitaría la ruptura de la diversidad lingüística de criollos, indígenas, negros e inmigrantes europeos.

Este apartado se ha centrado específicamente en los textos escolares que utilizaban los educadores en este espacio de frontera. No pretendemos reseñar los diferentes aportes historiográficos y contribuciones al estudio del texto escolar sino la singularidad que estos tienen para educadores de Bahía Blanca y Patagones. Existen trabajos representativos que provienen del campo de la Ciencias de la Educación ${ }^{34}$. En nuestro caso, buscamos delinear cómo el texto escolar contribuía a introducir en los centros urbanos referidos discursos político-sociales para una sociedad aislada y que iban acompañados de símbolos, eslogan y justificaciones sobre conceptos que resultaban ajenos para estos pueblos: como nación, patria o estado y la introducción del término ciudadanía que hemos visto con la Constitución del estado de Buenos Aires ${ }^{35}$.

Existió una ecuación nación versus estado, que se identificada con el discurso político a mediados del siglo XIX. Pero a esta ecuación se agrega el «pueblo», hacia principios del siglo XIX, vinculado con el espacio territorial donde se estructuran y definen.

Historiadores europeos pusieron énfasis en estos estudios sobre el concepto de nación, entendiendo que conceptualmente que es una comunidad política «imaginada» donde sus miembros no se conocen entre sí pero tienen lazos en común ${ }^{36}$. Comunidades de intereses compartidos, de construcción diaria

\footnotetext{
${ }^{32}$ AHPBARL, Dirección General de Escuelas, Carpeta 2507, 15-6-57.

${ }^{33}$ Anales de Educación Común, Volumen II, 1 de abril de 1860, Buenos Aires, n. ${ }^{\circ}$ 16, págs. 482-483.

${ }^{34}$ Podemos citar algunos autores en este punto aunque consideramos de relevancia los de Alzate Piedrahita, M. V.; Gómez Mendoza, M. A. y Romero Loaiza Textos escolares y representaciones sociales de la familia, Colombia, Universidad Tecnológica de Pereiram 1998; De Amézola, G y Barletta, A. M. «Un historiador piensa en la escuela. Los manuales de José Luis Romero en su obra y proyecto histórico», Clío y Asociados, n. ${ }^{\circ}$, Universidad Nacional del Litoral; Bravslavsky, B. «La didáctica de la historia en los continentes», Propuesta educativa, n. ${ }^{\circ}$, Buenos Aires, FLACSO, págs. 84-85; Cucuzza, H (dir.) Para una historia de la enseñanza de la lectura y escritura en la Argentina. Del catecismo Colonial a la Razón de mi vida, Luján: Miño y Dávila, 2002.

${ }^{35}$ Nota: Tanto en las estadísticas como en los padrones donde se especifica «patria» de los vecinos de Patagones, existen algunas calificaciones que son llamativas donde no solo surge la nacionalidad sino de la región, o pueblo de donde provenían: por ejemplo, Patagones, Españoles, Orientales, de Bahía Blanca, afro, Italia, etc. En el caso de Bahía Blanca, eran calificados como porteños, provincianos, españoles, ingleses, franceses, belgas, italianos, africanos, argentinos de las demás provincias.

${ }^{36}$ Hobsbawm, E. Historia del siglo XX, Barcelona: Crítica, 1995; Hobsbawm, E. Nation, nationalism since 1780, Cambridge: Cambridge University Press, 1991; Metz, C. «Imágenes y pedagogía», en: Durand, J. Análisis de las
} 
donde la nación es algo dinámico. Y en este abanico, la educación cumple un rol fundamental y las escuelas se convierten en instrumento del estado. Definen claramente identidades étnicas que comparten un mismo territorio con características lingüísticas propias. Kedourie sostiene que el idioma es el signo externo que ha diferenciado unas naciones de otras. Por lo tanto, el idioma castellano quedará reservado para una minoría instruida y el conocimiento de la lengua escrita o escrita y hablada será la premisa necesaria para ser parte de una nueva nación.

Sobre nuestra realidad Latinoamericana, historiadores contemporáneos, como Nora Souto y Fabio Waserman, refieren como el término nación hacia fines del siglo XVIII, tuvo usos y significados, en poblaciones caracterizadas por rasgos étnicos o culturales como la lengua, la religión y las costumbres. Aunque advierten sobre la amalgama idiomática observaba por Félix de Azara entre indígenas, españoles, negros, criollos. La búsqueda de una lengua que unifique evidencia la posibilidad de articular un nuevo concepto de nación. La derrota de Rosas en 1852 implicó a la nueva generación afianzar la homogeneidad étnica y lingüística ${ }^{37}$.

Juan Carlos Chiaramonte ha ahondado sobre los vocablos nación, federalismo, estado y nacionalidad atendiendo a las confusiones conceptuales elocuentes que generan diferentes anacronismos historiográficos, teniendo en cuenta que el concepto de nación era preexistente a la organización constitucional. En todas sus amplias y ricas investigaciones no ignora los diferentes usos de voces como las de nación, pueblo y soberanía. La historia como disciplina en el siglo XIX, facilitaría la reafirmación de la identidad nacional. Entiende que culto religioso podía obstaculizar la comprensión del sentido de época del lenguaje político. La escuela era el instrumento que facilitaba la aplicabilidad del concepto nación, en diferentes realidades, que lograba ser interpretada dado como estado, provincia, pueblo ${ }^{38}$.

\section{Identidad y convenciones teatrales de las fiestas mayas y julias}

En este punto pretendemos centrar nuestro análisis en el papel simbólico de las fiestas mayas y julias en este espacio llevadas a cabo por los educadores. Con ellas buscaban fortalecer en el imaginario crear en el imaginario popular la idea de nación. En Patagones donde se realzan las relaciones interétnicas en sus espacios de trabajos, presenta problemáticas a solucionar sobre la evolución de la lectura, escritura y gramática. Se observan la fuerza y particularidad que adquiere el concepto de nación a partir de un contexto histórico, signado por la fusión de españoles, criollos, indígenas, pardos y mulatos y en menor

Imágenes, Buenos Aires: [s/e], 1974 y Kedourie, E. Nacionalismo, Madrid: Centro de Estudios Constitucionales, 1988.

${ }^{37}$ Souto, N. y Waserman, F. «Nación», en: Goldman, N. Lenguaje y revolución. Conceptos políticos claves en el Río de la Plata (1780-1850), Buenos Aires: Prometeo, 2008, págs. 83-98.

${ }^{38}$ Cfr. Chiaramonte, J. C. «Conceptos y lenguajes políticos en el Mundo Iberoamericano, 1750-1850», Revista de Estudios Políticos. Nueva Época, Madrid, n. ${ }^{\circ}$ 140, 2008, págs. 11-31; Chiaramonte, J. C. Nación y Estado en Iberoamérica, Buenos Aires: Sudamericana, 2004; Chiaramonte, J. C. Ciudades, Provincias y Estados. Orígenes de la Nación argentina (1800-1846), Buenos Aires: Ariel, 1997. 
medida inglés e italiano. Para conjugar esa diversidad lingüística, la escuela se convierte en herramienta fusión cultural.

Las imágenes o símbolos proyectados facilitan la identificación de una cultura con una historia común. La gesta de Mayo se convirtió en una de ellas que permitió a los educadores generar la pertenencia a una nación o en un principio a un estado.

En recordación al 25 de mayo de 1810 en su Diario a la expedición al Desierto en 1833 y frente a las costas del río Colorado: «...el señor General en un discurso lacónico pero expresivo recapituló los recuerdos gloriosos que traen en pos de sí el 25 de Mayo y los padres de la patria que dieron el primer grito de libertad...se leyó enseguida la orden anterior y se retiraron las tropas a rezar el rosario» ${ }^{39}$.

Doña Carmen Correa de Guerrero, vecina de Patagones, destaca con sus palabras distintos aspectos que hacían hacia formas de sociabilidad durante las fiestas patrias y el carácter relevante del maestro de escuela, del juez de paz y del vecindario:

Era la época de Rosas. Fue el último baile que se dio en la casa de D. Eusebio Campos. Había invitado a las familias de Mercedes de Patagones y Patagones. Todos teníamos que asistir por obligación. La sala estaba bien adornada; al frente en uno de los extremos estaba colocado el cuadro de Rosas; entre banderas, custodiado por un guardia con un fusil en el hombro.

Tocaba el piano el maestro de Escuela Don M. Zambonini y Federico Rial. Todas las niñas llevábamos vestidos coloreantes (sic) de gasa y seda, con un moño de cinta punzó en la cabeza. Los hombres llevaban una cinta punzó en el ojal del saco con el letrero «iVivan los federales Mueran los salvajes unitarios! Esa noche bailamos hasta las tres de la mañana. Se bailó el ««minué federal», el «minué de la costa», cuadrillas y otros bailes. Don M. Zambonini era un gran pianista... ${ }^{40}$.

Zambonini no solo había sido organista de la capilla, sino además poeta y creador de un coro y profesor de español de los extranjeros que vivían en la ciudad.

En Bahía Blanca, la educadora italiana Adela Casati, esposa de Felipe Caronti, se destacaba también por ser una eximia intérprete de piano. El piano constituía un instrumento de alta valoración social y su interpretación facilitaba la formación de reuniones, tertulias u otros sistemas de sociabilidad. En especial en estos centros urbanos aislados.

En la inauguración del primer edificio escolar del pueblo, el 9 de julio de 1861, según las memorias de Felipe Caronti, su señora preparó a los alumnos más adelantados para el cántico del Himno Nacional «el cual fue ejecutado repetidas veces»» ${ }^{41}$.

José Piccioli, educador de Bahía Blanca, fue quien impulsó que la inauguración se hiciera en esa fecha, fundamentando la necesidad de realizar la fiesta en ese momento, «al ver amenazada la bandera

\footnotetext{
${ }^{39}$ Ramírez, M. S. «Identidad y convenciones teatrales en las Fiestas Mayas y Julias en el Sudoeste Bonaerense», en: Burgos, N. Modernización e identidad. Tensiones, disyuntivas y conciliaciones en la Historia y Literatura Hispanoamericana, capítulo I, Bahía Blanca: Ediuns, 2011, págs. 7-13.

${ }^{40}$ AHCP, Documento facilitado por el director del mismo profesor Héctor Bustos.

${ }^{41}$ Anales de Educación Común, n. ${ }^{\circ}$ 23, agosto de 1861.
} 
de la libertad por esos verdugos de la humanidad, por esos profanos que por espacio de tantos años...han llevado el desolamiento(sic) y la consternación en esta heroica tierra de libres». Fueron partícipes de la fiesta el juez de paz, el comandante militar y los comisionados Sixto Laspiur y José M. Araujo. Los alumnos llevaban pancartas realizadas por el preceptor con leyendas como «Rivadavia. La escuela es el secreto de la prosperidad de los pueblos»y «Sarmiento. Ley de erección de escuelas $1858{ }^{42}$.

Caronti y Laspiur, ratifican la elección de ese día atendiendo a las «miras de progreso que animan a nuestro gobierno en un pueblo tan distante de la capital». Podemos examinar los recursos utilizados tanto discursivos como las imágenes a través de carteles, que cumplen proverbialmente el papel de eslabones de un metalenguaje, con evidencias en carteles que confirman la adhesión a un modelo, del pasado y su continuidad en Sarmiento.

La cintilla punzó fue reemplazada por la bandera nacional, como símbolo identidad nacional para la ritualidad escolar. En recordación del 25 de mayo en el año 1855, y en el primer aniversario de la Constitución Bonaerense en el pueblo de Patagones los alumnos de la escuela de varones frente a la pirámide que se levantaba frente al fuerte se presentan para conmemorar el día vestidos con el traje la Guardia Nacional, «ceñidos con un banda azul y blanca teniendo en su centro la bandera nacional...» ${ }^{43}$.

Los niños en la Ciudad del Carmen participan con poesías escritas de autores locales como «Al Sol de Mayo», cuyo autor era el doctor Francisco Baraja, como una forma de identidad, de sentimiento nacional unívoco, legitimado como modo de pertenencia local.

En la recopilación realizada en fuentes documentales no se observa participación en los actos escolares de indígenas, aunque sí lo harán quienes integran los estratos sociales más altos o sujetos cuyas prácticas culturales o científicas los ubicaban en otra jerarquía.

Recién en 1862, con la llegada de los primeros religiosos protestantes de origen británico, se pretenderá a través de una misión educar en la lengua y costumbres a los aborígenes como un intento de integrarlos a la educación «formal» ${ }^{44}$. Estos misioneros aspiraban a aprender la lengua indígena para luego poder instruirlos. Esta situación encontró en un principio gran resistencia por parte de la población. A pesar de ello, no estaban lejos de la concreción de un «discurso común» para una nación propia. Parafraseando a Foucault, el discurso está constituido por el conjunto de secuencia de signos y estos luego se convierten en enunciados. Imprescindibles para romper paulatinamente con las estructuras conformadas por estas sociedades fronterizas donde los «lenguaraces» requerían una incorporación definitiva de esta marginación educativa, uya raíz principal eran diferentes formas de comunicación con el concurso de un escribiente.

En junio de 1869, un documento permite visualizar la imagen inicial en el sudoeste bonaerense de una nación integrada: Antonio Malaver a cargo del ministerio de Gobierno se dirige al juez del partido de

\footnotetext{
${ }^{42}$ Idem

${ }^{43}$ Cfr.Sanchez Ceschi, E. Crónica histórica de Carmen de Patagones entre los años 1852-1855, Buenos Aires: Tor, 1937, págs. 128-129.

${ }^{44}$ AHCP, Libro de Actas del Concejo Deliberante de Patagones.
} 
Patagones, enviando el Decreto sobre la obligatoriedad de colocación de banderas nacionales en los edificios públicos y particulares en los días de conmemoración patria ${ }^{45}$.

Lo analizado compone un conjunto de discursos educativos y evocativos de fechas patrias que oscilan entre las prácticas de la etapa rosista a los enunciados propios y singulares a partir de 1852 donde no está ausente la pedagogía política en virtud de nuevas formas de constitución de un estado. Se imponen ahora en las festividades nuevas formas de una nación necesaria para la cohesión política.

La unificación lingüística fortalecería la idea de nación bajo un mismo idioma, ante el peligro de una balcanización cultural propia de espacios altamente extensos e incomunicados.

\section{Edificios escolares, suscripciones y vecindad}

En otras oportunidades hemos tratado el concepto de vecindad. En este punto pretendemos mostrar el carácter activo que muestran ante la urgente necesidad de contar con un espacio adecuado donde pudiera desarrollarse la práctica docente. Pretendemos mostrar cómo los vecinos asentados en espacios fronterizos, fueron agentes activos en la protección y búsqueda edilicia en los pequeños poblados como modelo comunitario donde interactuaban con comandantes, jueces de paz y posteriormente con los municipios.

Tanto en el discurso como en la práctica se pueden graficar tipos de identidad comunitaria, vínculos de la historia cultural y política de esas pequeñas poblaciones, haciéndose eco de las necesidades educativas de esas sociedades.

Uno de los primeros ejemplos eran las suscripciones: los educadores de campaña eran receptores de suscripciones monetarias que recibían de los padres de los alumnos para el sostenimiento escolar. Este factor los llevaba a cuestionamientos - en algunos casos - al manejo de esas sumas de dinero, recibiendo las respectivas reprimendas por el tesorero de la Municipalidad. El juez de paz de Bahía Blanca, Gerónimo Calvento, informa al tesorero de la municipalidad Eustaquio Palao que el maestro de escuela Juan González no ha mantenido una buena conducta «al perder algún dinero en los naipes», en un faltante de dinero de la suscripción ${ }^{46}$.

No solo debían hacerse cargo de las suscripciones de los alumnos sino que además recibir donaciones para pagar a quienes trabajaban en la refacción de viejos edificios que debían adecuarse para habilitarlos como escuelas. Según se pueden constatar en las planillas de pago, la mano de obra, siendo los indígenas y los pardos o mulatos quienes actuaban como albañiles.

Los vecinos Palao, Laudelino Cruz, y Juan Plunket fueron quienes integraron la primera comisión encargada de suscribir fondos para una escuela. Ellos al dirigirse al juez de paz Calvento, fundamentan su pedido en el consiguiente adelanto que una escuela generaría al pueblo. A pesar de ello, no encuentran en los vecinos el eco necesario: «son tan inconsiderados que se niegan a ayudarle y tan poco patriotas para fomentar el Pueblo en el que viven al cual deben ser gratos, tanto bien han adquirido una

\footnotetext{
${ }^{45}$ AHCP, Año 1869, Expediente n. ${ }^{\circ}$ 238, Folio 6, Caja 3.

${ }^{46}$ AHMBMBB, 11 de enero de 1855.
} 
familia, cuanto deben sus fortunas, alegando que no pueden contribuir con $\$ 5$ por que sus hijos son muy pequeños» ${ }^{47}$.

Esta suscripción respondía a la petición del rector de la universidad y jefe del departamento de escuelas, enviada en febrero de 1854, a la justicia de paz de Bahía Blanca a quien ordena la formación de una comisión encargada de la construcción de bancos y mesas necesarias para una escuela de varones.

Barros Pazos, a cargo del departamento de escuelas, le agradece a la comisión los esfuerzos realizados «desinteresados y patrióticos» para contribuir al sostén de la escuela. Aunque les informa que será el Estado el encargado de sufragar los gastos de la misma desde enero inclusive sin que sea necesario solicitaran erogación a los vecinos. Este punto es un momento de quiebre donde existe la expresa manifestación por parte del gobierno de Buenos Aires del sostenimiento de la educación gratuita, anticipo de la futura Ley de Educación Provincial de 1875.

En abril de 1857, el juez de paz Julio Casal informa a Domingo Faustino Sarmiento, que el pueblo carece desde hace un tiempo de maestro de Escuela Pública: «... siendo de una grande necesidad por los muchos niños que hay en esta... sin poder recibir ninguna clase de educación tan necesaria en estos Pueblos de Campaña...». En el original de este documento se enfatiza con mayúsculas las palabras «pueblos» y «campaña», Notamos un discurso cuyo significado descriptivo está relacionado a su vez con una unidad lingüística que tiene que ver con circunstancias sociales teniendo en cuenta el poder del emisor, la función que ocupa y la procedencia geográfica.

Dos meses después Casal dice haber recibido la nota del señor Sarmiento que «prueba los buenos deseos que lo animan la educación de este destino» ${ }^{48}$. Casal ratifica la actitud de Sarmiento en cuanto a la buena recepción que tuvo en el vecindario sobre todo al comprometerse en enviar un preceptor a tan larga distancia de nuestra Capital.

Informa también sobre las dificultades que existen para conseguir edificios adecuados para que funcione una escuela en el pueblo. A pesar de ello, Casal le advierte a Sarmiento que se ha alquilado una casa cuyo propietario era el señor Calvento por el valor de cuatrocientos pesos por mes. Si bien el edificio no tenía grandes comodidades para el objeto al que va a ser destinado, resultaría suficiente para instalar la escuela de varones.

La legión había sido alojada por disposición del juez de paz Calvento, en febrero de 1856 en el corralón del edificio destinado para la Escuela perteneciente al Estado. La ocupación de este edificio significó la inmediata reacción de Valentín Alsina a cargo del ministerio de Guerra, la acción inconsulta del juez de paz. Las necesidades perentorias de la Legión Agrícola obligaron al coronel Olivieri a pasar por encima las limitaciones burocráticas y ocupar temporariamente el edificio No obstante, el ministro de Guerra Bartolomé Mitre instará por carta a la resolución del problema edilicio en el término de un año. Los integrantes de la Legión italiana contaron con idéntica dificultades en conseguir instalaciones apropiadas en esta aldea de la cesa campaña, concluyendo con la imposibilidad de las autoridades de desalojarlos.

\footnotetext{
${ }^{47}$ AHMMBB, 25 de octubre de 1854.

${ }^{48}$ AHPBARL, DGE, Año 1857, Carpeta 225- 5223-28, junio 41857.
} 
La llegada de inmigrantes, carros y ganados no tenía relación con las necesidades edilicias que se presentaban para recibir estos nuevos habitantes. La entrega de tierras — según Sarmiento - al otro lado del río Negro, tendría por objeto llevar inmigrantes franceses, como se había realizado con la Legión Agrícola.

En cuanto a los edificios escolares, las leyes del 8 de agosto de 1857, la del 31 de agosto y de 1858 y específicamente la Ley de Erección de Escuelas, fechada el 14 de septiembre de 1859, que llevaba la firma de Mitre y de Domingo Faustino Sarmiento, establecía en su artículo $3^{\circ}$ que los jueces de paz solicitarán el terreno adecuado para la construcción de edificios escolares, siendo condición precisa que la localidad habría de suministrar el terreno.

El juez de paz de Patagones, es uno de los primeros que requiere objetos que son imprescindibles para un buen adelanto de la escuela y la suma de mil pesos que era el costo de los mismos. La descripción de la escuela es una muestra del estado de estos establecimientos en la campaña bonaerense: «...pues la casa donde se halla establecida la escuela no tiene una sola puerta vidriera lo que hace indispensable el vigor de la estación durante las horas de la Escuela con notable perjuicio, no solo de la salud sino del adelanto de sus estudios...».

Según el informe de este juez de paz, a los niños les resulta imposible concentrarse. Otras de las necesidades que plantea Miguel está en la el tamaño del establecimiento (mayor extensión del aula), proveer de libros y útiles indispensables para «...facilitar este recurso á muchos jóvenes que la pobreza de sus padres o tutores no se los permiten».

El Municipio le hace conocer a Barros Pazos que sabe que en otros departamentos de campaña han recibido útiles, «los repetidos golpes que por las invasiones de indios ha sufrido este departamento no le deja recurso alguno...» ${ }^{49}$.

El juez de paz de Patagones, Francisco Baraja, le informa a Sarmiento, en setiembre de 1858, el «estado ruinoso» en que se encuentra la casa donde funciona la Escuela en ese partido, requiriendo de doscientos pesos mensuales para repararla. Denuncia y subraya que los doscientos pesos que deberían haber sido destinados para la escuela nunca fueron cobrados porque la casa en la que está la escuela proviene de un legado. La propuesta del juez de paz es que ese dinero en lo sucesivo se entregue ahora y después mensualmente a la municipalidad para que sea destinado para los gastos del establecimiento escolar.

La Municipalidad manifiesta su confianza en la acción que hasta ese momento lleva a cabo el Departamento de Escuelas. Comisiona para percibir la primera remesa al señor Domingo Murga, quien «prestará un servicio a este vecindario, que por otra parte no puede costear por la pobreza en que ha quedado reducida en la pasada devastación de indios bárbaros» ${ }^{50}$.

Baraja, el 31 de diciembre de 1858, como juez de paz y presidente la municipalidad de Patagones, informa de la concesión de premios pero que la partida del buque desde Buenos Aires a este puerto, hizo que no se recibieran. «como había costeado por su cuenta unos libros para cimentar aquellos, resolvió el que firma distribuirlos por cuanto la Escuela estaba próxima a entrar en vacaciones».

\footnotetext{
${ }^{49}$ AHRLPBA, Dirección General de Escuelas, Carpeta n. ${ }^{\circ} 2101$, marzo a octubre, 4889-27.

${ }^{50}$ AHPBADGE, Carpeta n. ${ }^{\circ} 2924$, n. $^{\circ}$ 6983-36, 1 de septiembre de 1858.
} 
Según Baraja, la entrega de premios se realizó con total solemnidad, según describe este testigo, luego de una ceremonia en la iglesia parroquial a la que asistieron autoridades y todo el vecindario. Se presentaron a recibir los premios los treinta y cinco alumnos «en proporción al mérito adquirido en sus clases respectivas».

Los discursos que dos jóvenes alumnos pronunciaron, el desembarazo y urbanidad de sus maneras y el orden que allá reinaba llamo la atención de los concurrentes, y honra de un modo muy favorable a este lejano Pueblo ${ }^{51}$.

El juez de paz pondrá de manifiesto que estos logros en los alumnos responden a la dedicación del «ilustre Preceptor que dirige esta escuela señor Dn. Mariano Zambonini». Cargo que ejerce desde hace 15 años en forma consecutiva.

Baraja, concluye la nota en un claro mensaje hacia las autoridades centrales: «Terminaré felicitando al Señor Geje del departamento de Escuela por este feliz resultado suplicándole que si lo tiene á bien, se digne enviar los Premios que en este año estaban destinados á esta juventud la que todavía espera este galardón que la Patria dedica» ${ }^{52}$.

En Bahía Blanca, también existieron diferentes dificultades para la construcción de un edificio que fue alentado por Caronti y Sixto Laspiur. El primero de ellos donde funcionó la escuela de varones fue destinado con posterioridad a la Legión Agrícola. La propiedad había pertenecido al vecino Gascone, sitio donde hoy se levanta el palacio municipal. En 1854, este edificio previo a la llegada de la legión había sido convertido en cárcel.

En 1860, se dispone que la Municipalidad haga entrega del terreno ubicado en la plaza Argentina, que pertenecía a la fábrica de la Iglesia, precisamente donde estaba ubicado el emblemático edificio del diario La Nueva Provincia. El juez de paz Benjamín Basavilbaso será el encargado de comunicar esta decisión de las autoridades del Departamento de Escuelas, en octubre de 1860.

El edificio constaba de dos salones, uno para la escuela de varones y otro para la de niñas, sumado a las habitaciones destinadas para el preceptor y preceptoras.

Quedará a cargo de la escuela de varones el preceptor José Piccioli. Este educador recibió un amplio reconocimiento de la sociedad bahiense y de uno de los más destacados biógrafos como Domingo Pronsato, quien sostiene que

...enviado por Sarmiento el ciudadano italiano Jose Piccioli casado con Rafaela Leiva, hija del Comandante Manuel Antonio Leiva, se dio entero a la enseñanza primaria, atendiendo con su esposa una de las primeras escuelas de Bahía Blanca ${ }^{53}$.

\footnotetext{
${ }^{51}$ AHPBADGE, Carpeta n. ${ }^{\circ} 2924$, n. ${ }^{\circ}$ 6983-36, 1 de septiembre de 1858.

${ }^{52}$ AHPBADGE, Carpeta n. ${ }^{\circ} 2924$, n. ${ }^{\circ}$ 6983-36, 1 de septiembre de 1858.

${ }^{53}$ Pronsato, D. op. cit., pág. 85. Su nombre figura en la lista de miembros de la tropa de Regimiento de Blandengues de Frontera, Segunda Compañía, Padrón de 1836, Inv. 14-5-36. AAMMBB.
} 
Este educador, según su correspondencia, aplica para enseñar a los niños el método Scully, propicia poder introducir la educación en tribus de «indios amigos», como una forma de evitar las enfermedades que los diezmaban y busca generar espacios de sociabilidad en la vecindad para participar en las reuniones del «Club de la Unión», primero de Bahía Blanca.

Piccioli se haría cargo luego de abandonar su cargo el educador Justo Villanueva, quien en nota dirigida al doctor Barros Pazos, quien presenta su renuncia, aduciendo razones de salud de sus padres y hermanas.

Oficialmente, será el 27 de noviembre de 1861, cuando Manuel Pazos le informe al ministro de Gobierno Pastor Obligado que el edificio mandado a construir con destino a la escuela de Bahía Blanca ha sido concluido.

La obra se había ejecutado, al igual que la de Lomas de Zamora y San Martín, con sujeción a planos e instrucciones dadas por el Departamento y en las mejores condiciones de arquitectura de las escuelas. Según consta en los Anales de Educación, la de Bahía Blanca fue encargada a los señores Laspiur y Caronti siendo su costo de cien mil pesos. Esta prevista para que sirva para escuela de ambos sexos, conteniendo dos salones y seis piezas para maestros.

...este pueblo poseía el Departamento una casa que fue donada por un vecino con destino á escuela, en ella funcionó la de varones, hasta la época en que llegó a ese destino la Legión Militar... ${ }^{54}$.

A partir de ese momento se dejaría de pagar los cuatrocientos pesos de renta para funcionar en edificio propio.

Dentro de los reclamos edilicios, observamos como los preceptores hacían suya la necesidad de reparación o de brindar mejores condiciones a sus alumnos. El preceptor de Bahía Blanca, Justo Villanueva al presidente de la Municipalidad, en 1858, el arreglo de tres bancos y otros útiles:

Como he recibido órdenes de dar exámenes el 24 del corriente, y para este acto es de suma e imperiosa necesidad disponer el local de un modo digno y adecuado al efecto, cuento con la cooperación de la Municipalidad, cuanto de aquellos vecinos que por su carácter y patriotismo se prestarán a dar a sus auxilios ${ }^{55}$.

Planos y presupuesto del edificio fueron realizados por Miguel Barrabino, quedando bajo la responsabilidad del juez de paz la inversión y control de fondos.

Piccioli con carta que dirige a Sarmiento con fecha 13 de junio de 1861 le informa que la inauguración se realizará el 9 de julio. También comunica sobre la renuncia de Basavilbaso y su reemplazo por el vecino Mauricio Díaz.

\footnotetext{
${ }^{54}$ Anales de Educación Común, Volumen III, 1 de diciembre de 1861, n. ${ }^{\circ}$ 25, págs. 5-6.

${ }^{55}$ AHMMBB, 9 de noviembre de 1858.
} 
El Capitán Felipe Caronti en su discurso inaugural sostendrá que «la libertad se difunde y consolida por la instrucción pública». Los bloques significativos que se observan en este texto facilitan la comparación llana y profunda de su pasado en Italia, Suiza y Alemania, al «formular el voto de que en un país libre y civilizado como éste, la instrucción primaria sea obligatoria», por cuanto los pueblos educados en la campaña impedirían las intrigas y mentiras del caudillismo ${ }^{56}$.

La edificación escolar, nos obliga a reflexionar la riqueza de las simbolizaciones ligadas a determinados edificios o espacios habilitados para ser destinados a las escuelas y los emplazamientos reservados para ellas en nuestro territorio bonaerense hacia 1850. Debemos tener en cuenta que el espacio arquitectónico expresa una visión del mundo y la posición del hombre frente a él. Si observamos la evolución que existe desde los primeros reclamos por un edificio adecuado hasta su concreción, existe una nueva relación con el contexto cultural que se produce tras la caída de Rosas sobre todo en la campaña del sudoeste. Nuevas formas de «urbanismo» escolar están vinculadas con una nueva organización racional del espacio público, donde los edificios escolares son gravitantes. Las instituciones escolares responden a poner bajo control e inspeccionar al alumno.

Por otro lado, la escuela constituye un centro de sociabilidad vecinal porque no solo construye vínculos y adhesiones económicas para la construcción edilicia, sino, parafraseando a González Bernaldo, aunque no evoque una comunidad histórico territorial, aparece vinculada a la comunidad política. En el caso específico de la frontera, estos vínculos, están dados con las autoridades municipales pero fundamentalmente con el juez de paz. La sociabilidad es un rasgo de vida colectiva. Y en este caso la escuela es objeto y objetivo que vincula a los vecinos, que los hace sociables a favor del bien público $^{57}$.

\section{Conclusión parcial}

Entre 1852 a 1871, en el período conocido de «consolidación nacional» se destacaron cambios estructurales en los distintos niveles de la enseñanza pero particularmente en la educación elemental o primaria.

En este capítulo hemos observado cómo se fueron definiendo los instrumentos legales para el cumplimiento de un modelo de país. La fractura que el mismo sufre durante una década entre la Confederación y Buenos Aires, permitió que sea esta última quien diseñara por su papel hegemónico en la economía, en la política y en su cultura, la gestión gubernativa y la política educacional de los presidentes Mitre, Sarmiento y Avellaneda.

Sarmiento es centro y «pretexto», como lo definiría Martínez Estrada, para reflexionar no solo sobre nuestra «nacionalidad», sino hacedor de la educación del estado de Buenos Aires y también del espacio de la provincia que nos ocupa.

\footnotetext{
${ }^{56}$ AHPBARL, Departamento de Escuelas, Legajo 52, n. ${ }^{\circ} 4519$.

${ }^{57}$ Cfr. González Bernaldo, P. «El Río de la Plata. 1820-1862», en: Guerra, F.-X. y Quijada, M. Imaginar la nación, Cuadernos de Historia Latinoamericana, n. ${ }^{\circ}$ 2, Berlín: AHILA, 1994, págs. 179-213.
} 
El Plan Combinado de Educación Común fue el hilo conductor a la Ley de Educación de la provincia de 1875 y de la Ley n. ${ }^{\circ}$ 1420. Fue el camino y el vínculo de transformación social del territorio bonaerense.

Los enunciados «orden y progreso» propios de esta generación, se materializan en ciertas regularidades enunciativas de vecinos, educadores y actores sociales tanto en sus prácticas cotidianas como en sus lecturas.

Las fiestas mayas y julias nos permitieron comprobar las tensiones que se generan entre la ruptura de convenciones políticas y las modificaciones ideológicas que introdujo el pensamiento liberal. Tensiones entre dos mundos o microespacios que las sobreviven y observan un lento desplazamiento en imágenes y construcciones ideológicas en sus formas de socialización educativa y que giran a la conceptualización de patria y nación.

No quisimos obviar en este capítulo el tema edilicio porque desde el punto de vista simbólico por cuanto es señal y símbolo del valor que un estado le atribuye a la educación. La participación de la vecindad en la búsqueda de terrenos, en mejorar el bienestar de los alumnos dentro del ámbito escolar, es un indicador de un compromiso y adhesión a un nuevo modelo educativo. Genera nuevos espacios de sociabilidad en una comunidad histórico territorial disociada con el norte y centro de la provincia demostrando un impulso colectivo por escoger la forma y arquitectura de edificios escolares adaptados al clima y a la geografía que los rodea. 


\section{Capítulo 4}

\section{Anticipos a la Ley de Educación Común de 1875}

\section{Estadísticas y censos}

El clima de organización constitucional del Estado como cuestiones centrales bajo el lema de «orden y progreso» exigieron la redefinición de estrategias y de instituciones que permitan analizarlas cuantitativamente. Ante las incógnitas resultaba necesario establecer variables independientes. Estas permitirían dar resolver en el mapa bonaerense y fundamentalmente en la frontera Sudoeste, el cuadro de situación, los instrumentos a utilizar y responder a las necesidades educativas diversas.

Para Oszlak la formación de un estado es un aspecto constitutivo del proceso de construcción social. En este conjunto se definen nuevos planos y componentes que estructuran la vida social organizada. El resultado dependerá de los recursos movilizados por diferentes actores - entre ellos el Estado- y las formas de resolverlos. Esta estatidad supone una organización del poder y de las formas de dominación política ${ }^{1}$. Quienes comienzan a gobernar a partir de 1854, expresan su interés por la lectura e interpretación de datos en referencia a la sociedad y el panorama educativo, enfoque de un análisis funcional que crea un paradigma de un enfoque que facilite la observación, la investigación y la formulación de nuevas metodologías pedagógicas.

Nuevas lógicas de funcionamiento en el campo intelectual determinan la creación de instituciones que respondan a una nueva política educativa a desarrollar. En octubre de 1854 se crea una comisión de educación que correspondía a ilustración y moral de las escuelas de primeras letras. Un año después se crea el Consejo de Instrucción pública bajo la dependencia del rector de la universidad. Ante la falta de fondos propios, Sarmiento a cargo de la jefatura de escuelas decide la venta de las propiedades de Juan

\footnotetext{
${ }^{1}$ Oszlak, O. «Reflexiones sobre la formación del Estado y la construcción de la sociedad argentina», Desarrollo económico. Revista de Ciencias Sociales, n. ${ }^{\circ}$ 84, Vol. 21, enero-marzo, 1982, Buenos Aires: IDES, págs. 531547.
} 
Manuel de Rosas. Pero según sostiene el autor, a pesar de los conflictos internos entre Buenos Aires y la Confederación, el número de escuelas y educandos fue creciendo ${ }^{2}$.

En tanto, en la región del sudoeste, desde lo discursivo entre autoridades centrales y locales, se observa usos léxicos nuevos que propician la observación y conocimiento de profesión, ingresos, nivel de escolaridad, propiedades, número de animales (ganado vacuno, lanar y equino), tipo de viviendas, conformación familiar, de los centros urbanos. Puede leerse en los Anales:

Hoy en el presupuesto de los gastos, figura en el Mensage (sic) del gobierno de la Provincia, la beneficencia y la educación, confundidas, mientras que son dos objetos muy diversos; la educación es un medio político, un ramo estadístico, pertenece a la Economía Política y Social...la beneficencia es un objeto secundario ${ }^{3}$.

La educación se convierte en una cuestión de estado, con un sistema político centralizado que define el gobierno y el poder central según sus objetivos políticos, económicos o sociales.

En octubre de 1862 Mitre había sido elegido presidente de la Nación, presentando su renuncia como gobernador de Buenos Aires. Designando como ministro de Justicia, Culto e Instrucción Pública al doctor Eduardo Costa. Mariano Saavedra, hijo del presidente de la Primera Junta será nombrado gobernador de Buenos Aires. .

A propuesta del poder ejecutivo, la campaña de la provincia, fue dividida en distintos nuevos partidos, muchos de ellos cercanos a la región analizada, respondiendo a un nuevo Departamento de Departamento de Topografía Estadística creado 1850 que era continuidad del de $1826^{4}$. Estos cambios, estarían acompañados por el fomento de la extensión ferroviaria y la multiplicación de escuelas de campaña.

La primera evaluación estadística en esta etapa que se observa con mayor claridad es la de los Anales, en su Informe de 1860, que se visualiza bajo la cuestión ¿Por qué hay menos escuelas si la población ha aumentado? Y ¿por qué hay menos alumnos si hay mayor número de niños? Esta estadística le permite tener un panorama del número de niños que se educan en la provincia y en la campaña.

\begin{tabular}{|c|c|c|c|}
\hline Número de alumnos & 1860 & 1864 & Diferencia \\
\hline \multirow{2}{*}{ Escuelas públicas de varones } & Ciudad: 2446 & Ciudad: 2813 & +369 \\
\hline & Campaña: 2358 & Ciudad: 2866 & +508. \\
\hline \multirow{2}{*}{ Escuelas particulares de varones } & Ciudad: 2893 & Campaña:2245 & -650 \\
\hline & Campaña:702 & Campaña: 472 & -230 \\
\hline
\end{tabular}

Fuente: Anales de Educación común en la Republica Argentina, Volumen III, 30-8-1865, pág. 17.

En marzo de 1865, Pablo Cárdenas desde el ministerio de Gobierno de Buenos Aires y por orden del Jefe del Departamento de Escuelas, solicita al señor Juez de Paz del Partido de Bahía Blanca, envía un

\footnotetext{
${ }^{2}$ Barba, F. E. «La ley de Educación común de Buenos Aires de 1875», Trabajo y comunicaciones, n. ${ }^{\circ}$ 18, La Plata, 1968, págs. 53-65.

${ }^{3}$ Anales, op. cit., Volumen III, Buenos Aires, 30 de agosto de 1865, pág. 16.

${ }^{4}$ Gautreau, P. y Garavaglia, J. C. op. cit., págs. 63-96.
} 
comunicado en el cual solicita tener un conocimiento actual de la educación pública y de sus necesidades para organizarla. Los datos aportados serían necesarios para elevar al gobierno un «informe sobre el número de Establecimientos de Educación en todo el Estado ya sean públicos o particulares, número de alumnos de ambos sexos, extensión, ramos y textos de enseñanza». Este comunicado indicaba que eran excluidas de esta medida la Universidad, la Escuela de Medicina y los Seminarios. Se otorgaba al Jefe del Departamento de Escuelas la suma de mil pesos para la impresión de planillas ${ }^{5}$.

Con la firma de Pastor Obligado, en febrero de 1865, se le envía al Presidente de la Municipalidad de Bahía Blanca planillas impresas que debían ser distribuirlas a preceptores y preceptoras de escuelas particulares, informando datos de alumnos. Según consta en este informe, Bahía Blanca no tenía escuelas particulares ${ }^{6}$.

En 1868, la escuela de varones de Bahía Blanca había tenido un progresivo aumento de su población — como vimos con anterioridad - pero según dichos de los vecinos Sixto Laspiur y Francisco Bozzano, miembros de la Comisión municipal «para el examen de los alumnos de la Escuela de Varones de este pueblo á cargo del señor Preceptor Dn. Juan Ruibal...» han examinado uno a uno todos los alumnos en los diferentes ramos que abraza la enseñanza y en general hemos quedado satisfecho del estado próspero de esta escuela, bajo la ilustrada y asidua contracción de su digno preceptor «...recordará que hace poco tiempo que el personal de la Escuela apenas se componía de unos quince niños en un estado lamentable de atraso y notará que hoy con la confianza que justamente ha inspirado el nuevo Preceptor en los padres de familia, ascendiendo a cuarenta y uno» ${ }^{7}$.

Es decir, desde marzo de 1856 cuando se inician las actividades de la escuela de varones con quince niños, en 1867 el número llegaba a 46 alumnos.

Este informe elevado al presidente de la municipalidad Don Mariano Méndez, destaca que el aumento de niños en seis meses en la escuela y duplicar su número se debía a la «contracción del Preceptor, y el de la municipalidad» contesta el director de Escuelas Luis J. de la Peña ${ }^{8}$.

Previo al inicio del censo de 1869, José Manuel Estrada jefe del departamento de escuelas envía un comunicado a los presidentes de las municipalidades solicitando datos precisos a fin de recabar de todos los establecimientos de educación, sean públicos o particulares, de niños o niñas, datos como número de niños existentes en el municipios en edad de ser educados, número de escuelas, capacidad de las mismas, número de escuelas sostenidas por el gobierno, quienes las sostienen (municipio, subsidios); número de niños educados en cada escuela, ramos enseñados, textos empleados para la enseñanza de cada ramo, gastos de la escuela, datos de los maestros y horario de las escuelas.

\footnotetext{
${ }^{5}$ AHMMBB, 7 de marzo de 1865.

${ }^{6}$ AHMMBB, 21 de febrero de 1865.

${ }^{7}$ AHMMBB, 23 de septiembre de 1868.

${ }^{8}$ Nota: Este educador nacido en Buenos Aires en 1795, estudio en el Colegio de San Carlos, doctorándose en la Universidad de Córdoba en filosofía y teología. Durante el gobierno de Rosas tuvo que exiliarse y se desempeño como educador en Brasil y en Montevideo. En 1865 fue designado miembro del Consejo de Enseñanza Pública. Mantienen una profusa correspondencia con Juan María Gutiérrez sobre temas de relaciones exteriores y de educación fundamentalmente durante la etapa que cumple como autoridad educativa de la provincia de Buenos Aires.
} 
En este punto, se observa el control sistemático que lleva el gobierno central y provincial. Según lo manifiestan, el gobierno de la provincia tiene cien mil niños en estado de educarse, entendiendo que «la estadística educacionista es la brújula del lejislador (sic) y del Estadista», puede leerse en los Anales. La mirada no está puesta solo en la educación pública sino en la privada y en su control.

La cuestión de la captación numérica y estadística indica cierto acercamiento a nuevas teorías que intentan acercarse hacia los métodos de las ciencias naturales que le permitirían analizar la estructura de una sociedad, los «hechos» y sus conexiones con determinadas cuestiones sociales para pensar un modelo educativo adecuado ${ }^{9}$. Hacia mediados del siglo XIX observamos el fortalecimiento de una burguesía ideológicamente fuerte, cuya libertad democrática permitiría su autonomía económica. La educación y el conocimiento serán instrumento de las grandes transformaciones por ellos apostadas.

A partir de la década del setenta, se observa un mayor control sobre las escuelas particulares. En marzo de 1872 Antonio Malaver, a cargo del ministerio de Gobierno, se dirige al Juez de Paz de Patagones solicitando que informe sobre el número de escuelas particulares existentes en el partido, el número de niños y niñas que asisten y el gasto que dichas escuelas ocasionan ${ }^{10}$.

Antonio Zinny a cargo del departamento General de Escuelas, se dirige al Presidente de la Municipalidad de Patagones informando que ha tomado conocimiento «que algunos Preceptores y Preceptoras, que de él dependen, suelen practicar más o menos largas ausencias de sus respectivas escuelas, con perjuicio de la instrucción que les les está encomendada... ${ }^{11}$. Ruega que tenga a bien llamar la atención del señor Municipal a quien compete sobre se punto de tan vital interés. «Un preceptor, dirá más adelante, no debe jamás abandonar su puesto sino por motivos justificados y siempre con conocimiento de la autoridad de quien depende». Solicita Zinny que se practiquen visitas a las escuelas para corregir este problema.

Estos documentos demuestran cómo desde los organismos centrales, se establecen nuevos dispositivos de control sobre la educación privada y una ligazón entre el crecimiento de poder de los mismos y formas disciplinares para los educadores, técnicas que permiten ajustar la producción del saber y de aptitudes en la escuela.

\footnotetext{
${ }^{9}$ Lukacs, G. Historia y conciencia de clase, México: Grijalbo, 1985, págs. 8-9.

${ }^{10}$ AHCP, año 1872, Expte. n. ${ }^{\circ} 275$, folio 11, Caja 10.

${ }^{11}$ AHCP, año 1873, Expte. n. ${ }^{\circ}$ 282, Caja 12.
} 
2. Censos de 1869: parámetros de comparación de dimensiones educativas en el sudoeste bonaerense

Censo de 1869

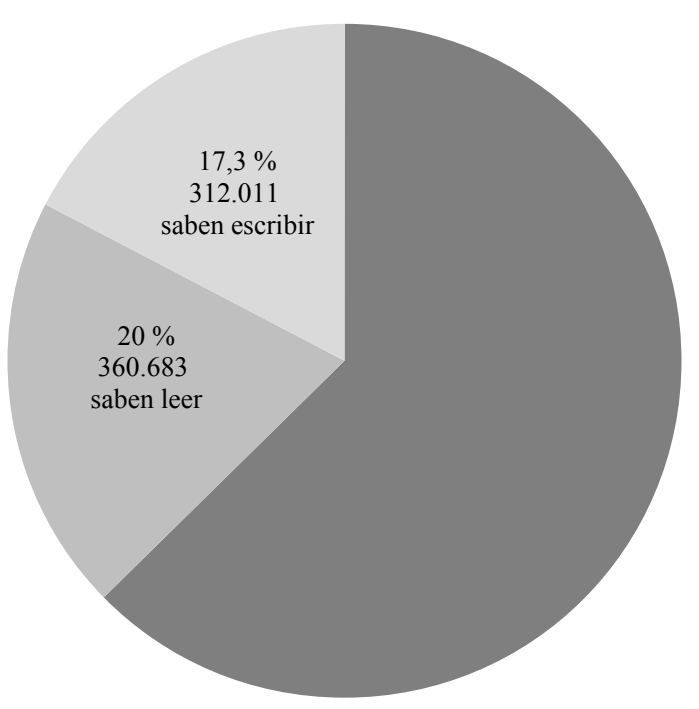

Población: 1.800.000 habitantes en todo el país.

Población en la provincia de Buenos Aires en los años 1854 y 1869

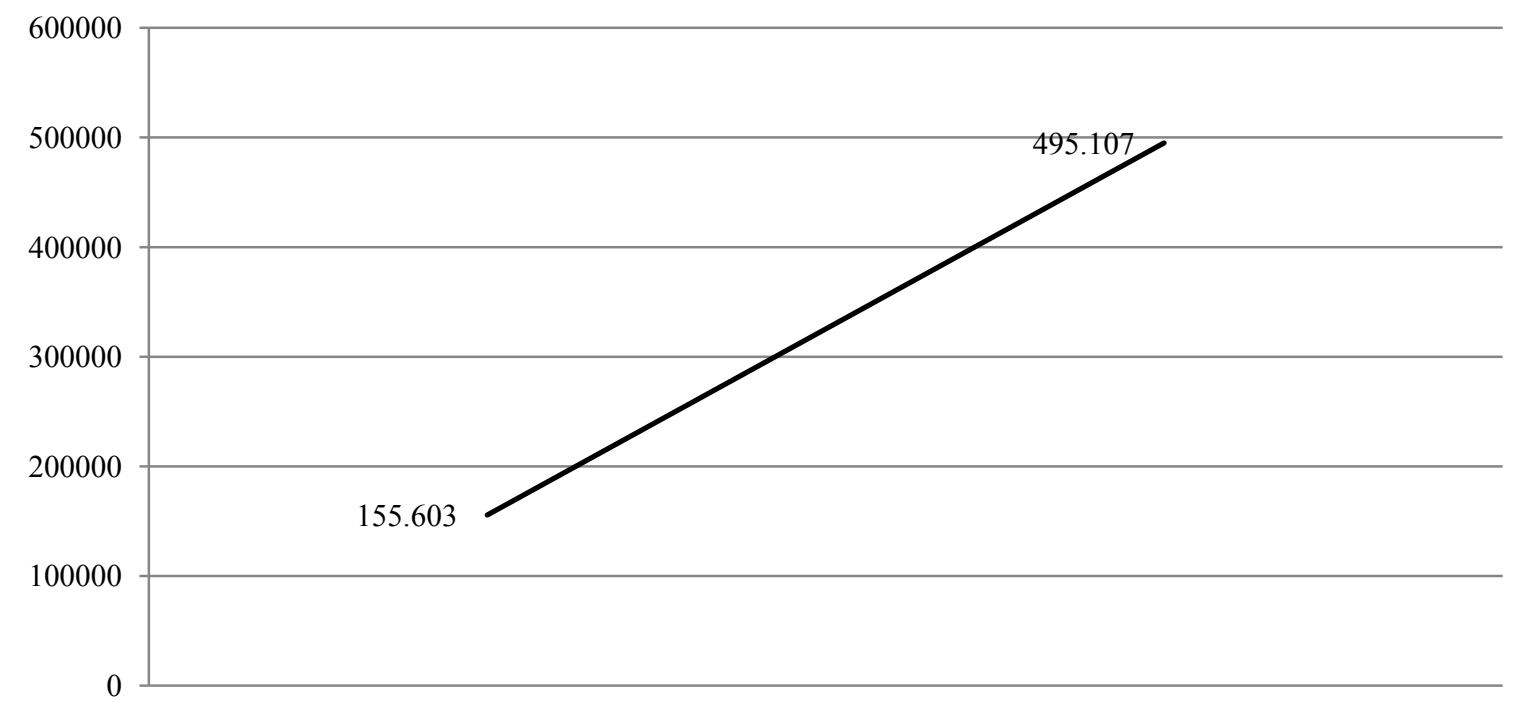


Población según estado civil, instrucción y condición especial

Argentinos

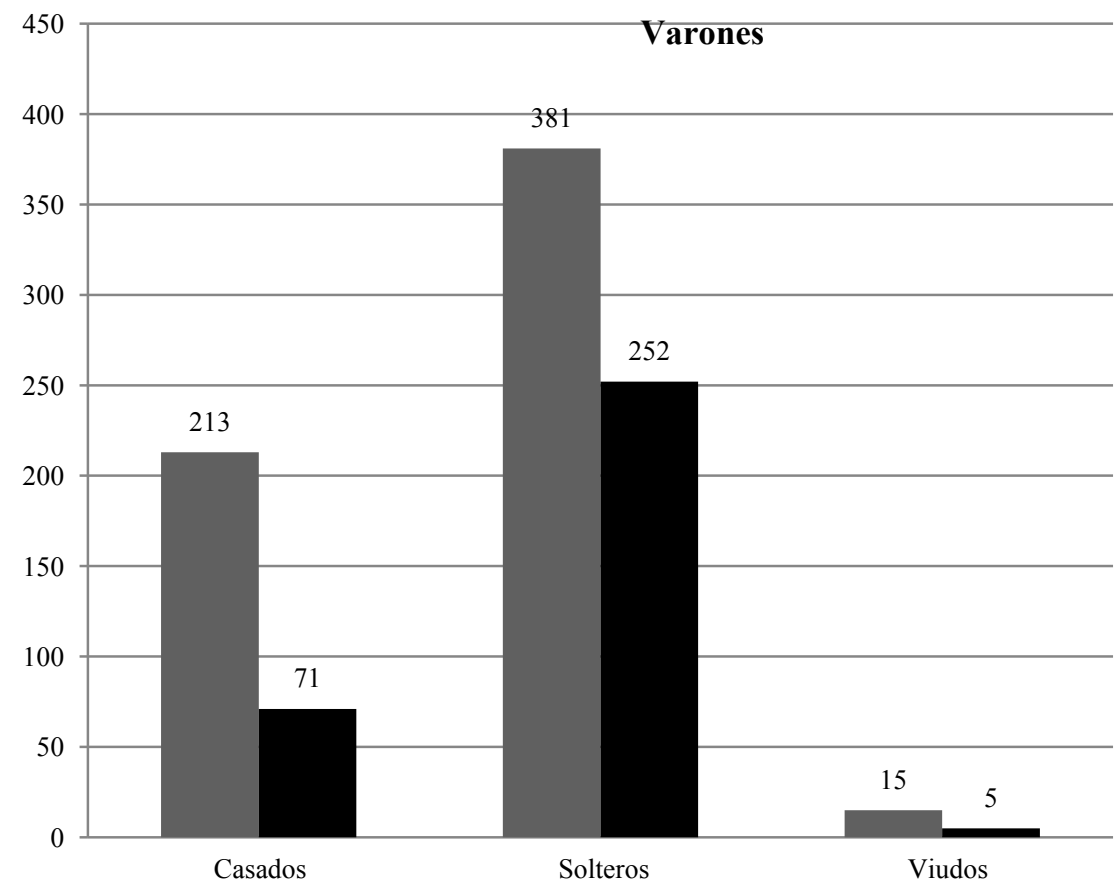

- Patagones

- Bahía Blanca

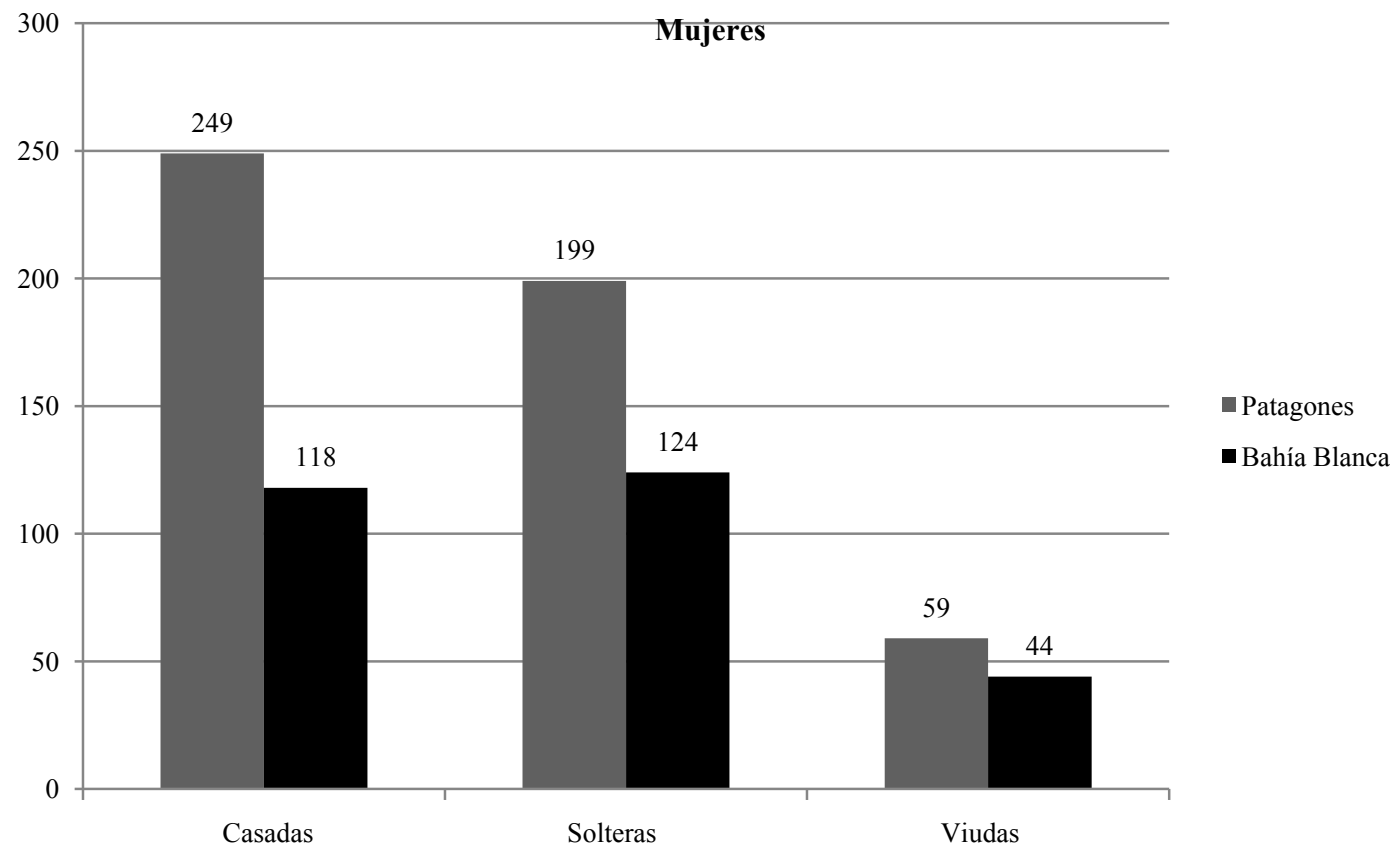




\section{Extranjeros}

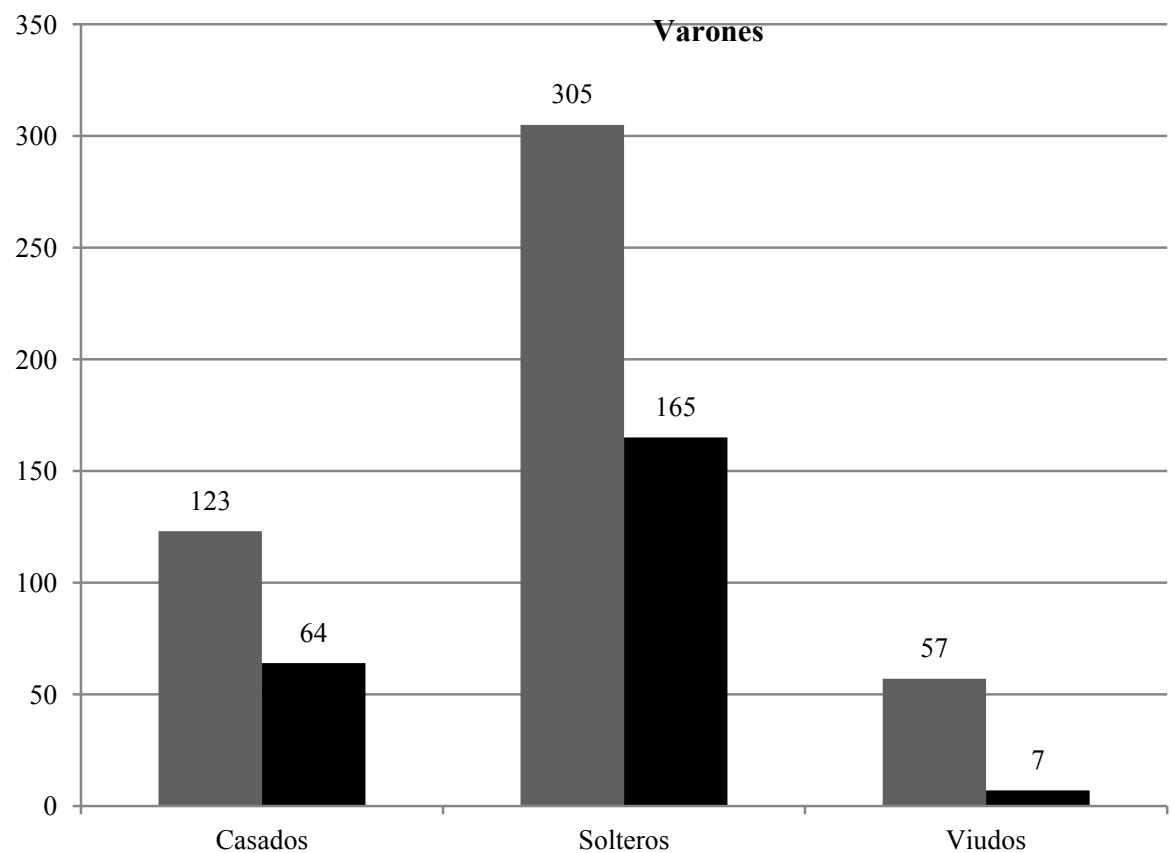

- Patagones

- Bahía Blanca

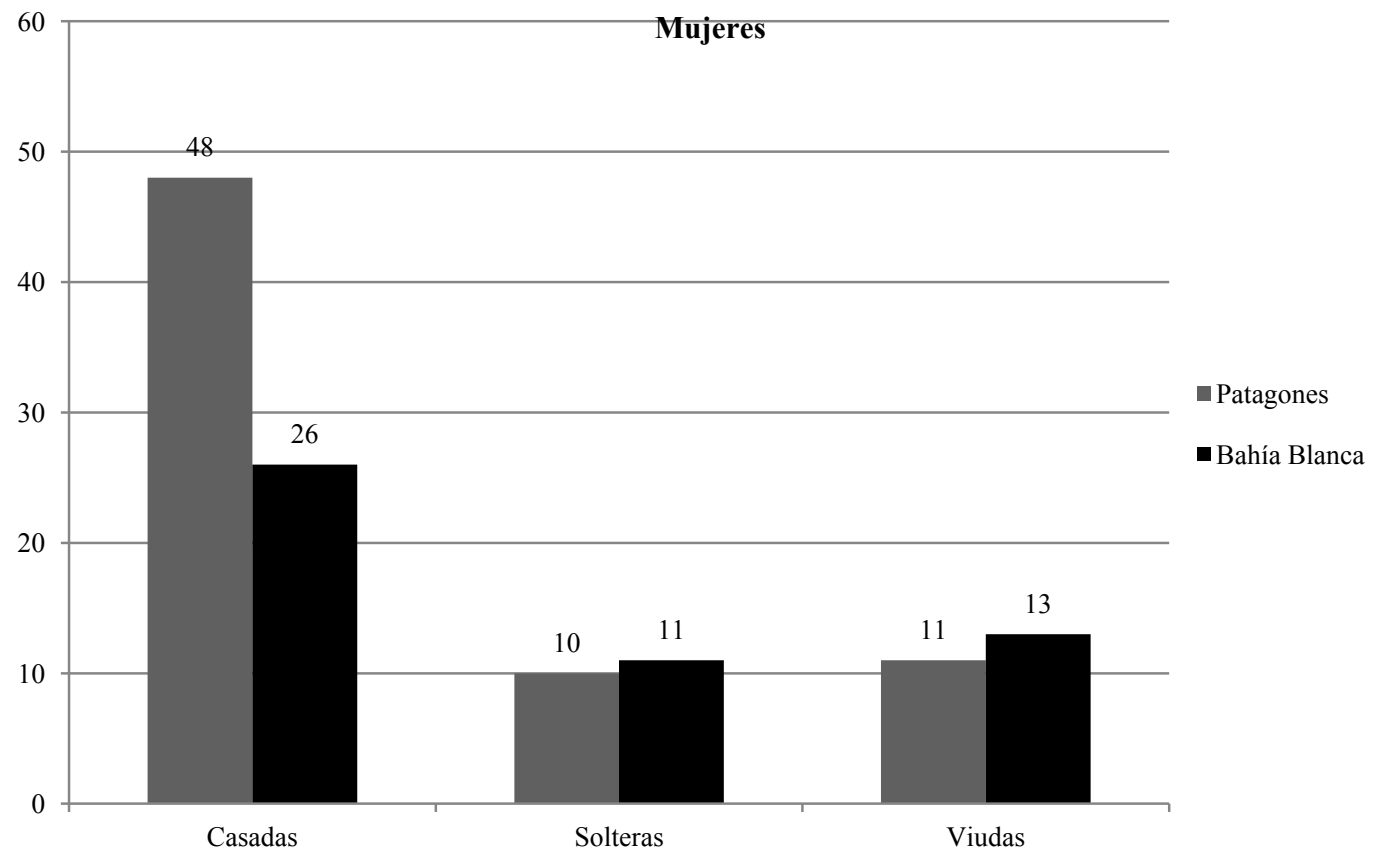


Población urbana en Bahía Blanca: 1472 habitantes
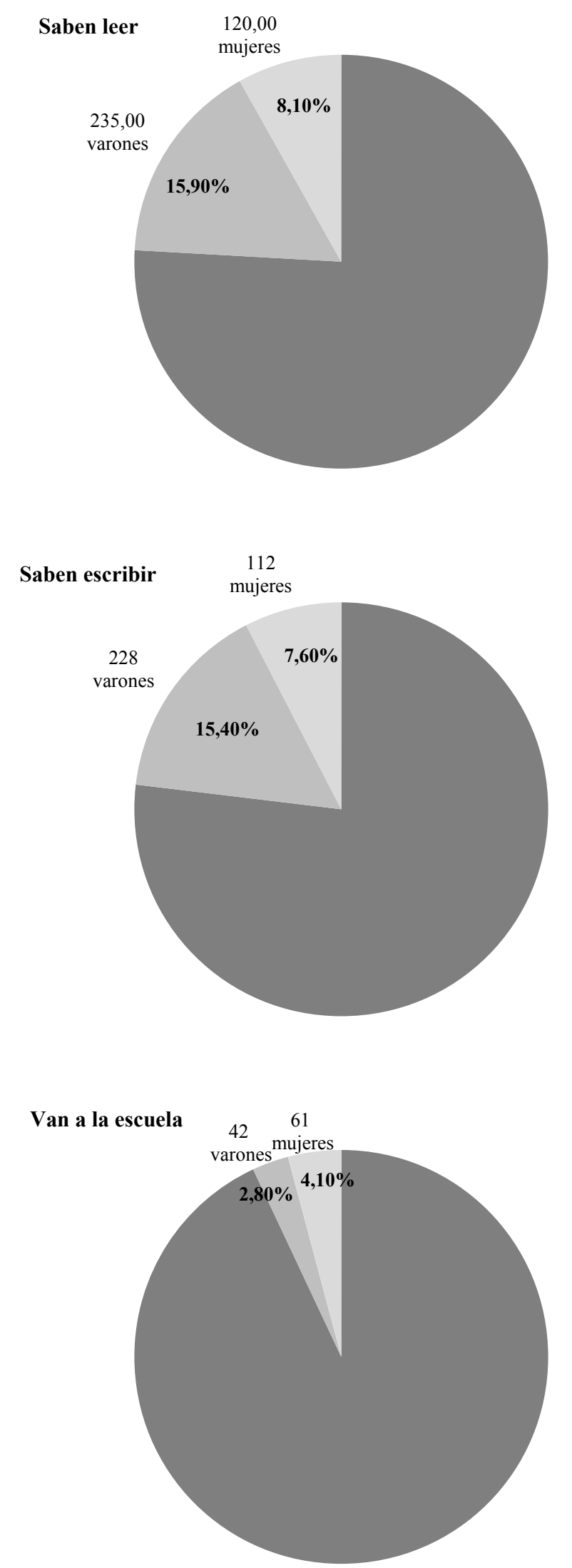
Población urbana en Patagones: 2567 habitantes

Saben leer
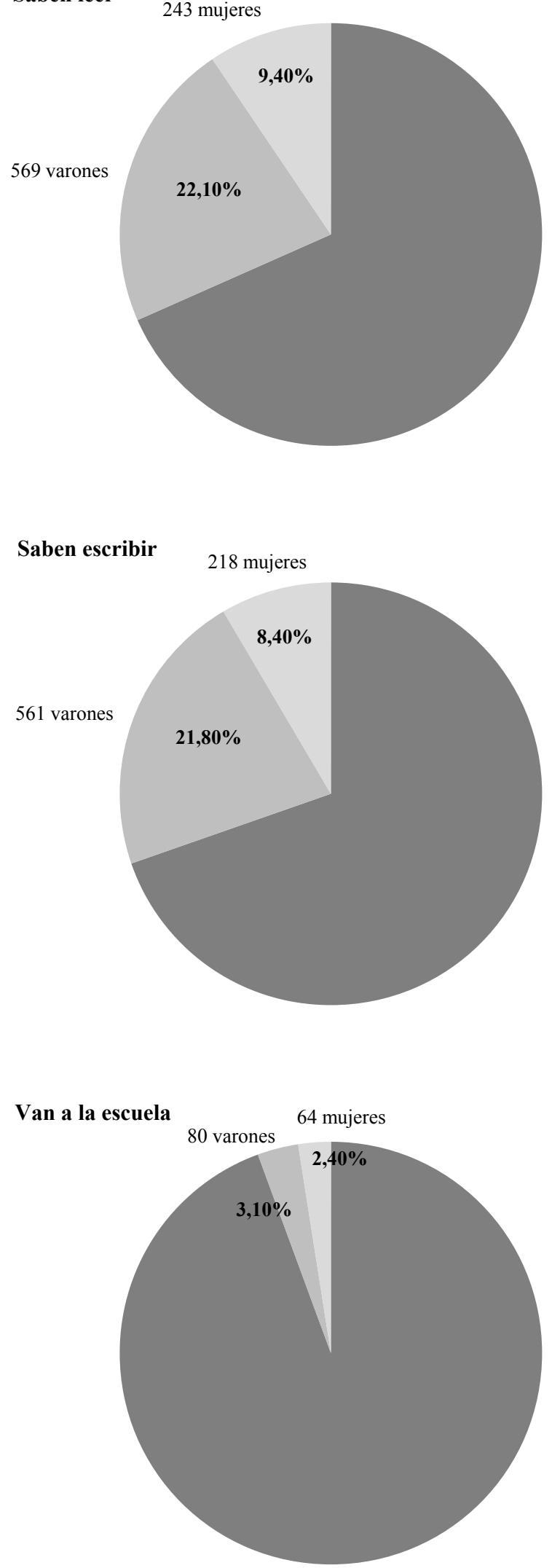


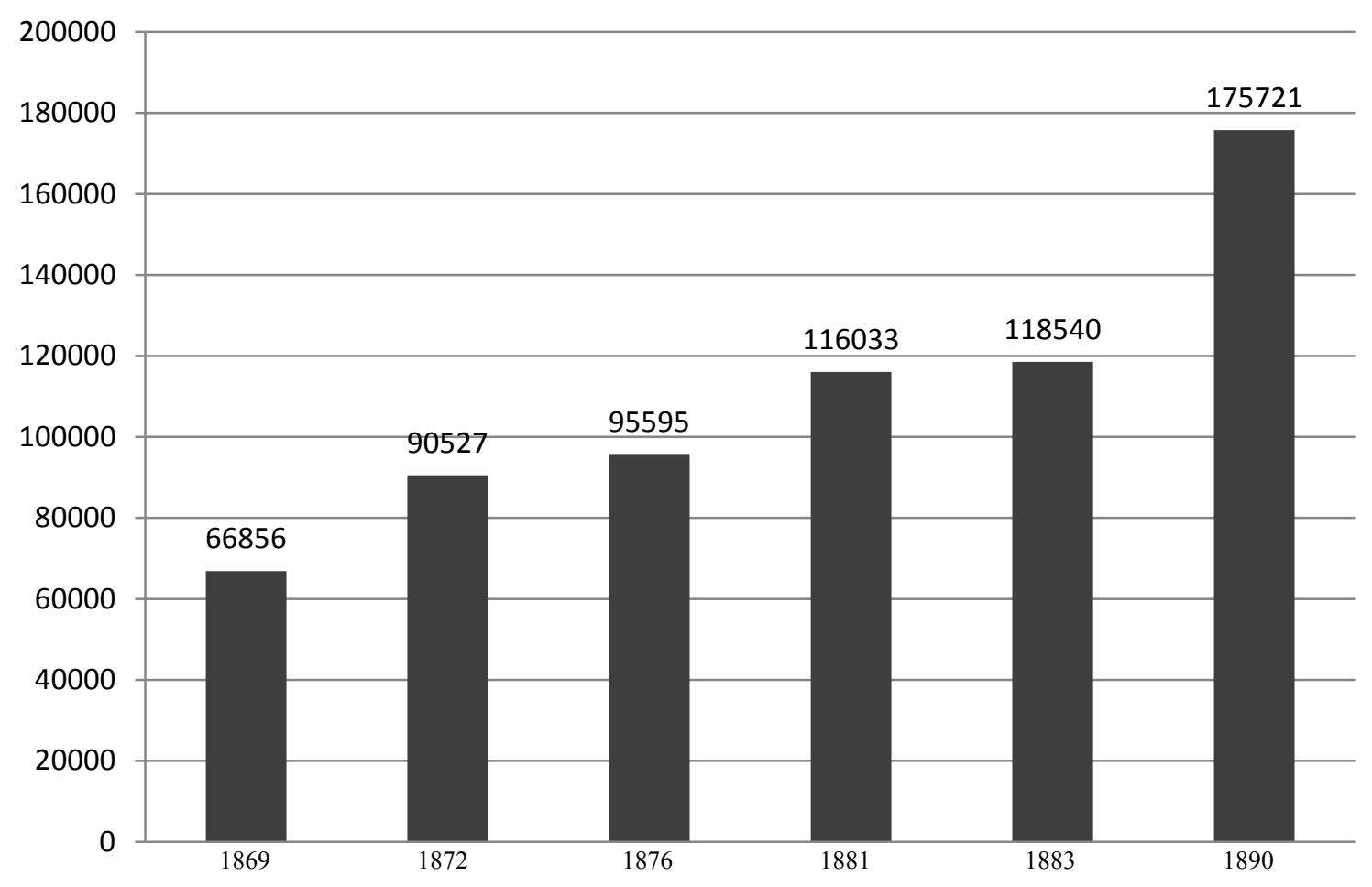

Población escolar

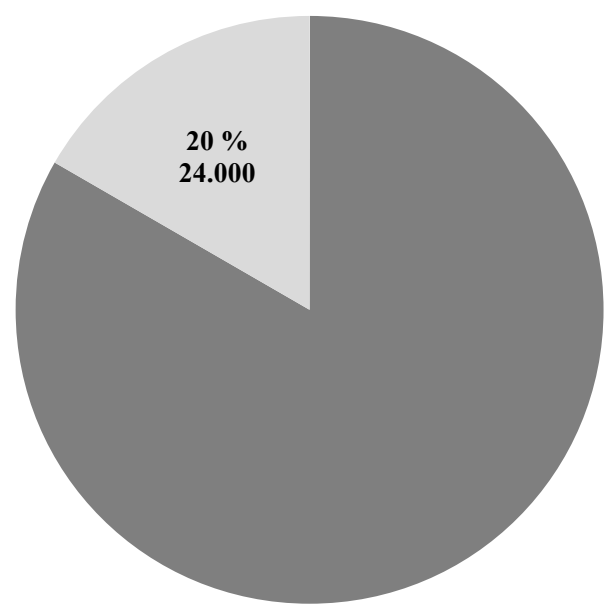

Ciudad de Buenos Aires 1856

Pob. 120.000 hab.

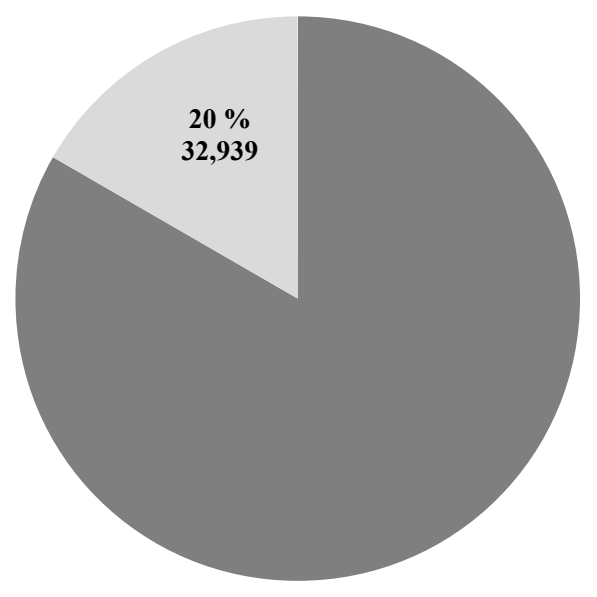

Campaña bonaerense 1856 Pob. 164.700 hab. 
Población argentina y extranjera según su grado de instrucción.

Censo nacional de 1895 - Pob. 757.756

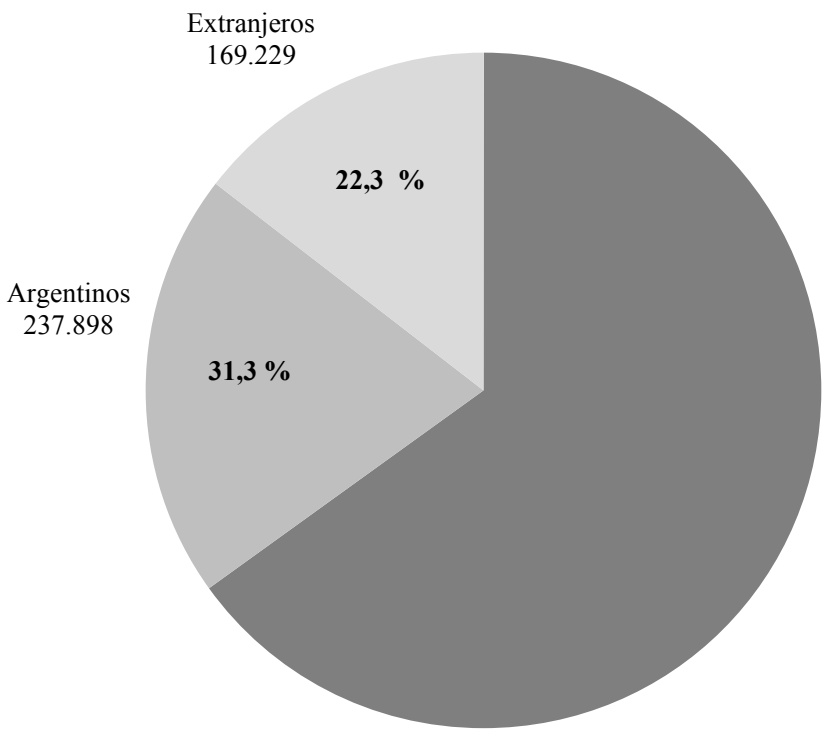

Saben leer y escribir

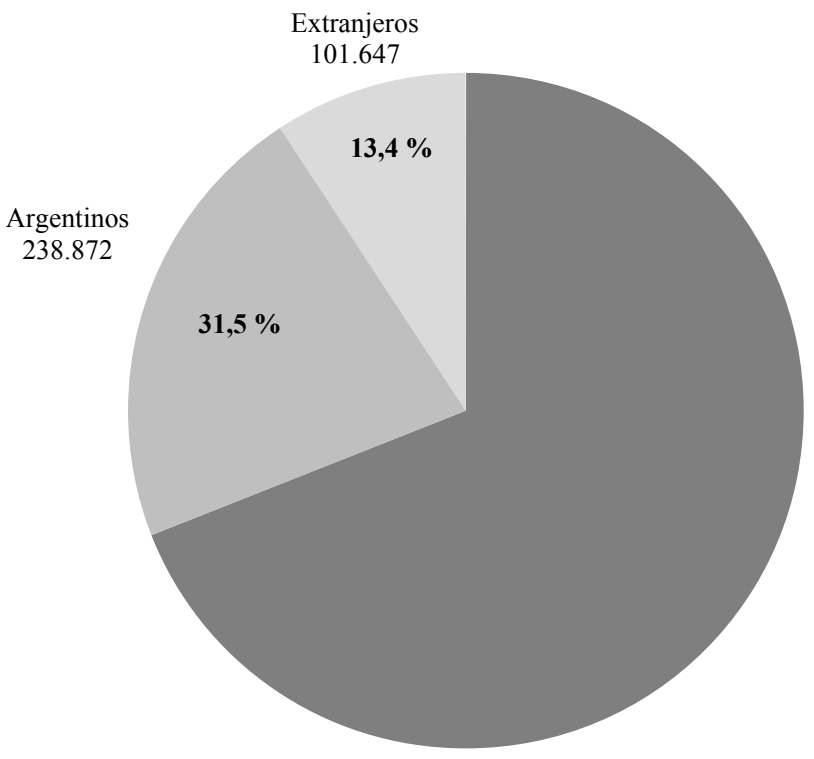

No saben leer y escribir 


\section{Conclusión}

En esta tesis me propuse analizar la educación como variable de análisis histórico social encontrando en ella un nuevo sistema de dominación que no está basada solo en las relaciones de poder económicas, sino que está unida al control político y al dominio del saber.

Siguiendo los principios de Giddens, pudimos observar como el sistema de dominación y control político y económico estaban vinculados a la producción de conocimientos. Las clases o sectores dominantes lograron imponer una ideología que las legitimaba y alcanzaron en esta dominación política y económica la dependencia material de los sectores carentes de las herramientas como saber leer, escribir y comunicar.

Logramos determinar en un amplio contexto histórico (1778-1871) quiebres y continuidades en las mentalidades educativas.

La elección de un espacio determinado en el territorio bonaerense, como es el sudoeste, me permitió interpretar por un lado la adaptabilidad de quienes lo habitaron y habitan, que debieron adecuarse constantemente a variables que transitaban desde un alta tensión en un contexto de aislamiento, dimensiones culturales en lo que respecta a identidad étnica, identificación con la cultura de acogida, evitación de incertidumbre y emociones por distancia e incomunicación con otros centros urbanos y con el poder central ante el constante peligro de ataques indígenas.

Confrontamos y contrastamos, en el marco teórico y filosófico los diferentes modelos pedagógicos que planteaban desde Buenos Aires y su aplicabilidad en un micro espacio donde la teoría pudiera ser sometida al rigor de la prueba, a través de las fuentes documentales y del discurso de los diferentes actores sociales en sus praxis educativas. Los sistemas pedagógicos que planteaban para sujetos que respondían a un patrón entendido para Buenos Aires y el territorio que lo circundaba, pero que estaba lejano a hombres, mujeres y niños de una zona de frontera, como Carmen de Patagones y la Fortaleza Protectora Argentina.

La elección del sudoeste bonaerense se debió a la particularidad que presenta este territorio aún en la actualidad. Los diferentes proyectos que partieron desde Sarmiento, Carlos Pellegrini y hasta Martínez 
Estrada, por convertir a Bahía Blanca en capital de un estado o provincia, demuestran la singularidad cultural, geográfica y económica observada por estadistas sobre una región.

En primer lugar, al analizar los parámetros fundacionales y sus dimensiones culturales de ambos centros pudimos probar cómo el espacio generó formas de adaptabilidad y de construcción de estratos o estamentos sociales. El trabajo con fuentes documentales puso a la luz la producción de textos de exploradores, colonizadores y fundadores de esta región.

Desde el punto de vista discursivo estos hombres fueron productores de conocimiento de acuerdo a las lógicas del contexto histórico que vivían. La validación de los saberes de los hombres de fines de siglo XVIII en Carmen de Patagones y hasta la segunda década del siglo XX, los jerarquizó por sus conocimientos de la técnica y de la ciencia, de la comunicación verbal y escrita. En el sentido tradicional, no podrían ser encuadrados en la definición del intelectual, pero sí en la calificación de «expertos» en diferentes áreas de la ciencia. De allí la significación que le dimos según el nivel de formación educativa a comisarios, superintendentes, escribientes, contadores, cirujanos, entre otros.

En Patagones, observamos en este primer quiebre desde el punto de vista social formas de vida precaria ante una emigración castellana y gallega forzada que los convirtió en controladores de un espacio de frontera por orden real y que tuvieron que compartir con hombres que pertenecían a diferentes grupos culturales (europeos, criollos, afroamericanos e indígenas) que por los condicionamientos ambientales, generan mayores espacios de socialización. Las relaciones entre el grupo de establecidos y las tensiones que se generan con los excluidos.

Esta sociedad de rasgos panópticos, donde inmigrantes mayoritariamente españoles, ocupan los estamentos sociales superiores permitió que estos sectores ocupen rangos militares, educacionales y jerárquicos de poder más definido, como alcaldes, comandantes y educadores o maestros. El dominio de la lecto-escritura favoreció el nacimiento de lo que Henry Giroux llama, «intelectuales transformativos». Los dominios científicos y de conocimientos produjeron a su vez ciertas exclusiones en los grupos criollos, nativos, afro-americanos e indígenas.

A diferencia de Carmen de Patagones, la Fortaleza Protectora Argentina contó en este primer momento con una sociedad producto del reclutamiento forzoso de campesinos que debieron entregarse a medios coactivos de una sociedad militarizada. Los cuadros militares que ocupan esta nueva Fortaleza está encuadrada dentro de una oficialidad «distinguida» por profesión, nivel de educación y un pasado que los representaba: las campañas libertadoras.

Para lograr un mejor análisis crítico de intelectuales y expertos de ambos centros urbanos, recurrimos a los esquemas teóricos de los modelos pedagógicos del Río de la Plata en cada uno de los contextos históricos analizados y su relación con los cambios educativos que se generaron.

El segundo quiebre en la mentalidad y prácticas educativas lo encontramos en la etapa de transición de la propuesta educativa de Rivadavia a Rosas, hasta su caída en 1852.

Este es un momento donde la intelectualidad tiende a lograr mayores especializaciones y las perfecciona. Se comprende que el saber es poder, es el que quita el miedo a los hombres y los convierte en amos de la naturaleza. 
Surgen puntos de fractura donde el Estado es el educador y la mujer adquiere protagonismo a través de la Sociedad de Beneficencia.

Durante la época de Rosas, se procura que el conocimiento responda a variables que combinan utilidad, orden y defensa de la religión.

En la primera parte, correlacionamos el proceso de militarización del fuerte de Carmen de Patagones y de la Fortaleza Protectora, comparando el componente social de sus milicias. Esto nos permitió determinar los niveles de educación de la oficialidad y la tropa de ambos centros urbanos y la relación con la estratificación social y como una nueva forma de regulación de la sociedad y el desplazamiento de un nuevo sistema de clases basado en el conocimiento. La vinculación entre el grado militar y el dominio del saber, convierte a algunos militares en educadores asistemáticos.

Este proceso también lo realizamos analizando el papel de la mujer y del hombre como educadores, estudiando y diferenciado las prácticas educativas de unos y otros en un espacio de frontera.

Los comandantes de frontera, los jueces de paz y los curas vicarios, sin perder su identidad, representan - en determinados momentos - intereses educativos excluyentes y siendo generadores de nuevas formas de conflicto. Por otra parte, conscientes que se han convertido en agentes sociales de relevancia política, deciden conducir y acompañar el proceso evolutivo de la educación de la región.

La escolaridad de determinados actores en estos dos centros urbanos permitió la construcción de redes familiares con parentesco de familias «notables» de cada población donde no estaba ajeno el nivel de educación y alcance del saber de estos actores.

Los fundamentos de la política educativa bonaerense no siempre podían ser concretados en las aulas, aunque se observa la adaptación de los educadores a esta sociedad de frontera.

En el tercer quiebre pudimos comprobar cambios estructurales que se generaron en los distintos niveles de la educación, fenómeno que fue producto de una generación que formada en el 37, define los instrumentos legales como la Constitución y leyes y reglamentos; el uso de nuevos sistemas cuantitativos como las estadísticas y censos, para materializar los enunciados «orden y progreso», acompañados por educadores y vecinos que hacen suyos estos nuevos conceptos.

A lo largo de este estudio, no solo pudimos comprobar que la fórmula sarmientina produjo profundas transformaciones que fueron decisivas no solo para el territorio de la provincia de Buenos Aires, sino que a pesar de las controversias que genera, dejó en evidencia su conocimiento de la realidad económica, social y educativa del sudoeste bonaerense. 


\section{Bibliografía}

\section{Fuentes documentales}

\section{Fuentes primarias}

\section{Archivos}

1.1. Archivo General de la Nación (AGN).

Sección Comandancia de Patagones. F.Independencia

División Nacional. Secretaría de Rosas

División Gobierno Nacional Fronteras

Dirección de Estudios Históricos del Ejército Costa Sud.

Archivo de J.J.Biedma

Archivo del General Guido

Archivo de Nicolás Descalzi

Gobierno Nacional. Secretaría de Gobierno Bahía Blanca.

1.2. Archivo Histórico de la Provincia de Buenos Aires «Dr. Ricardo Levene» Dirección General de Escuelas.

1.3. Archivo Histórico Municipal Municipalidad de Bahía Blanca

1.4. Archivo Histórico de la ciudad del Carmen de Patagones.

1.5. Biblioteca Nacional. Documentación donada. Archivo de J. J. Biedma, Sala VII.

Documentación donada, Archivo de C. Villejas, Sala VII.

Nicolás Descalzi, Sala VII.

1.6. Ministerio de Educación de la Nación, Biblioteca del Maestro, Libros de Lectura, Libros para niños del siglo XIX, Palacio Pizzurno, Buenos Aires. 


\section{Fuentes éditas}

\subsection{Publicaciones oficiales}

Primer Censo de la República Argentina, 1869, Buenos Aires, 1872.

Registro Oficial del Gobierno de Buenos Aires, 1830-1840.

Antecedentes y fundamentos del Código Rural, Buenos Aires, 1864.

Archivo Histórico de la Provincia de Buenos Aires, Historia de la Provincia de Buenos Aires y formación de sus pueblos, Ricardo Levene (dir.), Tomos I y II, La Plata, 1940.

Registro Oficial del Estado de Buenos Aires, Años 1835, 1836 y 1838, Archivo de la Provincia de Buenos Aires «Doctor Ricardo Levene», La Plata.

Mensajes de los gobernadores de la Provincia de Buenos Aires: 1822-1849, Vol. I y II, Archivo de la Provincia de Buenos Aires «Doctor Ricardo Levene», La Plata.

Mensajes del Gobierno del Estado de Buenos Aires a la Asamblea Legislativa (1855-1860).

Muzlera, J. Tierras públicas. Recopilación de leyes y decretos y resoluciones de la Provincia de Buenos Aires sobre tierras públicas, desde 1810 a 1895, Buenos Aires: Ed. Isidro Solá, [s/f].

Prado y Rojas, A. Leyes y Decretos promulgados en la Provincia de Buenos Aires desde 1810 a 1876 , Buenos Aires: Mercurio, 1877.

Constitución del Estado de Buenos Aires sancionada por la Honorable Asamblea Constituyente el 11 de abril de 1854, Buenos Aires: Imprenta Americana, 1870.

Diario de Sesiones de la Cámara de Senadores de la Provincia de Buenos Aires (Reimpresión), 1854, La Plata: Imprenta el Día, 1895.

Documentos del Congreso General Constituyente de 1824-27, Publicaciones del Archivo Histórico de la Provincia de Buenos Aires, Documento de Archivo, Tomo XIII, La Plata, 1949.

Rosas, J. M. de. Diario de la Expedición al Desierto, Buenos Aires: Plus Ultra, 1965.

Sarmiento, D. F. Obras Completas, Tomos XVIII y LXIV, Buenos Aires: Imprenta Mariano Moreno, 1900.

Senado de la Nación, Biblioteca Mayo, Colección de obras y documentos para la Historia Argentina, Tomos IV, VI, VIII. IX Primera Parte y Segunda Parte, Buenos Aires, 1960.

Pita F. Remembranzas, Carmen de Patagones y su región desde 1835 a 1890, Archivo Histórico de Carmen de Patagones, [s/f], pág. 27.

Garibaldi, G. Memorias, Biblioteca La Nación, Buenos Aires, 1910.

De Angelis, P. Colección Obras y Documentos de las Provincias del Río de la Plata, Tomos I, IV y V, 2a edición, Librería Nacional Lajouane, Buenos Aires, 1910.

Biedma, J. J. Crónica histórica del Río Negro de Patagones, Buenos Aires: Ed. Contes, 1905.

Biedma, J. J. Apuntes históricos del Río Negro seguidos de una brevísima reseña de sus más importantes pueblos, Viedma, 1887.

Un Inglés, Cinco años en Buenos Aires (1820-25), Buenos Aires: Hyspamérica, 1986.

Municipalidad de Bahía Blanca, Digesto Municipal de la ciudad de Bahía Blanca, 1869-1909, Publicación oficial, Bahía Blanca, 1910. 


\subsection{Publicaciones de la época}

Alvaro Barros, Fronteras y territorios federales de las Pampas del Sud, Buenos Aires, 1872.

Ansay, Felipe. «Relación de los padecimientos y ocurrencias...», en: Biblioteca de Mayo, Tomo IV, Buenos Aires, 1960, págs. 3400.

Archivo del General Mitre. Presidencia de la República, Años 1862-1868, Buenos Aires, Biblioteca de la Nación, 1913, Tomo XXIII.

Archivo del General Mitre, Cartas confidenciales de varios sobre diversos asuntos, Biblioteca La Nación, 1912, Tomo XV.

Beccaria, Cesare. De los Delitos y de las Penas, Buenos Aires: EJEA, 1958.

Berra, Francisco. Estado de la enseñanza común en la provincia de Buenos Aires, 1894.

Biedma, José J. Apuntes históricos del Rio Negro seguidos de una brevísima reseña de sus más importantes pueblos, Viedma, 1887.

Biedma, José Juan. Crónica histórica del Río Negro de Patagones, Buenos Aires: Ed. Contes, 1905.

Casati, Adele; Caronti, Juan y otros. Felipe Caronti 1813-1883 A la memoria de Felipe Caronti, Buenos Aires: Kraft, 1884.

Cramer, Ambrosio. «Reconocimiento del Fuerte del Carmen del Río Negro y de los puntos adyacentes de la Costa Patagónica», en: De Angelis, Pedro. Colección de Obras y Documentos relativos a la Historia Antigua y Moderna de las Provincias del Rio de la Plata, 2a edición, Tomo IV, Buenos Aires: [s/e], 1910.

Cuello, Juan. Informe de la Comisión de Bahía Blanca sobre Inmigración, Agricultura, Ganadería y Comercio, Departamento General de Inmigración, 1887.

Darwin, Carlos, Viaje de un naturalista alrededor del mundo, Buenos Aires: El Ateneo, 1942.

de Angelis, Pedro. Acusación y defensa de Rosas, comp. Rodolfo Trostiné, Buenos Aires: La Facultad, 1946.

Ducós, Ricardo G. Historia documental y gráfica de la ciudad de Bahía Blanca. 1828-1928, [s/1]: Imprenta López, 1928.

Groussac, Paul. «Los dos fundadores de Bahía Blanca». Separata de Humanidades. Tomo XIV. Buenos Aires: Coni, 1926.

Lemèe, Ricardo. La escuela y la biblioteca en la provincia de Buenos Aires, La Plata: [s/e], 1898.

Caronti, Luis. Documentos relativos a la fundación de Bahía Blanca, Buenos Aires: Talleres Gráfico Centenario, 1884.

Documento para la Historia de Bahía Blanca, Tomo 1, Bahía Blanca, Instituto Tecnológico del Sur, 1951.

D Orbigny, Alcide. Viaje a la América meridional realizado entre 1826 a 1833. Brasil, República del Uruguay, República Argentina, la Patagonia, República de Chile, República de Bolivia, República del Perú, Buenos Aires: Futuro, 1945.

García, Pedro Andrés. «Diario de un viaje a las Salinas Grandes en los campos del Sud de Buenos Aires», en: de Angelis, Pedro. Colección de Obras y Documentos relativos á la Historia Antigua y Moderna de las Provincias del Río de la Plata, Tomo II, Buenos Aires: Lajouane, 1910.

Monti, Antonio. La vita e le memorie del patriota Comasco Filippo Caronti, Milano: Coenobium, 1918. 
Sarmiento, Domingo Faustino. Educación Común en el Estado de Buenos Aires, 2a. edición, [s/1]: El censor, 1887.

Viedma, Antonio. «Diario de un viaje a la Costa de la Patagonia para reconocer en donde establecer poblaciones», en: de Angelis, Pedro. Colección de Obras y Documentos relativos á la Historia Antigua y Moderna de las Provincias del Río de la Plata, Tomo V, Buenos Aires: Editorial Lajouane, 1910.

Undiano Gastellu, Sebastián. «Proyecto de traslación de las fronteras de Buenos Aires», en: de Angelis, Pedro. Colección de Obras y Documentos relativos á la Historia Antigua y Moderna de las Provincias del Río de la Plata, Tomo I, Buenos Aires: Editorial Lajouane, 1910.

Zeballos, Estanislao. Un viaje al país de los araucanos, Buenos Aires: [s/e], 1881.

\subsection{Publicaciones periódicas}

Anales de Educación Común en el Estado de Buenos Aires, Vol. II y III, Buenos Aires, 1860, 1865, 1866, 1867, 1868, 1869, 1870, 1871.

Anales de Educación Común de la Republica Argentina, Editados por Juana Manso, Vol. IX, 1870.

Archivo Americano y Espíritu de la Prensa del Mundo, 1843-1851, 1a reimpresión del texto español conforme a la edición original, Tomos I y II, Buenos Aires: Editorial Americana.

Historia documental y gráfica de la ciudad de Bahía Blanca. 1828-1928, Buenos Aires: Imprenta López, 1928.

The British Packet and Argentine News, 1828 a 1848, Buenos Aires.

Gaceta Mercantil, 1833 a 1848, Buenos Aires.

Revista Argentina, Vol. 1 a 13, Buenos Aires, 1868 a 1872.

La Tribuna, 1853 a 1861, Buenos Aires.

Diario La Época, 1882.

Diario La Nueva Provincia. Centenario de Bahía Blanca.

Revista de Educación, Publicación Oficial del Consejo General de Educación de la Provincia, Año II, marzo 1883, n. ${ }^{\circ}$ XXI.

Zinny, Antonio. Estudios biográficos, Estudio Preliminar de Narciso Binayán, Buenos Aires: Hachette, 1958.

\section{Bibliografía específica}

Achaval, Nicolás. Memoria del estado de educación común durante el año 1882 en la Provincia de Buenos Aires, Buenos Aires, Consejo General de Educación, 1883.

Alberini, Coroliano. Problemas de la historia de las ideas filosóficas en la Argentina, La Plata, Facultad de Humanidades y Ciencias de la Educación, 1966.

Araque, Adriana. «Contacto afro-hispánico en la comarca Viedma-Carmen de Patagones: relaciones sociales y fórmulas de tratamiento», en Hipperdinger, Yolanda (comp.) Contacto de Lenguas en el Sur Argentino, Bahía Blanca: Ediuns, 2009.

Alliaud, Andrea. Los maestros y su historia: los origenes del magisterio argentino, Buenos Aires: CEAL, 1993. 
Adorno, Theodor y otros. Teoría crítica del sujeto, México: Siglo XXI, 1986.

Altamirano, Carlos. Intelectuales, Notas de Investigación, Buenos Aires: Norma, 2006.

Angenot, Marc. El discurso social. Los limites históricos de lo pensable y lo decible, [s/1]: [s/e], [s/f].

Banzato, Guillermo y Lanteri, Sol. «Forjando la frontera. Políticas públicas y estrategias privadas en el Río de la Plata», Historia Agraria, n. ${ }^{\circ}$ 43, Murcia, diciembre, 2007, págs. 435-458.

Barba, Fernando. «La Ley de Educación Común de Buenos Aires de 1875», Trabajos y Comunicaciones, Universidad Nacional de la Plata, La Plata, 1968.

Barba, Fernando. «Nota sobre las tierras de Patagones y Río Negro», en: Segundo Congreso de Historia Argentina y Regional, Vol. 1, ANH, Buenos Aires, págs. 319-317.

Barba, Fernando. «Los primeros reglamentos de Educación Primaria de Buenos Aires, 1816-1818», en: Temas de Historia Argentina II, Instituto de Historia Argentina Ricardo Levene, Facultad de Humanidades y Ciencias de la Educación, Universidad Nacional de La Plata, La Plata, 1997, págs. 716.

Barba, Fernando. «En torno a los Reglamentos de Educación Primaria de Buenos Aires. 1816-1818», en: Cuarto Congreso de Historia de Los pueblos de la Provincia de Buenos Aires, Tomo I, AHPBA, Mar del Plata, 1993, págs. 25-36.

Barba, Fernando. «Algunos aspectos relativos al poblamiento de Carmen de Patagones», Trabajos y comunicaciones, n. ${ }^{\circ}$ 24, 2 a época, Facultad de Humanidades y Ciencias de la Educación, Universidad Nacional de La Plata, La Plata, 1996, págs. 133-145.

Barba, Fernando Enrique. «Pobladores y empleados de Carmen de Patagones 1779-1810», en: Separata del Sexto Congreso Nacional y regional de Historia Argentina, Academia Nacional de la Historia, Buenos Aires, 1997.

Barba, Fernando Enrique. Frontera ganadera y guerra con el indio. La frontera y la ocupación ganadera en Buenos Aires entre los siglos XVIII y XIX, UNLP, La Plata, 1995.

Barral, María Elena. «Las parroquias rurales, clero y población en Buenos Aires durante la primera mitad del siglo XIX», Anuario IEHS, Tandil, 2005.

Bechis, Marta. «Fuerzas indígenas en la política criolla del Siglo XIX», en: Goldman, Noemí y Salvatore, Ricardo (comps.) Caudillismos rioplatenses. Nuevas miradas a un viejo problema, Buenos Aires: Eudeba, 1997, págs. 293-317.

Bechis, Marta. «Fuera y dentro del confesionario. Los párrocos rurales de Buenos Aires como jueces eclesiásticos a fines del período colonial», en: Fradkin, Raúl (comp.) El poder y la vara. Estudios sobre la justicia y la construcción del Estado en el Buenos Aires rural, Buenos Aires: Prometeo, 2007, págs. 77-97.

Bustamante Vismara, José. Las escuelas de primeras letras en la campaña de Buenos Aires (18001860), Archivo Histórico «Dr. Ricardo Levene», Instituto Cultural de la Provincia de Buenos Aires, La Plata, 2007.

Bourdieu, Pierre, Campo de poder, campo intelectual y habitus de clase, Buenos Aires: Eudeba, 1999.

Canedo, Mariana. La tierra y la población en un área temprana de colonización. El Partido de los Arroyos. 1600-1850, UNMDP, Mar del Plata, 2000.

Cansanello, Carlos, «Domiciliarios y transeúntes en el proceso de formación estatal bonaerense (182032)», Entrepasados, IV, 6, Buenos Aires, 1994. 
Cansanello, Carlos. «De súbditos a ciudadanos. Los pobladores rurales bonaerenses entre el Antiguo Régimen y la Modernidad», Boletín del Instituto de Historia Argentina y Americana «Dr. Emilio Ravignani», 3a serie, 11, FFyL, UBA, Buenos Aires, 1995, págs. 113-139.

Cárcano, Ramón. 800 analfabetos. Aldeas escolares, Buenos Aires: Roldán, 1933.

Chartier, Roger. El mundo como representación, Barcelona: Gedisa, 1995.

Cignoli, Francisco. «Cirujanos y Sangradores en la costa patagónica durante el período hispano», en: Segundo Congreso de Historia Argentina y Regional, Tomo 1, Buenos Aires, Academia Nacional de la Historia, 1974, págs. 95-107.

Cortes Conde, Roberto. El Progreso argentino, Buenos Aires: Sudamericana, 1979.

Crespi Valls, Antonio. Primer centenario de la Legión Agrícola Militar. 1856-1956, Bahía Blanca, Museo Histórico, 1955.

Crespi Valls, Antonio. El Coronel Ramón Estomba. Fundador de Bahía Blanca, Bahía Blanca, Museo Histórico, 1954.

Cucuzza, Héctor Rubén. «Hacia una redefinición del estudio de la Historia Social de la Educación», en: Historia de la Educación en debate, Buenos Aires: Miño y Davila, 1996.

Darnton, Robert. «Historia de la Lectura», en: Burke Meter (ed.) Formas de hacer historia, Madrid: Alianza, 1994.

De Benedetti, Edith. «Carmen de Patagones y la enseñanza primaria: 1821-1881», en: Segundo Congreso de Historia de los Pueblos de la Provincia de Buenos Aires, Vol. 1, La Plata: [s/e], 1974.

De María, María Elina. La instrucción primaria en la Argentina (1884-1936), Buenos Aires: El Ateneo, 1936.

Diaz, Benito. Juzgados de paz de campa de la Provincia de Buenos Aires (1821-1854), UNLP, La Plata, 1959.

Donzelot, Jacques. «Espacio cerrado, trabajo y moralización», en: Castel Robert. Espacios de Poder, 2a edición, Madrid: La Piqueta, 1991.

Di Steffano, Roberto. «Abundacia de clérigos, escasez de párrocos. Las contradicciones del reclutamiento del clero secular en el Río de la Plata (1770-1840)», en: Boletín del Instituto de Historia Argentina y Americana Dr. Emilio Ravignani, 3a serie, Facultad de Filosofía y Letras, Buenos Aires, 1997-1998, págs. 33-59.

Elías, Norbert. La civilización de los padres y otros ensayos, Bogotá: Norma, 1998.

Entraigas, Raúl. El fuerte de Río Negro, Buenos Aires: Lib. Don Bosco. 1960.

Entraigas, Raúl. «La obra de Antonio de Viedma en la Patagonia», en: Segundo Congreso de Historia Argentina y Regional, ANH, Buenos Aires, 1974

Foucault, Michel. Dicho y escrito, Madrid: Gallimard, 1994.

Foucault, Michel. Arqueología del saber, Buenos Aires: Siglo XXI, 1997.

Foucault, Michel. La verdad y las formas jurídicas, Buenos Aires-Barcelona: Gedisa, 2005.

Foucault, Michel. Que es usted profesor Foucault. Sobre la Arqueología y su método, Buenos Aires: Siglo XXI, 2013.

Foucault, Michel. Vigilar y Castigar, Buenos Aires: Siglo XXI, 2014.

Fradkin, Raúl O. «Entre la ley y la práctica: la costumbre en la campaña bonaerense de la primera mitad del siglo XIX», en: Anuario del IEHS, 12, UNCPBA, Tandil, [s/f], págs. 141-156. 
Fradkin, Raúl O.¿ Y el pueblo donde está?, Contribuciones para una historia popular de la revolución de independencia en el Río de la Plata, Buenos Aires: Prometeo, 2008.

Fradkin, Raúl; Canedo, Mariana y Mateo, José (comps). Tierra, población y relaciones sociales en la campaña bonaerense (siglos XVIII y XIX), UNMDP, Mar del Plata, págs. 221-236.

Franklin, S.; Barry, M. y Pereyra, Miguel A. (comps.) Historia cultural y educación. Ensayos críticos sobre conocimiento y escolarización, Barcelona-México: Pomares, 2003.

Feire, Paulo. Pedagogía del oprimido, Buenos Aires: Siglo XXI, 1970.

Funes Derieul, Carlos. «Los primeros pedidos de solares en el cantón de Bahía Blanca. El primer escribano y el primer agrimensor», Revista Notarial, Separata 828, [s/f].

Furlong, Guillermo. «La Patagonia en la Cartografía Antigua y Moderna», en: Segundo Congreso de Historia Argentina y Regional, Academia Nacional de la Historia, Buenos Aires, 1974, págs. 139160.

Garavaglia, Juan Carlos. Poder conflicto, y relaciones sociales. El Río de la Plata, XVIII-XIX, Rosario: Homo Sapiens, 1999.

Garavaglia, Juan Carlos. Construir el Estado,inventar la nación. El Río de la Plata siglo XVIII y XIX, Buenos Aires: Prometeo, 2007.

Garavaglia, Juan Carlos y Gautreau (edits.) Mensurar la tierra, controlar el territorio. América Latina, siglos XVIII y XIX, Rosario: Protohistoria, 2011.

Garavaglia, J. C. y Moreno, J. L. (comps.). Población, sociedad, familia y migraciones en el espacio rioplatense. Siglos XVIII y XIX, Buenos Aires: Cantaro, 1993.

García Enciso, Isaías José. La gesta de Patagones, Comando en Jefe del Ejército, Año III, n. ${ }^{4}$, Dirección Estudios Históricos, Buenos Aires, 1969.

Garcia Enciso, Isaías José. La Gesta de Patagones, Buenos Aires: Eudeba, 1977.

Garcia Maese, María Angélica y Ramírez de Quattrocchio, Marta Susana. 50 años de educación Argentina y su proyeccion en Bahia Blanca. 1880-1930, Comision de Reafirmación Histórica de Bahía Blanca, Bahia Blanca: Ed. Martínez y Rodríguez, 1979.

Giddens, A. La estructura de clases en sociedades avanzadas, Madrid: Alianza Editorial, 1971.

Giroux, Henry y McLaren, Peter. Sociedad, Cultura y Educación, Madrid-Buenos Aires: Miño y Dávila, 1998.

Giroux, Henry. Los profesores como intelectuales. Hacia una pedagogía del aprendizaje, Barcelona: Paidos, 1990.

Gomez, Hernan. La Educación Común entre los argentinos. 1810-1934, Corrientes: [s/e], 1935.

González Bernardo, Pilar. «La identidad nacional en el Río de la Plata post-colonial. Continuidades y rupturas con el Antiguo Régimen», Anuario del IEHS, «Prof. Juan C. Grosso», n. ${ }^{\circ}$ 12, UNCPBA, Tandil, págs. 109-122.

Gonzalbo Aispuru, Pilar (coord..) Familia y educación en Iberoamérica. México. El Colegio de México, Centro de Estudios Históricos. 1999.

González Coll, María Mercedes. La vida en la frontera sur. Relaciones interétnicas y diversidad cultural, Bahía Blanca: Ediuns, 2000.

Goldman, Noemí. El discurso como objeto de la Historia, Buenos Aires: Hachette, 1989.

Gorelik, Adrián. Miradas sobre Buenos Aires. Historia cultural y crítica urbana, Buenos Aires: Siglo XXI, 2004. 
Gramsci, Antonio. Los intelectuales y la organización de la cultura, Buenos Aires: Nueva Visión, 1984. Gras, Mario. «La cultura en la época de Rosas», Revista del Instituto de Juan Manuel de Rosas de Investigaciones Históricas, n. ${ }^{\circ}$ 14, febrero, Buenos Aires, 1949.

Gvirtz, Silvina (comp.) Textos para pensar el día escolar. Sobre cuerpos, vestuarios, espacios, lenguajes, ritos y modos de convivencia en nuestra escuela, Buenos Aires: Santillana, 2000.

Horkheimer, M. y Adorno, T. W. Dialéctica del iluminismo, Buenos Aires: Sudamericana, 1994.

Heick, Thomas William. «Myth and meanings of intellectuals in twentieth Century British national Identity», The Journal of British Studies, Vol. 37, n. ${ }^{\circ}$ 2, April, pág. 263.

Iglesias, Evaristo. La Escuela Pública bonaerense hasta la caída de Rosas, Buenos Aires: [s/e], 1946.

Glave, Luis Miguel. «Por la palabra también se lucha. Domingo Sánchez Rebata y Manuel Lorenzo de Vidaurre en la crisis colonial peruana», Anuario IEHS, UNCPBA, Tandil, 2009, págs. 201-225.

Jara, Alvaro. «Ocupación, poblamiento y frontera», en: Jara, Álvaro (edit.) Tierras nuevas. Expansión territorial y ocupación del suelo (siglos XVI-XIX), México, Colegio de México, 1969.

Kant, Emanuel. «¿Qué es la Ilustración?», en: Filosofia de la Historia, Buenos Aires: FCE, 1941.

Katz, Ricardo Santiago. Historia de la Educación en la Provincia de Buenos Aires, Buenos Aires: Weben, 1996.

Karsz, Saúl y otros. Lectura de Althuesser, Buenos Aires: Galerna, 1970.

Korn, Alejandro. Influencias filosóficas en la evolución nacional, Buenos Aires: Solar, 1983.

Knecher, Lidia y Panaia, Marta (comps.) La mitad del país. La mujer en la sociedad argentina, Buenos Aires: CEAL, 1994.

Levene, Ricardo. Fundación de las Escuelas Públicas en la Provincia de Buenos Aires durante el gobierno escolar de Sarmiento. 1856-1861, 1875-1881, La Plata: [s/e], 1939.

Levene, Ricardo. Historia de la Provincia de Buenos Aires y formación de sus pueblos, Volumen II, La Plata: Taller de impresiones oficiales, 1941.

Levene, Ricardo, Historia de la Nación Argentina (desde los origenes hasta la organización definitiva de 1862), 2a edición, Tomo III, Buenos Aires: El Ateneo, 1947.

Manganiello, Ethel, Historia de la educación argentina, Buenos Aires: Librería del Colegio, 1953.

Maravall, José Antonio, Estado moderno y mentalidad social (siglos XV a XVII), Tomo II, Madrid: Revista de Occidente, 1972.

Maravall, José Antonio. «Sobre la revolución educativa en Castilla (siglo XVII)», Estudios de Historia del pensamiento español, Madrid: Ediciones Cultura Hispánica, 2001.

Mariluz Urquijo, José M. El Virreinato del Rio de La Plata en la época del Marqués de Aviles, Academia Nacional de la Historia, Buenos Aires, 1974.

Martínez Sierra, Ramiro. El mapa de las pampas, Tomo II, Buenos Aires: [s/e], 1975.

Martínez Sarasola, Carlos. Nuestros paisanos los indios, Buenos Aires: Emecé, 2000.

Martínez Estrada, Ezequiel. Radiografía de la Pampa, 9a edición, Buenos Aires: Losada, 1942.

Martínez Estrada, Ezequiel. Sarmiento. Meditaciones sarmientinas. Los invariantes históricos en el Facundo. Fundación Ezequiel Martínez Estrada, Rosario: Beatriz Viterbo Editorial, 2000.

Morgade, Graciela (comp.). Mujeres en la educación. Género y docencia en la Argentina. 1870-1930, Instituto de Investigaciones en Ciencias de la Educación, Buenos Aires: Miño y Dávila, 1997.

Nagel, Ernest. La estructura de la ciencia, Barcelona: Paidós, 1978. 
Navarro Floria, P. «La Patagonia en los primeros textos escolares argentinos (1862-1877)», en: Historia de la Educación, Anuario SaHe, n. ${ }^{\circ 3}, 2000-2001$.

Newland, Carlos. «La Educación elemental en Hispanoamérica desde la Independencia hasta la centralización de los sistemas educativos elementales», Hispanic American Historical Review, n. $^{\circ} 71$, 1991, págs. 335-47.

Newland, Carlos. Buenos Aires no es pampa. La educación elemental porteña 1820-1860, 1a edición, Buenos Aires: Grupo Editor Latinoamericano, 1992.

Nozzi, Emma Carmen de Patagones y las Guardia General Mitre, Museo del Carmen de Patagones, Patagones: [s/e], 1962.

Nozzi, Emma. «Carmen de Patagones y una sublevación de presidiarios», Museo Histórico Regional Municipal, Patagones: [s/e], 1967.

Nozzi, Emma. Carmen de Patagones y su proceso Educativo, Museo Histórico Regional de Patagones, Patagones: [s/e], 1971.

Paesa, Pascual R. «Milicos y fortines», Revista de la Junta de Estudios Históricos de Bahía Blanca, Volumen 4, Junta de Estudios Históricos, Bahía Blanca, 1970.

Oslak, Oscar. La formación del estado argentino. Orden, Progreso y Organización Nacional, Buenos Aires: Planeta, 1997.

Ossenbach Sauter, Gabriela. «Estado y Educación en América Latina a partir de su independencia (siglos XIX y XX)», Revista Iberoamericana de Educación, OEI, enero-abril, 1993.

Palti, Elías José; Rabinow, Paul y Stanley, Fish. Giro linguistico e historia intelectual, Universidad Nacional de Quilmes, Quilmes, 1998.

Portnoy, A. La Instrucción primaria desde 1810 hasta la sanción de la Ley 1420, Buenos Aires: [s/e], 1937.

Pro, Diego F. Anuario de Historia del Pensamiento Argentino, Tomo 1, UNCuyo, Mendoza, 1965.

Pronsato, Domingo. Luces de mi tierra, Asociación Artistas del Sur, Bahía Blanca, 1954.

Perus, Francois. «Orientalismo y occidentalismo en la Escritura de Domingo Faustino Sarmiento», Cuadernos americanos. Nueva Epoca, n. ${ }^{\circ}$ 139, UNAM, México, 2012.

Popkewitz, Thomas; Franklin Barry, M. y Pereyra, Miguel (comps.) Historia Cultural y educación. Ensayos críticos sobre conocimiento y educación, México: Pomares, 2003.

Puiggrós, Adriana. «Sujetos, disciplina y curriculum en los orígenes del sistema educativo argentino (1885-1916)», en: Historia de la Educación Argentina, Buenos Aires: Galerna, 1996.

Ramírez, Marta Susana. «La educación asistemática en la frontera sudoeste bonaerense (1833-1855)», en: Guenaga, Rosario. Estudios Socioeconómicos del sur argentino, UNS, Bahía Blanca, [s/f], págs. 43-68.

Ramírez, Marta Susana. «El plan combinado de Educación Común de Sarmiento y su aplicabilidad a la realidad socio-económica de la Provincia de Buenos Aires», en: Solar America Latina e Caribe e os Desafios de Nova Ordem Mundial, Tomo 2, PROLAM, Universidad de San Pablo, 1998, págs. 380 392.

Ramírez, Marta Susana. «Mujeres educadoras en la frontera del sudoeste pampeano (1856-1890)», $1^{\circ}$ Congreso Iberoamericano de Historia de las Mujeres y Género, UBA, Buenos Aires, 2000, en cd.

Ramírez, Marta Susana. «Reflexiones sobre la idea de Nación en la educación y la cultura bonaerense», en: Burgos, Nidia y Rigatuso, Elizabeth- La modernización del sudoeste bonaerense. Reflexiones y 
polémicas en el ámbito educativo, linguistico y literario, Archivo de la Memoria de la Universidad Nacional del Sur, Secretaría General de Comunicación y Cultura, UNS, Bahía Blanca, 2007, págs. 155-162.

Ramírez, Marta Susana. «Vinculaciones entre el Ejército de Campaña y la extensión de la educación elemental (1823-1869)», en: Cernadas de Bulnes, Mabel. Historia, política y sociedad en el sudoeste bonaerense, Bahía Blanca: Ediuns, 2011, págs. 399-409.

Ramos, Juan P. Historia de la Instrucción Primaria en la República Argentina 1810-1910, Consejo Nacional de Educación, Tomos I y II, Buenos Aires: Peuser, 1910.

Ratto, Silvia. «Relaciones interétnicas en el sur bonaerense, 1810-1830», en: Villar, Daniel. Relaciones inter-étnicas en el sur bonaerense. 1810-1830, Departamento de Humanidades, UNS, 1998.

Rebok, Elena. «Los hacendados y la frontera (1866-1874)», en: Investigaciones y Ensayos, n. ${ }^{\circ} 27, \mathrm{ANH}$, Buenos Aires, 1979, págs. 389-440.

Reyna Almandoz, Alberto. Bahía Blanca y sus Escuelas, Bahía Blanca: Panzini, 1928.

Rigamonti, Esteban. Antecedentes Históricos sobre la ciudad de Bahía Blanca, Buenos Aires: Sociedad Impresora Americana, 1950.

Roulet, Florencia. «Mujeres, rehenes y secretarios: mediadores indígenas en la frontera sur del Río de la Plata durante el período hispánico», Université de Lausane en Colonial Latin American Review, Vol 18, 3 de diciembre 2009.

Salvatore, Ricardo. «Fiestas Federales: Representaciones de la República en el Buenos Aires Rosista», Entrepasados, Vol. VI, 11, Buenos Aires, 1997.

Solari, Manuel H. Historia de la Educación Argentina, Buenos Aires: Paidos, 1976.

Suárez, Daniel. «Normalismo, profesionalismo y formación docente», La Educación. Revista Interamericana de Desarrollo Educativo, Año XXXVIII, n. ${ }^{\circ} 118$, II, 1994, págs. 285 a 300.

Silva, Hernán Asdrúbal; Godio, Guillermo; Cernada de Bulnes, Mabel; Cignetti, Ana María y Guenaga de Silva, Rosario. Bahía Blanca. Una nueva provincia y sus proyectos de capitalización, Departamento de Humanidades, UNS, Bahía Blanca, 1972.

Siebebzehner, Batia B. La universidad americana y la Ilustración. Autoridad y conocimiento en Nueva España y el Río de la Plata, Madrid: Mapfre, 1994.

Tamarit, José. Poder y educación popular, Buenos Aires: Coquena Grupo Editor, 1992.

Ternavasio, Marcela. «Nuevo régimen representativo y expansión de la frontera política. Las elecciones en el Estado de Buenos Aires:1820-1840», en: Annino, Antonio (coord.) Historia de las elecciones en Iberoamérica, siglo XIX. De la formación del espacio político nacional, México: FCE, 1995, págs. 66-105.

Vedoya, Juan Carlos. Como fue la enseñanza popular en la Argentina, Colección Esquemas Históricos, Buenos Aires: Plus Ultra, 1973.

Vieytes, Juan Hipólito. Antecedentes económicos de la Revolución de Mayo. Escritos publicados en el Semanario de Agricultura, industria y comercio. (1802-1806), Estudio Preliminar de Félix Weinberg, Buenos Aires: Raigal, 1956

Von Wright, Georg Henrik. Explicación y comprensión, Madrid: Alianza, 1994.

Weinberg, Félix. (Estudio preliminar) El Salón Literario, Buenos Aires: Hachette, 1958.

Weinberg, Félix. Vida e imagen de Sarmiento, Buenos Aires: Eudeba, 1963.

Weinberg, Félix y colaboradores. Manual de Historia de Bahía Blanca, UNS, Bahía Blanca, 1978. 
Weinberg, Félix. «Alberdi en 1843. Viaje a Europa y giro ideológico», en: América Latina. Historia y Destino. Homenaje a Leopoldo Zea, UNAM, México, 1992, págs. 429-442.

Weinberg, Félix. Esteban Echeverria. Ideólogo de la segunda Revolución, Colección Nueva Dimensión Argentina, Buenos Aires: Taurus, 2006.

Weinberg, Gregorio. Modelos educativos en la historia de América Latina, Buenos Aires: CEPAL, UNESCO, 1995.

Wasserman, Fabio. «La Generación de 1837 y el proceso de construcción de la identidad nacional argentina», en: Boletin del Instituto de Historia Argentina y Americana «Doctor Emilio Ravignani», Tercera Serie, Buenos Aires, n. ${ }^{\circ}$ 15, 1997, págs. 7-34.

Zorroaquin Becú, Ricardo. El federalismo argentino, Buenos Aires: Torre de Babel-Perrot, 1958.

Zubiaur, José Benjamín. La enseñanza práctica e industrial en la República Argentina, Buenos Aires: Lafanane, 1900.

Zuretti, Juan Carlos. Historia Eclesiástica Argentina, Buenos Aires: Huarpes, 1943.

\section{Bibliografía general}

Ansaldi, Waldo. «Notas sobre la formación de la burguesía argentina, 1780-1880», en: Florescano, Enrique. Orígenes y desarrollo de la burguesía en América Latina, Buenos Aires: Nueva Imagen, 1980.

Armus, Diego. Mundo urbano y cultura popular, Buenos Aires: Sudamericana, 1990.

Balmori, Diana y Voss Stuart, Miles Wortman. Notable family Networks in Latin America, University of Chicago, Chicago-London, 1984.

Barba, Fernando Enrique. «Progresismo y modernización en Buenos Aires: la reforma constitucional de 1873», en: Enrique M. Barba in memoriam: estudios de historia, Academia Nacional de la Historia, Buenos Aires, 1994, págs. 119 a 130.

Barba, Enrique M. Unitarismo, federalismo, rosismo, Buenos Aires: Pannedille, 1972.

Barcos, María Fernanda y Lanteri, Sol. «Tierras públcias y construcción del Estado de Buenos Aires en el siglo XIX. Las donaciones ejidales y condicionadas en una visión comparada», Boletín del Instituto de Historia Argentina y Americana «Doctor Emilio Ravignani», n. ${ }^{\circ} 38$, 3a serie, Facultad de filosofía y letras, UBA, Buenos Aires, 2013, págs. 43-74.

Banzato, Guillermo. La expansión de la frontera bonaerense. Posesión y propiedad en las tierras de Chascomus, Ranchos y Monte, Universidad de Quilmes, Quilmes, 2005.

Bazán Armando. «Visión regional de la Historia Argentina», Investigaciones y Ensayos, ANH, n. ${ }^{\circ} 49$, 1999.

Bonaudo, Marta y Pucciarelli, Alfredo. La problemática agraria. Nuevas aproximaciones, Buenos Aires: CEAL, 1993.

Bordieu, Pierre. Cosas dichas, Barcelona: Gedisa, 1993.

Burke, Peter. La Revolución historiográfica Francesa. La Escuela de los Annales: 1929-1989, Barcelona: Gedisa, 1993.

Burke, Peter. New perspectives on historical writing, Pennsylvania University, Pennsylvania, 1994. 
Cansanello, Oreste. «Sobre los orígenes de la sociedad bonaerense. Continuidades y perspectivas», Anuario IEHS, n. ${ }^{\circ}$ 12, UNCPBA, Tandil, 1997, págs. 79-89.

Chiaramonte, José Carlos. «Conceptos y lenguajes políticos en el Mundo Iberoamericano, 1750-1850», Revista de Estudios Politicos. Nueva Época, n. ${ }^{\circ}$ 140, Madrid, 2008, págs. 11-31.

Chiaramonte, Juan Carlos. «La cuestión regional en el proceso de gestación del Estado Nacional argentino. Algunos problemas de interpretación», en: Ansaldi, Waldo y Moreno, J. L. Estado y sociedad en el pensamiento nacional, Buenos Aires: Cantaro, 1989.

Chiaramonte, Juan Carlos, «Acerca del origen del Estado en el Río de la Plata», Anuario del IHES, Tandil, 1995.

Cicerchia, Ricardo. Historia de la vida privada en la Argentina, Tomos I y II, Buenos Aires: Troquel, 1999.

Balmori, Diana y Voss Stuart, Miles Wortman. Notable family Networks in Latin America, University of Chicago, Chicago-London, 1984.

Durkheim, Emile. Las reglas del método sociológico, México: [s/e], 1994.

Donzelot, Jacques. «Espacios cerrados», en: Espacios de poder, Madrid: La Piqueta, 1992, pág. 36.

Duby, Georges. La Historia continúa, Madrid: Debate, 1993.

Foucault, Michel. La verdad y las formas jurídicas, Buenos Aires: Gedisa, 2008.

Fradkin, Raul y Gelman, Jorge. «Actores intermedios y política en el mundo rural del siglo XIX», en: Anuario IEHS, n. ${ }^{\circ}$ 30, UNCPBA, Tandil, 2008.

Fragueiro, Mariano. Cuestiones argentinas, Buenos Aires: Solar Hachette, 1976.

Gelman, Jorge. «El fracaso de los sistemas coactivos de trabajo rural en Buenos Aires bajo el Rosisimo. Algunas expresiones preliminares», Revista de Indias, Vol. LIX, n. ${ }^{\circ} 215$, Madrid, 1999, págs. 133141.

Gelman, Jorge. «Derechos de propiedad, crecimiento económico y desigualdad en la región pampeana, siglos XVIII y XIX», en: Historia Agraria, n. ${ }^{\circ}$ 37, diciembre, Murcia, 2005, págs. 467-488.

Garavaglia, Juan Carlos. «Paz, orden y trabajo en la campaña. La justicia rural y los juzgados de paz en Buenos Aires.1830-52», Desarrollo económico, Vol. 37, 1997, págs. 241-262.

Garavaglia, Juan Carlos. Poder, conflicto y relaciones sociales. El Río de la Plata, XVIII-XIX, Rosario: Homo Sapiens, 1999.

Garavaglia, Juan Carlos. «Ejército y milicia. Los campesinos bonaerenses y el peso de las exigencias militares, 1810-1860», Anuario IEHS, Tandil, 2003, págs. 153-187.

Gelman, Jorge. «El mundo rural en transición», en: Goldman, Noemí. Nueva Historia Argentina, Tomo III, Buenos Aires: Sudamericana, 1998.

Goldman, Noemí. «Crisis imperial, revolución y guerra (1806-1820)», en: Goldman, Noemí. Revolución, República, Confederación (1806-1852), Nueva Historia Argentina, Tomo III, [s/1]: Sudamericana, [s/f], pág. 38 .

Goldman, Noemí. «"Revolución”, "nación” y “constitución” en el Río de la Plata: léxicos, discursos y prácticas políticas. (1810-1830)», Anuario IEHS, n. ${ }^{\circ}$ 12, UNCPBA, Tandil, 1997, págs. 101-107.

Goldman, Noemí (directora) Lenguaje y revolución. Conceptos políticos clave en el río de la Plata. 1780-1850, Buenos Aires: Prometeo, 2008.

Gorla, Carlos María. «La Frontera de Patagones en el período 1820-1840», Investigaciones y Ensayos, n. ${ }^{\circ}$ 47, ANH, Buenos Aires, 1997, pág. 409. 
Guenaga de Silva, Rosario. «Luis Piedrabuena, vanguardia argentina en la Región Austral», Boletín Histórico, n. ${ }^{\circ}$ 12, Comisión de Reafirmación Histórica, Bahía Blanca, 1983.

Goyret, José Teófilo. «Huestes, milicias y ejército regular», en: Nueva Historia de la Nación Argentina. Período español. (1600-1810), Tomo 2, ANH, Buenos Aires, 1999.

Habermas, Jurgen. Facticidad y validez, Madrid: Editorial Trotta, 1998.

Halperin Donghi, Tulio. «Revolutionary militarization in Buenos Aires, 1806-1815». Past and Present, 40, July, 1968.

Halperin Donghi, Tulio. Argentina de la Revolución de la Independencia a la Confederación Rosista, Buenos Aires: Paidos, 1972.

Halperin Donghi, Tulio. Proyecto y construcción de una nación (Argentina 1846-1880), Caracas: Ayacucho, 1980.

Halperin Donghi, Tulio. Una nación para el desierto argentino, Buenos Aires: Centro Editor de America Latina, 1997.

Harvey, Kaye. The education of desire, London: Routledge, 1999.

Hobsbawm, Eric J. Nation, nationalism since 1780, Cambridge: Cambridge University Press, 1991.

Hobsbawm, Eric J. Historia del siglo XX, Barcelona: Crítica, 1995.

Hofstede, George. Cultures and organization, Londres: Mc.Graw, 1991.

Habermas, Jurgen. La ética del discurso y la cuestión de la verdad, Buenos Aires: Paidos, 2006.

Iribarren, Claudia. «Consideraciones Generales acerca de los indios y negros en el Fuerte del Carmen», en: Estudios Socio económicos del Sur Argentino, 1, Dpto. Humanidades, UNS.

Infesta, María Elena. «Avance territorial y oferta de tierras públicas. 1810-1850», Anuario IEHS, n. ${ }^{\circ} 12$, Tandil, 1997, págs. 63-68.

Kedourie, Elie. Nacionalismo, Madrid: Centro de Estudios Constitucionales, 1988.

Le Goff, Jacques y Pierre, Nora. Hacer la Historia. Nuevos Problemas, Tomos I y II, Traducción de Jean Cabanes, Barcelona: Laia, 1985.

Levaggi, Abelardo. «La seguridad en la campaña bonaerense entre los años 1821 y 1828», Investigaciones y Ensayos, n. ${ }^{\circ}$ 20, ANH, Buenos Aires, 1977, págs. 377-410.

Mandrini, Raúl "Las fronteras y la sociedad indígena en el ámbito pampeano", en Anuario IEHS. №12. Tandil. 1997. Pp.22-34

Mandrini, Raúl. «Frontera y relaciones fronterizas en la historiografía argentino-chilena», Boletín del Instituto de Historia Argentina y Americana «Dr. Emilio Ravignani», n. ${ }^{\circ}$ 3, 3a serie, Buenos Aires, 1991, págs. 139-145.

Mandrini, Raúl (Selección) Los araucanos de las pampas en el siglo XIX, Buenos Aires: CEAL, 1984.

Mata de López, Sara Emilia. «Guerra, militarización y poder. Ejército y milicias en Salta y Jujuy. 18101816», Anuario IEHS, n. ${ }^{\circ}$ 24, UNCPBA, Tandil, 2009.

Mendieta, Eduardo. «La alterizaciÓn del Otro: crítica de la razón latinoamericana», Cuadernos Americanos. Nueva Época, n. ${ }^{\circ}$ 62, México, 1997, págs. 76-86.

Metz, Charles. «Imágenes y pedagogía», en: Durand, J. Análisis de las Imágenes, Buenos Aires: [s/e], 1974.

Morales Padrón, Francisco. «Historia General de América», en: Manual de Historia Universal, Madrid: Espasa Calpe, 1975. 
Moreyra, Beatriz I. y Mallo, Silvia (comps.) Pensar y construir los grupos sociales. Actores, prácticas y representaciones. Córdoba y Buenos Aires, siglos XVI-XX, Centro de Estudios Históricos «Carlos Segretti», La Plata, 2009.

Myers, Jorge. Orden y virtud. El discurso republicano del regimen rosista, Universidad Nacional de Quilmes, Bernal, 1995.

Nagel, Ernest. La Estructura de la ciencia, [s/1]: Paidós, 1978.

Nellar, Fued G. (director) Reseña Histórica y orgánica del Ejército argentino, Volumen 613, Círculo Militar, Buenos Aires, 1971.

Nieto, C. Saber, sentir y pensar, Madrid: Debate, 1997.

Páez, Darío. «Cultura y conocimiento de sí en España e Iberoamérica», en: Nieto, C. Saber, sentir y pensar, Madrid: Debate, 1997.

Páez, Darío y Gonzalez, José Luis. «Culture and social psychology», Psicothema, Volumen 12, University of the Basque Country. University of Burgos, 2000.

Quijada, Mónica. «De La Nación en el imaginario Hispano Americano del siglo XIX», en: Guerra, François Xavier y Quijada, Mónica (eds.). Imaginar la Nación, AHILA, Cuadernos de Historia Latinoamericana, Hamburg: [s/e], 1994.

Ratto, Silvia en Mandrini, Raúl J. Relaciones interétnicas en el Sur bonaerense 1810-1830, UNSUNCPBA, Bahía Blanca, 1998.

Ratto, Silvia «Los indios y la Revolución en el Río de la Plata. El proceso independentista entre los indígenas soberanos de Pampa y Chaco», en: Bragoni, Beatriz y Mata, Sara (comps.) Entre la colonia y la República, Buenos Aires: Prometeo, 2008.

Ratto, Héctor Raúl. Carta del litoral bonaerense comprendido entre el rio Colorado y Negro, Publicaciones del Instituto de Investigaciones Geográficas de la Facultad de Filosofia y Letras, Serie B. Documentos Cartográficos, Buenos Aires: Peuser, 1930.

Sánchez Ceschi, Eduardo. Crónica histórica de Carmen de Patagones entre los años 1852-1855, Buenos Aires: Tor, 1937.

Salvatore, Ricardo. «Reclutamiento militar, disciplinamiento y proletarización en la era de Rosas», en: Boletín del Instituto de Historia Argentina y Americana «Dr. Emilio Ravignani», Tercera Serie, n. ${ }^{\circ} 5$, Buenos Aires, 1992, págs. 25-47.

Salvatore, Ricardo. Subalternos, derechos y justicia penal. Ensayos de Historia social y cultural argentina 1829-1940, Mexico: Gedisa, 2010.

Shumway, Nicholas. La invención de la Argentina, Buenos Aires: Emece, 1993.

Silva, Hernán Asdrúbal. «Proceso colonizador en la región Patagónica en la etapa Virreinal», I Coloquio Universitario sobre colonización en la América Hispánica, Tucumán, 1982.

Stone, Lawrence. «La Historia y las ciencias sociales en el siglo XX», El Pasado y el Presente, México: FCE, 1986.

Tarragó, Myriam Noemí (dir.) «Los pueblos originarios y la conquista», en: Suriano, Juan (coord. gral.) Nueva Historia Argentina, Tomo 1, Buenos Aires: Sudamericana, 2000.

Turner, Frederick Jackson. The frontier in American History, New York: [s/e], 1958.

Van Young, Eric. «Mexican Rural History since Chevallier: the historiography of de colonial haciencia», Latin American Research Review, Estados Unidos, 1983, 18:3, págs. 5-61. 
Van Young, Eric. «Haciendo historia regional. Consideraciones metodológicas y teóricas», Anuario IHES, UNCPBA, Tandil, 1987.

Villar, Daniel y Bustos, Jorge. «Indios y blancos, sal y ganado mas allá de la frontera, Patagones. 18201830», Anuario IHES, Vol. VIII, UNCPBA, Tandil, [s/f].

Zeberio, Blanca; Bjerg, María y Otero, Hernán (comps.) Reproducción social y sistemas de herencia en una perspectiva comparada. Europa y los paises nuevos (siglos XVIII al XX), Instituto de Estudios Históricos sociales, con el apoyo de l'Ecole d' Hautes Ètudes en Sciences Sociales e Irep, Tandil, 1998.

Zúñiga, Jean Paul. «Clan, parentela, familia, individuo: qué métodos y niveles de análisis», Anuario IHES, ${ }^{\circ}{ }^{\circ} 15$, UNCPBA, Tandil, 2000. 


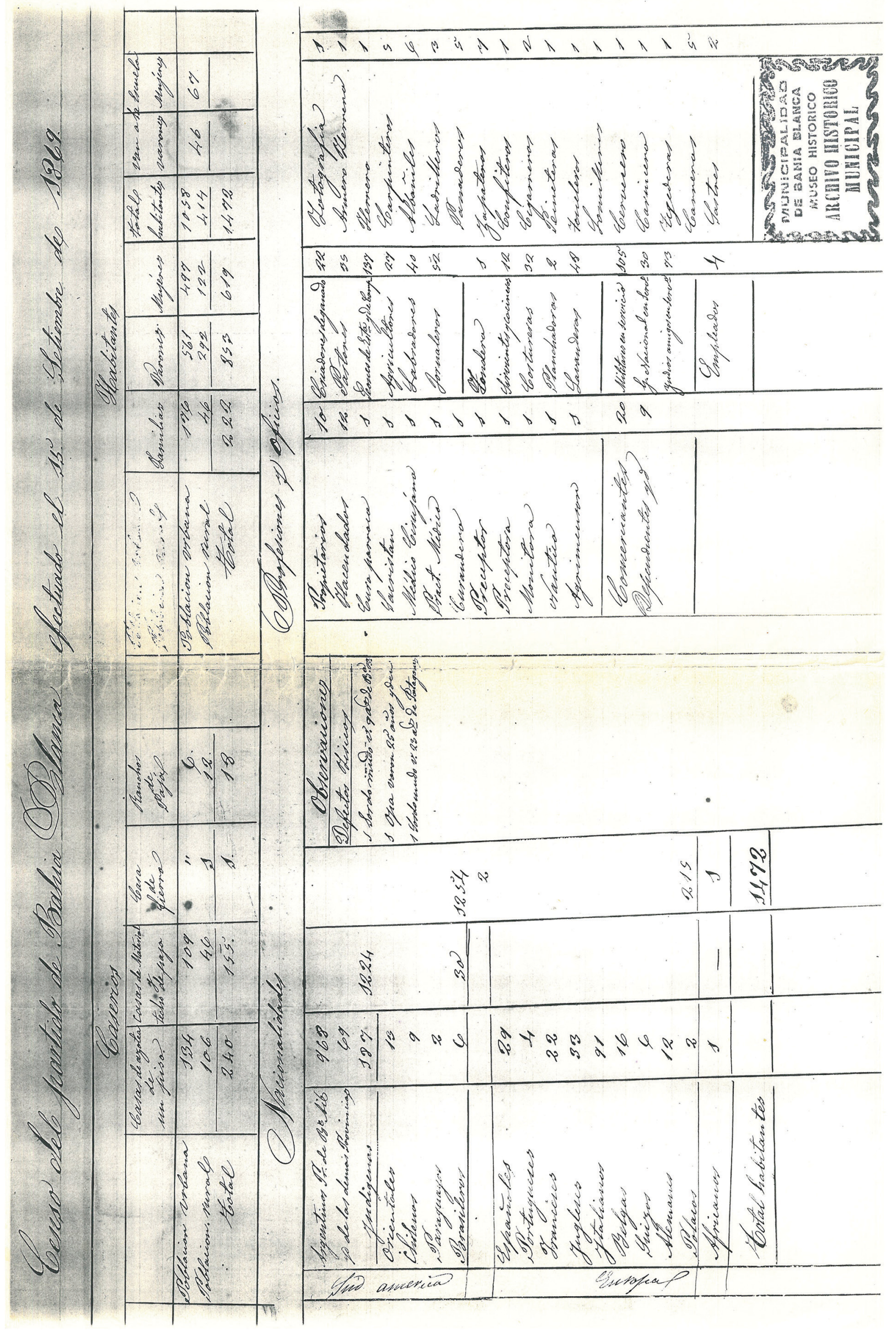


$\Theta$

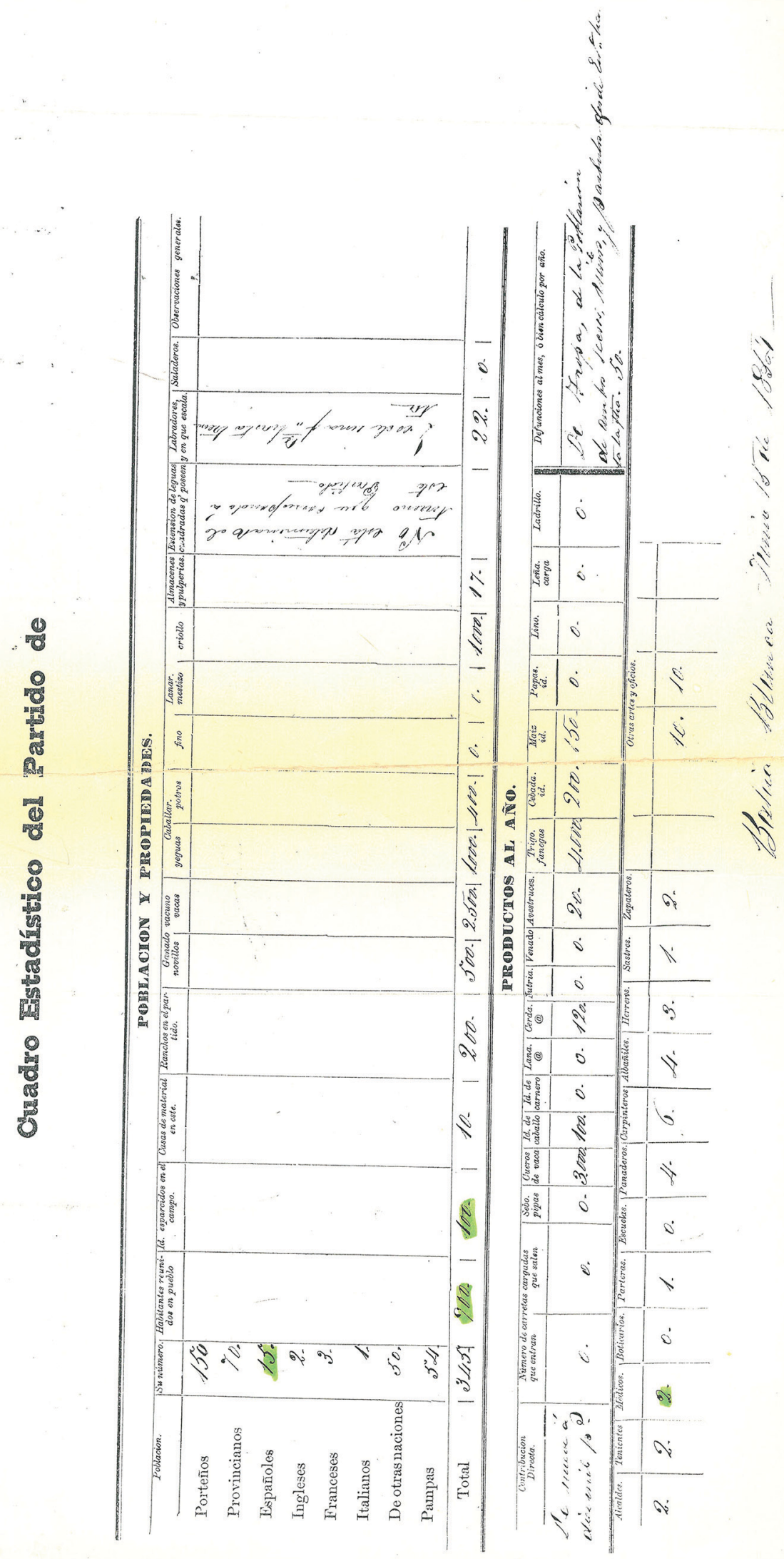

